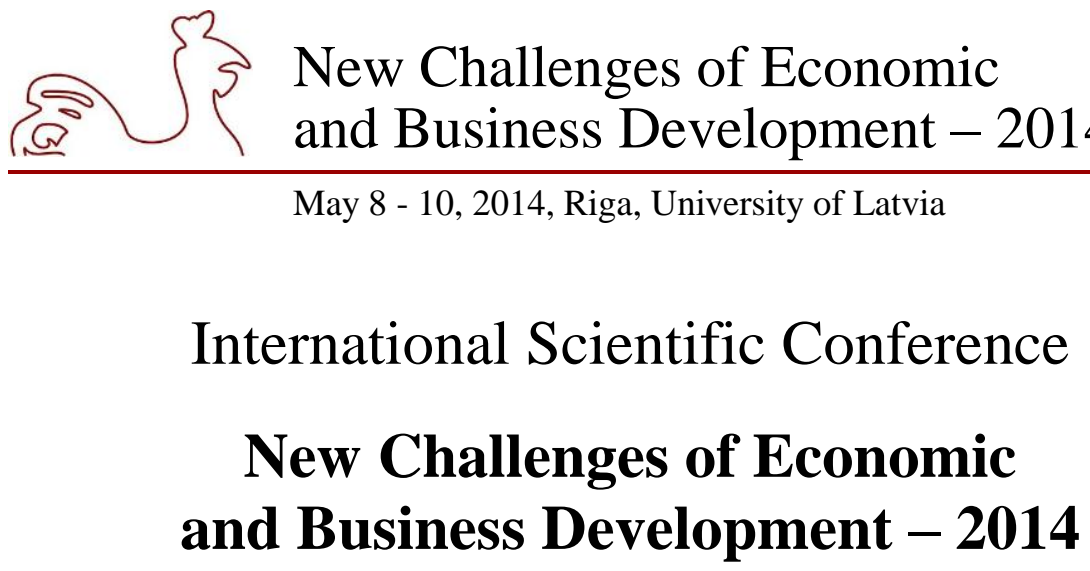

\title{
ABSTRACTS OF REPORTS
}

Organised by Faculty of Economics and Management, University of Latvia in cooperation with

Latvian European Community Studies Association

Institut CEDIMES - Lettonie

Econometrists Association of Latvia

Latvian Information and Communications Technology Association

Association of Statisticians of Latvia

Baltic Sea Region University Network (BSRUN)

Conference is supported by

Wellton Hotel Group and University of Latvia, Faculty of Economics and Management

May 8-10, 2014

Riga, University of Latvia

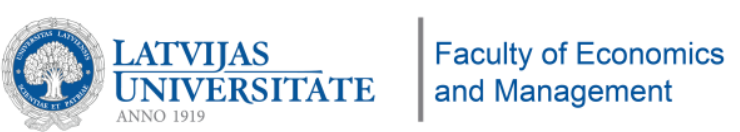


International Scientific Conference "New Challenges of Economic and Business Development - 2014": Riga, Latvia, May 8-10, 2014. Abstracts of Reports. Riga: University of Latvia, 2014, 154 p.

\section{Conference Scientific Committee}

Jean D. Avenel, Dr., Professor, University Paris XII (France)

Ludmila Bandeviča, Dr. habil. oec., Professor, University of Latvia

Anda Batraga, Dr. oec., Associate Professor, University of Latvia

Howard R. Balanoff, Dr., Professor,

Texas State University (USA)

Inta Brūna, Dr. oec., Professor, University of Latvia

Gaļina Cernova, Dr. habil. oec., Professor, Saint Petersburg State University (Russia)

Rasa Daugèliene, Dr., Associate Professor, Kaunas University of Technology (Lithuania)

Mindaugas Dapkus, Dr., Associate Professor, Vytautas Magnus University (Lithuania)

Džineta Dimante, Dr. oec., Associate Professor, University of Latvia (co-ordinator)

Elena Dubra, Dr. oec., Professor, University of Latvia

Simon Grima, Dr., Lecturer, University of Malta

Toomas Haldma, Dr., Professor, Tartu University (Estonia)

Arto Haveri, Dr., Professor, Tampere University (Finland)

Kari Hypponen, University of Turku, Finland Baltic Sea Region University Network (BSRUN)

Gundars Kaupins, Dr., Professor, Boise University (USA)

Lücija Kavale, Dr. oec., Professor, University of Latvia

Juris Krūmiňs, Dr. habil. oec, Professor, University of Latvia

Natalija Kuznecova, Dr. habil. oec., Professor, Saint Petersburg State University (Russia)

Karl-Heinz Leitner, Dr., AIT Austrian Institute of Technology GmbH (Germany)

Per Lind, Dr., Professor, Uppsala University (Sweden)

Tatjana Muravska, Dr. oec., Professor, University of Latvia

Shin'ya Nagasawa, Dr., Professor, Waseda University (Japan)

Joseph Neuert, Dr., Professor, University of Applied Sciences Kufstein (Austria)

Tiiu Paas, Dr., Professor, Tartu University (Estonia)

Gunnar Prause, Dr., Professor,

Tallinn University of Technology (Estonia)

Jānis Priede, Dr. oec., Assistant Professor, University of Latvia

Māris Purgailis, Dr. oec., Professor, University of Latvia

Alari Purju, Dr., Professor, Tallinn University of Technology (Estonia)

Layout and compilation: Sandra Neidere, Ludis Neiders Logo: Mārtiňš Danusēvičs

Cover design: Andra Liepinga

ISBN 978-9984-45-835-9
Inna Romānova, Dr. oec., Assistant Professor, University of Latvia

Uldis Rozevskis, Dr. oec., Associate Professor, University of Latvia

Ramona Rupeika-Apoga, Dr. oec., Associate Professor, University of Latvia

Eric Schoop, Dr., Professor,

Dresden Technical University (Germany)

Bruno Sergi, Dr., Professor, Messina University (Italy)

Rasa Snapstiene, Dr., Associate Professor, Kaunas University of Technology (Lithuania)

Biruta Sloka, Dr. oec., Professor, University of Latvia

Aija van der Steina, Dr. oec., Senior Researcher, University of Latvia

Arild Saether, Professor, Agder University (Norway)

Baiba Šavrina, Dr. oec., Professor, University of Latvia

Ligita Šmanskienè, Dr., Professor, Klaipeda University (Lithuania)

Roberts Škapars, Dr. oec., Professor, University of Latvia Daina Škiltere, Dr. oec., Professor, University of Latvia

Érika Šumilo, Dr. oec., Professor, University of Latvia Maaja Vadi, Dr., Professor, Tartu University (Estonia)

Inga Vilka, Dr. oec., Associate Professor, University of Latvia

Inesa Vorončuka, Dr. oec., Professor, University of Latvia

Elvīra Zelgalve, Dr. oec., Professor, University of Latvia

Conference Organizing Committee

Anda Batraga, University of Latvia (Social programme)

Kristīne Bērzinga, University of Latvia (Social programme)

Kaspars Čikste, University of Latvia (Finances, sponsoring)

Mārtiņš Danusēvičs, University of Latvia (IT support, design)

Džineta Dimante, University of Latvia (Coordination of Committees work)

Ella Jākobsone, University of Latvia (Correspondence, registration)

Ināra Kantāne, University of Latvia (IT support)

Inese Lubāne, University of Latvia (Invoices, invitations, confirmations)

Biruta Sloka, University of Latvia (Coordination of conference)

Aija van der Steina, University of Latvia (Coordination of conference)

Rita $\check{Z} \boldsymbol{u k a}$, University of Latvia (Conference webpage design and update) 


\section{2 $\{3$ New Challenges of Economic and Business Development - 2014}

May 8 - 10, 2014, Riga, University of Latvia

\section{REVIEWERS}

Extended abstracts and papers submitted to the international scientific conference New Challenges of Economic and Business Development - 2014 have been double-blind reviewed by the following reviewers:

Dr. habil. Ludmila Bandeviča, University of Latvia, Latvia

Dr. Signe Bälinga, University of Latvia, Latvia

Dr. Anda Batraga, University of Latvia, Latvia

Dr. Ilona Baumane-Vìtolina, University of Latvia, Latvia

Dr. Juris Benders, University of Latvia, Latvia

Dr. Atis Bērzinšs, University of Latvia, Latvia

Dr. Edgars Brēksis, University of Latvia, Latvia

Dr. Ieva Brence, RISEBA, Latvia

Dr. Jānis Brizga, NGO Green Liberty, Latvia

Dr. Inga Būmane, University of Latvia, Latvia

Dr. Andrejs Cekuls, University of Latvia, Latvia

Dr. Inta Ciemina, University of Latvia, Latvia

Dr. Vadims Danovičs, University of Latvia, Latvia

Dr. Dagnija Dan̦ēviča, University of Latvia, Latvia

Dr. Mindaugas Dapkus, Vytautas Magnus University, Lithuania

Dr. Rasa Daugeliene, Kaunas University of Technology, Lithuania

Dr. Alexandrina Deacanu, Bucharest University of Economic Studies, Romania

Dr. Andris Deniňš, University of Latvia, Latvia

Dr. Juris Dreifelds, Brock University, Canada

Dr. Elena Dubra, University of Latvia, Latvia

Dr. Margarita Dunska, University of Latvia, Latvia

Dr. Arto Haveri, Tampere University, Finland

Dr. Jeff Jarvis, Monash University, Australia

Dr. Sandra Jēkabsone, University of Latvia, Latvia

Dr. Henrijs Kalkis, University of Latvia, Latvia

Dr. Ināra Kantāne, University of Latvia, Latvia

Dr. Edgars Kasalis, University of Latvia, Latvia

Dr. Gundars Kaupins, Boise University, USA

Dr. Viesturs Pauls-Karnups, University of Latvia, Latvia

Dr. Lücija Kavale, University of Latvia
Dr. habil. Juris Krūmiņšs, University of Latvia

Dr. Karl-Heinz Leitner, Austrian Institute of Technology, Austria

Dr. Per Lind, Uppsala University, Sweden

Dr. Tatjana Muravska, University of Latvia, Latvia

Dr. Ilze Medne, University of Latvia, Latvia

Dr. Jānis Priede, University of Latvia, Latvia

Dr. Māris Purgailis, University of Latvia, Latvia

Dr. Alari Purju, Tallinn University of Technology, Estonia

Dr. Kārlis Purmalis, University of Latvia, Latvia

Dr. Inna Romānova, University of Latvia, Latvia

Dr. Uldis Rozevskis, University of Latvia, Latvia

Dr. Ramona Rupeika-Apoga, University of Latvia, Latvia

Dr. Svetlana Saksonova, University of Latvia, Latvia

Dr. Biruta Sloka, University of Latvia, Latvia

Dr. Aija van der Steina, University of Latvia, Latvia

Dr. Baiba Šavrina, University of Latvia, Latvia

Dr. Ligita Šimanskiené, Klaipeda University, Lithuania

Dr. Roberts $\breve{S}$ kapars, University of Latvia, Latvia

Dr. Daina Škiltere, University of Latvia, Latvia

Dr. Ruta Šneidere, University of Latvia, Latvia

Dr. Erika Šumilo, University of Latvia, Latvia

Dr. Loreta Valanciene, Kaunas University of Technology, Lithuania

Dr. Inga Vilka, University of Latvia, Latvia

Dr. Anastasija Vilcinga, Latvia University of Agriculture, Latvia

Dr. Craig Webster, University of Nicosia, Cyprus

Dr. Inesa Vorončuka, University of Latvia, Latvia

Dr. Elvīra Zelgalve, University of Latvia, Latvia 


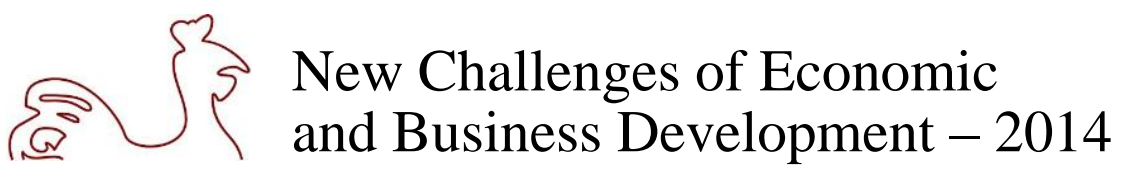

May 8 - 10, 2014, Riga, University of Latvia

\section{CONTENTS}

Reviewers

Inese Aleksejeva. Subjective and Objective Knowledge of Latvian Consumers about Genetically Modified Organisms

Signe Allena. Tendencies of Electricity Production and Consumption in the Baltic Sea Region ...... 9

Daira Barānova. Youth Unemployment Problems in European Union and Latvia ......................... 11

Kristīne Bērzina, Ilze Medne. Latvian Tourism Brand Awareness in German Tourism Market .... 13

Helmut Birnleitner. The Influence of Macro-Environmental Factors to the Decision

Process of Selecting a Country for Expansion Strategies

Leszek Bohdanowicz. Managerial Hegemony and Supervisory Board Activity:

Evidence from Polish Listed Companies

Lìga Braslina, Kaspars Vīksne, Anda Batraga. Comparative Analysis

of Innovation Process Approaches

Inta Brūna, Inta Millere. The Impact of the New Accounting Directive (2013/34/EU)

on the Normative Regulations of the Republic of Latvia

Ilze Buligina, Biruta Sloka. Approaches by Public Administrations to Promote

VET Internationalisation

Svetlana M. Bychkova, Elena Y. Itygilova. Purposes of Financial Statements and Auditing:

Methodological Problems of Criteria Definition and Classification of Financial Statements

Distortions Justification

Qiling Chen, Xiaosong Zheng. International Joint Venture Performance Measurement in China: An Exploratory Study of Sino-Nordic Joint Ventures

Aleksandrs Dahs. Measuring the Impact of Spatial Factors in Regional Demographic

Development of Latvia

Milda Damkuvienè, Sigitas Balčiūnas, Evandželina Petukienè. Client Perceived

Participation Value: Conjoint Analysis

Mārtiņš Danusēvičs, Signe Krūmiņa, Džūilija Voznesenska. Spatial Aspects

of Retail Planning in Riga

Dagnija Dan̄eviča, Ieva Aizsila, Roberts Ikaunieks. Audit Fee Setting Associated Risk Factors .... 35

Mindaugas Dapkus. L'Hypothèse Du Mensonge Macroéconomique ..................................... 37

Rasa Daugèliene. The Nature of Trade Relations between Lithuania and Russia:

Investigation on Application of Trade Barriers in Period of 2007 - 2012

Tomasz Dorożyński, Janusz Świerkocki, Wojciech Urbaniak. The Role of Incentives

in Attracting FDI to the Region of Lodz

Elena Dubra, Kristaps Soms. The Impact of EU Policy on Social Development of Latvia .... 43

Ivita Faituša. Internal Audit System Changes in Local Governments of Latvia ...................... 45

Christiane Gaul. International Franchise Partner Selection Model ........................................ 47

Jolita Greblikaite. Ethical Codes in Lithuanian Small and Medium-Sized Enterprises:

Problems and Solutions

Simon Grima, Inna Romānova, Frank Bezzina, Frank Chetcuti Dimech. Alternative

Investment Fund Managers Directive and Its Impact on Malta's Financial Service Industry 51

Piotr Grudowski, Malgorzata Wisniewska. Assessment of Preparedness

to Lean Six Sigma Projects in Small and Medium-Sized Enterprises 
May 8 - 10, 2014, Riga, University of Latvia

Ksenija Ijevleva, Ilja Arefjevs. Web-Based Resources as Financial Literacy

Improvement Tool

Valentyna Ilgenayeva, Hans Elbeshausen. Teaching and Learning in, with

and Through Entrepreneurship: Lessons Learned From an Experiment

in Socio-Cultural Entrepreneurship Education

Svetlana Jesilgevska. Difficulties with Innovation Statistics: Some Key Issues ...................... 59

Inga Jëkabsone, Biruta Sloka. The Methodology of Measurement of Objective

Well-Being in Municipalities: Case of Latvia

Madara Kairiša. The Role of Organizational Culture in Innovative Performance

of Small and Medium-Sized Knowledge-Intensive Companies in the Baltic States

Rasa Kanapickiene, Arvydas Kanapickas. Evaluation of Wind Energy Investment Project .. 65

Lücija Kavale. The Influence of Tax Earmarking on the Fiscal Policy ..................................... 67

Laura Keršule, Biruta Sloka. Personnel Motivation Factor Analysis .....................................69 69

Marija Krumina. Determinants of Early-Stage Entrepreneurship in Latvia .......................... 71

Eriks Lingeberzins. Use of Hofstede Dimensions in Multi-Cultural Tourism Product

Quality Evaluation

Maria Makarova. Economic Growth in Firm Investment Policy Model

Accounting for Employees Learning

Rosvydas Marcinkevičius, Rasa Kanapickienè. Possibilities to Apply Bankruptcy

Prediction Models in Lithuanian Companies of Construction and Transport

Susanna Minder. Market-Oriented External Human Resource Marketing in Germany -

Overview of Existing Experience and Actual Situation in Germany

Ieva Moore. Exploring the Concept of Cultural and Creative Industries …............................ 81

Leila Neimane. NIMBY Effect in Environmental Impact Assessment ................................. 83

Monika Nikitina-Kalamäe, Natalja Gurvitš. E-Annual Reporting of the Estonia

TOP100 Companies for the Years 2007-2012

Nicholas Olenev. Identification of the Uzawa-Lucas Model for World Economy ................... 87

Rita Ozolina. The Laeken Indicator: Regional Cohesion (Dispersion of Regional

Employment Rates)

Tiiu Paas, Mart Kaska. Cross-Border Labour Mobility as a New Challenge

for Economic and Business Development

Tatiana Papiashvili. Georgia: Entrepreneurial Economy - Entrepreneurship Education ........ 93

Leonardo Pataccini. Financialization in Transition: A Critical Analysis from

the Perspective of International Political Economy

Olga Rajevska. Latvian Pension System: Calibration by Crisis ............................................... 97

Detlev Remy, Wolf Magnus Gerstkamp, Evelyn Ebiner, Kristīne Bērzina,

Ingrīda Millere, Linda Medne. Impact of New Developments in Distribution

on the Hotel Industry: A Case of Latvian Hotels

Ramona Rupeika-Apoga, Edgars Brekis. Enhancement of Study Course

"International Finance" as a Part of the Bologna Process

Ramona Rupeika-Apoga, Roberts Nedovis. Foreign Exchange Risk Management

in Non-Financial Companies: Case of the Baltic States

Didzis Rutitis, Anda Batraga. Paid Health Care Service Provision in Latvia -

Customer Survey Results

Contents 
May 8 - 10, 2014, Riga, University of Latvia

Alen Sacek. Due Diligence in Mergers and Acquisitions in Emerging Markets -

Evaluated Risk Factors from the Academic and Practical View

Timurs Safiulins. Labour Market as a Prerequisite for the Formation of the

Knowledge-Based Start-Ups

Svetlana Saksonova. Analyzing Secondary Professional Education Systems

in Kurzeme and Zemgale Regions: Institutions and Labor Market Demand

Tom Sander, Teh Phoey Lee. SmartPLS for the Human Resources Field to Evaluate a Model ... 112

Barbara Scharrer. Does Cultural Background Affect Compliant Behaviour in China? ........ 114

Iryna Semehen. Opportunities and Treats for Conducting Money Laundering Risk

Assessment Methodology in Banks

Jolita Sinkiene, Rasa Snapstiene, Ruta Petrauskiene. Assessment and Recognition

of Competencies Acquired in Non-Formal Education: Perspective and Practice

of Lithuanian Universities

Ronalds Skulme, Valerijs Praude. Online Marketing Tools Usefulness in Managing

Customer Purchase Decision Process

Biruta Sloka, Valdis Avotiņš, Ināra Kantāne, Elita Jermolajeva, Natālija Jarohnoviča,

Anete Brauča. Performance Expectations of Entrepreneur's in Business Start ...................... 122

Gordana Spejic. Acceptance through Willingness and Readiness in Change Projects .......... 124

Natalia Spiridonova. Changes in Oil Prices and Global Economic Growth ......................... 126

Santa Sproge-Rimša. Export Potential Determination of Higher Education

of Three Universities of Baltic States in the Aspect of "New Competitiveness" ................... 128

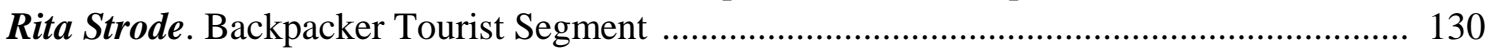

Yulia Stukalina. Strategic Management of Modern Higher Education Institutions ............... 132

Jelena Šalkovska, Elīna Ogsta. Quantitative and Qualitative Measurement Methods

of Companies' Marketing Efficiency .................................................................................... 134

Marion Tenge. Satisfaction of Economic Needs on Public Social Software Platforms -

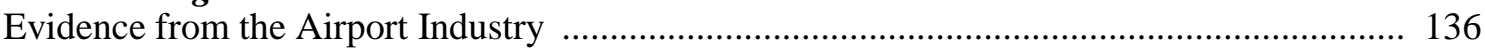

Maria Tissen. The Most Demanded Ratios of Financial Analysis at the

Enterprises of Latvia

Dan Ţop. Prevention Et Lutte Contre Le Travail Non Declare, Une Provocation

Globale Dans U.E.

Jurate Valuckiene, Jurgita Bersenaite, Rigita Tijunaitiene. Customer Motives

to Participate as Presumption for Service Co-Creation

Inesa Voronchuk, Olga Starineca. Human Resource Recruitment and Selection

Approaches in Public Sector: Case of Latvia

Malgorzata Wiśniewska, Piotr Grudowski. The High Quality Business School

Academic Teacher of the $21^{\text {st }}$ Century - Polish Students' Perspective

Hanjun Yin, Xiaosong Zheng. International Joint Venture Performance Measurement and

Development Strategy in China - An Exploratory Study of Sino-Swedish Joint Ventures

Xiaosong Zheng, Jaan Alver. Perspectives on Governmental Management

Accounting in China

Anna Zhigalova. Market Dynamics in Consumer Segmentation: Modelling Framework

Anna Ždanoviča. The Impact of Socioeconomic Reforms on the Work Incentives in Latvia 153 


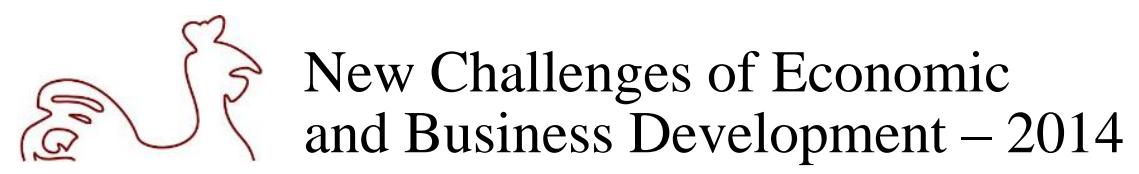

May 8 - 10, 2014, Riga, University of Latvia

\title{
SUBJECTIVE AND OBJECTIVE KNOWLEDGE OF LATVIAN CONSUMERS ABOUT GENETICALLY MODIFIED ORGANISMS
}

\author{
Inese Aleksejeva, University of Latvia, Latvia ${ }^{1}$
}

Key words: consumer attitude, knowledge, genetically modified

JEL codes: I21, M31, Q16

\section{Extended abstract}

In Latvia matter of genetically modified organisms for some groups of the consumers is of high interest but for some of them - even very sensitive. Latvia is one of the most conservative countries in the world regarding products obtained with the help of genetic modification and this attitude is justified on fear which is based on some knowledge and subjective perception that genetically modified organisms are dangerous and risky.

In the list of the articles and literature on consumers' attitude and acceptance of genetically modified organisms the significant difference is observable concerning the impact of the consumers' knowledge on such attitude or acceptance. One of the explanations for such difference could be the method of the measurement of the consumers' knowledge and therefore it is important to analyse both objective (what exactly the consumer knows), and subjective (what the consumer thinks he knows) knowledge.

The aim of this article is to present the initial results obtained during the survey of Latvian consumers to elicit subjective and objective knowledge about genetically modified organisms and genetic modification. The main tasks are to provide the review of the literature regarding relationship between consumers' knowledge and acceptance of genetically modified organisms and to develop the core questions to elicit the objective knowledge of Latvian consumers on genetically modified organisms. This paper addresses the key issues that allow to measure the level of Latvian consumers' knowledge about domain of interest. The questions are elaborated in cooperation with Latvian scientists in the field of biology and further will be incorporated in the survey on Latvian consumers' attitude regarding use of genetically modified organisms in food production and other industries where also relationship between level of the consumers' knowledge and attitude to or acceptance of genetically modified products will be evaluated.

\section{Bibliography}

Brucks, M., 1985. The Effects of Product Class Knowledge on Information Search Behavior. Journal of Consumer Research, 12(6), pp. 1-16.

Christoph, I.B., Bruhn, M. \& Roosen, J., 2008. Knowledge, attitudes towards and acceptability of genetic modification in Germany. Appetite 51 (1), pp. 58-68.

Durant, R.F. \& Legge, J.S., 2005. Public Opinion, Risk Perceptions, and Genetically Modified Food Regulatory Policy. European Union Politics, 6 (2), pp. 181-200.

Ganiere, P., Chern, W. S., \& Hahn, D., 2006. A continuum of consumer attitudes towards genetically modified foods in the US. Journal of Agricultural and Resource Economics, 31(1), pp. 129-149.

Ghasemi, S., Karami, E. \& Azadi, H., 2013. Knowledge, attitudes and behavioral intentions of agricultural professionals toward genetically modified (GM) foods: a case study in Southwest Iran. Science and Engineering Ethics, 19(3), pp. 1201-1227.

${ }^{1}$ Corresponding author - e-mail address: Aleksejeva.Inese@ gmail.com, phone number: +371 29675493

Inese Aleksejeva 


\section{$2\left\{\begin{array}{l}3 \\ 5\end{array}\right.$ New Challenges of Economic and Business Development - 2014}

May 8 - 10, 2014, Riga, University of Latvia

Hoban, T. J., 1997. Consumer acceptance of biotechnology: An international perspective. Nature Biotechnology, 15, pp. 232-234.

Hoban, T., \& Katic, L., 1998. American consumer views on biotechnology. Cereal Foods World, 43(1), pp. 20-22.

House, L., Lusk, J., Jaeger, S., Traill, W. B., Moore, M., Valli, C., Morrow, B. \& Yee, W.M.S., 2004. Objective and Subjective Knowledge: Impacts on Consumer Demand for Genetically Modified Foods in the United States and the European Union. AgBioForum, 7(3), pp. 113-123.

Miller, H.I. and Conko, G., 2000. The science of biotech meets the politics of global regulation. Issues in Science and Technology, 17(1), pp. 47-54.

Onyango, B., Govindasamy, R., Hallman, W., Jang H.M., \& Puduri, V. S., 2004. Consumer acceptance of genetically modified foods in Korea: Factor and cluster analysis. Working Paper No. WP-1104-015. New Jersey: Food Policy Institute, Rutgers University.

Rodríguez-Entrena, M., \& Salazar-Ordóñez, M., 2013. Influence of scientific-technical literacy on consumers' behavioural intentions regarding new food. Appetite., 60(1), pp. 193-202.

Scholderer, J., \& Frewer, L. J., 2003. The biotechnology communication paradox: Experimental evidence and the need for a new strategy. Journal of Consumer Policy, 26, pp. 125-157.

Park, C. W. \& Lessig, V. P., 1981. Familiarity and its Impacts on Consumer Decision Biases and Heuristics. Journal of Consumer Research, 8 (9), pp. 223-230.

Pew Initiative on Food and Biotechnology, 2001. Pew initiative on food and biotechnology finds public opinion about genetically modified foods 'up for grabs. Washington, DC: Pew Charitable Trusts. [Online] Available at: http://www.pewtrusts.com.

Xiaoyong, Z., Jikun, H., Huanguang, Q. \& Zhurong, B., 2010. A consumer segmentation study with regards to genetically modified food in urban China. Food Policy, 35 (5), pp. 456-462. 


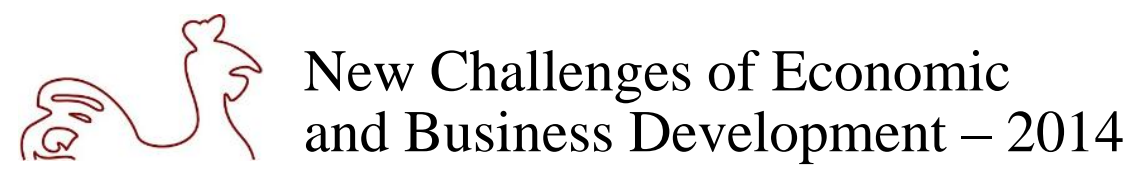

May 8 - 10, 2014, Riga, University of Latvia

\title{
TENDENCIES OF ELECTRICITY PRODUCTION AND CONSUMPTION IN THE BALTIC SEA REGION
}

\author{
Signe Allena, University of Latvia ${ }^{2}$
}

Key words: electricity production, consumption, statistical analysis

JEL codes: O13, Q41, Q42, Q48

The number of studies in field of energy in Europe has increased recently since energy, particularly electricity is important for each country and for each national economy especially now when energy consumption in general increases. Several research in monitoring the energy supply in the Baltic Sea region (BSR) has been performed and conclusions drawn for future activities (Streimikiene, 2007). Coexistence of electricity, TEP and TGC markets in the BSR is on regular research agenda likewise (Hindsberger, et al, 2003). There are several tries and evaluation of those tries to make electricity production greener (Raada, et al, 2012). Wind energy is used in many countries, efficiency of it's use and challenges are assessed by many researchers in many countries, especially a lot of investigations have been performed in Lithuania (Katinas, et al, 2009). Renewable generation and electricity prices are compared in several counties (Würzburg, et al, 2013) but only few of researches are focused on importance of cooperation in energy sector in the BSR (Streimikiene, 2007).

Although in many cases is assumed that the Baltic Sea Region comprises 11 nations, in this paper is being analysed so-called European Union BSR that counts 85 million inhabitants (17 percent of EU population) and eight countries - Sweden, Denmark, Estonia, Finland, Germany, Latvia, Lithuania and Poland (European Union EU Strategy for the Baltic Sea Region, 2009). BSR differs significantly by climatic, economic and social factors but continuous electricity supply is one of the key factors to further development of any country. As electricity cannot be stored, it needs to be delivered in the moment it is being demanded and in situation when demand of electricity is continuously increasing while fossil resources are becoming less, electricity supply becomes an important national issue for each country. Taking into account these aspects, the cooperation between countries are extremely important particularly in situations when state is unable to ensure sufficient power supply and cross-border cooperation is often the only opportunity to ensure sufficient energy supply. In such a sensitive area as energy security, countries should be able to develop different models of cooperation in order to reduce the risks for security of supply. As concluded in the study, cooperation between BSR states is very strong - there are created many different forms of cooperation starting from strategies and plans to political forums, programmes and power market. Author believes that this kind of cooperation is absolutely necessary for the stability and development of the country and further studies should be developed to determine the clear impact of cross-border cooperation and whether cooperation forms which are applied in BSR are most effective.

While stocks of fossil fuels are rapidly declining, electricity consumption in the world, including Latvia and BSR states, increases, resulting in a growing usage of resources required for electricity generation, and although in the world renewable energy resources are becoming increasingly important, however renewable energy cannot completely replace fossil energy resources and by far the world's electricity production are generally based on fossil fuels - coal, peat, natural gas and oil and author believes that this is a huge problem on which are paying too little attention in a long-term.

The aim of the paper is to explore the tendencies of electricity production and consumption in the BSR countries, as well as to find out what sources of electricity generation are being used in these

${ }^{2}$ Corresponding author - e-mail address: Signe.Allena@gmail.com, phone number: +371 27636645

Signe Allena 


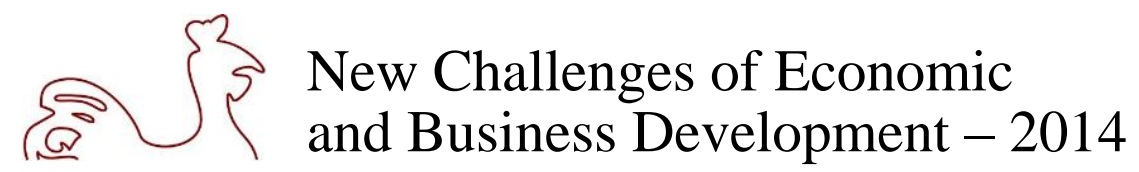

May 8 - 10, 2014, Riga, University of Latvia

countries and how the situation has changed in recent years. To achieve the objective of the study descriptive statistics using data from Statistical office of the European Union - Eurostat and International Energy Agency were used.

In a result of the research, the main tendencies and development of electricity production and consumption and production structure of each BSR country have been identified. It can be concluded that there are significant differences in the BSR countries in those parameters and author offers divide BSR countries into three groups depending on electricity consumption and production per 1000 People - first group with high amount of production and consumption including Finland and Sweden, second group with medium production and consumption including Germany, Estonia, and Denmark and third group of countries with low production and consumption including Poland, Latvia and Lithuania. Also analysing the types of electricity production, it can be seen that in 2013 combustible renewables and waste most are used in Denmark with the share of $17 \%$ and in Finland with the share of $16 \%$, the total leader of wind power usage is Denmark where power of wind reached $36 \%$ in total electricity generation and the biggest shares of fossil fuels used for electricity production are in Estonia where the share was $86 \%$ and Poland where the share was $88 \%$ (International Energy Agency). It is also likely to conclude that provision on electricity in certain countries depends crucially on the situation in other BSR countries as evidenced by Ignalina Power plant disclosure in 2010 in Lithuania which turned Lithuania from electricity exporter country to importer resulting in energy security decrease throughout the BSR.

As concluded in study the largest share of electricity generation in each BSR country constitutes a national resource with its natural advantage - such as wind in Denmark or hydro in Sweden and Latvia, or in less better case it is fossil resource like oil shale in Estonia but in the worst cases countries are unable to secure even half of the electricity demand with own resources so they are dependent on other countries. Nowadays a large incident in a power supply are rare but author believes that it is necessary to increase electricity production and investments in new, green electricity generation forms or investments to expanding existing ones should be done in order to reduce dependence on energy import and therefore additional studies to assess the best solutions for investment in each of BSR countries have to be done.

\section{Bibliography}

European Union EUSBSR EU Strategy for the Baltic Sea Region What is the EUSBSR, 2009. [Online] Available at: http://www.balticsea-region-strategy.eu/pages/what-is-the-eusbsr [Accessed 10 February 2014].

Hindsberger, M., Neybroe, M.H., Ravn H.F., Schmidt, R., 2003. Co-existence of Electricity, TEP, and TGC Markets in the Baltic Sea Region, Energy Policy, 31, pp. 85-96.

International Energy Agency (IEA) Key World Energy Statistics 2013. [Online] Available at: http://www.iea.org/publications/freepublications/publication/KeyWorld2013.pdf [Accessed 23 February 2014].

Katinas V., Marciukaitis, M., Markevicius, A., 2009. Current Situation of the Wind Energy Use and Investigation of Wind Resources in the Costal Region of the Baltic Sea in Lithuania, Renewable \& Sustainable Energy Reviews, 13, pp. 2001-2007.

Ministry of Economics, 2014. Electricity of Latvia, Riga: Ministry of Economics of the Republic of Latvia.

Raadal, H.L., Dotzauer, E., Hanssen, O.J., Kildal, H.P., 2012. The Interaction between Electricity Disclosure and Tradable Green Certificates, Energy Policy, 42, pp. 419-428.

Streimikiene, D., 2007. Monitoring of Energy Supply Sustainability in the Baltic Sea Region, Energy Policy, 35, pp. 1658-1674.

Würzburg, K., Labandeira, X., Linares, P., 2013. Renewable Generation and Electricity Prices: Taking Stock and New Evidence for Germany and Austria, Energy Economics, 40, pp. 159-171. 


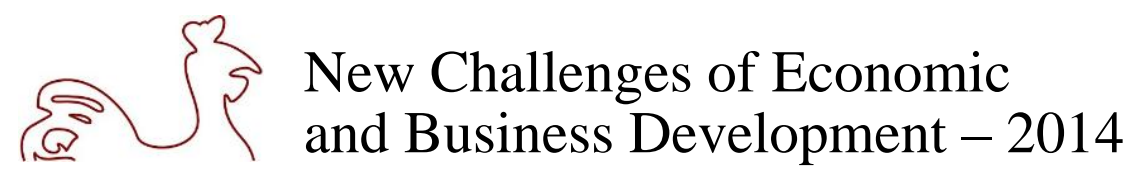

May 8 - 10, 2014, Riga, University of Latvia

\title{
YOUTH UNEMPLOYMENT PROBLEMS IN EUROPEAN UNION AND LATVIA
}

\author{
Daira Barānova, University of Latvia, Latvia ${ }^{3}$
}

Key words: unemployment, youth unemployment, employment

JEL codes: J21, J64, E064

\section{Extended abstract}

The purpose of this paper is to investigate youth unemployment indicators as well as policy tools to reduce youth unemployment rate, compare situation in Latvia and the European Union (EU), and to provide conclusions. The integration of young people into the labour market is an important objective and it is a key policy issue of the European Employment Strategy and in particular in the context of the Youth Guarantee, politically agreed by the European Council on 28 February 2013. However, there are large country differences among the EU member states in the labour market situation for youth and thus policy responses must be tailored to each country's circumstances.

\section{Introduction}

Youth unemployment rate is higher than overall unemployment rate in both in the EU average and in Latvia. If we did not develop policy tools, young people could not integrate the labour market. A question that arises is whether the youth unemployment rate reflects the economic situation or peculiar negative movement among young people. The next question is what is the best labour market policy tools suiting individual. Particular attention should be addressed on so-called NEET group (NEET - not in employment, education or training).

The research aim is analyse youth unemployment in Latvia and the EU and policy to reduce unemployment. Tasks of the research are find out main youth unemployment trends, analyse the reasons of youth unemployment in Latvia and new policy tools in the EU and Latvia.

\section{Methods and results}

Analysis of youth unemployment is based on the International Labour Organization definition of employment and unemployment of youth. Research period of statistical indicators which have been used in the paper is from 2008 till now. In order to achieve the research aim quantitative methods are used. Analysis has been done on basis of materials from the European Commission, the Ministry of Economics of Latvia, the Central Statistical Bureau of Latvia, the Eurostat and the State Employment Agency of Latvia.

Table 1 show that youth unemployment rate in Latvia was lower than the EU average rate in 2008, but from 2009 till 2013 exceed the EU average level. Analysing reasons for high rate in Latvia and EU, part of them could be explained by economic crisis with some gap resulting from GDP changes and part - resulting from other factors, such as, luck of skills, luck of vacancies, luck of experience, luck of motivation etc.

The euro area overall unemployment rate was $12.0 \%$ in December 2013 and EU-28 was 10.7\% in December 2013 (Eurostat, 2014). Youth unemployment rates are generally much higher than unemployment

${ }^{3}$ Corresponding author - e-mail address: daira.baranova@lu.lv, phone number: +371 6703476

Daira Barānova 


\section{$\left\{\begin{array}{l}3 \\ 5\end{array}\right.$ New Challenges of Economic and Business Development - 2014}

May 8 - 10, 2014, Riga, University of Latvia

rates for all ages. The main reason for the general worse labour market performance with respect to adults is related to the lower level of human capital and productivity, and preferences of employers.

Table 1

Youth Unemployment (15 - 24 age group) rate in Latvia and the EU in 2008 - 2013, in per cent

\begin{tabular}{|l|c|c|c|c|c|c|}
\hline & $\mathbf{2 0 0 8}$ & $\mathbf{2 0 0 9}$ & $\mathbf{2 0 1 0}$ & $\mathbf{2 0 1 1}$ & $\mathbf{2 0 1 2}^{2}$ & 2013* \\
\hline Latvia & 13 & 34 & 35 & 31 & 28 & 25 \\
\hline EU-27 & 16 & 20 & 21 & 21 & 21 & 23 \\
\hline
\end{tabular}

* EU-December, 2013, Latvia - $3^{\text {rd }}$ quarter of 2013

Source: Eurostat

The European Commission considers that setting up the Youth Guarantee schemes is a forward looking and fundamental structural reform in the mid-term and long term. The Youth Guarantee aims to ensure that all young people aged 15-24 not in employment, education or training (so-called NEETs) receive a good-quality offer of employment, continued education, an apprenticeship or traineeship within a period of four months of becoming unemployed or leaving formal education (European Commission, 2014). The Youth Guarantee schemes that have addressing acute levels of youth unemployment and inactivity and offering young people better prospects in life: represents a new approach to policy design and implementation. (ICF GHK, European Commission, 2013).

The implementation of Youth Guarantee in Latvia includes necessity to improve access to information and services, building-up partnerships, outreach strategies, anticipation of future skills and labour market needs, individual action planning, developing second-chance opportunities, developing guidance on entrepreneurship and self-employment, supporting mobility, and investing in monitoring and evaluation. In particular to the young people who are NEETs, it is necessary returning them back to the education system, as well as increase attractiveness and quality of vocational education.

\section{Conclusions}

1. High rate of youth unemployment rate could be explained by economic crisis with some gap resulting from GDP changes and partly - resulting from other factors, such as, luck of skills, luck of vacancies, luck of experience, luck of motivation etc.

2. The Youth Guarantee is important policy tool to reduce youth unemployment. However, thus policy responses must be tailored to each country's circumstances.

3. Latvia should pay more attention to the youth who are neither studying nor working, aimed at returning young people back to education system, as well as increase attractiveness and quality of vocational education.

\section{Bibliography}

Eurostat, 2014. Newsrelease. Euroindicators, 17/2014 - 31 January 2014. [Online] Available at: http://epp.eurostat.eceuropa.eu/statistics_expanded/index.plp.Unemployment statistics [Accessed 25 January 2014].

European Commission, 2013. Proposal for an amendment to the Commission Proposal COM (2011) 607 final/2Regulation of the European Parliament And of the Council on the European Social Fund and replacing Council regulation (EC) No1081/2006, 12.3.2013 COM (2013) 145 final, 6 p.

ICF GHK, European Commission, 2013.Bacground paper for the event, Thematic Event 'Practical support for the design and implementation of Youth Guarantee Schemes', La Hulpe, 17-18 October 2013, [Online] Available at: http://ec.europa.eu/social/main.jsp?langId=en\&catId=1079\&eventsId=931\&furtherEvents=yes [Accessed 10 January 2014].

12

Daira Barānova 


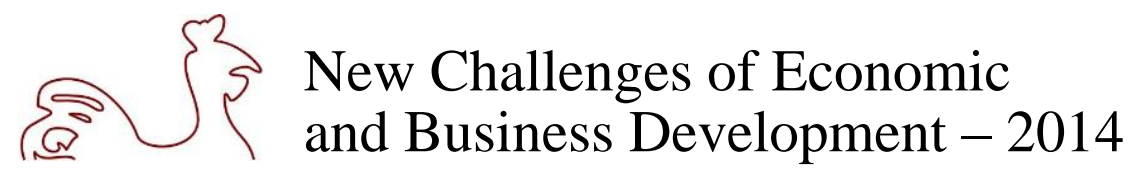

May 8 - 10, 2014, Riga, University of Latvia

\title{
LATVIAN TOURISM BRAND AWARENESS IN GERMAN TOURISM MARKET
}

\author{
Kristīne Bērziṇa, University of Latvia, Latvia ${ }^{4}$; \\ Ilze Medne, University of Latvia, Latvia
}

Key words: tourism, destination, destination marketing, brand awareness

JEL codes: M31, L83

\section{Introduction}

Competition between tourism destinations is no more competition between neighbouring countries as the states compete in scale of whole global world. True globalisation process takes place in tourism industry in even more wider range than in other industries, tourists are choosing their destinations out of hundreds options and are influenced by many factors.

Destination image and identity play a significant role in differentiating between objectively alike alternatives (Baker, Cameron, 2008; Hudson, Ritchie, 2009; Sahbaz, Ciftci, 2011).

Branding provides benefits for both buyers and sellers, hereby for destinations and visitors, by supplying cash flow to destinations and offering safe and enjoyable trips to visitors. Advantages for destination marketing organisations include increased potential to differentiate against places offering similar benefits, increased destination loyalty and increased yield for stakeholders such as local tourism businesses and travel intermediaries. Benefits for the traveller include ease of decision making through reduced search costs, reduced risk, and possibly enhanced brag value (Pike, 2009).

Recent developments in consumer behaviour show the change pattern in information search in tourism industry. Increased significance in tourist decision making process is gained by internet sources - websites, social networks, tourists plan their holidays, make their bookings and service purchases, and share their experiences over the Internet. Tourism enterprises and organisations need to adapt their marketing strategy to the new tendencies. E-marketing instrument incorporation in the common marketing strategy is easier for private tourism companies, but quite often is issue for destination marketing organisations (DMO). Official websites are a vital promotional tool for tourist destinations as they constitute a means of introducing all potential tourists using them to the destination, acting as an information channel on which to base their decisions (Fernández-Cavia, Rovira, Díaz-Luque, Cavaller, 2014). From one point of view Destination Marketing Organisations need to promote the tourism destination as a common area, from other point of view they are promoting different tourism locations and events that are organised by local enterprises.

The aim of the research was to track changes in perception of Latvia as a tourism destination and Latvian tourism brand awareness in the target market of Latvia tourism - Germany, as well as to evaluate the relation between the awareness of brands by German residents grouped by according federal states and Latvian destination official website visits.

\section{Methods and results}

The research involved data of two questionnaires distributed to residents in several German cities and villages in 2011 and other in 2013. During the first survey in 2011 that was conducted in federal states of

\footnotetext{
${ }^{4}$ Corresponding author - e-mail address: kristine.berzina@lu.lv, phone number: +37167034 718
} 


\section{$\left\{\begin{array}{l}3 \\ 5\end{array}\right.$ New Challenges of Economic and Business Development - 2014}

May 8 - 10, 2014, Riga, University of Latvia

Mecklenburg-Vorpommern and Schleswig-Holstein 500 questionnaires have been gathered and evaluated as valid for analysis. The second survey in 2013 was conducted in federal state of Bayern, 300 valid questionnaires have been gathered. Both questionnaires were made to check out the associations in connection with Latvia as tourism destination as well as recognition and associations connected with Latvian tourism brand "Latvia. Best enjoyed slowly" and tourism brand of Riga "Live Riga".

To evaluate the relation between brand awareness of German residents grouped by according federal states and Latvian destination official website visits statistics from destination website was gathered.

Several tools and methods of the SPSS software were used for analysing the data: descriptive statistics, crosstabulation, data correlation.

\section{Conclusion}

Main results and findings are addressed towards Latvian Tourism Development Agency on e-marketing activity efficiency in different states of German tourism market. Detailed results of the survey are in the process of analysis and interpretation that will be included in the conference paper.

\section{Bibliography}

Alptekina G.I., Büyüközkan G., 2011. An integrated case-based reasoning and MCDM system for Web based tourism destination planning, , Expert Systems with Applications, Vol. 38, Issue 3, March, pp. 2125-2132.

Baker M.J., Cameron E., 2008. Critical success factors in destination marketing// Tourism \& Hospitality Research, 8(2), pp. 79-97.

Choia S., Lehtoa X.Y., Morrison A.M., 2007. Destination image representation on the web: Content analysis of Macau travel related websites// Tourism Management 28, pp. 118-129.

Fernández-Cavia J., Rovira C., Díaz-Luque P., Cavaller V., 2014. Web Quality Index (WQI) for official tourist destination websites. Proposal for an assessment system// Tourism Management Perspectives, Vol. 9, January, pp. 5-13.

Hudson S., Ritchie J., 2009. Branding a memorable destination experience: the case of 'Brand Canada'// International Journal of Tourism Research, 11(2), pp. 217-228.

Pike S., 2009. Destination brand positions of a competitive set of near-home destinations// Tourism Management, 30(6), pp. 857-866.

Pike S., Page S.J., 2014. Destination Marketing Organizations and destination marketing: A narrative analysis of the literature, Tourism Management, Vol. 41, April, pp. 202-227.

Sahbaz R.P., Ciftci G., 2011. The effects of brand image on consumers' choice// International Journal of Business and Social Science, 2(20), pp. 227-238. 


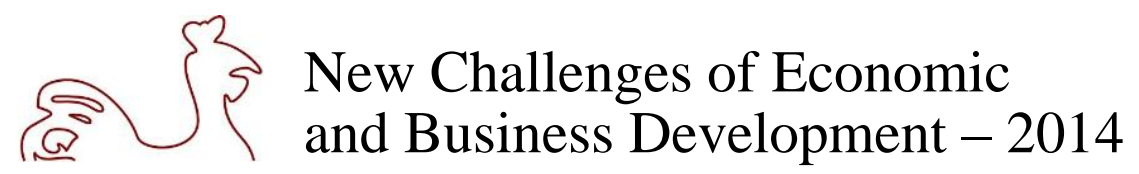

May 8 - 10, 2014, Riga, University of Latvia

\title{
THE INFLUENCE OF MACRO-ENVIRONMENTAL FACTORS TO THE DECISION PROCESS OF SELECTING A COUNTRY FOR EXPANSION STRATEGIES
}

\author{
Helmut Birnleitner, University of Latvia, Latvia/ University \\ of Applied Sciences Kufstein, Austria ${ }^{5}$
}

Key words: Internationalization, Macro-Economic Factors, Decision Process

JEL code: F62

\section{Introduction}

Expansion of companies to conquer and enter new markets or to follow existing customers wherever they expand, became more important over the last decades. Internationalization and globalization are terms which are used commonly in many economic contexts (Adler, N. J., 2008). Industries such as automotive industry, chemical industry, clothing industry, food industry, etc. have their business activities all over the world. Reasons therefore can be to conquer new markets, resources (e.g. raw materials, ...), reducing transports, customers, suppliers, etc. In such processes, companies are forced with many different influence factors. These factors can occur from the company's structure itself (internal factors), these are the so called micro-economic factors (Mussnig, W., 2007) and also the environment of a company plays a very important role by entering new markets, new countries or unknown territories. These factors are defined as the external factors or macro-economic factors (McCarthy, E. J., 1975; Porter, M., 2008). This research project focuses on the macro-level of influence factors and measures the importance of these factors to the decision process of selecting a target country. The targeted country areas in this research project are limited to four major market groups to be tested: Central Europe, Eastern Europe, USA, China.

Companies who have to decide to go abroad are often confronted with many uncertainties from the environmental factors of unknown circumstances. This research project measures the intensity of many different macro-economic factors to the decision process of selecting a country. The aim of this research project is to find out the most important macro-environmental influence factors for the decision process to go abroad. These factors are divided into five groups: Political factors, Economic factors, Society Factors, Technological factors (Pfaff, D., 2004) and Intercultural Dimensions (Hofstede, G., 2001). Each of these groups consists of a number of sub-factors which will be directly measured by a structured questionnaire in combination with a secondary research.

The research question which has to be answered in this project is: "Which macro-economic factors influence the decisions for the country selection of expanding companies?". The results out of this project should clarify the problem of what are the "real" macro-economic factors and hereby should companies help to base their decisions on founded scientific results instead basing the decisions on gut-feelings. Thereby the uncertainties within expansion strategies of companies can be decreased and unusual risks can be reduced. The uniqueness of this research project is, to combine macro-economic factors in terms of their intensity of influencing decisions of companies who intent start a new entity abroad. The literature research showed quite deep analysed macro-economic factors as well as decision processes. But the interlink of these dimensions is only very little analysed or even is missing. This gap should be closed.

${ }^{5}$ Corresponding author - e-mail address: helmut.birnleitner@gmx.at, phone number: +43 6644625893 


\section{$\left\{\begin{array}{l}3 \\ 5\end{array}\right.$ New Challenges of Economic and Business Development - 2014}

May 8 - 10, 2014, Riga, University of Latvia

\section{Methods and results}

To analyse the influence of macro-economic factors to the decision process of selecting target countries combines two different fields of data collection. To gain prefunded data material of macroeconomic factors and testing the correlations to the importance of the selection process of countries, available secondary data will be combined with primary data gained out of structured interviews with experts who have experience with expansion strategies.

The secondary data evaluation has already been done and showed big differences between the targeted country areas in terms of macro-economic factors. These results will be additionally combined with primary data research. If all the data are available, those will be brought together and correlations are going to be tested by factor analysis. The questionnaire also consists of one additional component for each macro-economic factor - the importance of each factor to the decision process for expansion strategies. This is essential because there could be factors which result for a country is very low (bad), but it is not important at all for expanding companies. If this is the case, such factors could be excluded as an influencing factor for expansion strategies.

\section{Conclusions}

The main findings in this stage of the research project are, that many companies who are going abroad and have to select a country are driven by different influence factors. Due to the fact, that this is normally not a daily business, companies are confronted with many uncertainties and gut-feeling decisions. To analyse the macro-economic influence factors and gathering data to get out the importance of specific factors to the country selection process for expansion strategies, it can gain big advantages for companies and can reduce uncertainties and the number of gut-feeling decisions and reducing risks when the real drivers of influence are well known and are more foreseeable.

From the theoretical point of view this research project should reduce a gap of research results in the field of "importance of macro-economic factors to expansion strategies". This in a whole should make such ventures more secure and stable and should increase the possibility of long-term success.

\section{Bibliography}

Adler, N. J., 2008. International Dimensions of Organizational Behavior; $5^{\text {th }}$ Edition; Mason: Thomson Higher Education, 5 p.

Hofstede, G., 2001. Culture's Consequences: Comparing Values, Behaviours, Institutions And Organizations Across Nations; $2^{\text {nd }}$ Edition; Thousand Oaks CA: Sage Publications, 29 p.

McCarthy, E. J., 1975. Basic Marketing; $5^{\text {th }}$ Edition; Homewood/III.

Mussnig, W., 2007. Strategien Entwickeln und Umsetzen; $1^{\text {st }}$ Edition; Wien: Linde Verlag. Pfaff, D., 2004. Praxishandbuch Marketing; $1^{\text {st }}$ Edition; Frankfurt am Main: Campus Verlag GmbH. Porter, M., 2008. On Competition; $11^{\text {th }}$ Edition; Boston: Harvard Business Press. 


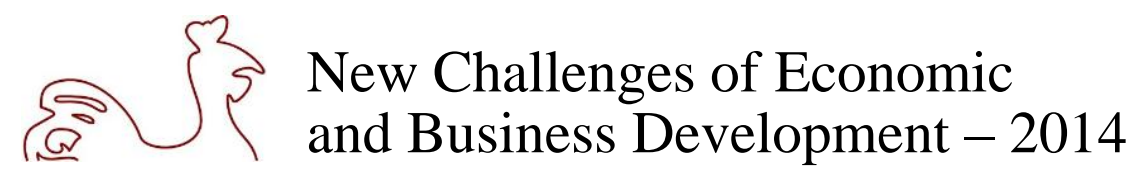

May 8 - 10, 2014, Riga, University of Latvia

\title{
MANAGERIAL HEGEMONY AND SUPERVISORY BOARD ACTIVITY: EVIDENCE FROM POLISH LISTED COMPANIES
}

\author{
Leszek Bohdanowicz, University of Lodz, Poland ${ }^{6}$
}

Key words: corporate governance, ownership structure, boards of directors, two-tier board, Poland

JEL code: G32, G34

\section{Introduction}

Previous studies have emphasized the importance of corporate boards to the creation of company value and the risk linked to shareholder investment, but the present understanding of their role has a lot of gaps. First, most studies have focused on one-tier boards, while little is known about two-tier boards. This especially applies to the efficiency and the activity of supervisory boards. The studies conducted so far have generally found these boards to be passive, but have not explored the underlying causes of this state of affairs. In contrast, the present study is intended to provide in-depth insights and show how often board members meet and how they fulfil their functions. Second, most previous studies have been based on an agency perspective. This study draws on managerial hegemony theory and shows how managerial ownership reduces the role of corporate boards. The purpose of this paper is to investigate how managerial ownership affects supervisory board activity.

\section{Methods and results}

The sample consists of Polish companies listed on the Warsaw Stock Exchange between 2010 and 2012 and involves only non-financial companies, which gives an unbalanced initial panel sample of 207 companies and 463 firm-year observations. The following variables are used for testing the hypothesis: dependent variables (i.e., proxies for supervisory board activity) are supervisory board meeting frequency and number of supervisory board committees; independent variable (i.e., a proxy for managerial hegemony) is managerial ownership; control variables are gender diversity of the supervisory board, supervisory board size, management board size, firm size (i.e., the natural logarithm of total assets), debt ratio, and firm performance (i.e., return on assets). Since data span three years, they are analysed using panel data analysis (a fixed-effects model).

Table 1 illustrates the results of panel data estimation for the sample. The results reveal that the interaction between managerial ownership and supervisory board meeting frequency is negative and significant $(\beta=-3.2767, \mathrm{p}<0.1)$ and the relationship between managerial ownership and the number of supervisory board committees is also negative and significant $(\beta=-0.5977, \mathrm{p}<0.01)$. These findings support the hypothesis that managerial ownership diminishes supervisory board activity. Moreover, they support managerial hegemony theory and the conclusions formulated by Mace (1971). The results are also consistent with Vafeas's findings (1992).

\footnotetext{
${ }^{6}$ Corresponding author - e-mail address: lbohdan@ uni.lodz.pl, phone number: +48 426355059
} 


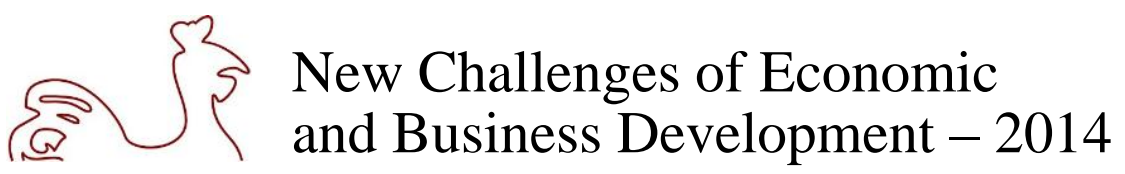

May 8 - 10, 2014, Riga, University of Latvia

Table 1

Panel data estimation

\begin{tabular}{|l|c|c|}
\hline \multirow{2}{*}{$\begin{array}{c}\text { Independent and control } \\
\text { variables }\end{array}$} & $\begin{array}{c}\text { Supervisory board } \\
\text { meeting frequency }\end{array}$ & $\begin{array}{c}\text { Number of supervisory } \\
\text { board committees }\end{array}$ \\
\cline { 2 - 3 } & $-3.2767 \dagger$ & $-0.5977 * *$ \\
$(1.9479)$ & $(0.2435)$ \\
\hline Managerial ownership & - & 0.0056 \\
& & $(0.00801)$ \\
\hline Meeting frequency & 0.3516 & - \\
\hline Number of supervisory & $(0.5095)$ & $0.1303 * * *$ \\
board committees & 0.1209 & $(0.0387)$ \\
\hline Supervisory board size & $(0.3146)$ & 0.0307 \\
& -0.2388 & $(0.0295)$ \\
\hline Management board size & $(0.2343)$ & 0.2523 \\
& 0.9494 & $(0.2117)$ \\
\hline Gender diversity & $(1.6867)$ & -0.2197 \\
& -2.0368 & $(0.1585)$ \\
\hline Firm performance (ROA) & $(1.2578)$ & $-0.3411^{*}$ \\
& 0.0381 & $(0.1811)$ \\
\hline Debt ratio & $(1.4503)$ & 0.0030 \\
& $-1.6378^{* *}$ & $(0.1000)$ \\
\hline Firm size & $(0.7883)$ & 0.0491 \\
& $38.5523 * *$ & $(1.9221)$ \\
\hline Constant & $(15.0779)$ & $0.9319 * * *$ \\
\hline Adjusted R-squared & $0.7075^{* * *}$ & \\
\hline
\end{tabular}

Note: $\uparrow p<0.1 ; * p<0.05 ; * * p<0.01 ; * * *<<0.001$. Standard error is given in brackets.

Source: author's calculations based on data extracted from annual reports.

\section{Conclusions}

This study investigates how managerial ownership influences the activity of supervisory boards in Polish listed companies and they also demonstrate that owner-managers can reduce supervisory board activity in listed companies. This study may be used as a starting point for a discussion on institutional changes in the Polish two-tier and other countries board models with implications for the public authorities that are currently carrying out corporate governance reforms. First, one should consider the introduction of an optional board model (a choice between one-tier and two-tier board models). Second, it would be advisable to impose similar liability on inside and outside directors. Both of these options could increase the activity of corporate boards.

\section{Bibliography}

Kiel, G. \& Nicholson, G. 2003. Board Composition and Corporate Performance: How the Australian Experience Informs Contrasting Theories of Corporate Governance. Corporate Governance: An International Review, 11 (3), pp. 189-205.

Mace, M.L. 1971. Directors: Myth and Reality. Boston: Harvard Business School Press.

Vafeas, N. 1999. Board meeting frequency and firm performance. Journal of Financial Economics, 53, pp. 113-142. 


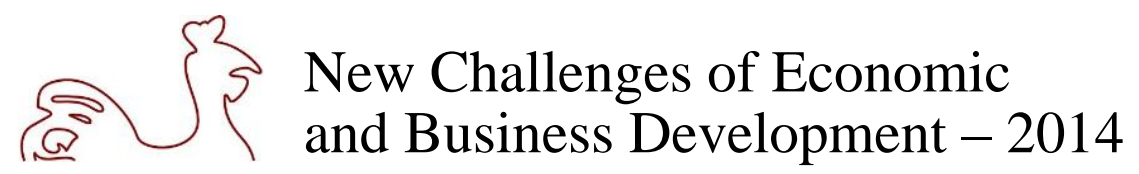

May 8 - 10, 2014, Riga, University of Latvia

\title{
COMPARATIVE ANALYSIS OF INNOVATION PROCESS APPROACHES
}

\author{
Līga Brasliṇa, University of Latvia, Latvia ${ }^{7}$; \\ Kaspars Vīksne, University of Latvia, Latvia; \\ Anda Batraga, University of Latvia, Latvia
}

Key words: innovation sources, marketing, innovation value chain

JEL code: M31

\section{Extended abstract}

\begin{abstract}
Innovation has become one of economic growth engines, where highly important role is played by science and well educated human resources. Innovation in previous economic periods represented economic development background, now days it has become one of the main factors of economic growth. The most recent works of scientists introduces the term ,innovative economy”, thus representing the most developed countries of the world, the current development phase. Despite innovations high importance for economic growth, high attention to innovations impacting macro environments factors, less investigated are innovation value chain issues in microenvironments. Logistic chains and systems development has helped companies to reduce their expenses rapidly. Innovation systems, components and influencing factors has been researched and analysed to conclude that innovation consists of innovation sources, idea processing and concept advancement. Despite popularity of theme, majority of companies the most used innovation sources are brainstorm and intuition as only source of information for innovation idea identification. Scientific literature approach to innovation sources is reserved, leaving a lot of obscure components to hands of "creative marketing". Authors of Paper analyses sources of innovation within innovation development value chain. The main objectives of Paper are to provide a theoretical overview of recently used innovation value chain process, propose improved innovation process scheme and determinate and classify innovation ideas identification sources. The methodology employed in the work is relational content analysis, logical analyses and synthesis of related literature, comparison and generalization, deduction and conceptualization, empirical research.
\end{abstract}

\section{Introduction}

Paper aim is to identify innovation development process, and provide improved model for it, and more deeply analyse and classify innovation development process' first stage - potential innovation idea identification sources of information. Paper tasks: 1) Clarify content of innovation term, 2) Investigate different approaches of innovation process and provide improved innovation process model, 3) Identify and classify innovation idea identification sources of information. Paper Research Object - innovation idea identification. Paper Research Subject - innovation process and innovation idea identity information sources.

\section{Methods and results}

Methods. 1) Monological documentation analysis that provides detailed study of research object. It is based on comprehensive review of existing scientific literature; 2) Grouping method - development

\footnotetext{
${ }^{7}$ Corresponding author - e-mail address: liga.braslina2@inobox.lv
} 


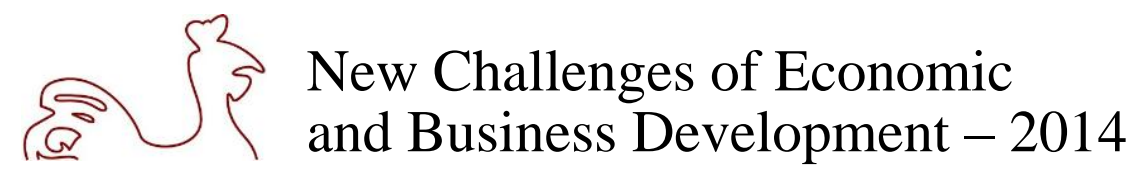

May 8 - 10, 2014, Riga, University of Latvia

process of homogeneous groups that is based on splitting statistical set into several groups according to common characteristics; 3) Graphical analysis method. Recognizes existence of coherence among objects and characteristics of these coherences that allows constructing graphics; 4) Content analysis - systematic evaluation, grouping and interpretation of sources of information form and content.

Novelty of Paper. Different innovation development processes with various approaches are provided. By taking into account conclusions provided by theoretical sources, and authors' practical and academic experience, the improved innovation process model is provided. Summarized and systematized innovation idea identification sources of information that allow companies to systematically create innovation ideas, hugely enlarging field of information sources, avoiding from single-sided brainstorm method appliance.

\section{Conclusions}

There is significant focus in scientific research to innovation influencing factors in macro environments vs. direct influencing activities in micro environment- company which actually develops particular innovation. A lot of various approaches to innovation process are available both in scientific and practical environment. Variations in processes are both - substantial and gradient. Process details are highlighted as extremely important to deliver most valuable innovation process. There is reserved approach from scientist's perspective to very start of innovation process- determination of innovation idea. Concepts and researches of this innovation process part are blurred and uncertain, majority of it deducted to method "brain storm", creativity and abstract ideas generation. Authors of Paper propose new, gradually improved innovation process, based on most approbated Coopers' Stage/ Gate model, enriched with newest discoveries of quality and logistics management and clear and highlighted focus on innovation idea identification through deliberated information sources. Authors of Paper have gathered and systemized information of 13 concrete sources of potential inclusion of innovation idea, based on various scientists' essays about the theme, including the newest approaches both on scientific literature and practical environment.

\section{Bibliography}

Assink, M., 2006. Inhibitors of Disruptive Innovation Capability: A Conceptual Model. European Journal of Innovation Management, Vol. 9, No. 2, Emerald Group Publishing Limited, pp. 215-233.

Baker, M., J., Hart, S., 2008. The Marketing Book 6th edition, Elsevier, Great Britain.

Boudreau K., J., Lakhani K. R., 2013. Using the Crowd as an Innovation Partner, Harvard Business Review. Davila, T., Epstein, M., J., Shelton, R., D., 2013. Making Innovation work., Pearson Education , Inc. FT Press.

Dugan, E., R., Gabriel, K., J., 2013. "Special Forces" Innovation: How DARPA Attacks Problems. Harvard Business Review, October 2013.

Gopalakrishnan, S., Damnpour, F. 2011. A review of innovation Research in economy, sociology and technology management, Omega, The International Journal of Management Science.

Inovacijas un Latvijas tautsaimniecība, LU AA, Riga.

Kotler, P., Keller., K., L., 2006. Marketing Management, 12th edition, Pearson Prentice Hall, New Jersey. Oslo Manual - Guidelines for collecting and interpreting innovation data $3^{\text {rd }}$ edition. OECD, 2005.

Radeka, K., 2013. Mastery of Innovation, A Field Guide to Lean Product Development, CRC Press, Taylor \& Francis Group, New York.

Swaim, R., 2010. The Strategic Drucker, Singapore; Ltd. A Wiley Imprint on behalf of Jossey-Bass.

Trott, P., 2012. Innovation Management and New Product Development, Fifth Edition, FT Prentice Hall, Financial Times, Pearson. 


\title{
New Challenges of Economic
} and Business Development - 2014

May 8 - 10, 2014, Riga, University of Latvia

\section{THE IMPACT OF THE NEW ACCOUNTING DIRECTIVE (2013/34/EU) ON THE NORMATIVE REGULATIONS OF THE REPUBLIC OF LATVIA}

\author{
Inta Brūna, University of Latvia, Latvia ${ }^{8}$; \\ Inta Millere, University of Latvia, Latvia
}

Key words: accounting, financial reporting, legislation, EU directive

JEL codes: M41, M21, K20

\section{Introduction}

On the $26^{\text {th }}$ of June, 2013, the European Parliament (EP) and the European Council (EC) adopted the Directive 2013/34/EU on the annual financial statements, consolidated financial statements and related reports of certain types of undertakings, amending Directive 2006/43/EC of the EP and of the EC and repealing Council Directives 78/660/EEC and 83/349/EEC. The exact effects of any Directive on a particular country will depend upon the laws passed by national legislatures (Nobes Ch., Parker R., 2012). Since in Latvia, in accordance with the criteria, stipulated by the Commission (EC) Regulation No. $800 / 2008,99.5 \%$ of all companies are small and medium-sized enterprises - SMEs (The Ministry of Economics, 2012) and in accordance with the principle "think small first", laid down in the statement, issued by the EC, as well as in accordance with the objective of the strategy "Europe 2020" regarding the reducing of the administrative burden for SMEs (EP and of the EC, 2013), the authors look into the question and research the impact of the application of the requirements of the Directive 2013/34/ES on the SMEs of the Republic of Latvia (RL). Therefore, the authors propose and set forward the objective of the research: to investigate the regulations of the Directive 2013/34/ES of the European Parliament and of the European Council, to compare them with the normative regulations, which are currently in force in the RL, and to make and submit the proposals for the changes in the normative enactments of the accounting regulations of the SMEs in the RL.

\section{Methods and results}

In the research there are applied the methods of general scientific research in economics: of economic analysis and synthesis, logically - constructive, qualitative methods including the methods of the analysis of normative acts. The theoretical and methodological grounds of the paper are the normative acts regulating accounting, works produced as by Latvian so foreign scientists and Internet sources. In accordance with the objective of the work, which has been proposed and set forward, and in accordance with the tasks, foreseen for the achievement of the objective, the authors of the article study the categories of the companies of the RL, and suggest the criteria for the micro-companies, SMEs and large enterprises of the RL. The normative regulations of the RL have been studied, which stipulate the accounting requirements for SMEs, and they have been compared with the new requirements of the Directive 2013/34/ES. During the research, it has been stated that the normative accounting regulations, which are currently in force in the RL, don't comprise all the essential requirements for the accountancy management of SMEs, for the transaction evaluation, for its presenting in the financial accounting reports, as well as it does not include all the explanations of the necessary terms, and it doesn't include the certain requirements for the preparation and drawing-up of the financial statements, etc.

\footnotetext{
${ }^{8}$ Corresponding author - e-mail address: Inta.Bruna@lu.lv, phone number: +371 67034701
} 


\section{$\left\{\begin{array}{l}\left\{\begin{array}{l}\text { New Challenges of Economic } \\ \text { and Business Development }-2014\end{array}\right.\end{array}\right.$}

May 8 - 10, 2014, Riga, University of Latvia

The conclusions, which have been drawn in the result of the carried out analysis, coincide with the opinions and views of the professionals and scientists of other countries (Žarova M., 2013.; Nŏmmiste M., 2012.) regarding the fact that the impact of the new Directive has a varied and diverse nature, not only in relation to the companies coming from the different categories, but also on the entrepreneurial environment in general in the economic systems of different sizes.

\section{Conclusions}

In the results of the research, which has been carried out, the authors have elaborated the classification, recommended for the companies of the RL, grouping the micro-companies, SMEs and large companies according to the following criteria: balance sheet total, net turnover, the average number of employees.

Having carried out the detailed study and research of the requirements of the normative regulations of the RL and having compared them with the relevant provisions and regulations of the Directive, as well as with the opinions and views of the accounting theorists, the conceptual recommendations have been elaborated, which should be taken into account by the legislators of the RL, by amending the regulatory normative accounting laws and enactments.

The study confirms the conclusions, which have been previously drawn in the article „The Comparison of the Accounting Legislation of the RL with the International Requirements Concerning the Components of the Annual Reports Developed by Commercial Companies", published by I.Millere, concerning the fact that the Latvian accountancy corresponds to the accounting traditions of the Continental Europe, and it should be taken into account, when elaborating and adopting the normative accounting regulations of the RL (Millere I., 2013).

The article has its theoretical and practical significance as regards the research of the problematic issues pertaining to the accounting regulations, which shall be observed while preparing and drawing-up the financial statements and reports, but the proposals, in their turn, have their practical application, by making the changes in the normative regulations of the RL.

\section{Bibliography}

European Parliament and of the Council, 2013. Directive 2013/34/EU of the European Parliament and of the Council of 26 June 2013 on the annual financial statements, consolidated financial statements and related reports of certain types of undertakings, amending Directive 2006/43/EC of the European Parliament and of the Council and repealing Council Directives 78/660/EEC and 83/349/EEC, Brussels: European Parliament and of the Council.

Millere, I., 2013. The Comparison of the Accounting Legislation of the Republic of Latvia with the International Requirements Concerning the Components of the Annual Reports Developed by Commercial Companies. Riga: International Scientific Conference "New Challenges of Economic and Business Development - 2013" proceedings, pp. 443-444.

Ministry of Economics, 2012. Entrepreneurship, Riga: Ministry of Economics of the Republic of Latvia. [Online] Available at: http://www.em.gov.lv/em/2nd/?lng=lv\&cat=23394 [Accessed 7 January 2014].

Nobes, Ch., Parker, R., 2012. Comparative international accounting. 12 edition, Harlow: Pearson.

Nŏmmiste M., 2012. Upcoming changes to accounting and financial reporting in the EU Directives. [Online] Available at: http://www.grantthornton.ee/en/publications/articles/upcoming-cha... [Accessed 9 January 2014].

Žarova M., 2013. Could New Accounting Directive Improve European Financial Reporting? [Online] Available at: http://ideas.repec.org/a/prg/jnlefa/v2013y2013i2id97.html [Accessed 10 January 2014]. 


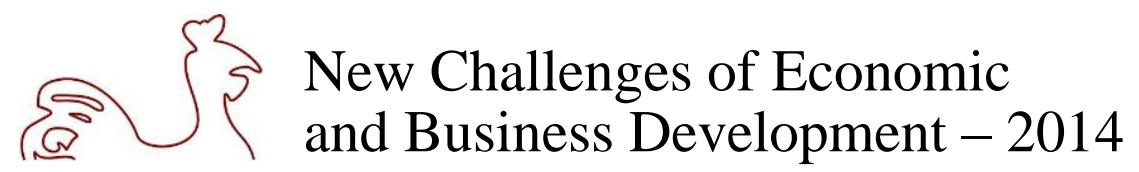

May 8 - 10, 2014, Riga, University of Latvia

\title{
APPROACHES BY PUBLIC ADMINISTRATIONS TO PROMOTE VET INTERNATIONALISATION
}

\author{
Ilze Buligina, University of Latvia'; \\ Biruta Sloka, University of Latvia
}

Key words: public administration, VET, qualifications, internationalisation

JEL codes: J24, J44, M53, I28

\section{Extended abstract}

Innovative approaches in VET strategies and provisions are a high level priority in Europe. This sets new tasks for public administrations in the context of their on-going VET reforms. In Latvia new important initiatives have been started in this regard. In the context of lifelong learning and new economic and employment situation, a focus has been set on more flexible and transparent education and training approaches, also in the context of EU VET priorities.

An increased attention is being to learning outcomes based qualification frameworks for an improved European Qualifications Framework (EQF) implementation (European Parliament, 2008). The European Credit System for Vocational Education and Training (ECVET) has been proposed as an instrument to facilitate the transfer, recognition and accumulation of assessed learning outcomes (LO) (European Parliament, 2009). This approach would enable VET learners to obtain credit based qualifications. This system would also greatly support the internationalisation of VET, similarly to the ECTS approach in higher education. At the same time, on practical level, the public administrations meet barriers in implementing the ECVET system in practice. Not only regarding the legal regulation, but also in relation to the inertia of the VET systems and VET providers to open up for new approaches. Several European countries have different experience of introducing ECVET, this has been discussed also in scientific papers. Different aspects of the realisation of vocational education and training reform has been analysed by researchers from the United Kingdom of Great Britain (McGrath, et al, 2012) where a considerable gap between policy process and educators has been noticed and analysed. Different approaches on the realisation of VET, including competency-based training for the acquisition of professional skills were on research agenda, and conclusions were made that the modular structure has indirect effects on the acquisition of skills through quality teaching and feedback (Boahin, Homnan, 2013). Aspects of team learning in a vocational learning or work setting were investigated by Belgian researchers (Hannes, et al, 2013). A lot of attention has been paid to the effects of collaborative web based VET on learning outcomes (Inayat, et al, 2013), different aspects of more effective texts for VET are on research agenda, as well (Rauchova, Houška, 2013). In 2013 in Latvia a survey and short interviews were carried out among VET providers who have been involved in piloting ECVET based approaches. The results of the survey serve as a basis for the present paper.

The problem of the research is the potential of the ECVET approaches to promote VET internationalisation. The research aim is to evaluate the attitude of VET providers on the usability of the ECVET approach. As a result of the research the conclusion was made that most of the VET providers involved in the implementation of the ECVET approaches in a piloting regime are generally positive toward the ECVET idea, but are more reserved when analysing the process of the practical implementation. With the exception of the VET providers involved in the provision of the regulated

\footnotetext{
${ }^{9}$ Corresponding author - e-mail address: ilze.buligina@ gmail.com, phone number: +371 29478176
} 


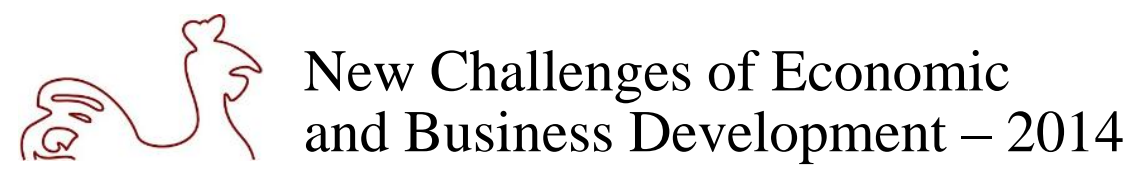

May 8 - 10, 2014, Riga, University of Latvia

professions, e.g. the marine and medical spheres. That leads to the conclusion that in the ECVET piloting process the legal framework and practices in the implementation of the regulated professions could serve as a source for further discussion on making ECVET a reality in European VET systems.

Research methods applied: studies of scientific publications and studies of good praxis other countries. In the empirical study focus group discussions of municipality management, entrepreneurs and educators, as well as a survey was used. The focus of the research has been on the analysis and comparison of the opinions of entrepreneurs regarding the introduction of innovative approaches in VET and municipality readiness to participate in the process. The questionnaire consisted of closed and open questions concerning the introduction of innovative approaches and the potential challenges for such reforms. Most of the questions were stated to evaluate in scale 1 - 10 (where 1 - do not agree; 10 - fully agree) to get the attitude of respondents on the questions. On several questions responses were very different - the views were different and in some cases covered by all scale.

The current research results have indicated that the target groups in question recognised the need for innovative approaches for VET to promote internalisation. In many cases municipality and educators are ready to cooperate locally and internationally in the realisation of VET reform, but this is not always the case with the entrepreneurs. In many cases the employers do not have a reasonable motivation for participation in education process. But on top of this, they need additional motivation for participation in international education processes. Additional studies are needed on the possibilities of ECVET to promote co-operation of stakeholders in the VET reform and provision.

\section{Bibliography}

Boahin, P., Hofman, W.H.A., 2013. Perceived Effects of Competency-Based Training on the Acquisition of Professional Skills. International Journal of Educational Development, In Press, pp. 1-9.

European Parliament \& Council of the European Union, 2009. Recommendation of the European Parliament and the Council of 18 June, 2009 on the Establishment of European Credit System for Vocational Education and Training (ECVET), Official Journal of the European Union, C 155/11, 8.7.2009.

European Parliament \& Council of the European Union, 2008. Recommendation of the European Parliament and the Council of 23 April 2008 on the establishment of the European Qualifications Framework for lifelong learning (2008/C 111/01).

Hannes, K., Raes, E., Vangenechten, K., Heyvaert, M., Dochy, F., 2013. Experiences from Employers with Team Learning in a Vocational Learning or Work Setting: A Systematic Review of Qualitative Evidence. Educational Research Review, 10, pp. 116-132.

Inayat, I., ul Amin, R., Inayat, Z., Salim, S.S., 2013. Effects of Collaborative Web Based Vocational Education and Training (VET) on Learning Outcomes. Computers \& Education, 68, pp. 153-166.

McGrath, S., Lugg, R., 2012. Knowing and Doing Vocational Education and Training Reform: Evidence, Learning and the Policy Process. International Journal of Educational Development, 32, pp. 696-708.

Rauchova, T., Houška, M., 2013. A Calculation Scheme for Measuring the Efficiency of Knowledge Texts for Vocational Education. Procedia Social and Behavorial Sciences, 106, pp. 10-19. 


\title{
$\{3$ New Challenges of Economic and Business Development - 2014
}

May 8 - 10, 2014, Riga, University of Latvia

\section{PURPOSES OF FINANCIAL STATEMENTS AND AUDITING: METHODOLOGICAL PROBLEMS OF CRITERIA DEFINITION AND CLASSIFICATION OF FINANCIAL STATEMENTS DISTORTIONS JUSTIFICATION}

\author{
Svetlana M. Bychkova, Saint Petersburg State Agrarian University, Russian Federation ${ }^{10}$ \\ Elena Y. Itygilova, East Siberian State Technological University, Russian Federation
}

Key words: fairness, trustworthiness, faithful representation, relevance presentation, misstatement of the financial statements, the audit criteria, usefulness, reliability, doctrine of financial statements, normative and descriptive truth

JEL code: M42

\section{Introduction}

The subject of this research is the methodological compliance of financial statements and auditing systems regarding the purposes, namely compliances of preparation and submission of financial statements` criteria to financial statements auditing`criteria. The purposes of preparation and submission of financial statements and the audit of financial statements have to be correctly correlated. It means that criteria of preparation and submission of information in financial statements have to correspond to criteria of verification of audited financial statements. From the methodological point of view this compliance is an important requirement of effective auditing of financial statements.

\section{Methods and results}

To answer that question the following documents were reviewed: conceptual provisions of preparation and the submissions of financial statements accepted by IASB (there are the Framework for the Preparation and Presentation of Financial Statements of 2001 and the Conceptual Framework for financial reporting of 2010), and also the fundamental international standard of audit of ISA 200 "Overall Objectives of the Independent Auditor and the Conduct of an Audit in Accordance with International Standards on Auditing" 2012 and earlier editions.

The analysis of the international standards of financial statements and auditing allowed making the following conclusions:

1. During the period since 2001 and so far were designated, at least, two various methodological situation concerning establishing and correspondence of financial statements preparation and auditing in a concept of development of the usefulness of financial information:

Situation 1. Discrepancy of preparation and submission of financial statements' criteria to the concept of usefulness of financial information and uncertainty of financial statements auditing`criteria.

Situation 2. Discrepancy of preparation and submission of financial statements' criteria to the concept of usefulness and to criteria of audit of financial statements.

\footnotetext{
${ }^{10}$ Corresponding author - e-mail address: smbychkova@mail.ru
} 


\section{$\left\{\begin{array}{l}\left\{\begin{array}{l}\text { New Challenges of Economic } \\ \text { and Business Development }-2014\end{array}\right.\end{array}\right.$}

May 8 - 10, 2014, Riga, University of Latvia

Thus, inconsistency of preparation and submission of financial statements' criteria in the Conceptual Framework and International Accounting Standard 1 "Presentation of Financial Statements" (IAS 1) as result of limited treatment of the concept of "fair representation" does exist. That generates discrepancy of justice criterion on IAS 1 to the criteria of financial statements fair submission in all material aspects on ISA 200.

2. There is an objective requirement to identify the financial statements criteria' assessment as for increasing the degree of information usefulness as for increasing the degree of trust to financial statements from the third parties. To solve those two criteria of financial statements auditing were offered faithful and relevance representation of submission of the financial information, applicable as in a doctrine context of "fair presentation", as in doctrine of "true and fair view".

3. There is a need to solve 3 questions: 1) how to estimate the fulfillment of the established criteria in auditing of financial statements, 2) how to determine the order of their proof, 3) whether these criteria are checkable within applied doctrines of financial statements. The following was offered for reach this purposes:

1) to define criteria of fairness and veracity of financial information.

2) to receive practical justification of audit criteria application within doctrines of financial statements.

3) to prove the necessity of methodological compliance of the usefulness concept, criteria of preparation and submission of financial statements and criteria of audit of financial statements.

\section{Conclusions}

As a result of research the following aims were solved: problems of methodological discrepancy of preparation and submission of financial statements criteria to the concept of financial information usefulness and to doctrines of financial statements and, correspondently, to uncertainty of financial statements auditing criteria. There is presented justification of requirement to definey the criteria of financial statements audit on the basis of the modern concept of usefulness of the financial information determined by the Conceptual Principles of IFRS (2010). It is given in a context of the settled doctrines of accounting. Criteria of justice and reliability of financial information are defined, and also justification of classification of distortions of financial statements on the basis of the established criteria of audit is presented.

\section{Bibliography}

1. ISA 200 "Overall Objectives of the Independent Auditor and the Conduct of an Audit in Accordance with International Standards on Auditing”//Handbook of International Quality Control, Auditing, Review, other Assurance, and Related Services Pronouncements, 2012 Edition, Part I, pp. 72-100.

2. Framework for the Preparation and Presentation of Financial Statements (adopted by the IASB in April 2001).

3. The Conceptual Framework for Financial Reporting (issued by the IASB in September 2010).

4. IASB STAFF PAPER. Meeting Project. Conceptual Framework: Restarting the project. September 2012, IASB. 


\title{
New Challenges of Economic
} and Business Development - 2014

May 8 - 10, 2014, Riga, University of Latvia

\section{INTERNATIONAL JOINT VENTURE PERFORMANCE MEASUREMENT IN CHINA: AN EXPLORATORY STUDY OF SINO-NORDIC JOINT VENTURES}

\author{
Qiling Chen, Shanghai University, People's Republic of China ${ }^{11}$; \\ Xiaosong Zheng, Tallinn University of Technology, Estonia
}

Key words: IJV, performance measurement, dynamic capabilities

JEL code: M16, F44

\section{Extended abstract}

This paper studies the performance measurement of international joint ventures (IJVs) in China. Firstly, relative concepts and theories of performance measurements in IJVs will be shown. Then dynamic capacities theory will be introduced to explain its effects on performance of IJVs. After that, the reason why dynamic capabilities are one of the suitable IJVs' performance measurements will be illustrated. Finally, case study on Nokia through the concept of dynamic capacities will be presented. It is found that apply dynamic capabilities theory as performance measurement is another appropriate method for IJVs in China. Both stability and flexibility do matter for IJVs. Conclusion and suggestions will be made at the end of this paper.

\section{Introduction}

International joint ventures (IJVs) which are widely used in global markets and competition consist of legal organizational firms and their parent companies from different countries (Shenkar and Zeira, 1987). In recent years, with the implementation of reform and opening up policy and China's entry to World Trade Organization, IJVs take the advantages of tax-free policy, resource sharing and low cost of labor in China, which results in dramatically rapid growth of IJV in China since the mid-1980s (e.g., Walsh et al., 1999). According to the data from State Administration for Industry \& Commerce of the People's Republic of China, numbers of projects for contracted foreign direct investment in China adds up to 24925 units in 2012.

Performance measure has been challenges in terms of meeting various needs of stakeholders for years (Globerson, 1985). Since the performance improvement of IJV is a core theme, it is doubtless that the performance measurement has become a centre (Geringerand Hebert, 1991). There are many integrated approaches of performance measurement. The most famous one is the balanced scorecard approach (Kaplan and Norton, 2004). Moreover, other methods obtained reputation including ECOGRAL (Bitton, 1990; Ducq and Valespir, 2005), SMART (Lynch and Cross, 1992) and the Performance Prism (Neely, Adam and Kennerley, 2002).

Dynamic capabilities have been considered as the core of firm strategy, competitive advantage and value creation in recent years (e.g. Teece et al., 1997; Eisenhardt and Martin, 2000; Winter, 2003). Companies need both build stability to create values and to be adaptive to change when circumstances demand (Teece et al., 1997). It is argued that dynamic capabilities affect companies performance through establishing and reorganizing resource positions (Eisenhardt and Martin, 2000), operational routines (Zollo and Winter, 2002), zero-order capabilities (Winter, 2003). There are three sub-dimensions of dynamic capabilities including coordinating activities, learning and strategic competitive response processes (Protogerou et al., 2012). This article will explain how these dimensions and dynamic environments affect the performance of IJVs and then illustrate the validity of dynamic capacities theory as one of the performance measurements for Sino-Nordic joint ventures in China. After that, a specific case study on Nokia using the theory will be given to see its application in the really world, followed by conclusion and suggestions in the last part.

\footnotetext{
${ }^{11}$ Corresponding author - e-mail address: chen_qi_ling@126.com, phone number: +86 136-3642-5507
} 


\section{$2\{3$ New Challenges of Economic and Business Development - 2014}

May 8 - 10, 2014, Riga, University of Latvia

\section{Methods and results}

Case study research method which is a typical approach in social science area will be utilized in this essay. It can be judged by four elements shown in Table 1 that whether case study research method's quality is desirable or not. (Yin, 2003)

Tests for the quality of empirical social research (Yin, 2003)

\begin{tabular}{|l|l|}
\hline \multicolumn{1}{|c|}{ Test } & \multicolumn{1}{c|}{ Purpose } \\
\hline Construct validity & Establishing correct operational measures for the concepts being studied \\
\hline $\begin{array}{l}\text { Internal validity (for explanatory or } \\
\text { casual studies only, not for descriptive } \\
\text { or exploratory studies) }\end{array}$ & $\begin{array}{l}\text { Establishing a casual relationship, whereby certain conditions are shown to lead to } \\
\text { other conditions, as distinguished from spurious relationships }\end{array}$ \\
\hline External validity & Establishing the domain to which a study's findings can be generalized \\
\hline Reliability & Demonstration that the operations of the study can be repeated with the same results \\
\hline
\end{tabular}

\section{Conclusion}

It is found that dynamic capacities have a positive effect on IJVs' performance in high and low levels of environmental transformation, which implies their importance in less dynamic environments. Dynamic environment is a significant role for IJVs' performance. Using dynamic capabilities theory as performance measurement is another appropriate method for IJVs in China.

\section{Bibliography}

Ducq, Y. \& Vallespir, B., 2005. Definition and aggregation of a performance measurement system in three aeronautical workshops using the ECOGRAI method. Production Planning \& Control, 16, pp. 163-177.

Eisenhardt, K. M. \& Martin, J. A., 2000. Dynamic capabilities: what are they?. Strategic management journal, 21(10-11), pp. 1105-1121.

Geringer, J. M. \& Hebert, L., 1991. Measuring performance of international joint ventures. Journal of International Business Studies, 22(2), pp. 249-263.

Globerson, S. 1985. Issues in developing a performance criteria system for an organization. International Journal of Production Research, 23, pp. 639-646.

Kaplan, R. S. \& D. P. Norton. 1992. The Balanced Scorecard: Measures That Drive Performance. Harvard Business Review, 70(1), pp. 71-79.

Lynch, R. L. \& Cross, K. F. 1992. The SMART way to define and sustain success. National Productivity Review, 8, pp. 23-33.

Neely, A. \& Adam, C. \& Kennerley, M. 2002. The Performance Prism: The Score Card for Measuring and Managing Business Success. London: Prentice Hall.

Protogerou, A. \& Caloghirou, Y. \& Lioukas, S. 2012. Dynamic capabilities and their indirect impact on firm performance. Industrial and Corporate Change, 21(3), pp. 615-647.

Shenkar, O. \& Zeira, Y. 1987. Human resources management in international joint ventures: Directions for research. Academy of Management Review, 12, pp. 546-557.

Teece, D. J. \& Pisano, G. \& Shuen, A. 1997. Dynamic capabilities and strategic management. Strategic management journal, 18(7), pp. 509-533.

Walsh, J. P. \& Wang, E., \& Xin, K. R. 1999. Same bed, different dreams: Working relationships in SinoAmerican joint ventures. Journal of World Business, 34(1), pp. 69-93.

Winter, S. G. 2003. Understanding dynamic capabilities. Strategic Management Journal, 24, pp. 991-995.

Zollo, M. \& Winter, S. G. 2002. Deliberate learning and the evolution of dynamic capabilities. Organization Science, 13(3), pp. 339-351. 


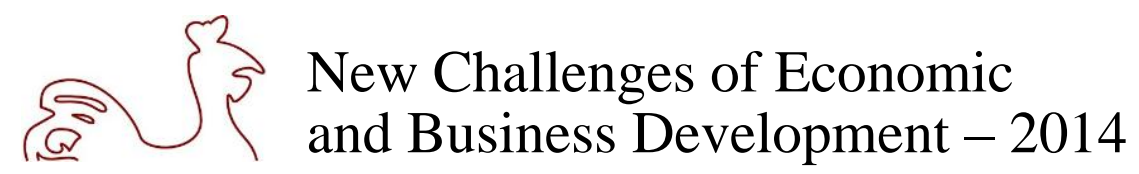

May 8 - 10, 2014, Riga, University of Latvia

\title{
MEASURING THE IMPACT OF SPATIAL FACTORS IN REGIONAL DEMOGRAPHIC DEVELOPMENT OF LATVIA
}

\author{
Aleksandrs Dahs, University of Latvia, Latvia ${ }^{12}$ \\ Key words: spatial econometric analysis, spatial demography, regional convergence and development
}

JEL codes: C21, J11, R23

\section{Extended abstract}

Over the last few decades, one may observe a growing interest in research concerning the spatial aspects of complex socio-economic and demographic processes. It is well known, that on the regional level, Latvia, as well as many other post-Soviet Eastern European countries, face significant challenges of spatial heterogeneity and divergence in terms of both economic and demographic development (SRDA 2012). Econometric analysis of these processes, utilising specialised methods and models, facilitates deeper understanding of the spatial distribution of the indicators under study, and often allows discovering new, previously unseen dimensions of regional development problems.

\section{Introduction}

Most previous sociological and demographic studies concerning Latvia's regional development treat individual geographical units, such as parishes, local municipalities (Novadi), cities or whole statistical regions as independent isolated entities rather than as a system of interconnected geographic units which may and do interact (e.g., through everyday commuting, cross-border family settlement, provision of services etc.). However, in the international scientific literature, and particularly in studies of population dynamics, such spatial effects have long been theorized and applied via several disciplines of social sciences such as geography and regional science, including, but not limited to: spatial diffusion theory, growth pole theory, central place theory and new economic geography theory (Chi G. \& Zhu J., 2008).

With that in mind, this study aims to analyse spatial distribution aspects of several key demographic indicators of Latvia's regions, while attempting to identify the associated socio-economic factors and estimate their impact. By the later comparison of the results of the classical statistical and regression analysis with the results derived from the corresponding spatially adjusted methods, author demonstrated levels of spatial dependency and highlights presence of the inter-regional spill-over effects of demographic indicators among the local municipalities and Republican cities.

Several interim results of this study (e.g. elaborated spatial weight matrixes for Latvian municipalities, distance vectors etc.) may be successfully applied in similar quantitative research in economic and social sciences.

\section{Methods and results}

Within the framework of this study author conducts spatial exploratory analysis of Latvian municipalities and statistical regions data using wide range of research tools, including statistical analysis, cluster analysis and spatial autocorrelation analysis (Voss P. R., et al, 2006). To evaluate the identified spatial patterns and/or anomalies and determine their causality, author applies simple spatially lagged

${ }^{12}$ Corresponding author - e-mail address: Aleksandrs.Dahs@lu.lv, phone number: +371 26488725

Aleksandrs Dahs 


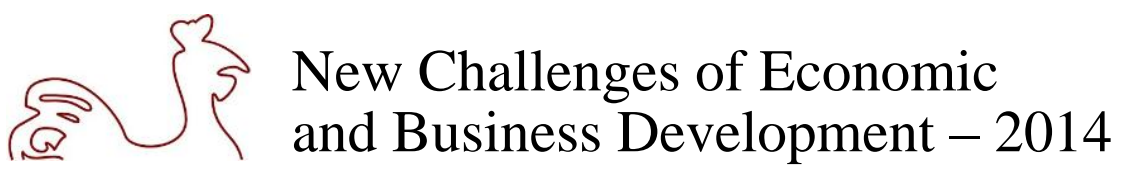

May 8 - 10, 2014, Riga, University of Latvia

regression and mixed-type Durbin models following the principles widely discussed in the literature (Ward M. D. \& Gleditsch K. S., 2008).

Following the initial statistical and exploratory data analysis, in order to capture the general spatial relations of the observed territorial units, a simple square $(n=119)$ spatial weights matrix describing the neighbourhood structure was created, containing the inverse values of geometric distances between the geographical coordinates of the centres of the 119 Latvia's local municipalities and Republican cities. Similar matrices representing other forms of geographical or economic distances (e.g. driving times or flows of trade intensity etc.) may also be created in order to better represent the relations between territorial units under study (Matthews S. A. \& Parker D. M., 2013).

Using the available spatial weights matrix it is possible to perform the series of spatial autocorrelation tests for any of the observed indicators. For the purpose of this study, a Moran's I test is chosen and applied to the key demographic indicators of Latvian municipalities. Test results indicate, that there is a significant spatial autocorrelation among Latvian municipalities in terms of population age structure and economic activity, while such indicators as general fertility rate and registered long-term migration rate present a random spatial distribution throughout the country.

Further, with the purpose of assessing impact of the key socio-economic factors and regional policy instruments on the regional demographic development, author uses simple linear and Spatial Durbin regression models, while choosing a number of social and economic indicators, identified during the previous analysis stages, as the explanatory exogenous variables. From the modelling results one may observe that Spatial Durbin Model has been proven as a feasible and reliable tool for measuring spatial spillovers of the exogenous factors in the basic regional demographic processes in Latvia. In addition, several noticeable empirical conclusions may also be drawn from the modelling results.

\section{Conclusions}

Such analytical approach, combined with the review of existing socio-economic theories and historical information, leads to several conclusions regarding spatial specifics of regional demographic development in Latvia. First, a positive global spatial autocorrelation was found most of the observed demographic indicators of Latvian local municipalities. Second, local spatial autocorrelation analysis, has indicated that for some of the measured indicators spatial autocorrelation pattern is not as strong as expected from the global test results. Finally, presence of the noticeable spatial spill-over effects is identified for several explanatory socio-economic factors, and should be taken into consideration in further modelling and forecasting studies concerning demographic dynamics of Latvian regions.

\section{Bibliography}

Central Statistics Bureau of Latvia [CSB] database. [Online] Available at: http://dati.csb.gov.lv [Accessed 05 November 2013].

Chi G. \& Zhu J., 2008. Spatial Regression Models for Demographic Analysis. Population Research and Policy Review (Part II - Spatial Demography, February 2008), 1(27), pp. 17-42.

Matthews S. A. \& Parker D. M., 2013. Progress in Spatial Demography. Demographic Research, 28(10), pp. 271-312.

State Regional Development Agency [SRDA], 2012. Report 'Development of Regions in Latvia in 2011'. [Online] Available at: http://www.vraa.gov.lv/uploads/Development_of_Regions_in_Latvia_2010_web ENG.pdf [Accessed 25 October 2013].

Voss P. R., White K. J. C. \& Hammer R. B., 2006. Explorations in spatial demography. In Population change and rural society. Netherlands: Springer. pp. 407-429.

Ward M. D. \& Gleditsch K. S., 2008. Spatial Regression Models. Thousand Oaks: Sage Publications. 


\title{
New Challenges of Economic
} and Business Development - 2014

May 8 - 10, 2014, Riga, University of Latvia

\section{CLIENT PERCEIVED PARTICIPATION VALUE: CONJOINT ANALYSIS}

\author{
Milda Damkuvienė, Šiauliai university, Lithuania ${ }^{14}$ \\ Sigitas Balčiūnas, Šiauliai university, Lithuania; \\ Evandželina Petukienè, Šiauliai university, Lithuania
}

Key words: client perceived participation value, client perceived participation benefits and costs, conjoint analysis

JEL code: M31

\section{Introduction}

It is commonly agreed that creating superior value for clients represents the key element in ensuring organization's market success (Zeithaml, 1988; Abu Bakar et al., 2013). Researchers emphasize that the value is always individually perceived and determined by the client (Vargo and Lusch, 2004, 2008). Following S-D logic the client is always a value co-creator. Understanding client perceived participation value is of high importance, as it helps to predict clients' behaviours and intentions toward the organization in future (Arvidsson, 2006; Parasuraman and Grewal, 2000).

Despite the fact that value has become the central concept in scientific research, there are few studies that focus specifically on client perceived participation value. The majority of existing empirical research on customer value has been oriented toward the assessment of how customers perceive value of the service or consumption experiences of goods.

The aim of the article is to reveal the expression of dimensions of the client perceived participation value in services.

The objectives of the article:

1. To assess the relative importance of the dimensions of client perceived participation value

2. To estimate if the relative importance of the dimensions of client perceived participation value differ in different services.

3. To assess client perceived participation benefits and costs in various services.

4. To reveal how the perception of participation benefits and costs varies among the client groups with different socio-demographic features and different experience of using the service.

To achieve the aim of the article the analysis of scientific literature, conjoint analysis were applied.

\section{Methods and results}

Conjoint analysis is used in situations when there is a need to measure the willingness to give-up something for gaining something else, and when the decision maker (client) has to choose between the options with simultaneous variations of two or more attributes and this refers to several attributes (Green et al., 2004).

Upon implementation of the conjoint analysis respondents were asked to assess the hypothetic situations by modelling them as the setup of experienced benefits and costs upon participation.

\footnotetext{
${ }^{13}$ This research was funded by a grant (No. MIP-025/2012) from the Research Council of Lithuania

${ }^{14}$ Corresponding author - e-mail address: milda.d@smf.su.lt, phone number: +370 68619902
} 


\section{$\left\{\begin{array}{l}\left\{\begin{array}{l}\text { New Challenges of Economic } \\ \text { and Business Development }-2014\end{array}\right.\end{array}\right.$}

May 8 - 10, 2014, Riga, University of Latvia

The situations, representing different types (auto repair and cafe/restaurant) services were modelled.

Relevant attributes of participation and their levels were determined according to mostly agreed value dimensions: emotional, social, financial and quality: self-feeling ( 3 levels), doing good to others (2 levels), time (3 levels), price ( 3 levels), and quality (3 levels). Respondents were asked to evaluate and rank the provided participation situations in order of preference: from the most acceptable one (encouraging the participation) to the most unacceptable one. 226 respondents participated in the research

\section{Conclusions}

The research results on client perceived participation value revealed that:

1. Quality is the top ranked dimension of the client perceived participation value. Emotions are the second dimension of the participation value according to the importance. Emotions for the client are more important if compared to the financial or time issues. These factors remain in the third place of the ranking. Social aspects (doing good to other clients) are generally the least important for clients when participating in value creation processes.

2. Client perceived participation value depends upon the type of service. In case of the auto repair service, - quality dimension dominates while in café / restaurant services, emotional and quality components stand together at the same level of importance.

3. It was defined that within the all participation benefits, as well as costs quality and emotions dominate.

4. In the case of café / restaurant services positive emotions and doing good for other clients is more important if compared to the client perceived participation benefits in auto repair services. Quality improvements are more important for clients in auto repair services.

5. Younger clients give higher importance to emotional benefits and costs. Emotional dimension is more important for people who use the service rarely while the dimension of quality - for those who use the service more often (this tendency is observed in the case of the auto repair services).

\section{Bibliography}

Arvidsson, A., 2006. Brands: Meaning and Value in Media Culture. Taylor and Francis: USA.

Abu Bakar, A. R., Al Ruwais, N. M. \& Othman, A. R., 2013. Customer Net Value: a Service Gap Perspective from Saudi Arabia. Global Journal of Business Research, 7(4), pp. 19-33.

Green, P., Krieger, A., \& Wind, J., 2004. Thirty Years of Conjoint Analysis: Reflection and Prospects. In Y. Wind, \& P. Green (Eds.), Marketing Research and Modeling: Progress and Prospects. (117-141). Berlin: Springer Verlag.

Parasuraman, A. \& Grewal, D., 2000. The Impact of Technology on the Quality-Value-Loyalty Chain: a Research Agenda. Journal of the Academy of Marketing Science, 28(1), pp. 168-174.

Vargo, S. L. \& Lusch, R. F., 2004. The Fours Services Marketing Myths: Remnants from a Manufacturing Model. Journal of Service Research, 6(4), pp. 324-335.

Vargo, S. L. \& Lusch, R. F., 2008. From Goods to Service(s): Divergences and Convergences of Logics. Industrial Marketing Management, 37(3), pp. 254-259.

Zeithaml, V., 1988. Consumer Perceptions of Price, Quality and Value: A Means-End Model and Synthesis of Evidence. Journal of Marketing, 52(4), pp. 2-22. 


\title{
$\left\{\begin{array}{l}3 \\ 5\end{array}\right.$ New Challenges of Economic and Business Development - 2014
}

May 8 - 10, 2014, Riga, University of Latvia

\section{SPATIAL ASPECTS OF RETAIL PLANNING IN RIGA}

\author{
Mārtiņš Danusēvičs, University of Latvia, Latvia ${ }^{15}$; \\ Signe Krūmiņa, University of Latvia, Latvia; \\ Džūlija Vozņesenska, University of Latvia, Latvia
}

Key words: retail, spatial planning, site location, store placement

JEL code: L81, M31

\section{Introduction}

Authors research spatial planning of several retail chains in Riga. Chains represent different brands and market segments. Five groceries chains and one drug store chain are analysed. All of these companies are operating nationwide and are subsidiaries of foreign companies. The aim of this research is to analyse the saturation of different districts of a city, to determine possible areas of further expansion, since product placement is an important component of retail marketing activities. The main problem is the difficulty of linking the location of customer residence to the place of them doing shopping. To solve this problem intensity of traffic was used as an instrument to assess the probability of customers from other districts shopping in selected district. The main tasks are identifying indicators available for analysis of city districts, determining the measure of saturation of each district by retail supply. The results of the research can be used by retailers of analysed companies and their competitors to make strategic management on expanding their retail chains in Riga or to analyse other cities using a similar methodology.

The planning of a store portfolio has a direct influence on the success of a retail chain. Unsuccessful locations are a high cost burden for the company and should be avoided (Guy, 1999). That makes an analysis of spatial saturation an important issue for planners. A uniform distribution of retail between centre and suburbs is not to be expected, since there are different attraction forces by districts (Leny, 2007).

\section{Methods and results}

The data set used in this research consists of 143 retail stores operating under five brands and 43 convenience stores. Retail area of each individual store was used as an indicator for the power of the store to service customers. Such an approach has been frequently used in retail market analysis to assess the ability to attract customers without the use of actual turnover, which is often unavailable for analytical analysis. External factors used are the population of every district of the city and availability of public transit and large hubs. The use of population is a classical factor in retail location analysis used extensively (Thrall 2002). The data about districts was obtained from Riga City Council City Development Department. The motivation behind these indicators is to use traffic intensity as an indicator of increasing flow of customers to compensate for districts with low population but high number of customers visiting these districts for employment or as hub between different types of transportation. Such districts would be more preferable for retail stores. City districts were ranked according to the

${ }^{15}$ Corresponding author - e-mail address: martins.danusevics@lu.lv, phone number: +371 67034610 


\section{$2\{3$ New Challenges of Economic and Business Development - 2014}

May 8 - 10, 2014, Riga, University of Latvia

customer saturation by retail area weighted by traffic intensity from other districts. The principle of using a saturation ratio is similar to different saturation indicators used in retail research (Hernandez 2000).

Table 1

\section{District rating based on relative comparison of districts by each criteria and weighted by significance for retail}

\begin{tabular}{|c|c|c|c|c|c|c|}
\hline Criteria & $\begin{array}{l}\text { Centra } \\
\text { district }\end{array}$ & $\begin{array}{l}\text { Kurzemes } \\
\text { district }\end{array}$ & $\begin{array}{c}\text { Latgales } \\
\text { district }\end{array}$ & $\begin{array}{c}\text { Zemgales } \\
\text { district }\end{array}$ & $\begin{array}{c}\text { Ziemeluu } \\
\text { district }\end{array}$ & $\begin{array}{l}\text { Vidzemes } \\
\text { district }\end{array}$ \\
\hline Residents & 0.013 & 0.069 & 0.100 & 0.055 & 0.042 & 0.092 \\
\hline Employment & 0.140 & 0.066 & 0.150 & 0.086 & 0.068 & 0.117 \\
\hline $\begin{array}{l}\text { Population } \\
\text { density per } \mathrm{m}^{2}\end{array}$ & 0.200 & 0.086 & 0.198 & 0.076 & 0.035 & 0.094 \\
\hline $\begin{array}{l}\text { Public transit, } \\
\text { frequency }\end{array}$ & 0.171 & 0.139 & 0.250 & 0.144 & 0.061 & 0.184 \\
\hline $\begin{array}{l}\text { Number of residents } \\
\text { per } \mathrm{m}^{2} \text { of retail area }\end{array}$ & 0.127 & 0.163 & 0.193 & 0.096 & 0.300 & 0.185 \\
\hline Total & 0.650 & 0.523 & 0.891 & 0.457 & 0.506 & 0.672 \\
\hline
\end{tabular}

Source: author's calculations based on own measurements and Riga City Council City Development Department.

To assess the districts from a retail point of view, relative indexes were calculated. The indexes indicated the relative level of population density, level of employment; public transit intensity and residents retail saturation. The relative indexes were weighted using custom weight determined based on authors' opinion. The main findings show districts of city, which are most favourable for further expansion of retail chains. One can argue that the chosen districts have the highest number of resident and transferring customers with the lowest available area of retail stores servicing them.

\section{Conclusions}

The results are a practical help for retailers of different segments in the city of Riga helping them to plan the expansion of chain. A significant expansion potential has been detected for the Latgales district. Additional research should be necessary to assess the possible relation of district retail saturation to performance indicators of individual stores, since the unavailability of financial data hindered such an analysis in current research.

\section{Bibliography}

Guy, C., 1999. Exit Strategies and Sunk Costs: the Implications for Multiple Retailers. International Journal of Retail \& Distribution Management, 27(6), pp. 237-245.

Hernandez, T., \& Bennison, D., 2000. The art and science of retail location decisions. International Journal of Retail \& Distribution Management, 28(8), pp. 357-367.

Leny, Weitz, 2007. Retailing management, The McGraw-Hill Companies Inc., 189 p.

Thrall, G. I., 2002. Business geography and new real estate market analysis. Oxford University Press US., 24 p. 


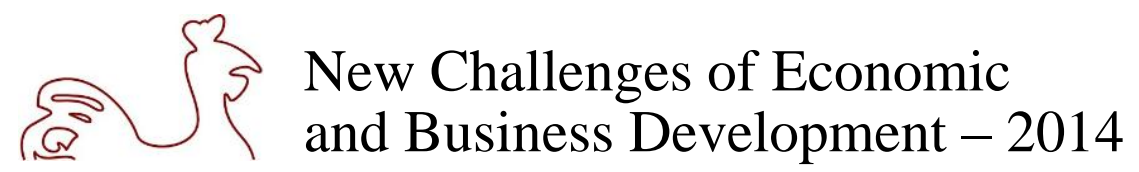

May 8 - 10, 2014, Riga, University of Latvia

\title{
AUDIT FEE SETTING ASSOCIATED RISK FACTORS
}

\author{
Dagnija Daṇēviča, University of Latvia, Latvia; \\ Ieva Aizsila, University of Latvia, Latvia ${ }^{16}$; \\ Roberts Ikaunieks, University of Latvia, Latvia
}

Key words: External audit; Audit fee; Audit quality aspects; Audit market in Latvia

JEL codes: M40, M42, M48

\begin{abstract}
The main purpose of this paper is to analyse and describe the summary of the authors' recent research, which is related to the risks of audit market in Latvia in comparison with the global tendencies. The audit market has been changed since foundation of the Latvian Association of Certified Auditors (LACA) twenty years ago. Presently LACA incorporates 172 practising certified auditors and 154 practicing certified auditor firms. Research shows that despite of the audit fee constraints, auditors are focusing on the high quality audits. The high quality audits are closely related to the interpretation and application of ISAs, auditors' perceptions of the value added auditing as well as robustness of existing audit profession regulators in the respective country.
\end{abstract}

\section{Introduction}

This paper reviews the summary of research that examines the audit fee market in Latvia. The paper is based on the authors' research that has been carried out during the year 2013 and January 2014. The national level analysis of audit fee risk factors has been compared to the risks that are recognized on an international level. The paper defines audit fee as "a fee that an audit client pays an external auditor in exchange for performing an audit". This definition demonstrates that audit fee have an important role in the auditing market in terms of quality and / or quantity.

In order to demonstrate risk factors which are affecting the audit fees and the existing pricing strategies in Latvia, the authors' present their findings which are based on the analysis of expert interviews of year 2013 and 2014 in Latvia and compare their results with worldwide tendencies and situation due to expected reforms in the EU regulations which would enhance audit quality, dynamics and pronouncement of profession.

In this context, the aim of this paper is to define and characterize the main risk factors that exist and which have an influence in the current audit market in Latvia. The main task of this paper is to demonstrate and present the key findings of this study that are related with the audit market in Latvia in order to activate further discussions and analyses based on this research and to have a rise of debates at the conference.

The paper consists of five sections. The first section identifies and describes the various audit fee risk factors that rise from analyses of the professional standards and different academic researches. The second section summarizes the results of the Latvian audit market experts' interviews.

The third section identifies and describes the tendencies of the global audit market as well as the associated risks. In addition, the paper's authors' would like to outline a recent research which was

${ }^{16}$ Corresponding author - e-mail address: aizsila@ hotmail.com, phone number: 37129145484

Dagnija Daṇēviča, Ieva Aizsila, Roberts Ikaunieks 


\section{$\left\{\begin{array}{l}3 \\ 5\end{array}\right.$ New Challenges of Economic and Business Development - 2014}

May 8 - 10, 2014, Riga, University of Latvia

carried out by the International Auditing and Assurance Standards Board - A Framework for Audit Quality, with the aim to improve the audit quality. It describes that audit firms are usually profit making entities and the profitability of an audit firm is usually linked to the relationships between the audit fees charged and costs involved in the gathering of sufficient and appropriate audit evidence. The actual audit fee can be affected by many other factors such as competitive forces, an audit firm's cost base, experience, financial return, provided audit quality management.

The fourth section represents the comparison between the risk factors affecting the audit fees on national and international levels. The last section summarizes the key findings and forms the basis for the future research.

\section{Methods and results}

The research methodology is based on the comparative analysis of the requirements stipulated in documents regulating certified auditor profession in Latvia, the International Standards on Auditing, the International Standard on Quality Control, the national legislation and scientific publications and other bibliographic sources related to the audit fee setting principles. The research introduces literature reviews, exploratory interviews with experts of Latvian audit market, logical analysis and generalization of the audit fee setting principles. The expert interviews provide a clear overview of the current situation in the audit market in Latvia. The paper covers the analysis of authors' conclusions as well as explores and highlights the latest tendencies, recommendations regarding risk factors that affects audit fees.

\section{Conclusions}

The results of the authors' research demonstrate that the risks associated with the audit fee setting are related to a number of different areas. The key areas are related to the auditors' interpretation and application of ISAs according to the circumstances in order to obtain sufficient, appropriate audit evidence, auditors' perceptions of the value added auditing, robustness of existing audit profession regulators in the respective country as well as the right balance between the audit effectiveness and efficiency. These key risk areas must be considered while developing the general audit fee setting principles.

\section{Bibliography}

Dopuch, N. and Simunic, D., 1982. Competition in Auditing: An Assessment. Fourth Symposium on Auditing Research, University of Illinois.

Francis, J. R., 2011. A Framework for understanding and researching audit quality. Auditing: A Journal of Practice \& Theory, Vol. 30, No. 2, pp. 125-152.

The IAASB, A Framework for Audit Quality, 2013. [Online] Available at: http://www.ifac.org/ publications-resources/framework-audit-quality [Accessed 20 December 2013]. 


\title{
$\left\{\begin{array}{l}3 \\ 5\end{array}\right.$ New Challenges of Economic and Business Development - 2014
}

May 8 - 10, 2014, Riga, University of Latvia

\section{L'HYPOTHESE DU MENSONGE MACROECONOMIQUE}

\author{
Mindaugas Dapkus, Université de Vytautas Magnus, Lituanie ${ }^{17}$
}

Mots-clés: macroéconomie, asymétrie informationnelle, identification du mensonge, attentes, Allemagne JEL codes: C12, D82, D84, D22

Problématique de recherche réunie telles questions comme: mentent-ils les acteurs économiques? Peut-on détecter ce mensonge? L'auteur de cette recherche propose et vérifie l'hypothèse de l'existence de la mensongère dans le niveau macro-économique: ici on discute sur possibilité que les firmes industrielles (ou des personnes les représentants) puisse intentionnellement propager l'information faux sur la situation de leur activité et que surtout cette "faux" information puisse être détecté au niveau sectorielle (et même macroéconomique). La recherche de littérature sur la problématique présentée a montré le manque d'investigations de ce type.

Dans cet article le terme «mensonge» est utilisé pour la description du comportement des acteurs économiques qui diffère de ce qu'ils ont exprimé «à la veille» dans les discours publics. Le but de cette recherche est vérifier l'hypothèse qu'on puisse détecter la contradiction systématique entre le «dit» et le «fait», qui est le résultat du certain «instinct de conservation». L'hypothèse repose sur les bases microéconomiques, mais en même temps elle est plus compliquée parce que les acteurs ont les diffèrent motivations pour le mensonge plus on monte de micro vers macro niveau. Les moments de révélation du risque de «mensonge» macroéconomique sont liés aux mouvements cycliques de l'économie: l'auteur de l'article hypothesize que le «mensonge» puisse manifester aux moments de changement de tendance économique (dans les points haut et inferieur de courbe de cycle économique).

Ayant intention de vérifier l'hypothèse de mensonge intentionnel macroéconomique, la méthodologie de l'examen de celle-ci a été proposée. L'idée de cette méthodologie couche sur la nécessité d'évaluer le comportement productif des acteurs économiques dans groups clustérisé de données statistiques, où la clustérisassions est fait à partir de la coïncidence de mouvements des attentes industrielles et ceux de réaction factuelle des nouvelles commandes industrielles (investissements). Autrement dire, nous devons comparer les soit disant "données dures" avec les "données doux". Comme les données «dures», reflétant la réaction réelle, dans cette recherche sont prises les statistiques de l'investissement et de la production industrielle; les données «doux», reflétant les informations «doux» - «dits», sont décrites par les statistiques réunis dans les enquêtes de conjoncture économique (information subjective). L'enquête, comme la méthode de l'acquisition de l'information, ici est traitée comme le «trou» informationnel, à travers duquel les entreprises puisse délivrer information douteux sans aucun risque de la peine morale ou matériel.

La recherche décrit dans ce résumé est menée sur le basis des données mensuelles statistiques d'Allemagne, qui ont été saisonnièrement adaptée. Ici on a distingué quatre groups des données (clusters), énumérées comme: "Optimisme mensongère" (les attentes croix, mais les investissements diminues), "Véritable optimisme" (croissance des attentes et des investissements constaté), "Véritable pessimisme" (négatives attentes en couple avec les négatives investissements) et finalement "Pessimisme mensongère" (attentes négatives exprimées dans le cadre des investissements accrue).

La méthode utilisée - c'est évaluation de la simple régression entre le changement de la production et ce des attentes des entreprises. Ici l'hypothèse à vérifier a été décrite dans le cadre de comportement des firmes dans quatre groupes de données statistiques clustérisés: la relation entre changement de production

${ }^{17}$ Corresponding author - e-mail address: m.dapkus@evf.vdu.lt, phone number: +370 61521158 


\section{$\left\{\begin{array}{l}3 \\ 5\end{array}\right.$ New Challenges of Economic and Business Development - 2014}

May 8 - 10, 2014, Riga, University of Latvia

et des attentes doivent être positives dans les moments de «véritable optimisme et pessimisme» - quand les firmes «ne cache pas» les informations, elles expresses les attentes proportionnelles de leur vision réel de la production d'avenir. Mais, suivant de l'hypothèse, aux moments de l'«optimisme ou pessimisme mensongère» la relation doit se changer: plus les firmes expresses positives attentes, le moins ceci doit manifester dans le niveau de changement productif.

Les résultats de recherche démontre, que l'hypothèse à propos de mensonge intensionnelle macroéconomique est probable. Certain particularités de comportement macroéconomique peut être énumérés: a) relation positive entre le changement des attentes et de production dans les données dites « véritables » est constatée (voir l'index de régression est 0.246 - positive dans «Véritable pessimisme» (1 image); b) négative régression est confirmée dans la groupe de données dites «optimisme mensongère» - quand les firmes prévoit les problèmes dans la production, elles tentes de dissimuler ceci par «propagande» positive ( 1 image - Optimisme mensongère - indice de régression est -0.976 - négative en cas de l'«optimisme mensongère»); c) quand même, la négative relation dans la groupe de données statistiques dites «pessimisme mensongère» n'est pas confirmée; d) la fiabilité des relations détectés est la plus grande dans les données de «véritable pessimisme» et dans le groupe de «optimisme mensongère» (image 1 - indice de détermination dépasse 0.25 ).
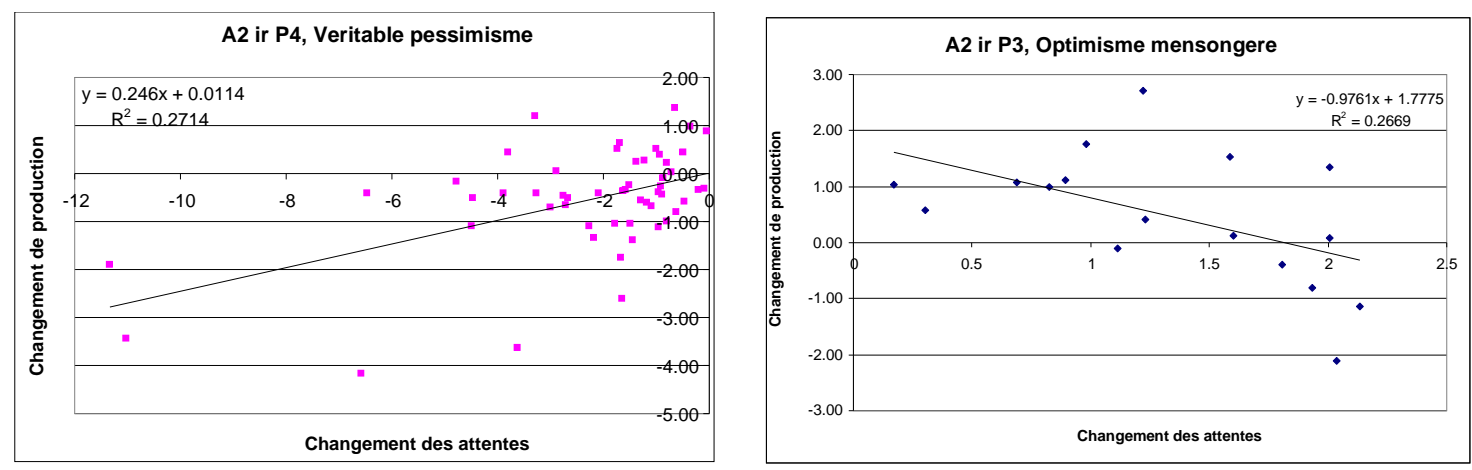

\section{Image 1. Les relations entre les changements de la production et des attentes dans les clusters de données dites d' »Optimisme mensongère » et de « Véritable pessimisme » (calcules faits par l'auteur sur la base des données statistiques d'EUROSTAT)}

En conclusion, les résultats de recherche ont confirmé juste la probabilité de mensonge intensionnelle mais cette recherche doit être approfondie tentant de trouver les autres sources du possible écart entre les données «dures» - objectives et «doux» - subjectives; et ceci peut mener au perfectionnement des méthodes de projection du cyclicité macroéconomique. A l'opinion de l'auteur le «mensonge» est le phénomène globale ce que suggère la possibilité d'appliquer l'idée proposée comme la méthode universelle dans les autres pays. 


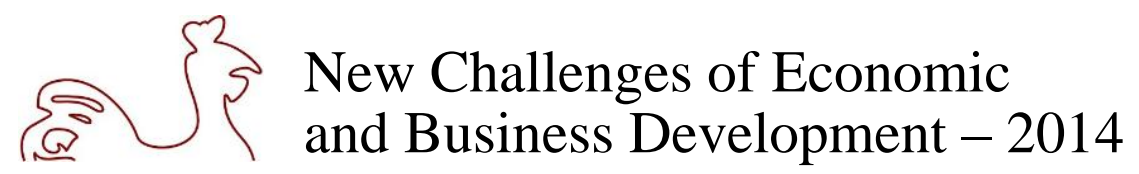

May 8 - 10, 2014, Riga, University of Latvia

\title{
THE NATURE OF TRADE RELATIONS BETWEEN LITHUANIA AND RUSSIA: INVESTIGATION ON APPLICATION OF TRADE BARRIERS IN PERIOD OF 2007 - 2012
}

\author{
Rasa Daugèlienè, Kaunas University of Technology, Lithuania ${ }^{18}$
}

Key words: tariff and non-tariff barriers, export restrictions, international trade, Russia - Lithuania trade relations

JEL codes: F13, F51, O57, P16

\section{Introduction}

International trade is very important activity for such small European Union (EU) country as Lithuania. EU is the biggest trade partner however Russia is the second most important economic partner for Lithuania's producers. It is a key to stress that the specificity of Lithuania's international trade depends on Common trade policy of EU as well as participation in WTO. Despite this fact, international trade relations are based and on bilateral relations. Precisely such are developed between Lithuania and Russia. These trade relations sometimes have very complicated economic - political nature. Despite that, the paper addresses just economic nature of trade relations between Russia and Lithuania. Study is focused on trade barriers (tariff and non-tariff) applied by Russia for the export from Lithuania. The purpose of the paper is to investigate the nature of international trade development between Lithuania and Russia from the standpoint of trade barriers which were applied starting 1998. Theoretical analysis is based on (Anderson, K. and Martin 2012; Anderson, K. and Nelgen 2012; Anderson, K. and Strutt 2012; Anderson 2012; Baldwin 2009; Francois, van Meijl, and van Tongeren 2005; Freeman 2003; Hitiris Th. 1998; Li and Beghin 2012; Molle W. 2006; R.-E. H. and S.-L. A. I. Philippidis G. 2013; S. A. I. Philippidis G. 2007; Tamini L.D., Gervais J.P. 2010; R. Wacziarg 2001; R. and K. H. W. Wacziarg 2008; Winchester N. 2009) scientific works.

\section{Methods and results}

The investigation is based on theoretical analysis of economic theory in order to provide arguments for economic benefit of removing trade barriers as well as to systemize the structure of existing tariff and non-tariff trade barriers. This structure (constructed by author) could be used for further analyses of recognition of trade restrictions application in other countries. The European Commission's TARIC Consultation methodology of application of trade barriers for EU's export to Russia as well as methodology of World Trade Organization for trade profiles (2013) were applied for systemization of different trade restrictions. The empirical findings reflect international trade tendencies between Lithuania and Russia in the period of $2007-2012$.

${ }^{18}$ Corresponding author - e-mail address: rasa.daugeliene@ktu.lt, phone number: +370 37300140

Rasa Daugèlienè 


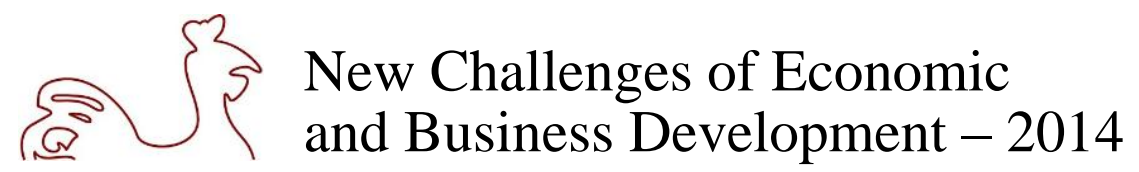

May 8 - 10, 2014, Riga, University of Latvia

\section{Conclusions}

Theoretical analysis showed that there are no doubts that reduction of trade barriers (tariff and nontariff) stimulates the growth of international trade and is beneficial economically. It enhances better information disseminations and technological change between countries. These are the main arguments why international trade restrictions should be controlled in the intergovernmental level.

Theoretically all trade restrictions were divided into to groups: tariff and non-tariff barriers. Respectively import tariffs (customs and import duties); and, quantitative restrictions; import, export licences; fiscal treatment; voluntary export restrictions; specific legal regulations; subsidies.

The analysis of international trade tendencies between Lithuania and Russia in the period of 2007 2012 showed that Russia was second biggest import partner of Lithuania (after the EU) and fourth export partner. Lithuania's balance of trade with Russia was negative because energy related and other raw materials that were necessary for Lithuanian industry and other needs dominated in Russia's import structure.

Statistical analysis allowed to conclude that the main Lithuanian origin goods to Russia (in the period of 2007 - 2012) were: milk and other dairy products; machines and mechanical equipment; live animals (especially pigs); paper and cardboard. The biggest part of Lithuanian import from Russia consisted of energy related and other raw materials. This fact confirms Lithuanians inevitable dependence on Russia's energetic sector (this depicts complicated nature of trade policy).

During the last decade almost a half of all EU member states had trade conflicts or different trade economic sanctions from Russia. Lithuania - with no exceptions. It is a key to stress, that Russia, even being a member of WTO did not refused application of many of trade barriers. Starting the 1998's, the main trade restrictions (tariff and non-tariff) were applied by Russia to Lithuanian export of food products.

\section{Bibliography}

Anderson, K., 2012. Government Trade Restrictions and International Price Volatility. Global Food Security, Vol. 1(2), pp. 157-166.

Anderson, K. and Martin, W., 2012. Export Restrictions and Price Insulation During Commodity Price Booms. American Journal of Agricultural Economics, 94(2), pp. 422-27.

Anderson, K. and Nelgen, S., 2012. Trade Barrier Volatility and Agricultural Price Stabilization. World Development, 40(1), pp. 36-48.

Anderson, K. and Strutt, A., 2012. The Changing Geography of World Trade: Projections to 2030. Journal of Asian Economics, 23(4), pp. 303-323.

Baldwin, R.E., 2009. Trade negotiations within the GATT/WTO framework: A survey of successes and failures. Journal of Policy Modeling, 31(4), pp. 515-525. [Online] Available at: http://linkinghub. elsevier.com/retrieve/pii/S0161893809000398 [Accessed 20 December 2013].

Daugeliene R., 2011. ES ekonomine integracija: priezastys, raida, perspektyvos, KTU: Technologija.

Li, Y. \& Beghin, J.C., 2012. A meta-analysis of estimates of the impact of technical barriers to trade. Journal of Policy Modeling, 34(3), pp. 497-511. [Online] Available at: http://linkinghub.elsevier.com/ retrieve/pii/S0161893811001232 [Accessed 20 December 2013].

Philippidis G., R.-E.H. and S.-L.A.I., 2013. Capturing zero-trade values in gravity equations of trade: an analysis of protectionism in agro-food sectors. Agricultural Economics, 44, pp. 141-159.

Tamini L.D., Gervais J.P., L.B., 2010. Trade liberalization effects on agricutultural goods at different processing stages. European Review of Agricultural Economics, 37(4), pp. 453-477.

Wacziarg, R. and K.H.W., 2008. Trade Liberalization and Growth: New Evidence. World Bank Economic Review, 22(2), pp. 187-231. 


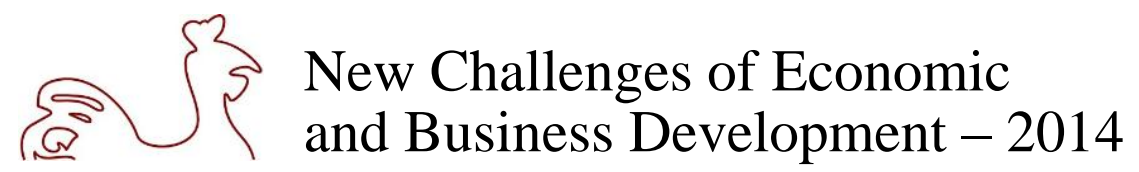

May 8 - 10, 2014, Riga, University of Latvia

\title{
THE ROLE OF INCENTIVES IN ATTRACTING FDI TO THE REGION OF LODZ
}

\author{
Tomasz Dorożyński, University of Lodz, Poland ${ }^{19}$; \\ Janusz Świerkocki, University of Lodz, Poland; \\ Wojciech Urbaniak, University of Lodz, Poland
}

Key words: FDI, Incentives, Lodz Region

JEL codes: F21, R11

\section{Problem statement and research aim}

Incentives for attracting foreign capital in order to modernize production may be used at various levels of government: central, regional or local. Analyses of the role of incentives and their economic rationale have been usually carried out for the first two groups, and most often for the central government, which is the main actor competing for FDI in the global economy.

Yet local authorities, due to their legal and political obligations to their communities, should be very interested in the positive long-term outcomes of FDI entry: new production facilities, more employment opportunities, better paid jobs, increase of production, connection of local suppliers to more advanced enterprises, and additional tax revenues. Their attitudes and professionalism are decisive for economic climate, which is an important factor for foreign entrepreneurs choosing a location for their investments. So two questions could be asked: (1) whether local governments are aware of these opportunities and of the instruments which could help make them happen; and (2) whether foreign investors are sensitive to incentives offered by local authorities in selecting the location for an investment project in a host country.

This paper aims to study the role of the local government (representatives of communes (districts) and counties) in attracting foreign capital to the Province (Voivodeship) of Lodz as of the end of 2011. It is not an economic leader among Polish voivodeships, and in order to stimulate growth of production and employment it undoubtedly needs the assets provided by foreign enterprises: more capital, better technology, superior management skills. Therefore making concrete efforts to attract FDI could be a reasonable policy.

\section{Scope and method of the study}

The assessment of local government units (LGUs) activities with respect to attracting FDI was a part of a broader study on the role played by FDI in the economy of the region. The direct questionnaire-based study was conducted in 2011 and included 275 participants: LGUs and companies with foreign capital (CFCs). Random and quota sampling was applied. Various statistical tools were used for processing the questionnaire data, such as: cross analysis, mean assessment, coefficients of variation, variance analysis, Kolmogorov-Smirnov test and Cronbach's alpha reliability coefficient for the scale. The correlation between FDI location and the incentives used by local government for attracting FDI to the Lodz region was tested and evaluated. In order to verify the correlation hypotheses, the eta coefficient and the regression testing were used.

\footnotetext{
${ }^{19}$ Corresponding author - e-mail address: tdorozynski@ uni.lodz.pl, phone number: +48 504270777
} 


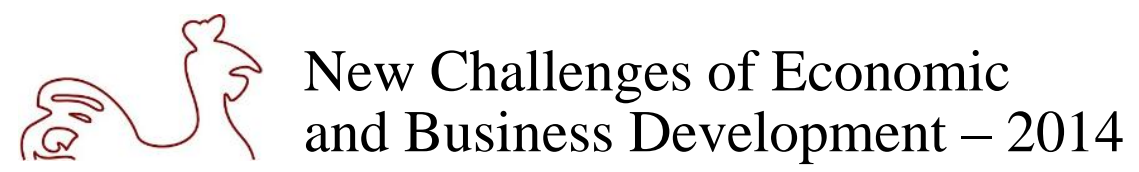

May 8 - 10, 2014, Riga, University of Latvia

\section{Study results}

The majority of LGUs declared, firstly, that they sought investors, and secondly that they did so regardless of whether they were domestic investors or foreign. There were a few activities addressed only to foreign investors. As many as three quarters of communes did not have a ready-made offer of financial support, neither for foreign nor for domestic investors. Tax relief and allowances for property and local charges were the most popular form of financial support granted to investors by all the LGUs.

Potential investors could also receive non-financial support of a promotional nature. Firstly, LGUs were generally ready to provide information on the terms on which one may operate in their respective territory. Secondly, $60 \%$ of the LGUs offered assistance in dealing with various formalities connected with starting a business in a given area (e.g. in acquiring land). Thirdly, most of the LGUs (64\%) could offer developed land ready to start an investment. Such land was of course also available to foreign investors.

According to half of CFCs, the attitude of local authorities (at various levels) was not of great importance when they selected the Province of Lodz. The distribution of opinions and mean answers in this area were very close at the commune, county and province levels. There were also no major differences in the distribution of answers by companies representing various sectors and intensity of export operations.

\section{Conclusions}

The empirical studies conducted in Poland show that investment incentives were of little importance for the inflow of FDI to the country and to its regions. Our study confirms this thesis, but at an even lower level. Representatives of local governments in the Lodz region were aware that competing for foreign investors was necessary to accelerate the development of the local economy, but very few of them engaged in effort to attract foreign capital any more actively than domestic capital.

The financial incentives at their disposal were relatively modest and usually "tailor made", depending on the candidate at hand. Most of the LGUs did not have any specific strategy with respect to, e.g. a preferred type of investment project or making the investment dependent upon the compliance of the proposed project with specified conditions. Incentives were complemented with promotion activities, mostly the provision of information, consultancy and assisting investors in dealing with bureaucratic formalities. Incentives and promotion were not accompanied by any more general reflection on the costbenefit analysis, i.e. of comparing the outcomes of FDI against the costs of attracting it.

Summing up, we can say that relationship analysis, which we conducted has made us dismiss the thesis on positive effect of incentives offered by local government units to attract foreign investors into the region.

\section{Bibliography}

Harding, T., Javorcik B. S., 2011. Roll Out the Red Carpet and They Will Come: Investment Promotion and FDI Inflows, The Economic Journal 121 (December), pp. 1445-1476.

James, S., 2009. Incentives and Investments: Evidence and Policy Implications. ICAS of the World Bank Group.

Moran, T. H., Graham E. M., Blomström M. (eds) 2005. Does Foreign Direct Investment Promote Development?, Washington, DC: Institute for International Economics.

Świerkocki J., 2011, Znaczenie zachęt dla napływu bezpośrednich inwestycji zagranicznych do Polski, Przegląd Organizacji nr 6, pp. 28-32.

Temiz, D., Gökman, A., 2014. FDI Inflow as an International Business Operation by MNCs and Economic Growth: An Empirical Study on Turkey, International Business Review 23 (January), pp. 145-154.

WIR, 2013. Global Value Chains: Investment and Trade for Development. United Nations, New York and Geneva 2013. 


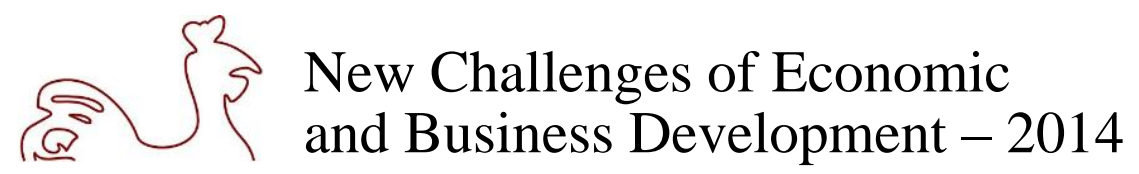

May 8 - 10, 2014, Riga, University of Latvia

\title{
THE IMPACT OF EU POLICY ON SOCIAL DEVELOPMENT OF LATVIA
}

\author{
Elena Dubra, University of Latvia, Latvia ${ }^{20}$ \\ Kristaps Soms, University of Latvia, Latvia
}

Key words: EU strategies, cohesion policy, socio-economic development

JEL codes: E24, F15, F42, I38, O19, O52

\section{Extended abstract}

The purpose of this research is to introduce evaluation of European Cohesion Policy in Latvia, especially on eventual social development in the context of the new strategy "Europe 2020". The strategic goals of EU cohesion policy are discussed as well as the development challenges for improvement of the socio-economic well-being of states and regions in the European Union and also to avoid disparities. The objective of this study is to assess Latvian social level and its development, in order to reach goals of "Europe 2020" strategy. The main emphasis of this research lies in the complex approach to the EU cohesion policy analysis and its implementation in Latvia.

The research methodology is based on the EU cohesion and convergence economic theories analysis and on external and induced variables estimations: situations of the economic and welfare level. This research investigates major variable factors. This research presents information about various different socio-economic indicators and indexes. A major focus in this study is devoted to social cohesion analysis in Latvia. This study contains and discusses changes of key concepts related to the cohesion policy of the European Union and compares objectives and general outlines of the cohesion period 2014-2020 in the framework of Europe as a whole, as well as its impact on Latvian economics and living conditions.

The flagship initiatives of the Europe 2020 strategy, including the Platform against Poverty and Social Exclusion and the Agenda for New Skills and Jobs, support efforts to reach these targets. Through its Social Investment Package, the Commission provides guidance to Member States to modernise their welfare systems towards social investment throughout life. The package complements the Employment Package, which sets out the way forward for a job rich recovery, the White Paper on Pensions, presenting a strategy for adequate, sustainable and safe pensions, the Youth Employment Package, which deals specifically with the situation of young people. As social policies are an integral part of the Europe 2020 Strategy, the Commission also supports EU countries' efforts to address their social challenges through the actions foreseen in the Platform against Poverty and Social Exclusion and Social Investment Package as well as the EU funds, in particular the European Social Fund.

The current socio-economic situation analysis in Latvia and forecast of socio-economic development for the coming 7 years (2014-2020) include the following themes:

- The quality estimations of the socio-economic development in Latvia;

- The main directions for the achievement of the economic situation improvement in Latvia;

- Poverty and income disparity problems solution;

- Labour market and education policy problems and solutions for its alignment;

- Forecasts of socio-economic development and migration process;

- The convergence into EU based on the resources of European Structural Development Funds.

${ }^{20}$ Corresponding author - e-mail address: elena.dubra@lu.lv, phone number: +371 67034762 


\section{$\left\{\begin{array}{l}3 \\ 5\end{array}\right.$ New Challenges of Economic and Business Development - 2014}

May 8 - 10, 2014, Riga, University of Latvia

The macroeconomic and social development scenario in Latvia is based on the assumption that the situation in the Eurozone will continue stabilising and growth in the Eurozone will gradually recover from the 2014.

The main results and conclusions reflect the overall social-economic situation in the EU and Latvia and present current and future European Cohesion policy's impact on social development of Latvia. The discussion consist socio-economic situations analysis in the EU and Latvia, national economy development estimations and trends in the context of the future's strategies of Latvia and "Europe 2020" strategy goals.

\section{Bibliography}

Becker E., von Ehrlich M., Fenge R. 2008. Going NUTS: the effect of EU structural funds on regional performance, CESifo Working Paper, pp. 24-95.

Checherita C., Nickel C., Rother P. 2009. The Role of Fiscal Transfers for Regional Economic Convergence in Europe, ECB Working Paper, pp. 10-29.

Dall'erba S. and Le Gallo J. 2008. Regional convergence and the impact of European structural funds 1989-1999: A Spatial Econometric Analysis, Papers in Regional Science, 87(2), pp. 219-244.

Halmai P.,Vasary V. 2010. Real Convergence in the new Member States of the European Union, The European Journal of Comparative Economics, Vol. 7, No. 1, pp. 229-253.

Marzinotto B. 2012. The Growth Effects of EU Cohesion Policy: A Meta-Analysis, Working Paper 2012/14, Bruegel, pp. 3-5, 11-15.

The Organisation for Economic Co-operation and Development (OECD). How's life? 2013 Measuring wellbeing. [Online] Available at: http://www.oecd.org/statistics/howslife.htm [Accessed 28 December 2013].

European Commission. 2013. Europe 2020 targets. The 5 targets for the EU in 2020. [Online] Available at: http://ec.europa.eu/ europe2020/targets [Accessed 09 December 2013].

European Commission. 2013. Country-specific Recommendations - final version, approved by the Council. [Online] Available at: http://ec.europa.eu/europa2020/europa-2020-in-your-country/latvia/ [Accessed 05 May 2014].

Ministry of Economics of the Republic of Latvia, 2013. Report on Economic Development of Latvia, June, 2013. Riga. [Online] Available at: http://www.em.gov.lv [Accessed 7 January 2014].

Ministry of Economics of the Republic of Latvia. 2010. Economic Development of Latvia "Europe 2020" Strategy. Presentation 7 June 2010. [Online] Available at: http://www.em.gov.lv [Accessed 19 December 2013].

The Cabinet of Ministers of the Republic of Latvia, 2012, National Development Plan of Latvia for 20142020. [Online] Available at: http://www.pkc.gov.lv/NAP2020/20121220 [Accessed 19 December 2013].

Central Statistical Bureau of Latvia, 2012-2013. Statistical Yearbook of Latvia. [Online] Available at: http://www.csb.gov.lv/ [Accessed 5 January 2014].

Eurostat. Income and living conditions database. [Online] Available at: http://epp.eurostat.ec.europa.eu/ portal/page/portal/income_social_inclusion_living_conditions/data/database [Accessed 8 January 2014]. 


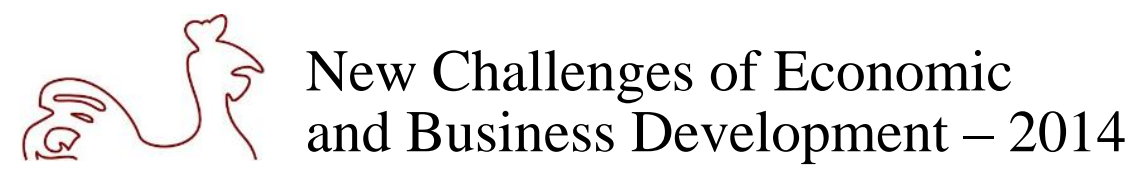

May 8 - 10, 2014, Riga, University of Latvia

\title{
INTERNAL AUDIT SYSTEM CHANGES IN LOCAL GOVERNMENTS OF LATVIA
}

\author{
Ivita Faituša, University of Latvia, Latvia ${ }^{21}$
}

Key words: internal audit, local government, methodology

JEL codes: M42, H790

\section{Introduction}

In Latvia Internal Audit law there is stated that internal audit systems, internal audit organization and conducting internal audits shall be determined by the Authority. To ensure effective performance of the internal audit function local government may enter into cooperative agreement with the relevant ministries of the person into the ministry of internal audit system. The aim of this article is to find out what internal auditing methodology is used by internal auditors in local governments of Latvia. The tasks of this research are: to make survey of Latvia local governments, to make data collection and analysis. In Latvia is still not in place an internal audit system in local government's level and because of that this research is topical. In Latvia were defended one dissertation about state administration internal audit (Magone I., 2010) and one dissertation about internal audit system in local governments (Sulca R., 2010).

\section{Methods and results}

International Standards for the Professional Practice of Internal Auditing clarify that the chief audit executive must effectively manage the internal audit activity to ensure it adds value to the organization; the chief audit executive must establish risk-based plans to determine the priorities of the internal audit activity, consistent with the organization's goals, the chief audit executive must establish policies and procedures to guide the internal audit activity, the form and content of policies and procedures are dependent upon the size and structure of the internal audit activity and the complexity of its work (IIA., 2012).

The methods of this research are survey method, monograph method, statistical methods.

Author made survey of Latvia local governments, made data collection and data analysis. Data from $30.25 \%$ local governments were collected and analyzed.

Each internal auditor in local governments makes audits by internal audit methodology (46\%), International Standards for the Professional Practice of Internal Auditing (23\%), International Audit Standards (8\%), Latvian legislation and Local government binding rules (85\%). Just one Local Government internal auditor is member of the Institute of Internal auditors, just in 54\% of local governments is approved internal audit methodology

From the results of the research the author has come to the following conclusions that no Internal audit system in Latvia local government level and no common approach in Latvia local governments internal auditing because of Latvian legislation rules. Authors' suggestion - common system for local governments internal auditing is necessary for comparable and transparent information of local government's activities.

${ }^{21}$ Corresponding author - e-mail address: ativi@ inbox.lv, phone number: +371 26141974

Ivita Faituša 


\section{$2\left\{\begin{array}{l}3 \\ 5\end{array}\right.$ New Challenges of Economic and Business Development - 2014}

May 8 - 10, 2014, Riga, University of Latvia

\section{Conclusions}

No Internal audit system in Latvia local government level and no common approach in Latvia local governments internal auditing because of Latvian legislation rules. Each internal auditor makes audits by internal audit methodology (46\%), International Standards for the Professional Practice of Internal Auditing (23\%), International Audit Standards (8\%), Latvian legislation and Local government binding rules (85\%). Just one Local Government internal auditor is member of the Institute of Internal auditors, just in 54\% of local governments is approved internal audit methodology. The common system for local governments internal auditing is necessary for comparable and transparent information of local government's activities.

\section{Bibliography}

International Standards for the Professional Practice of Internal Auditing (Standards) 2012 The Institute of Internal Auditors. [Online] Available at: http://iai.lv/lv/standarti [Accessed 10 January 2014].

Magone I. Valsts iestādes funkciju audita metodologijia un tā veikšanas process Latvijā :promocijas darbs, LU, EVF, 2010. [Online] Available at: https://lira.lanet.lv/F/EEANFFIDUUHXFUTS77RAMCE 84J71A5SJ76857GEG6G3V36U2UH-28715?func=full-set-set\&set number $=007634 \&$ set entry $=000$ 001\&format=999 [ Accessed 11 January 2014].

Šulca R. Latvijas pašvaldību iekšējā audita sistēmas attīstības iespējas :promocijas darba kopsavilkums ekonomikas doktora (Dr. oec.) zinātniskā grāda iegūšanai. 2010 [Online] Available at: https://lira.lanet.lv/F/EEANFFIDUUHXFUTS77RAMCE84J71A5SJ76857GEG6G3V36U2UH-2169 5? func=full-set-set\&set_number=007576\&set_entry=000001\&format=999 [Accessed 11 January 2014]. 


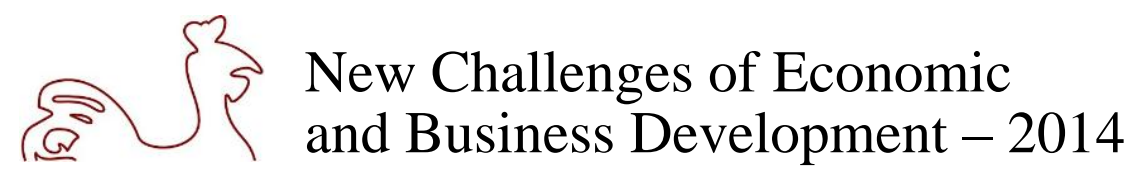

May 8 - 10, 2014, Riga, University of Latvia

INTERNATIONAL FRANCHISE PARTNER SELECTION MODEL

\author{
Christiane Gaul, University of Latvia, Germany ${ }^{22}$
}

Key words: model, franchising, franchisee selection

JEL code: M16

\title{
Extended abstract
}

Cooperations are the base for many business activities ever since. Especially vertically cooperating systems have developed in many commercial sectors at present. One of their advantages is the unification of main distribution channel members under one umbrella. Therefore, they present themselves externally as one unit, although internally, several units work hand in hand. These systems have gained worldwide acceptance. One example of a vertically operating system is franchising. It is embedded in a network of individual trading parties. Franchising is a continuously growing international distribution solution.

After spreading mostly from the United States, also European countries have adopted franchising as a well recognized expansion strategy. Due to its growing success and rapid growth, this business approach has comes into the focus of researchers over the years. Numerous success factors describe franchising. Amongst them is the concept of recruiting suitable partners who fit the systems at the same time, as they fit other parties in the network to build a strong franchisee system.

Selecting adequate partners to expand the systems and to trigger growth, coverage, market share, and popularity has turned out to be a challenge in franchising. Business partnerships need to prosper; otherwise they are not worth the compound effort. Poor screening and poor selection work hinder fruitful alliances and cost money instead of earn money. These challenges have existed for a long time and have not only kept business parties occupied, but also academic researchers. Researchers are united in the thought of selecting qualified franchisees; it is perceived as the franchisor's single most pervasive operating problem (Clarkin and Swavely 2006, p. 134), which prevails for national and international franchising alike.

The goal of this academic contribution is developing a two-step model for successful partner selection in international franchising. The model is based first on cross border literature review elements, and second, paired with expert interviews from German speaking countries to finally determine a questionnaire for franchisors, in order to build the ideal profile of franchise candidates for Germany based franchisors.

In detail, the model consists of attributes found in previous studies to be significantly influencing the ideal franchisee profile. Cross border partner selection adds to the difficulty overall. For this reason, a special feature in this model is the understanding that national franchisee selection may differ from international franchisee selection. Difficulties of international business and also international franchising may arouse in the absence of awareness of certain challenges. These obstacles in the target market include distribution of wealth, egalitarian of society, types of laws, foreign investment procedures, communication styles, human relationship dimensions, freedom of press, political and religious boundaries, gender issues, consumer and commercial spending, and many more topics (Hero 2010, p. 164). Both parties, franchisor and franchisee, have to be aware of prevailing differences and resulting challenges, as it is equally difficult for a franchisor to export a certain system into problematic market, as it is for a franchisee to import a non-fitting system structure into a certain market. In addition,

${ }^{22}$ Corresponding author - e-mail address: c.gaul@andre-media.de, phone number: +49-941-69530-0 


\section{$\left\{\begin{array}{l}\left\{\begin{array}{l}\text { New Challenges of Economic } \\ \text { and Business Development }-2014\end{array}\right.\end{array}\right.$}

May 8 - 10, 2014, Riga, University of Latvia

compatibility of the parties, goodwill, and trust are needed for any relationships, and so they are needed for franchiseships. In a next step, experts shall verify the literature elements and improve a questionnaire, which should be sent to actual franchisors within Germany. To determine the preferred franchisee profile in the future, franchisors will be asked to describe their favourable characteristics when searching for candidates.

Main results are yet to be found after future verification of the two-step model. Final results will help any German franchisor to fine tune its approach of franchisee selection and to professionalize the selection phase in order to chose more profitable candidates. Nevertheless, existing literature gives hints on favourable characteristics found in mostly North American and Australian studies, only one study of the German market was found.

Generally, researchers distinguish between strategies of selection processes and strategies of selection characteristics. Some recruiting steps stick out, due to their importance given by the franchisor. Establishing well-conceptualized processes inside the company before entering the selection procedure on a personal basis is an absolute necessary step to discovering talented individuals. First, decision making involving more department heads is an advantage to increase the quality of the finally selected applicant. This allows covering and screening a wider spectrum of demanded skills. The candidate is assessed more critical and missing qualifications can be addressed and corrected early. Second, the understanding of the difference of country markets, including culture is another relevant focus the headquarter needs to include in its expansion strategy. The research and preparation for these potential knowledge gaps brings a company closer to understanding the individuals interested in a specific franchise market. Then, a franchisee selection process flows empathetically and later misunderstandings are minimized.

The findings of this contribution, which consists of the creation of a two-step model, are first the process of establishing the framework for a valid and tested questionnaire to hand on to German franchisors. Second, within the process of establishing the questionnaire, the feedback from experts is expected mostly in line with the collection of hints from literature. This gives a stable base for further data collection and points the data collector in the right direction to pursue the overall goal of find out about the preferred profile of a candidate for German franchisees within Germany and also abroad.

\section{Bibliography}

Hero, M., 2010. International Franchising: A Practitioners guide, London: Sian O’Neal.

Clarkin, J.E. \& Swavely, S.M., 2006. The Importance of Personal Characteristics in Franchisee Selection. Journal of Retailing and Consumer Services. 


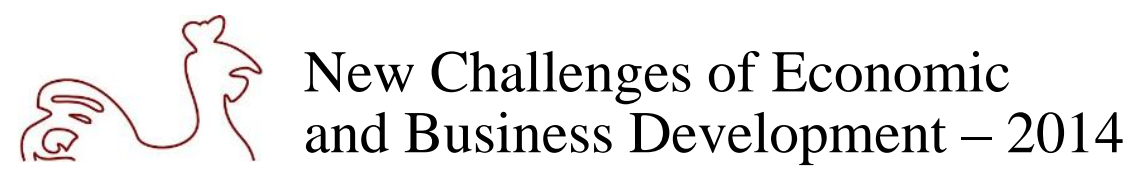

May 8 - 10, 2014, Riga, University of Latvia

\title{
ETHICAL CODES IN LITHUANIAN SMALL AND MEDIUM-SIZED ENTERPRISES: PROBLEMS AND SOLUTIONS
}

\author{
Jolita Greblikaite, Kaunas University of Technology, Lithuania ${ }^{23}$
}

Key words: ethical codes, business ethics, Lithuanian SMEs

JEL code: M140

\section{Introduction}

The scientific problem of this article is how ethical codes might be more effectively implemented in activity of Lithuanian small and medium-sized enterprises (SMEs). The aim of the article is to analyze the importance of ethical codes in enterprises disclosing the results of empirical research made in Lithuanian SMEs. Research object of this article is appliance of ethical code in an enterprise. The tasks of the article are: to ground the importance of ethical codes in enterprise activity; to present situation of ethics' implementation in Lithuania; to reveal the results of empirical research about ethical codes made in Lithuanian SMEs; to evaluate practical situation and propose solutions how more effectively implement ethical codes in Lithuanian SMEs activity. Novelty/ Value of findings. The results of this research are rather new and valuable to SMEs in Lithuania preparing implement ethical codes in their activity as well as results are valuable to further research about implementation of ethical codes situation in Lithuania. Findings are important for politicians and society, supporting ethical values in business environment.

\section{Methods and results}

The arguments for and against ethical codes still exist. Researchers are arguing about effectiveness and necessity of ethical codes in business (Rayborn C. A. and Payne D., 1990; Bass B. M., Steidlmeier P, 1999; Adams J. S. et al., 2001; Wotruba T. R. et al., 2001; Asgary N., Mitschow M. C., 2002; Pater A., van Gils A., 2003; Schwartz M. S., 2005; Garcia-Marza D., 2005; Rodriguez-Dominguez L. et al., 2009; Svennson G. et al., 2010; Forsyth D. R., O’Boyle E. H. Jr., 2011; Williams S., 2011; Sanchez- Garcia I. M. et al., 2013). Based on theoretical assumptions such research methods were selected: scientific literature analysis, pilot structured interview in Lithuanian SMEs, applying ethical codes in their activity. Limitations of empirical research are related with rather narrow research based on SMEs. But from the other side SMEs are more lacking of resources and inspiration for implementing ethical codes in their activity and this research may serve as inspiration for real actions.

\section{Conclusions}

1. Ethical code might be rather useful instrument in strong competition. Ethical codes play very important role in organizational culture and formation of microclimate as well as ethical codes have a lot of functions in enterprises and encounter relations among various interest groups of companies.

2. Lithuania has ethics supervision institutions controlling public sector. Different professionals, business groups have their own ethical codes, but overall situation in the country related with clarity

${ }^{23}$ Corresponding author - e-mail address: jolita.greblikaite@ktu.lt, phone number: +370 61644615

Jolita Greblikaite 


\section{$2\{3$ New Challenges of Economic and Business Development - 2014}

May 8 - 10, 2014, Riga, University of Latvia

of activity is not very favorable for ethical behavior. Real changes are needed in institutions and enterprises of being ethical, socially responsible, and sustainable.

3. Lithuanian SMEs have some problems implementing ethical codes in their activity, but overall effect of implementation of ethical codes in enterprises is very positive as to the enterprises themselves and society in a whole. Ethical codes in Lithuanian SMEs improve decision making, improve enterprise microclimate, prevent from conflicts, raise effectiveness, foster ethical behavior of employees, raise profitability, support co-operation, are good ethical examples, change approach to business and entrepreneurship, create image. Successful functioning of ethical codes in Lithuanian SMEs depends on developing adaption of ethical codes by employees, understandability of ethical codes, adaption of ethical code to concrete enterprise and activity, using of ethical code in everyday activity, maintenance of ethical codes by top managers.

4. Lithuania and other EU countries should use research for their enterprises and rising ethical problems there. It is very important to find common path for society, business, politicians, and educational and training institutions for developing the framework supporting ethical consciousness in overall society of country.

\section{Bibliography}

Adams, J. S., Tashchian, A., Shore, T. H. 2001. Codes of Ethics as Signals of Ethical Behavior. Journal of Business Ethics, 29, pp. 199-211.

Asgary, N., Mitschow, M. C., 2002. Toward a Model for International Business Ethics. Journal of Business Ethics, 36(3), pp. 239-246.

Bass, B. M., Steidlmeier, P., 1999. Ethics, Character, and Authentic Transformational Leadership Behavior. The Leadership Quarterly, 10, pp. 181-217.

Forsyth, D. R., O’Boyle, E. H. Jr., 2011. Rules, Standards, and Ethics: Relativism Predicts Cross-national Differences in the Codification of Moral Standards. International Business Review, 20, pp. 353-361.

Garcia-Marza, D., 2005. Trust and Dialogue: Theoretical Approaches to Ethics Auditing. Journal of Business Ethics, 57(3), pp. 209-219.

Pater, A., van Gils, A., 2003. Stimulating Ethical Decision-Making in a Business Context: Effects of Ethical and Professional Codes// European Management Journal, Vol. 21, No. 6, pp. 762-772.

Raiborn, C. A., Payne, D. 1990. Corporate Codes of Conduct: a Collective Conscience and Continuum. Journal of Business Ethics, 9, pp. 879-889.

Rodriguez-Dominguez, L., Sanchez-Garcia, I M., Gallego-Alvarez, I., 2009. Codes of Ethics in Spanish Corporations: An Exploratory Content Analysis. International Journal of Law and Management, 5(5), pp. 291-309.

Sanchez-Garcia, I. M., Rodriguez-Dominguez, L., Gallego-Alvarez, I., 2013. CEO Qualities and Codes of Ethics. European Journal of Law and Economics, 35, pp. 295-312.

Schwartz, M. S., 2005. Universal Moral Values for Corporate Codes of Ethics. Journal of Business Ethics, 59(1), pp. 27-44.

Svensson, G., Wood, G., Calllaghan, M., 2010. A Corporate Model of Sustainable Business Practices: An Ethical Perspective. Journal of World Business, 45, pp. 336-345.

Williams S., 2011. Engaging Values in International Business Practice. Business Horizons, 54, pp. 315-324.

Wotruba, T. R., Chonko, L. B., Loe, T. W., 2001. The Impact of Ethics Code Familiarity on Manager Behavior. Journal of Business Ethics, 33, pp. 59-69. 


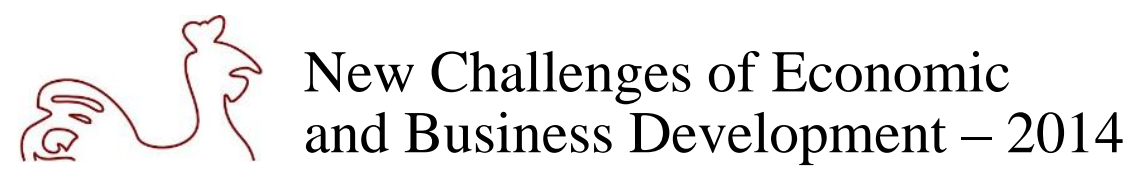

May 8 - 10, 2014, Riga, University of Latvia

\title{
ALTERNATIVE INVESTMENT FUND MANAGERS DIRECTIVE AND ITS IMPACT ON MALTA’S FINANCIAL SERVICE INDUSTRY
}

\author{
Simon Grima, University of Malta, Malta; \\ Inna Romānova, University of Latvia, Latvia ${ }^{24}$; \\ Frank Bezzina, University of Malta, Malta; \\ Frank Chetcuti Dimech, University of Malta, Malta
}

Key words: Alternative Fund Managers Directive (AIFM), competitiveness, investment fund manager

JEL codes: C23, C24

\section{Introduction}

In June 2011, the European Commission proposed a new Directive (AIFM Directive 2011/61/EU) on Alternative Investment Fund Managers (AIFM). The aim of this Directive is to establish common requirements governing the authorisation and supervision of AIFMs in order to provide a coherent approach to the related risks and their impact on investors and markets in the European Union (Directive, 2011). According to the requirements, the AIFM directive should be transposed into national law by July 22, 2013 thus establishing an EU-wide harmonised framework for monitoring and supervising risks as well as imposing more rigorous regulation on alternative investment fund managers. The AIFM Directive covers different types of alternative investment funds, e.g., hedge funds, private equity funds, real estate funds, retail investment funds, as well as alternative investment companies. Thus, this Directive means a radical transformation of the EU regulatory landscape for the whole alternative investment fund industry.

The reaction of the investment fund industry was rather equivocal. On one hand, the Directive creates a European passport system for alternative investment fund managers, thus allowing distribution of these investment funds to professional investors. On the other hand, new regulations bring additional work for alternative managers to get the processes and procedures in place, especially concerning regulatory reporting, depositary requirements, risk management and certain disclosures to investors. The impact of the Directive on the investment fund industry is still unclear. Several studies conducted by industry professionals have shown that most market participants see the AIFM Directive as a threat to their business and competitiveness of the industry in Europe (Deloitte, 2012). Besides, the Directive may put some alternative investment fund markets in a weak competitive position as an alternative fund and management company domicile.

Therefore the aim of the paper is to assess the impact AIFMD will have on AIFMs managing AIFs in Malta After over-viewing key concepts associated with the AIFMD and possible impacts of this directive on the AIF industry, this paper focuses exclusively on the Maltese fund industry. It investigates various factors that might have a positive or negative impact on the industry resulting from the AIFMD. The findings will be discussed and the study goes to provide recommendations aimed at helping the Maltese Fund Industry to develop successfully. The recommendations can be also partially applied to other investment fund domiciles.

\footnotetext{
${ }^{24}$ Corresponding author - e-mail address: inna.romanova@lu.lv, phone number: +371 67034632
} 


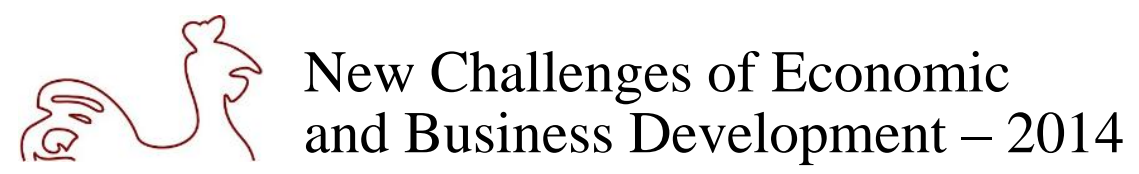

May 8 - 10, 2014, Riga, University of Latvia

\section{Methods and Preliminary Findings}

The paper investigates the following three research questions empirically: 1. Following the AIFMD, how important will specific incentives be for retaining/obtaining an AIF licence in Malta? 2. Following the AIFMD, how important will specific disincentives be for retaining/obtaining an AIF licence in Malta? 3. Does the intention to retain/obtain an AIF licence in Malta following the AIFMD vary as a function of the size of the Fund, whether the Fund Manager/Fund is already licensed in Malta and whether the Fund Manager has a licensed Fund in Malta?

To answer these questions, we targeted all players in the fund industry comprising 71 Fund Managers and 231 licenced Funds regulated and licensed by the Malta Financial Services Authority. Additionally, we targeted potential AIF licence holders; i.e., those who intend to obtain an AIF licence in Malta in the next two years (population not available). With no sampling frame available for the latter, we resorted to 'criticalcase purposive sampling' (Saunders, Thornhill, \& Lewis, 2009). All the data were gathered via a web-link on kwiksurveys.com and no incentives were offered to the participants for answering the questionnaire.

To answer the first two research questions, we started by generating descriptive statistics for each of the 11 incentives and 11 disincentives using the median $(\mathrm{Md})$, the range $(\mathrm{R})$, the mean $(\mathrm{M})$, the standard deviation (SD) and mean rank (MR). To test for difference in mean ranks across the various ordinal scales, we conducted the Friedman test. In the presence of a significant $\chi^{2}$ statistic in the Friedman test, we computed a series of Wilcoxon tests as post-hoc tests, applying the Bonferroni correction to avoid the problem of inflating the Type 1 error due to multiple comparisons (Miller, 1991). To answer the third research question, we used stepwise multiple regression. 'Intention to retain/obtain the Licence in Malta following AIFMD' was included as the dependent variable, while 'size of Fund', whether or not 'the Fund manager is already licensed in Malta' and whether or not 'the Fund manager has a licensed fund in Malta' were included as independent variables.

\section{Conclusions}

This study provides a comprehensive picture of the importance of specific incentives and disincentives for Fund Managers and Funds in obtaining or retaining an AIF licence in Malta following the AIFMD. Firstly, four specific incentives emerged as important in attracting Fund Managers and Funds to obtain/retain an AIF licence in Malta following the AIFMD; namely, lower running costs, tax incentives, the stable economic climate, and EU passporting. Secondly, three specific disincentives in obtaining/retaining an AIF Licence following the AIFMD are identified: namely, an insufficient number of custodians/depositaries, a lack of internationally established custodians/depositaries and the marketing of AIFs to non-professional investors. Thirdly, the study shows those who already have a licenced fund in Malta had a greater intention to obtain/retain an AIF licence following the AIFMD, with the size of fund and possession of a Fund manager licence not producing any impact on intention.

\section{Bibliography}

Council Directive 2011/61/EU, 2011. Directive on Alternative Investment Fund Managers and Amending Directives 2003/41/EC and 2009/65/EC and Regulations (EC) No 1060/2009 and (EU) No 1095/2010.

Deloitte, 2012. Responding to the New Reality Alternative Investment Fund Managers Directive Survey. [Online] Available at: http://www.deloitte.com/assets/Dcom-UnitedKingdom/Local\%20Assets/Docu ments/Industries/Financial\%20Services/uk-fs-aifmd-survey-responding-new-reality.pdf [Accessed 10 January 2014].

Miller, R. G., 1991. Simultaneous Statistical Inference. New York: Springer-Verlag.

Saunders, M., Lewis, P. \& Thornhill, 2012. A. Research Methods for Business Students. Pearson, Harlow. 


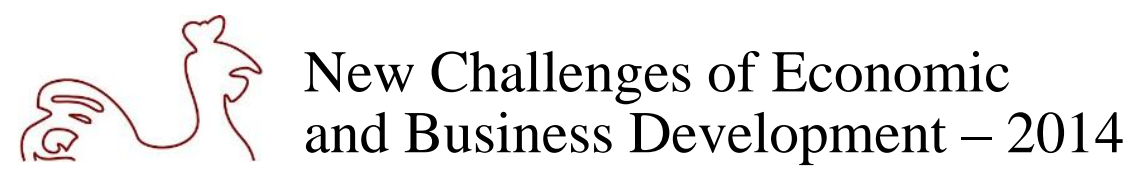

May 8 - 10, 2014, Riga, University of Latvia

\title{
ASSESSMENT OF PREPAREDNESS TO LEAN SIX SIGMA PROJECTS IN SMALL AND MEDIUM-SIZED ENTERPRISES
}

\author{
Piotr Grudowski, Gdansk University of Technology, Poland ${ }^{25}$; \\ Malgorzata Wisniewska, University of Gdansk, Poland
}

Key words: small and medium-sized enterprises, concept of Lean Six Sigma, quality management

JEL code: L53

\section{Introduction}

There are many reasons that oblige SMEs to apply a continuous improvement principle: either as a necessity to adapt to the changing market, a need for development and competitiveness or a demand for using modern management methods as a condition of cooperation from their clients - large companies. The key principle of quality management - customer focus, materializes, first of all, thanks to a reduction in the variation of the processes most important from the customer's point of view - called Critical To Quality (CTQ) [Antony, Escamilla, Caine, 2003, p. 40-42 [Linderman, Schroeder, Zaheer, Choo, 2003, p. 193-203], [Gowen, Tallon, 2005, p. 59-87].

These requirements may be met by using the hybrid Lean Six Sigma concept adapted to the specificities of small and medium-sized enterprises, such as a lack of financial resources, qualifications, time available and also a low level of sector maturity. The mentioned conditions and the choice of functional and flexible tools for SMEs were specified in detail in the publications by P. Grudowski and E. Leseure [Grudowski, Leseure, 2010, p. 121-130] as well as by P. Grudowski, E. Zajkowska, M. Bigand and E. Castelain [Grudowski, Zajkowska, Bigand, Castelain, 2009, p. 276-281].

In the case of SMEs, the application of the concept of Lean Six Sigma is so far much less common than in large organizations. This is evidenced by the scarce literature on the subject.

The main objective of the paper is to present the diagnostic method useful in the profiled adaptation of Lean Six Sigma and its implementation in small and medium-sized enterprises of the manufacturing sector. The aim of the method therefore is the determination of the level of maturity of a smaller organization to implement a Lean Six Sigma project.

\section{Methods and results}

According to the results of pilot research conducted by the authors among industrial SMEs in Poland and France between the years 2009 and 2011 (18 SMEs from different sectors - 9 Polish and 9 French) there is a significant difference between the expectations, problems and limitations within this group of organizations. Most small firms (<50 employees) quickly and effectively respond to changes in the market, having, unfortunately, low-quality culture and requiring simple and easy-to-implement solutions development. Midsize organizations (less than 250 employees) represent a similar quality maturity level to large organizations with regard to modern methods of management, appropriate ground for cultural issues of production management and improvement of quality, and the time and financial resources available to achieve strategic objectives.

In order to take into account these differences, the authors propose the maturity indicator of LSS projects within the framework of the original comprehensive methodology of Lean Six Sigma

\footnotetext{
${ }^{25}$ Corresponding author - e-mail address: pgrudows@pg.gda.pl, phone number: +(48) 501935080
} 


\section{$\left\{\begin{array}{l}3 \\ 5\end{array}\right.$ New Challenges of Economic and Business Development - 2014}

May 8 - 10, 2014, Riga, University of Latvia

implementation, dedicated to the SME sector. The indicator allows the range of the LSS project to be matched to the real needs and preparedness of any small or medium-sized organization. The indicator is based on 8 groups of evaluation criteria divided into two categories: "Needs" and "Capabilities". Considering the relationship between the states of these two categories, one can establish the level of readiness of a smaller organization to conduct an LSS improvement project, selecting the adequate set of methods, techniques and tools.

\section{Conclusions}

As a result of practical verification in selected smaller Polish and French organizations, the authors may confirm the positive complementary impact of Lean Management and Six Sigma methodologies on the performance of SMEs. The proposed maturity indicator of an SME to an LSS project turned out to be very useful in defining both the scope of the LSS project and the repository of the most effective methods, techniques and tools applied in the project. Another important aspect of the indicator is its applicability in the service sector, where, for example, the number of defect products may be replaced by the number of errors in the financial statement or a manufacturing cycle time by a reparation period. This, in turn, emphasizes the universal aspect of the original methodology developed by authors to improve the functioning of SMEs in the various sectors of industry.

\section{Bibliography}

Antony J., Escamilla J. L., Caine P., 2003. Lean Sigma [production and supply chain management], Manufacturing Engineer, No. 2.

Linderman K., Schroeder R. G., Zaheer S., Choo A. S., 2003. Six Sigma: a goal-theoretic perspective, Journal of Operations Management, No. 2.

Gowen C. R. III, Tallon W. J., 2005. Effect of technological intensity on the relationships among Six Sigma design, electronic-business, and competitive advantage: A dynamic capabilities model study, The Journal of High Technology Management Research, No. 1.

Grudowski P., Leseure E., 2010. Model integracji koncepcji Lean Management z metodyką Six Sigma w sektorze MŚP, in: Doskonalenie produktu i przedsiębiorstwa na tle problemów towaroznawczych, Wiśniewska M., Malinowska E., Szymańska-Brałkowska M. (red.), Prace i Materiały Wydziału Zarządzania Uniwersytetu Gdańskiego, Sopot.

Grudowski P., Zajkowska E., Bigand M., Castelain E., 2009. Wdrażanie Lean Six Sigma w MŚP sektora produkcyjnego, in: Inżynieria jakości w produkcji, usługach i sektorze publicznym, Grudowski P., Dobrzyński M., Preihs J., Waszczur P. (red.), Wydawnictwo Politechniki Gdańskiej, Wydział Mechaniczny, Katedra Technologii Maszyn i Automatyzacji Produkcji, Gdańsk. 


\title{
$\left\{\begin{array}{l}3 \\ 5\end{array}\right.$ New Challenges of Economic and Business Development - 2014
}

May 8 - 10, 2014, Riga, University of Latvia

\section{WEB-BASED RESOURCES AS FINANCIAL LITERACY IMPROVEMENT TOOL}

\author{
Ksenija Ijevleva, University of Latvia, Latvia ${ }^{26}$; \\ Ilja Arefjevs, BA School of Business and Finance, Latvia
}

Key words: Financial literacy, banks, web-based resources

JEL codes: G02, G20, M31

\section{Introduction}

In recent years consumers have become more active in financial markets along with the appearance of variety of new financial services and products. Market liberalization in Baltic countries has caused an ongoing shift of a decision-making responsibility away from the government toward private consumers. However, the pivotal question is whether individuals possess sufficient financial literacy, knowledge and experience to demonstrate sound financial behaviour. There has been a lot of studies on this problem and the few existing researches indicate that individuals lack financial illiteracy of even the most basic financial aspects and their knowledge is widespread (Van Rooij et al, 2011b; Gustman et al., 2011; Klapper et al., 2013). The existing literature on financial literacy also shown that individuals who are not financially literate, on average, are less likely to care for retirement and to amass wealth (Van Rooij et al., 2011a) and are more likely to obtain high-interest loans (Bucks and Pence, 2008). Even though definitions of financial literacy vary, authors have chosen the one developed by Czech researchers Klínský and Chromá, 2009, which has clear economic anchoring. The financial literacy is considered to possess three components: monetary (cash and other money management), price (understanding of pricing and inflation) and budget literacy (personal budgeting capability).

Recent trends suggest that not only a number of internet users is increasing, but also a proportion of intertnetbanking users is. According to Eurostat data, $73 \%$ of internet users in Estonia used were also internetbanking users, 55\% of Latvian internet users used internetbanking and $46 \%$ of Lithuanian internet users were also internetbanking users in 2013.

Provided a lack of financial literacy of customers and increasing use of internet nowadays, the aim of the research is to assess to what extent content of current web-based resources, which are available in local languages, matches defined components of financial literacy of customers. The tasks of the research are to analyse and define components of financial literacy of customers, study both local open web-based and internetbanking related financial literacy resources in Estonia, Latvia and Lithuania, assess content of these resources from the financial literacy perspective and draw conclusions about match of the studied resources content with the defined components of financial literacy of customers. The research period is October-December, 2013.

\section{Methods and results}

Authors conducted a study on open web-based local resources in Estonia, Latvia and Lithuania. The open web-based resources were classified by authors in terms of their topic coverage whether there are universal or specialized (eg., investments, retirement etc.). According to the findings, each country has

${ }^{26}$ Corresponding author - e-mail address: kijevleva@inbox.lv, phone number: +371 26814932 


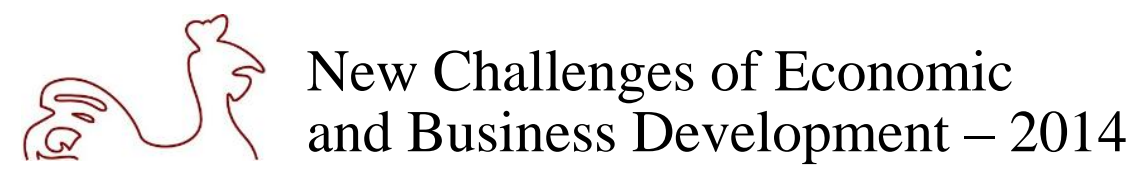

May 8 - 10, 2014, Riga, University of Latvia

two universal open-web based resources while others are specialized and mostly are dedicated to savings and retirement topics. In all three countries one of these universal web-based resourced is backed by a local financial supervision authority while another by local daughter companies of Swedbank AB. Further resources were classified in terms of financial literacy areas they are supposed to cover- price, monetary or budget. Authors conclude that they have not found any local web-based resource, which would address the price area of the customers' financial literacy while a number of resources are addressing other areas of financial literacy only partly. Thus, there is clearly potential for further content improvement in open web-based resources in relation to partly addressed or unaddressed areas of customers' financial literacy.

Authors also study internetbanking related financial literacy resources to find out whether online financial planning tools are available in internetbanking platforms of banks or not. According to findings, only internetbanking platforms run by local daughter companies of Swedbank $\mathrm{AB}$ offers a financial planning tool for customers. Thus, authors consider that there clearly space to improve financial literacy of customers by providing online financial planning tools built into internetbanking platforms. This conclusion is also supported by findings of the regression analysis, which suggest that for both Latvia and Estonia nine out of ten new banking customers are using internetbanking services (adjusted R-squared exceeds 0.96, significance below 0.001) and internetbanking users were discovered to be marginally higher correlated with a number of complaints that all banking customers.

\section{Conclusions}

Many researches suggest that financial literacy of customers needs to be improved substantially. According to the study by authors, local web-based resources in Estonia, Latvia and Lithuania provide coverage of monetary and budget related financial literacy only partly while none of them addresses the price literacy related topics. Thus, there is clearly potential for further content improvement in open webbased resources to achieve a broader coverage of financial literacy items as well as include the price literacy perspective, which was not covered.

Furthermore, authors conclude that nine out of ten new banking customers are using internetbanking services in both Latvia and Estonia. However, only internetbanking platforms run by local companies of Swedbank AB offer a financial planning tool for customers leaving space for other banks to support personilized budgeting financial literacy in the similar manner.

\section{Bibliography}

Bucks B., Pence K., 2008. Do Borrowers Know Their Mortgage Terms? Journal of Urban Economics, 64, pp. 218-233.

Eurostat, 2013. Individuals using the Internet for Internet banking. [Online] Available at: http://epp. eurostat.ec.europa.eu/tgm/table.do $?$ tab=table\&plugin $=1 \&$ language $=$ en \&pcode $=$ tin00099 $\quad$ Accessed 1 February 2013].

Gustman A.L., Steinmeier T.L., Tabatabai N., 2012. Financial Knowledge and Financial Literacy at the Household Level. American Economic Review Papers and Proceedings, 102, pp. 309-313.

Klapper L., Lusardi A., Panos G. A., 2013. Financial Literacy and its Consequences: Evidence from Russia during the Financial Crisis. Journal of Banking \& Finance, 37, pp. 3904-3923.

Klínský P., Chromá D., 2009. Finanční gramotnost-úlohy a metodika. Praha, Czechia: Národní ústav odborného vzdělávání. Národní strategie finančního vzdělávání.

Van Rooij M., Lusardi A., Alessie R., 2011. Financial Literacy and Stock Market Participation. Journal of Financial Economics, 101, pp. 449-472.

Van Rooji M., Lusardi A., Alessie R., 2011. Financial Literacy and Retirement Planning in the Netherlands. Journal of Economic Psychology, 32, pp. 593-608. 


\title{
$2\left\{\begin{array}{l}3 \\ 5\end{array}\right.$ New Challenges of Economic and Business Development - 2014
}

May 8 - 10, 2014, Riga, University of Latvia

\section{TEACHING AND LEARNING IN, WITH AND THROUGH ENTREPRENEURSHIP: LESSONS LEARNED FROM AN EXPERIMENT IN SOCIO-CULTURAL ENTREPRENEURSHIP EDUCATION}

\author{
Valentyna Ilgenayeva, Kharkiv State Academy of Culture, Ukraine; \\ Hans Elbeshausen, University Copenhagen, Denmark ${ }^{27}$
}

Key words: entrepreneurship; teaching entrepreneurship; process models

JEL code: L26

\section{Introduction}

The paper examines a number of experimental courses that have entrepreneurship as content and method. The experiments have spanned over four years and have been conducted at a higher education institution (HEI) where graduates are trained in communication, conveyance of culture, information architecture and information management. In our paper we focus especially on didactic and pedagogic perspectives of entrepreneurship education.

There have been many conflicting suggestions about entrepreneurship education. David Birch does not believe that you can teach people to be entrepreneurs (Aronsson 2004). Sarasvathy and Venkataraman are, on the contrary, convinced that entrepreneurship should be treated as an essential part of basic education, which "means starting in middle school or earlier and excluding no one" (2011). At present it looks like as if the advocates of academisation and school-like teaching have won recognition - mainly for political reasons as Paul Hannon (2005) underlines.

From a systematic view entrepreneurship education can be divided into at least three main areas.

- Entrepreneurship as part of managerial or strategic concept; the educational focus is then on rationality and strategic reasoning.

- Entrepreneurship works as a process of creation; the major focus will be put on the creative capacities of the individual.

- Entrepreneurship can be thought of as generalized method, i.e. a form of reasoning and logic (Sarasvathy \& Venkataraman 2011) or everyday practice (Blenker et al. 2012)

Our contribution discusses in particular the question of how process models, prevalent in the third approach to entrepreneurship education, interact with learning in and through practice. The background for the article is the fact that approx. $75 \%$ of the projects and seminar papers, the students have worked on, have been within the domain of "socio-cultural" entrepreneurship. The remaining $25 \%$ have either been about intrapreneurship, i.e. employee-driven innovation, or general market-oriented entrepreneurship. The aim of the article is therefore to examine and discuss whether process models for entrepreneurship education are viable and suitable in the socio-cultural domain or whether they need to be adapted even better to the specific structure and processes of the field under investigation.

\section{Methods and results}

In 2000 Shane \& Venkataraman presented a new concept that clarifies the basic idea for research activities in entrepreneurship. The concept became known as individual-opportunity nexus. By defining

${ }^{27}$ Corresponding author - e-mail address: he@iva.dk 


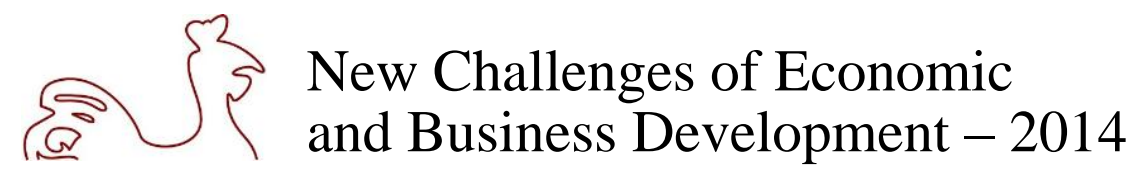

May 8 - 10, 2014, Riga, University of Latvia

entrepreneurship as a situational process where entrepreneurs, based on their individual resources, abilities and skills, create and exploit profitable opportunities hitherto prevailing models and methods in entrepreneurship education have to be renewed too.

The discovery and exploitation of new opportunities or the solution of anomalies has become the new nucleus of entrepreneurial teaching. The aim is to provide tools for students that assist in the navigation and development of paths characterized by uncertainty and unpredictability. Honig integrates those supporting tools into a model, which he describes as contingency approach (2004). We agree in the overall assumption made in the contingency approach, which says that teaching and learning cannot be planned as causal and linear processes if the starting point is uncertainty. But the approach has some limitations. Therefore other theories must be taken into consideration too (Engeström 2004, Löbler 2006).

Based on a series of teaching experiments (Elbeshausen et al. 2012) carried out as compulsory MA-courses at a HEI we analyze three process models in regard to the contingency approach: 1) a creativity model, where creativity and innovation is at the heart of the teaching activities; 2) a collaboration model with focus on the deconstruction of monodisciplinary approaches and the construction of relational configurations; 3) finally the "logic of effectuation" introduced by Sarasvathy. Analytically, these models are compared with a view to action-learning and to the acquisition of new knowledge and skills in the field of socio-cultural and ordinary entrepreneurship.

\section{Conclusion}

Overall, one can say that the process models have helped students to discover, to structure and develop personal as well as relational resources when it comes to creating opportunities or to performing innovative actions in given projects. Concerning the various objectives of teaching entrepreneurship each of the models has strengths and weaknesses. This means that none of the models alone can assist in the invention of road maps for territories characterized by uncertainty and unpredictability. Nevertheless, the three process models have a general weakness in common. They do not promote a deeper understanding of specific challenges related to cultural and social entrepreneurship. It seems plausible to assume that the models have their highest explanatory power in terms of economic rationality and need to be modified when entrepreneurial projects are concerned with social and cultural issues.

\section{Bibliography}

Aronsson, M. 2004. Education matters - but does entrepreneurship education? An interview with David Birch. Academy of Management Learning \& Education, 3(3), 289-292.

Blenker, P. et al., 2012. Entrepreneurship as everyday practice: towards a personalized pedagogy of enterprise education. Industry and Higher Education 26, No. 6, pp. 417-430.

Elbeshausen, H. et al., 2012. Tag en bid af praksis: Pædagogisk værktøj til entreprenørskabsundervisning i praksis indenfor informationsvidenskab og kulturformidling.

Engeström, Y. 2004. New forms of learning in co-configuration work. Journal of Workplace Learning, 16(1/2), pp. 11-21.

Hannon, P.D., 2005. Philosophies of enterprise and entrepreneurship education and challenges for higher education in the UK. The International Journal of Entrepreneurship and Innovation 6, No. 2, pp. 105-114.

Honig, B., 2004. Entrepreneurship education: toward a model of contingency-based business planning. Academy of Management Learning \& Education 3, No. 3, pp. 258-273.

Löbler, H. 2006. Learning entrepreneurship from a constructivist perspective. Technology Analysis \& Strategic Management, 18(1), pp. 19-38.

Sarasvathy, S.D. \& Venkataraman, S., 2011. Entrepreneurship as method: Open questions for an entrepreneurial future. Entrepreneurship Theory and Practice 35, No. 1, pp. 113-135.

Shane, S. \& Venkataraman, S., 2000. The promise of entrepreneurship as a field of research. Academy of management review 25, No. 1, pp. 217-226. 


\title{
$\left\{\begin{array}{l}3 \\ 5\end{array}\right.$ New Challenges of Economic and Business Development - 2014
}

May 8 - 10, 2014, Riga, University of Latvia

\section{DIFFICULTIES WITH INNOVATION STATISTICS: SOME KEY ISSUES}

\author{
Svetlana Jesiḷevska, University of Latvia, Latvia ${ }^{28}$
}

Key words: innovations statistics, data quality, methodology, economic growth

JEL codes: O10, C10

\section{Introduction}

For effective decision-making the statistical data on innovations is essential. Innovation statistics is of much more than theoretical interest. Great amounts of social resources on education, science and technology are spent in the belief that these support innovation, and that innovation is the key to economic growth. The EU data show that Latvia's innovation performance is one of the lowest among the Baltic States.

Confidence in the quality of the statistical data is a survival issue for a statistical office. If its information becomes distrustful, the reputation of the statistical office is called into question. Regular methodological changes as well as globalisation complicate the generation of innovation statistics. Two key things national statistical offices need to do are to increase the relevance of statistical frameworks, standards and classifications to contemporary issues and to work out a way to more rapidly evolve technology infrastructures. The problem is associated not only with selecting appropriate criteria by which to evaluate the goodness of statistical data on innovations, but also on existing methodology and the understanding of innovation and the significance of innovation statistics held both by statisticians and innovation survey participants. The concept of innovation is interpreted differently among statisticians, economists and entrepreneurs and this often causes inaccuracy in innovation data. The reasons for difficulty in the producing of accurate innovation statistics are to do not only with failures in the interpretation of the concept of innovation, but also with the complexity and dynamism of the innovation process.

Quality is not an easily defined concept, and has become an over-used term in recent years. The fact that there are so many possible definitions for the term "data quality" and plenty of data quality indicators suggest that it is a common concept relative to the researcher and belief system for which it stems. This paper aims to discuss the most common problems that make significant impact on the quality of innovation statistics and to propose an approach for determining innovation data quality.

\section{Methods and results}

The theoretical and methodological evidence of this paper is based on the analysis of the economic literature, scientific works published by Latvian and foreign scientists; the legal documents of European Commission; the statistics database of the Central Statistical Bureau of Latvia; Eurostat and other international statistical and methodological materials. Bibliography review, as well as methods of statistical analysis such as grouping, processing and comparative analysis has mainly been used in the paper.

Statistics on innovation are extremely important as creativity and innovation is a core competency for leaders and managers. Generating fresh solutions to problems, and the ability to create new products, processes or services for a changing market and new world are part of the intellectual capital that gives a

${ }^{28}$ Corresponding author - e-mail address: mozir@inbox.lv, phone number: +371 27603109

Svetlana Jesil̦evska 


\section{$\left\{\begin{array}{l}\left\{\begin{array}{l}\text { New Challenges of Economic } \\ \text { and Business Development }-2014\end{array}\right.\end{array}\right.$}

May 8 - 10, 2014, Riga, University of Latvia

company its competitive edge. Creativity is a crucial part of the innovation equation. The Central Statistical Bureau of Latvia (CSB) collects data on innovation activities within business enterprises in Latvia on a regular basis, using a methodology supplied by Eurostat (Jesilevska, 2012).

Author developed a system of innovation statistical data collecting and processing and identified various problems of this process at the every stage of data collecting and processing in the context of Latvia.

Since all types of research must respond to the agreed canons of quality (Marshall and Rossman 2006), we cannot avoid discussing them, in spite of their philosophical and practical complexity as well as the difficulty in defining what quality actually means or covers. Nowadays there are multiple different ways to define data quality and there is currently no commonly agreed definition on what data quality is. Different analysts and different agencies provide different answers (Brackstone 1999, Carson 2000, Pipino et al. 2002), but all agree that "data quality" is a multidimensional concept.

As a result author propose the following systematic approach for determining innovation data quality that contains the following characteristics of quality: Validity (reliability; accuracy; representativeness; adequacy and substantiated nature of a measuring instrument; objectivity); Comparability; Completeness; Coherence; Understandability/interpretability/clarity of the data; Complexity; Flexibility; Timeliness/actuality in disseminating results; Utility/importance; Informativeness; Sensitivity.

\section{Conclusions}

In this paper author developed a system of innovation statistical data collecting and processing and identified various problems of this process at the every stage of data collecting and processing. Author identified the following problems in the context of quality of innovation statistics: lack of a common understanding and a harmonisation of the innovation process, lack of co-operation between statisticians and respondents, difficulties to motivate enterprises to provide correct and accurate data, methodological difficulties, lack of understanding of the significance of the interpretation of statistical information as an integral part in the planning process of innovation policy etc. As a result the quality of innovation statistics should be improved.

Author propose the following systematic approach for determining innovation data quality that contains the following characteristics of quality: Validity (reliability; accuracy; representativeness; adequacy and substantiated nature of a measuring instrument; objectivity); Comparability; Completeness; Coherence; Understandability/interpretability/clarity of the data; Complexity; Flexibility; Timeliness/actuality in disseminating results; Utility/importance; Informativeness; Sensitivity.

\section{Bibliography}

Brackstone, G., 1999. Managing Data Quality in a Statistical Agency. Survey Methodology, 25, pp. 139-149.

Carson, C. S., 2000. What is Data Quality? A Distillation of Experience. Statistics Department, International Monetary Fund.

Jesil̦evska, S., 2012. Methodological aspects of innovation statistics and innovativeness of Latvia. Lithuanian Journal of Statistics, 51(1), pp. 57-65.

Marshall, C. \& Rossman, G.B., 2006. Designing Qualitative Research (4 ed.). Thousand Oaks, CA: Sage. Pipino, L. L., Lee, Y. W., \& Wang, R. Y., 2002. Data Quality Assessment. Communications of the ACM, 45, pp. 211-218. 


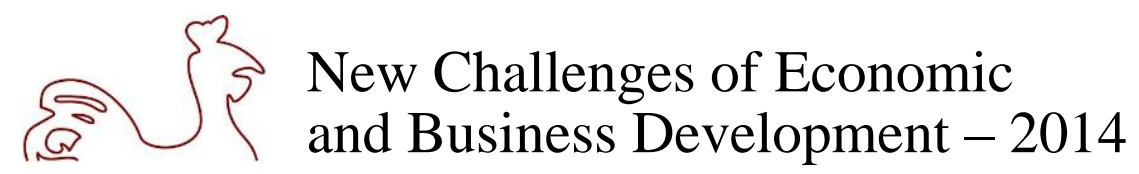

May 8 - 10, 2014, Riga, University of Latvia

\title{
THE METHODOLOGY OF MEASUREMENT OF OBJECTIVE WELL-BEING IN MUNICIPALITIES: CASE OF LATVIA
}

\author{
Inga Jēkabsone, University of Latvia, Latvia ${ }^{29}$; \\ Biruta Sloka, University of Latvia, Latvia
}

Key words: objective well-being, municipality, index, methodology

JEL codes: B41, H75, R58

\section{Introduction}

Traditionally, the nation's well-being is measured by objective macroeconomics indicators like GDP or GNP. However, well-being is more than the accumulation of material wealth, it is a complex concept which contains many features, e.g. economic, social, and environmental. At the same time, the local government is becoming more and more important nowadays regarding ensuring the well-being of their communities, thereby it is important to measure well-being at local level. The research question: "What is the optimal research methodology for measurement of objective well-being at local level?". To develop the methodology for measurement of objective well-being there would be conducted research of existing objective well-being evaluation and measurement methodologies for municipalities, accordingly would be proposed the methodology of measurement of well-being at local level. In addition there would be approbated proposed methodology for Latvian municipalities for 2012.

The aim of the paper is to develop and approbate research methodology for measurement of objective wellbeing at local level. In order to achieve the aim, the tasks are formulated as follows: 1) to conduct a research of existing methodologies for evaluation and measurement of well-being at local level; 2) to develop the research methodology for measurement of objective well-being for municipalities; 3) to approbate developed methodology for measurement of objective well-being for Latvian municipalities; 4) to provide proposals for using the developed methodology for measurement of objective well-being for Latvian municipalities.

The proposed methodology for measurement of objective well-being for municipalities would be innovative at national level, as there hadn't been developed a system for evaluation and measurement of objective well-being at municipal level in Latvia.

\section{Methods and results}

Among social researchers there is confidence that well-being is complex concept which could be evaluated using measurable indicators (Rinne et. al., 2013; Hezri, 2004, Bauler, 2012; Rydin et. al., 2003). One of the approach for measuring well-being is developing indexes which allows to include different indicators in one index (Briec et. al., 2013; Smith et. al., 2013; Osberg \& Sharpe, 2009). Based on those observation there would be developed index for measuring objective well-being at local level adopted for municipalities of Latvia. In order to develop this index, at the beginning there would be selected indicators of well-being measured at local level - the evaluation and selection of indicators would be based on expert evaluation. Pilot expert survey has been conducted to test the approach. Among the experts high level professionals and researchers are invited. Afterwards the values of selected indicators would be standardized and there would be given certain significant weight for indicators. In the end there would be determined the value and rank of objective well-being index for Latvian municipalities for 2012 (see Figure 1).

${ }^{29}$ Corresponding author - e-mail address: jekabsone_inga@ inbox.lv, phone number: +371 27116147 


\section{\{ $\{$ New Challenges of Economic and Business Development - 2014}

May 8 - 10, 2014, Riga, University of Latvia

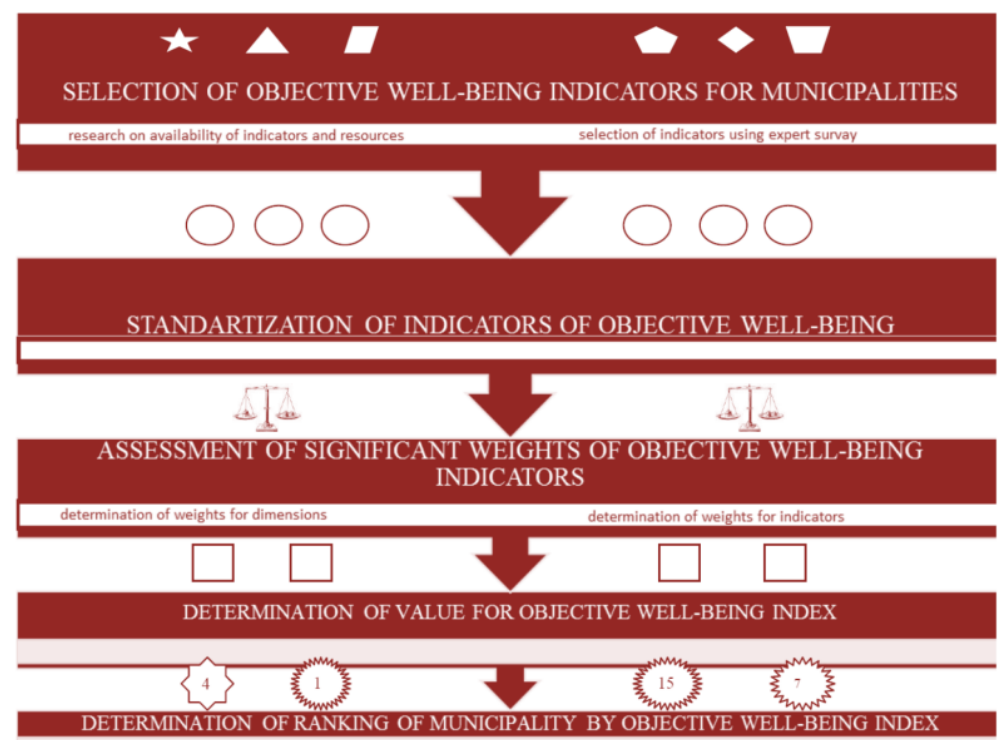

Source: Inga Jēkabsone's construction.

Fig. 1. Estimation steps for objective well-being index for municipalities

Research results showed that the objective well - being index for municipalities could be practically used for decision making.

\section{Conclusions}

The main conclusions of the scientific papers published worldwide are closely related to the accepted concept of using different indicators for measuring well-being - conducted research showed that one of the most reasonable approaches how to evaluate objective well-being is developing index which contains several features of well-being concept. This approach could also be adopted at local level accordingly to the growing importance of municipalities in promoting well-being for society. The main results of the paper - developed methodology and practical test of the methodology for measuring objective well-being at local level approbated for Latvian municipalities for 2012. The main findings of paper contribute to the discipline of public administration providing reach data for national, regional and local decision makers.

\section{Bibliography}

Bauler, T., 2012. An analytical framework to discuss the usability of (environmental) indicators for policy. Ecological Indicators, 17, pp. 38-45.

Briec, W., Dumas, A., Stenger, A., 2013. On the standard achievement and well-being indexes and their relation to the Hicks-Moorsteen productivity index. Economic Modelling, 35, pp. 900-909.

Hezri, A.A., 2004. Sustainability indicator system and policy processes in Malaysia: a framework for utilisation and learning. J. Environmental Manage, 73, pp. 357-371.

Osberg, L., Sharpe, A., 2009. New estimates of the index of economic well-being for selected OECD countries, 19802007. Centre for the Study of Living Standards (CSLS) Research Report 2009-11. Ottawa, Ontario, Canada.

Rinne, J., Lyytimäki, J., Kautto, P., 2013. From sustainability to well-being: Lessons learned from the use of sustainable development indicators at national and EU level. Ecological Indicators, 35, pp. 35-42.

Rydin, Y., Holman, N., Wolff, E., 2003. Local sustainability indicators. Local Environment, 8, pp. 581-589.

Smith, L. M., Case, J. L., Smith, H. M., 2013. Relating ecosystem services to domains of human wellbeing: Foundation for a U.S. index. Ecological Indicators, 28, pp. 79-90. 


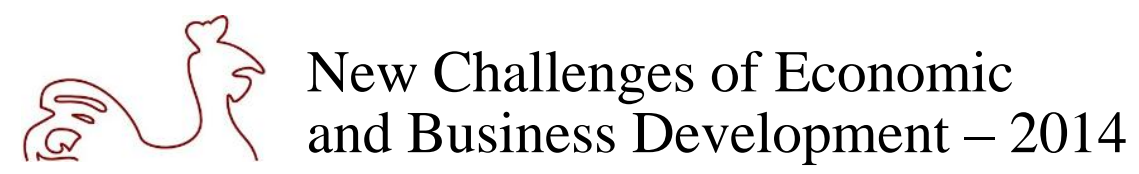

May 8 - 10, 2014, Riga, University of Latvia

\title{
THE ROLE OF ORGANIZATIONAL CULTURE IN INNOVATIVE PERFORMANCE OF SMALL AND MEDIUM-SIZED KNOWLEDGE-INTENSIVE COMPANIES IN THE BALTIC STATES
}

\author{
Madara Kairiša, University of Latvia, Latvia ${ }^{30}$
}

Key words: organizational culture, innovations, Baltic States

JEL code: M14

\section{Introduction}

Nowadays the knowledge-based economy and fierce competition puts high demands for companies - it requires continuous learning, improvement process and only those companies can be successful that can offer the newest and most unique products. There is a belief that innovations are the main aim of any organization. In addition, many studies have revealed the significant role of innovations in company performance.

Organizational culture is recognized as one of the most important factors influencing innovations. It encourages employees' innovative behavior and creation of innovations. In order to create continuous and sustainable values, companies must develop and implement the innovation culture that allows creation of capabilities necessary to compete successfully now and in the future (March-Chorda I., 2011).

Assumption, that a certain type of organizational culture provides better performance, is one of the reasons that explain the great interest in it. Moreover, in nowadays fierce competition when companies within the same industry have access to the same resources, technologies and other factors, the organizational culture can serve as a competitive advantage. In literature the link between organizational culture and company performance is examined in different aspects, however the relationship still isn't scientifically established (Ilies L., 2008). Most of the previous studies have focused more on the research of individual elements of organizational culture and have focused mostly on traditional sectors of economy such as manufacturing, not viewing dynamic and knowledge-based industries where organizational culture can play a key role in productivity and quality promotion.

The aim of this paper was set to examine the role of organizational culture in innovative performance of small and medium-sized knowledge-intensive companies in the Baltic States and two hypotheses were proposed: H1: Adhocracy promotes the innovative performance of small and medium-sized IT companies in the Baltic States; and H2: Hierarchy hinders the innovative performance of small and medium-sized IT companies in the Baltic States.

\section{Methods and results}

In this study the Competing Values Framework (Organizational Culture Assessment Instrument), developed by Cameron and Quinn, was used for diagnosis of organizational culture types. The method classifies organizational culture into four types - Clan, Hierarchy, Market and Adhocracy. Comparing to other models, it has shown better validity rates and it is one of the most common methods used for determination of organizational culture (Cameron K., 2004).

To determine the innovative performance of companies, the innovative company indicators made by Latvian Technology Centre were used. The author added an innovation coefficient that made possible to compare various companies with each other.

The study covered 27 small and medium-sized IT companies from the Baltic States. IT companies were selected because the impact of an organizational culture is more visible within one sector and

\footnotetext{
${ }^{30}$ Corresponding author - e-mail address: madara.kairisa@ gmail.com, phone number: +371 26335371
} 


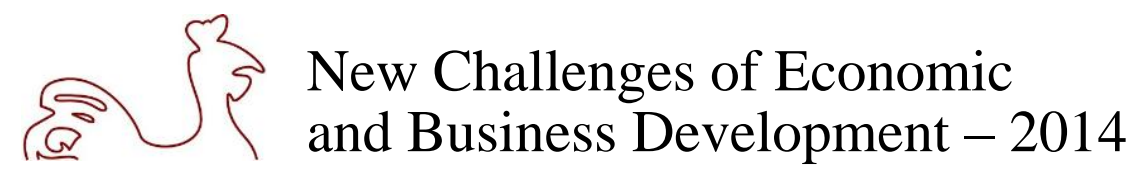

May 8 - 10, 2014, Riga, University of Latvia

because the information technologies is knowledge-intensive industry, where the organizational culture may have a significant impact on employees, their capabilities, knowledge, creativity and activity, and in result it may significantly affect the company's innovative capacity.

The research results reveal a statistically significant relationship between the innovation coefficient and adhocracy $(\mathrm{r}=0.831, \alpha=0.01)$, statistically significant negative relationship between innovation coefficient and market culture $(r=-0.581, \alpha=0.01)$ and statistically significant negative relationship between innovation coefficient and hierarchy $(\mathrm{r}=-0.620, \alpha=0.01)$. Based on these results it is possible to draw conclusions that adhocracy has a positive impact on the innovation coefficient, while market culture and hierarchy reduces it. However it must be noted that correlation between mutual culture types reduces the statistical significance of the hierarchy and market culture impact on innovative performance. These types had stronger correlation with each other rather than coefficient.

The regression analysis shows that the Pearson correlation coefficient $\mathrm{R}=0.833$, which means that there is a close relationship between the four organizational culture types and innovation coefficient. Furthermore, the coefficient of determination $\mathrm{R}^{2}=0.694$, which indicates that $69.4 \%$ of actual fluctuations of innovation coefficient around the mean coefficient, is explained by four types of organizational culture.

\section{Conclusions}

In conclusion, the innovative performance of small and medium-sized Baltic States' IT companies is promoted by adhocracy, as there was strong statistically significant positive correlation between innovation coefficient and adhocracy. In turn, the hypothesis that hierarchy hinders the companies' innovative performance is confirmed partly - there was no statistically significant relationship between innovation coefficient and hierarchy. However, hierarchy tended to have a negative impact on coefficient, also strong statistically significant negative impact on adhocracy was revealed.

Similar results were obtained by other authors. Research carried out in electronics, automotive and retail companies in Japan, China, Slovakia, Czech Republic and Russia reveals that the innovative climate in surveyed countries is fostered by adhocracy, while hierarchy does not lead to innovative climate within an organization in any of the countries investigated (Alas R. et al., 2012). Study in Japanese companies showed that the best performing companies have an adhocracy culture type while hierarchy showed poor performance (Deshpande R. et al., 1993). Also study in Spanish manufacturing companies reveals the positive impact of adhocracy on innovation orientation (Naranjo-Valencia J.C. et al., 2011). NaranjoValencia states that flexibility-oriented cultures encourage innovation occurrence since independence and freedom fosters creativity, which is a key to innovation creation, while rules, regulations, control and weak employee involvement limits the ability of participants to take innovation risks.

\section{Bibliography}

Alas, R., Ubius, U., Gaal, M.A., 2012. Predicting Innovation Climate Using Competing Values Model. Procedia - Social and Behavioral Sciences, No. 62, pp. 540-544.

Cameron, K., 2004. A Process for Changing Organizational Culture. University of Michigan Business School: To be published in M.Driver "The handbook of organizational development", $18 \mathrm{p}$.

Deshpandé, R., Farley, J.U., Webster, F.E., 1993. Corporate Culture, Cutomer Orientation, and Innovativeness in Japanese Firms: A Quadrad Analysis. The Journal of Marketing, Vol. 57, No. 1, pp. 23-37.

Ilies, L., Gavrea, C., 2008. The Link Between Organizational Culture and Corporate Performance. An Overview. Annals of University of Oradea Faculty of Economics, Vol. 4, Issue 1, pp. 322-325.

March-Chorda, I., Moser, J., 2011. How Organisational Culture Affects Innovation in Large Sized ICT Firms: A Pilot Study. Universitat de Valencia, OLKC, 20 p.

Naranjo-Valencia, J.C., Jimenez, D., Sanz-Valle, R., 2011. Innovation or Imitation? The Role of Organizational Culture. Management decision, Vol. 49, No. 1, pp. 55-72. 


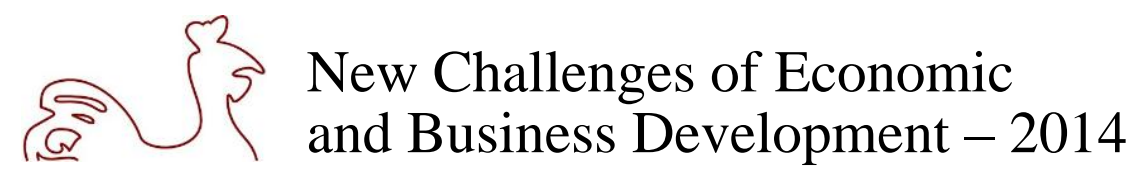

May 8 - 10, 2014, Riga, University of Latvia

\title{
EVALUATION OF WIND ENERGY INVESTMENT PROJECT
}

\author{
Rasa Kanapickienė, Vilnius University, Lithuania ${ }^{31}$; \\ Arvydas Kanapickas, Vytautas Magnus University, Lithuania
}

Key words: capital budgeting, project valuation, wind energy

JEL code: G31

\section{Extended abstract}

Households are one of the potential operators of wind power projects. However, present studies do not pay enough attention to the analysis of these projects. There are number of works which are focused exclusively on the financial evaluation of large wind power generators parks. The novelty of the present research lies in that the distribution map of the internal rate of return (IRR) of household wind power projects in Lithuania has been drawn.

\section{Introduction}

The EU aims to get $20 \%$ of its energy from renewable sources by 2020 . One of the most important parts of renewable energy sources for the majority of middle and north European countries is wind energy. Therefore, the necessity to evaluate economic viability of wind power projects rises. Despite that the state strategy pays much attention to households as producers of green power, researchers focus exclusively on the analysis of large wind plant parks, whereas the economic benefits of household wind power plants are not analysed. Such studies have not been carried out in Lithuania yet. Therefore the aim has been set so draw the IRR distribution map of household wind power projects in Lithuania which might help the households to make decisions regarding the implementation of wind power projects.

\section{Methods and results}

Theoretical discussion embraces the following stages:

1. Investigation of the methods applied in the evaluation of investment projects. Contemporary science of economics offers a great variety of methods to evaluate the efficiency of investment projects. Traditional analysis of discounted cash flows is appropriate to evaluate investment projects in a stable environment. According to Tomaševič V. (2010), investors often demand an easily and quickly countable, objective and universally understandable unit of measure to evaluate investment efficiency. Therefore, it is expedient to use traditional models of discounted cash flow if they are appropriately adopted.

2. Analysis of empirical examination of methods applied practically to evaluate investment projects provided in literature. The article analyses the results of empirical research carried out in different countries. The examination of the empirical research supports the proposal to widely apply traditional investment project evaluation methods in practice.

3. Investigation of methods of wind power project evaluation discussed in scholarly literature. The article analyses investigations targeted at the financial evaluation of wind power projects. The examination revealed that the majority of the authors usually apply two or three methods to evaluate the projects. The methods include net present value (NPV), internal rate of return (IRR) and payback period (Hamouda Y. A., 2012, O’Connor M. et al., 2013).

\footnotetext{
${ }^{31}$ Corresponding author - e-mail address: rasa.kanapickiene@ef.vu.lt
} 


\section{$\left\{\begin{array}{l}\left\{\begin{array}{l}\text { New Challenges of Economic } \\ \text { and Business Development }-2014\end{array}\right.\end{array}\right.$}

May 8 - 10, 2014, Riga, University of Latvia

On the grounds of the theoretical analysis the conclusion is drawn that it is expedient to use traditional evaluation methods to evaluate wind power projects as these projects should be classified as stable environment projects.

The analytical research embraces the following stages:

1. In the research, the evaluation of wind power potential was carried out. The calculation of the potential is based on meteorological annual average wind speed climate normal and average monthly wind speeds in the territory of Lithuania (Lithuanian Hydrometeorological service, 2013). As wind power depends on the wind speed cube $\left(v^{3}\right)$, it is crucial to separately evaluate the power of all wind speeds while calculating total amount of wind energy. For this reason wind speed volatility is generalized by means of Weibull distribution used in quantitative calculation.

2. The amount of electricity power produced in wind power plants is calculated according to the following parameters: a) power curves of small scale plants suitable to use in typical households; b) selection of technical and environmental parameters important for the operation of wind power plants (such as the height at which a wind turbine is installed and ground surface roughness); c) meteorological annual average wind speed climate normal and average monthly wind speeds. Despite that there are simplified construction requirements for the establishment of small scale wind power plants (up to 15 meters heights and $30 \mathrm{~kW}$ ) in Lithuania as well as stable feed-in payments of the electric power is predicted, the number of wind power plants is low. It is due to the lack of both instances of positive experience and extensive financial evaluation of small scale wind power projects. Typical small scale plants were chosen after the analysis of technological premises, natural environment and social-economic conditions was carried out and the criteria for the plant choice were determined.

3. Three projects were chosen for the analysis: the installation of $5 \mathrm{~kW}, 10 \mathrm{~kW}$ and $20 \mathrm{~kW}$ wind turbines. The cash flow generated by the projects under the investigation was calculated. In order to calculate overall energy production cost an extensive analysis of discounted cash flow and energy was used. The main parameters crucial for the calculation were selected, analysed and validated. They include the lifetime of a wind turbine, capital costs of a wind turbine, annual running costs, feed-in payment, increase of running costs, increase of feed-in payment.

4. The map of IRR distribution in Lithuania was drawn and the analysis of the distribution was carried out.

\section{Conclusions}

In the present research, the IRR distribution of projects of small scale wind turbines in households in Lithuania was created. The distribution reveals 1) different IRR of projects for various scale wind turbines established in the same location; 2) the volatility of the IRR of a project for the same scale wind turbine established in different locations which arises due to unequal wind speed in different areas in Lithuania. The spatial distribution of IRR for investment might provide information for investors about favourable locations for the exploitation of wind resources.

\section{Bibliography}

Hamouda, Y. A., 2012. Wind energy in Egypt: Economic feasibility for Cairo. Renewable and Sustainable Energy Reviews, 16, pp. 3312-3319.

Lithuanian Hydrometeorological service, 2013. Climate averages for Lithuania 1981 - 2010. [Online] Available at: http://www.meteo.lt/dokumentai/literatura/Brosiura/Lietuvos_klimatas_09 25.pdf [Accessed 4 February 2014].

O’Connor, M., Lewis, T., Dalton, G., 2013. Operational expenditure costs for wave energy projects and impacts on financial returns. Renewable Energy, 50, pp. 1119-1131.

Tomaševič V., 2010. Evaluation of Investment Projects' Effectiveness by the Net Present Value Method. Business: Theory and Practice, 11(4), pp. 362-369. 


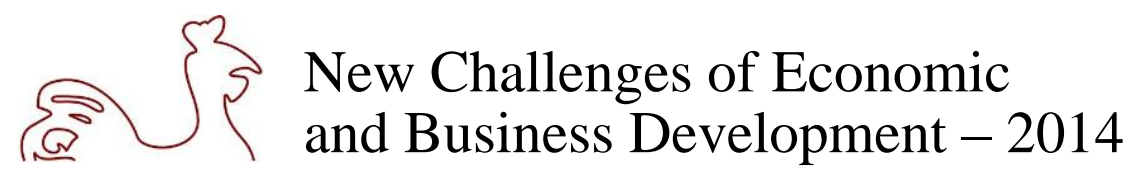

May 8 - 10, 2014, Riga, University of Latvia

\title{
THE INFLUENCE OF TAX EARMARKING ON THE FISCAL POLICY
}

\author{
Lūcija Kavale, University of Latvia, Latvia ${ }^{32}$
}

Key words: fiscal policy; fiscal policy; earmarking of taxes; basic budget; special budget

JEL codes: H02, H03, E06

\section{Introduction}

The changing economy forces the governments to be flexible in taking fiscal decisions and finding new solutions of the state financial governance. One of the topical questions is the financing of the state expenditures in the conditions of scarcity. Practically, all the countries face this situation. In order to take efficient decisions the most investigated methods in the financial science are the expenditure planning methods of the state budget (zero-based budgeting, the budget based on the result, performance budgeting), the choice of which basically determines an effective usage of the funds. The financing of expenditures using the earmarking of taxes is less investigated. In the financial science there are contradictory views and conclusions about the attraction of particular taxes or a part of them to definite expenditures of the state budget. There are different opinions about the advantages and disadvantages of this method and there is also the viewpoint that the earmarking of taxes is rather often applied due to political aims. In general, we must point out that there is a lack of significant theoretical conclusions and assessments which would be the basis for a real action and we must admit that the experience of other countries has not been appropriately estimated.

At present in Latvia the discussions about the earmarking (or not earmarking) of taxes have become topical in connection with the proposal of the government to introduce the obligatory health insurance which is based on shifting (earmarking) the part of personal income tax to the special budget of health care. At the same time there are no discussions about the influence of earmarking on the state basic budget, nothing has been said about the earmarking problems in order to finance particular tasks and there is not a scientifically theoretical substantiation and a critical assessment of the experience in the previous years in Latvia.

The aim of the research: on the basis of theoretical and empirical analysis to find out advantages and disadvantages of tax earmarking and give recommendations for the improvement of the fiscal policy.

The tasks of the research:

1. to investigate, sum up and critically analyse the opinions in the scientific literature about the meaning and pros and cons of the earmarking of taxes;

2. to analyse critically the experience of the earmarking of taxes in Latvia and other countries;

3. to define theoretical guidelines and to make practical recommendations how to use the earmarking of taxes in the state fiscal policy.

\section{Methods and results}

In the research there are used the qualitative research methods: such as the investigation and generalization of the Latvian and foreign literature and scientific publications, content analysis, the research method of special cases, as well as the methods of statistical analysis: such as dynamic row analysis, graphic depiction of data and its analysis.

${ }^{32}$ Corresponding author - e-mail address: luka@lu.lv, phone number: +371 29472792

Lūcija Kavale 
May 8 - 10, 2014, Riga, University of Latvia

\section{Conclusions}

In the conclusions of the research it is pointed out that each country makes its fiscal policy depending on several factors: economic, social and political. The task of the theoretical conclusions is to give an advice to the governments about the consequences of the action and the influence on the society; therefore, theoretical conclusions are important. Solving the financial problems in a particular area (e.g. the financing of health care in Latvia) it is good to know that the earmarking of taxes limits the government's capacity to deal with the money of the budget as a whole which can negatively influence the satisfaction of the common needs of the society.

The research shows that the earmarking of taxes does not create more money for certain activities, on the contrary - in the conditions of crisis there could be problems with accumulating of needed financial resources. 


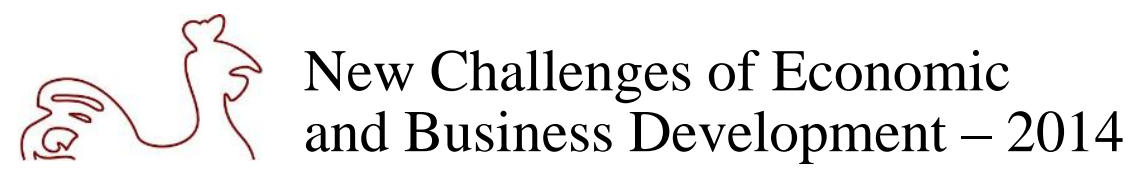

May 8 - 10, 2014, Riga, University of Latvia

\title{
PERSONNEL MOTIVATION FACTOR ANALYSIS
}

\author{
Laura Keršule, University of Latvia, Latvia ${ }^{33}$; \\ Biruta Sloka, University of Latvia, Latvia
}

Key words: personnel motivation, telecommunication, company image, factor analysis

JEL codes: M54, M12, L96

\section{Introduction}

The development of modern telecommunication technologies in the world as well as in Latvia has led to struggle and close contest in today's telecommunication industry. The respective issues have been studied also in recent academic research, it is topical and important to examine the influence of telecommunication reform and efficiency performance: questions are stated - "do good institutions matter?" (Mohamad, 2014). Telecommunication companies around Europe organise cooperation for innovation (Yami and Nemeth, 2013). Multiple case studies in the telecommunication industry on different approaches for more effective management are studied (Battisella, 2013). As telecommunication industry develops very rapidly, companies management are interested to keep professional and loyal employees from one side but from other side need to take into account also limitations of material support for employees therefore many aspects of more efficient personnel management in telecommunications are studied in many countries around the globe (Bogaert and Vloeberghs, 2005). Problems of institutional changes, firm size and wages in telecommunication sector are on research agenda (Majumdar, 2010). Telecommunication companies demand that their staff would be educated, creative, efficient, motivated and loyal. Preparation of good practitioners who are able to perform activities for creation of competitive products and services takes time and huge efforts. Companies are interested to keep their professional staff for the company development even if it is the downturn of economy. For keeping qualified personnel efficient motivation ways and means are needed. Big company management has very special challenges: to keep good and motivated staff, keep company image in the eyes of the customers, current and future employees as well as general public.

The purpose of the paper is to explore relationships between motivation factors and company image attractiveness of company as employer; examine factors that are associated with likelihood that employees will engage in effective and efficient business performance. Comparisons on factors associated with likelihood that employees will engage in effective and efficient business performance are made relationships among - motivation and company image in telecommunication and other industries in Latvia are analysed.

\section{Methods and results}

Research methods used: scientific literature review, survey of employees (1098 surveys of general public and 473 surveys of telecommunications industry employees are used for empirical data analysis). The following measures were used: 1) list of motivators; 2) list of statements on skills, engagement and resources available in company; 3) perceptual performance; 4) demographic profile of sample (age, gender, occupational type and detailed information on position, education, income and industry). The

${ }^{33}$ Corresponding author - e-mail address: Laura.Kersule@1mt.lv, phone number: +371 67773213 


\section{$\left\{\begin{array}{l}\left\{\begin{array}{l}\text { New Challenges of Economic } \\ \text { and Business Development }-2014\end{array}\right.\end{array}\right.$}

May 8 - 10, 2014, Riga, University of Latvia

respondents were asked to use 7-point scale ranging from 1 - strongly disagree and 7 - strongly agree. For data analysis factor analysis as well as indicators of central tendency or location and indicators of variability and cross-tabulations are used. Factor analysis based on survey data on statements how respondents feel attitude to themselves. For rotation was chosen varimax method. Rotation was performed in 6 iterations with Kaiser Normalization. On the results of factor analysis four complex factors were identified on feelings of employees how do they feel in their working place (from 26 statements) and the following complex factor names were given:

- Work professional aspects factor;

- Pay or emolument factor;

- Work creativity factor;

- Work organisation elasticity factor.

More detailed analysis of all 26 statements were performed. Distribution of responses on different statements evaluated show that evaluations of respondents are very different, it means that employees feel differently related to work creativity factors, but there are rather many respondents for all statements that give the highest evaluations, especially for factor respectable job (possibility to perform significant job) etc. To feel comfortable in work place it is important to have also high ranked not material factors and creativity factors, but also other factors which will be evaluated in next research. The evaluations of male and female results do not differ statistically significant. The evaluations on statements do not differ statistically significant by age groups.

\section{Conclusions}

Work creativity factors have big importance for motivation of employees, they are not more significant as material factors. The results of factor analysis four complex factors are identified on feelings of employees how do they feel in their working place (from 26 statements) and have named them: work professional aspects factor; pay or emolument factor; work creativity factor; work organisation elasticity factor. Many of employees have evaluated with the highest grades, but most of employees feel that the work creativity factors related to them personally were on the lowest values, variability of responses was very big, but there is evidence that many of employees feel comfortable with the work creativity factors: they have respectable job (possibility to perform significant job), possibility to take responsibility, interesting job, high requirements.

\section{Bibliography}

Batisella, C., 2013. The Organisation of Corporate Foresight: A Multiple Case Study in the Telecommunication Industry. Technological Forecasting and Social Change, In Press, Available in Science Direct, 20 pages. [Acessed 10 January, 2014].

Bogaert, S., Vloeberghs, D., 2005. Differentiated and Individualized Personnel Management: Diversity Management in Belgium. Europaen Management Journal, 23(4), pp. 483-393.

Majumdar, S. K., 2010. Institutional Changes, Firm Size and Wages in the Telecommunication Sector. Information Economics and Policy, 22, pp. 201-217.

Mohamad, N., 2014. Telecommunications Reform and Efficiency Performance: Do Good Institutions Matter? Telecommunications Policy, 38, pp. 49-65.

Yami., S., Nemeth, A., 2013. Organizing Cooperation for Innovation: the Case of Wireless Telecommunication Sector in Europe, Industrial Marketing Management, In Press, Available in Science Direct, 20 pages. [Acessed 8 January, 2014]. 


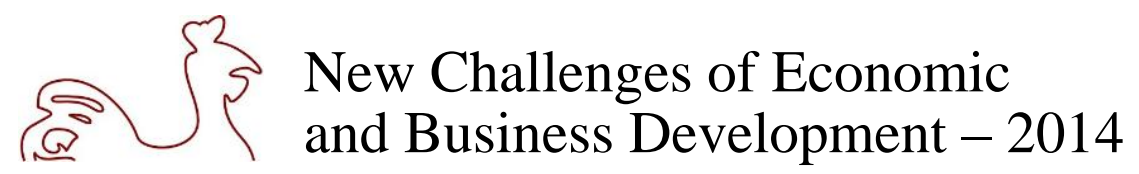

May 8 - 10, 2014, Riga, University of Latvia

\title{
DETERMINANTS OF EARLY-STAGE ENTREPRENEURSHIP IN LATVIA
}

\author{
Marija Krumina, University of Latvia, Latvia ${ }^{34}$
}

Key words: entrepreneurship, early-stage, Global Entrepreneurship Monitor (GEM)

JEL codes: L26, M13

\section{Introduction}

Entrepreneurship is considered to be an important driver for economic growth through employment, productivity improvements and overall welfare effects (Schumpeter, 1934, Acs and Audretsch, 1988, Wennekers un Thurik, 1999, Baumol, 2002, Acs and Storey, 2004). Realizing the importance of the issue, it is crucial to understand what factors stimulate or hinder the willingness to become an entrepreneur and whether these factors change over time.

There are various studies that analyze the determinants of involvement in entrepreneurial activity. Grilo and Thurik (2008) in their study conclude that being a female substantially reduces the probability to be involved in early-stage entrepreneurial activity. Dombrovsky and Ubele (2005) determine that a typical average Latvian entrepreneur is 39 years old ethnic Latvian male. Parker (2011) proves that human capital plays a major role when promoting nascent entrepreneurship. Sanditov and Verspagen's (2011) find that being employed increases the probability to establish the own business. Acs et al (1994) analyzing regional aspect, find that people in the cities are more entrepreneurial than those living in the countryside. Arenius un Minniti (2005) identify, that besides the impact of demographic and economic characteristics, perceptional variables such as alertness to opportunities, fear of failure, and confidence about one's own skills are also very important determinants of one's decision to engage in entrepreneurial activity.

Most of the studies analyze the determinants of entrepreneurial activity at some exact point in time. This paper offers advantage of not only looking at determinants of entrepreneurship but also on changes in determinants over time.

The aim of this paper is to evaluate the impact of various individual, socioeconomic and perceptional variables on the probability of becoming an early-stage entrepreneur in Latvia. Paper also tries to investigate the changes in determinants over time. The research question to be answered in the paper is the following: what are the main determinants of early-stage entrepreneurship in Latvia and how determinants changed over the last nine years?

\section{Methods and results}

Repeated cross-section data of the Global Entrepreneurship Monitor (GEM) ${ }^{35}$ Adult Population Survey's (APS) for the time period from 2005 till 2013 is used for the analysis.

According to GEM definition, an early-stage entrepreneur is an adult individual (18-64 years old) who is either a nascent entrepreneur (i.e. actively involved in setting up the business that (s)he will fully or partially own, but that has not paid wages or other payments to owners for more than three months) or a

\footnotetext{
${ }^{34}$ Corresponding author - e-mail address: marija.krumina@gmail.com, phone number: +37126442811

${ }^{35} \mathrm{GEM}$ is a not-for-profit academic research consortium that produces evaluation of the entrepreneurial activity across the world. GEM's hallmark is its focus on the role played by individuals in entrepreneurship.
} 


\section{$\left\{\begin{array}{l}3 \\ 5\end{array}\right.$ New Challenges of Economic and Business Development - 2014}

May 8 - 10, 2014, Riga, University of Latvia

new business owner-manager (i.e. an adult individual who owns and runs a business that has paid wages to its owners for more than three months but less than 42 months ( 3.5 years).

In order to estimate the influence of the factors, probit regression models are used. The analysis revealed that demographic and individual subjective perceptions of own entrepreneurial skills are the most important determinants of individual involvement in early-stage entrepreneurial activities, while education and employment status being not so important. The main determinants of early-stage entrepreneurship have changed over the last nine years.

\section{Conclusions}

The paper aimed to emphasize the factors that influence the status of early-stage entrepreneurship in Latvia in 2005-2013 time period. Demographic factors (gender and age) and individual perceptions (mostly perception of own entrepreneurial skills) were among the main determinants of becoming an early-stage entrepreneur. The hypothesis of changing importance of the factors that determine involvement in early-stage entrepreneurship during different periods of economic cycle (2005-2013) was also confirmed. Females are not in that big disadvantage against males during boom as compared to other stages of business cycle, while optimism towards one's own entrepreneurial skills is extremely important during recession.

The study of the effects of tax environment, bankruptcy law, social security and other institutional variables as well as expanding research to include more countries are among suggestions for further research.

\section{Bibliography}

Acs Z., and Audretsch, David B., 1988. Innovation in Large and Small Firms: An Empirical Analysis. American Economic Review, American Economic Association, 78(4), pp. 678-90.

Acs, Z., and Storey D., 2004. Introduction: Entrepreneurship and Economic Development. Regional Studies, Taylor \& Francis Journals, 38(8), pp. 871-877.

Acs, Z. J., Audretsch, D. B. and Evans, D. S., 1994. The Determinants of Variations in Self-employment Rates across Countries and over Time, Discussion Paper 871, London: CEPR.

Arenius, P., and Minniti, M. 2005. Perceptual Variables and Nascent Entrepreneurship. Small Business Economics, 24(3), pp. 233-247.

Baumol, W. J., 2002. Entrepreneurship, Innovation and Growth: The David- Symbiosis., Journal of Entrepreneurial Finance and Business Ventures, 7 (2), pp. 1-10.

Dombrovsky, V., \& Ubele, I., 2005, Entrepreneurship in Latvia. Riga: TeliaSonera Institute Discussion Paper (2).

Grilo I. and Thurik R., 2008. Determinants of entrepreneurial engagement levels in Europe and the US, Industrial and Corporate Change, Oxford University Press, 17(6), pp.1113-1145.

Parker, S C., 2011, Intrapreneurship or entrepreneurship?, Journal of Business Venturing, Elsevier, vol. 26(1), pp 19-34

Sanditov, B., \& Verspagen, B., 2011, Multilevel Analysis of the Determinants of Innovative Entrepreneurship across Europe. Maastricht: UNU-MERIT, School of Business and Economics. Paper presented at final DIME Conference 2011.

Schumpeter, J., 1934. The Theory of Economic Development. Cambridge, Mass: Harvard University Press.

Wennekers, A. R. M., and Thurik, A. R., 1999. Linking entrepreneurship and economic growth. Small Business Economics 13, pp. 27-55. 


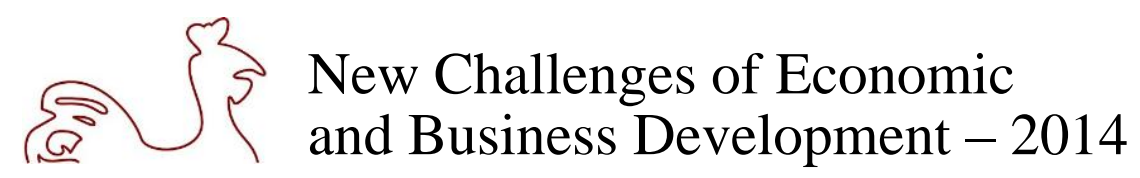

May 8 - 10, 2014, Riga, University of Latvia

\title{
USE OF HOFSTEDE DIMENSIONS IN MULTI-CULTURAL TOURISM PRODUCT QUALITY EVALUATION
}

\author{
Eriks Lingeberzins, Turiba University, Latvia ${ }^{36}$
}

Key words: tourism business product, international tourism, intercultural quality evaluation

JEL codes: L83, M11

\section{Introduction}

The internationalization of the tourism business environment determines need to systematize existing approaches in quality management of tourism business product quality evaluation. Existing literature indicates on complexity of contemporary tourism product definition, emphasizing the importance of each particular service composing tourism business product. At the same time, tourist satisfaction with each separate service received during their trip plays important role in tourism business product quality evaluation which is also directly related to post-tour feedback and customer opinion about the service and product provider in general. In this perspective, comprehensive and deepened understanding of cultural factors and differences influencing tourism product quality evaluation are missed. Further development of the international tourism flow and the emergence of new tourism markets and destinations create new challenges and opportunities for tourism organization, meeting increasing demands of a contemporary, well-educated and often experienced, traveller. Cultural diversity of international travellers is no longer a novelty, even international tourism entrepreneurs do not always meet requirements, set by these travellers. In spite of globalization of the international tourism business environment, cultural differences, grounded in national cultures, defining behaviour of societies in general and their members, still play remarkable role in tourism business product quality evaluation. Understanding of these differences may provide unique opportunities to improve guest satisfaction which, through the development of user-created social media, plays higher importance than ever before. Different approaches to explain and analyse the importance of cultural differences have been used over past decades, however Hofstede culture dimensions model has been proven to be the most universal and stable. It provides overall and comprehensive, well tested system in structuring cultural differences which is its main advantage. Although cultures themselves are not static and are obeyed towards the effects of globalization, such as migration, uncertainty of the uniqueness and the mix of diversity, dimensions, as proposed and developed by Hofstede, are often used to explain divers business management related processes. These dimensions have demonstrated overall stability since the period the concept was developed, allowing to consider the system as stable and available for further research.

The aim of the research is to analyse quality evaluation of a tourism business product, consumed by tourists originating from different countries, representing different cultural backgrounds, using Hofstede cultural dimensions model. They aim to highlight the high importance of cultural differences in service and tourism business product quality evaluation. Results of the research demonstrate the presence and the importance of cultural differences in tourism business product quality evaluation, confirmed by correlation analysis, allowing drawing further recommendations for tourism entrepreneurs. In order to achieve the aim, quantitative research has been performed.

\section{Methods and results}

Tourists from 12 different European and Overseas countries have been questioned using structured questionnaire according to 11 service quality evaluation (5 point Likert scale has been used) in 6 different

\footnotetext{
${ }^{36}$ Corresponding author - e-mail address: Eriks.Lingeberzins@ @inbox.lv, phone number: +371 29172752
}

Eriks Lingeberzins 


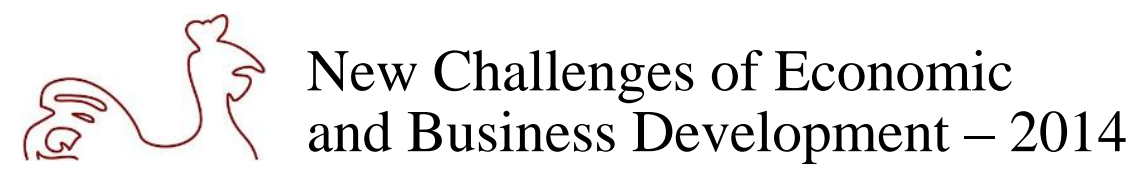

May 8 - 10, 2014, Riga, University of Latvia

destinations in The Baltic Sea region over two consecutive tourism summer seasons (period MaySeptember). Totally 1330 valid questionnaires have been received and used in the data analysis. Core services of a tourism business product have been included (accommodation, transportation, guide service) with sub-categories (such as evaluation of food, room and location for hotels, knowledge and language skills for guide service, etc). All answers have been assigned with evaluation between 1 (unacceptable) and 5 (excellent) and average value calculated. All 12 countries have been represented by a sample of $\mathrm{n} \geq 30$. Data analysis has been performed using correlation analysis with average values of 11 services tourists had assessed and five (LTO, PDI, IDV, MAS, UAI) Hofstede dimensions scores, defined by previous research of Hofstede. Spearman's-Kendall's correlation coefficients have been calculated using SPSS 17.0 system. Only those coefficients where $r \geq \pm 0.40$ ) justifying at least moderate relationship. Selected methods allow identifying the presence of systematic relation between included samples as research include data obtained from service evaluation of the same tourists in 6 different destinations (Vilnius, Riga, Tallinn, Helsinki, St. Petersburg, Moscow).

Data interpretation has been done to identify presence of provided service quality evaluation coherence with Hofstede culture dimensions model in order to determine its utilization in formulating applied recommendations for tourism business organizations. Firstly, author observed the presence of different relation between research samples which can be considered as sufficiently strong and obvious to draw conclusions about the importance of culture in service product and tourism business product quality evaluation. Secondly, obtained observations indicate on the presence of equivocal results, emphasizing needs to diversify research methods and use alternative approaches to justify achieved results. Based on achieved date, it can be concluded that not all five Hofstede dimensions provide opportunity to draw conclusions justifying the existence of strong relation between the dimensions of culture and the average values of the provided service quality evaluations.

\section{Conclusions}

Author concludes that research results provide unique understanding of the importance of cultural differences in service quality evaluation and the selected model indicates on certain relation between the cultural dimensions and the service quality evaluation approach by tourists, origination from different European and Overseas destinations. These results confirm existing assumption about the importance of cultural differences in service quality evaluation, allowing develops system of service quality management and improvement. Author's assumptions are confirmed by identified from moderately strong to strong positive and negative relation between the Hofstede dimensions and service quality evaluation of a multidestination tourism business product. At the same time, author concludes that use of alternative approach and in particular cluster analysis of the samples may provide alternative view points of the subject.

\section{Bibliography}

Basabe, N. \& Ros, M., 2005. Cultural dimensions and social behavior correlates: IndividualismCollectivism and Power Distance. Revue Internationale De Psychologie Sociale, No. 1, 2005.

De Mooji, M. \& Hofstede, G., 2010. The Hofstede model - Applications to global branding and advertising strategy and research. International Journal of Advertising. Vol. 29(1), pp. 85-110.

Hofstede, G., 1989. Organizing for cultural diversity. European Management Journal. 19 (4), pp. 390.-397.

Hoppe, M.H., 2004. Introduction: Geert Hofstede's Culture's Consequences: International Differences in Work-Related Values. Academy of Management Executive. Vol. 18, No.1, 73.-74.

Litvin, S.W., Crotts, J.C. \& Hefner, F.L., 2004. Cross-cultural Tourist Behavior: a Replication and Extension Involving Hofstede's Uncertainty Avoidance Dimension. International Journal of Tourism Research. Vol. 6, pp. 29.-37. 


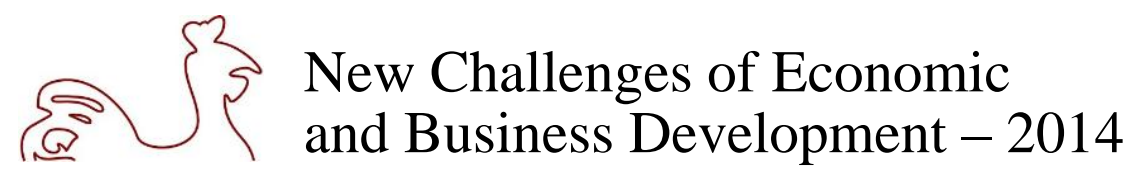

May 8 - 10, 2014, Riga, University of Latvia

\title{
ECONOMIC GROWTH IN FIRM INVESTMENT POLICY MODEL ACCOUNTING FOR EMPLOYEES LEARNING
}

\author{
Maria Makarova, Moscow Institute of Physics and Technology, Russian Federation ${ }^{37}$
}

Key words: Vintage Capital, Investment Policy, Optimal Control, Production Function

JEL codes: C61, C68, O40

\section{Introduction}

A modification of the model, developed in (N.N. Olenev, I.G. Pospelov, 1986), is proposed. The economy consists of a pool of small firms. The firm is interpreted as an aggregate of all production lines, created at the same moment. While the original model assumes that the production capacity of a firm decreases in time, in (Makarova, Olenev, 2013) a model with the production capacity increasing with employees learning is specified. The learning of the firm management is modelled with the dependancy of the production capacity on time, and the learning of the staff is modelled with the functional relation between capacity and the cumulative production of the firm. Taking into account employees learning allows to model economy of innovative firms more accurately.

The purpose of the research is to specify the investment and production policy of a single firm and to apply the results to a macroeconomic model. The regimes of the models were studied theoretically and numerically, and the comparison of models with and without employees learning was performed.

\section{Methods and results}

We consider an economy producing single product and using single resource - labour. The main assumption is that capacity of a firm depends on the time non-monotonically (increasing in short-term and decreasing in long-term), and it also increases with an increase in cumulative production of the firm since its start, while the number of employees is constant. A firm solves an optimal control problem that maximising the profit, given constant product price and labor costs. The solution of the optimal control problem is starting the production using full capacity at the moment $t_{0}$, which can be equal or non equal to zero depending on the parameters.

A dynamic macroeconomics model has been built. The agents are firms, that take decisions whether to start (or continue) production at each moment of time. They take into account product price $p$ (defined by market equilibrium) and labour costs $s$ (defined by deficiency or surplus of human resources). In case production is profitable under current prices, new firms are founded. The availability of funds is restricted by credit capacity of the financial system.

One of the most important regimes is exponential growth regime in which price and labour cost remain constant, and investment, production and number of employees grow exponentially with rate $\gamma$. The Solow's golden rule (for example, (Abel A.B. et. al., 2005)) for the system described in this article is the following:

$$
f(x, \gamma)=x s / p+\beta
$$

Where $x$ is ratio between number of employed and investments, $f$ - ratio between production and investment and $\beta$-capital intensity of new production capacity.

${ }^{37}$ Corresponding author - e-mail address: Makarova.mar@ gmail.com, phone number: +442 035837879 


\section{$\left\{\begin{array}{l}3 \\ 5\end{array}\right.$ New Challenges of Economic and Business Development - 2014}

May 8 - 10, 2014, Riga, University of Latvia

Though the equations for the financial system do not form part of Solow's golden rule proof, numerical experiments show, that parameters $f, x, \gamma$ set in the system, satisfy Solow's equation. The dependency between parameter, controlling the importance of employees learning and macroeconomics growth rates has a maximum, which indicates that there is an optimal degree of learning importance providing the fastest growth (Figure 1).

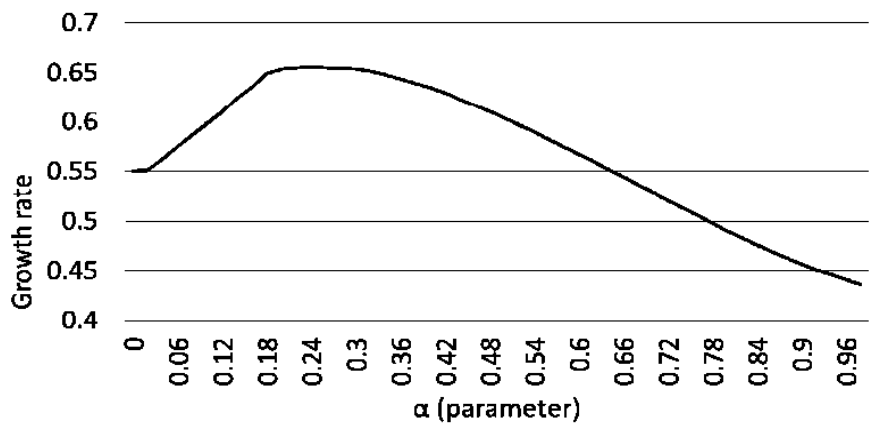

Source: author's construction based on numerical experiments with the model.

Fig. 1. Growth rates for different importance of employees learning (controlled with the parameter $\alpha$ )

The duality of production and profit functions has been proven theoretically (similarly to Shananin, 1984).

\section{Conclusions}

A new economics model was build accounting for increasing of production capacity of the firm in time, which has been proved to result in a lag between investment and production. This lag is typical for technological industries, like IT and pharmaceutics. The model is relevant for the analysis of the consequences of economic decisions, especially during the crisis.

One of the important numerical results is that equilibrium growth parameters satisfy Solow's equation. It was also concluded that the dependency between the degree of importance of employees learning and the growth rate has a maximum. This result indicates the level of human capital intensity, optimal for economic growth, which can be used for development of economic policy. Further research is suggested on the influence of government measures and subsidising on the investment policy of innovative firms and economic development.

The work was partly supported by RFBR grants 13-07-01020, 12-01-00916.

\section{Bibliography}

Abel, Andrew B.; Bernanke Ben S., Smith Gregor W. \& Kneebon , Ronald D., 2005. Macroeconomics. Toronto: Pearson Education Canada.

Makarova Maria, Olenev Nicholas, 2013. On Firm Investment Policy Accounting For Employees Learning. // IV International Conference on Optimization Methods and Applications "Optimization and applications" (OPTIMA-2013). Petrovac, Montenegro, September 22-28, 2013. Abstracts, pp. 109-110.

Olenev N.N., Pospelov I.G. The Model of Investment Policy in Market Economy. Mathematical Modelling: Processes in Complex Economic and Ecologic Systems Moscow: Nauka, 1986, pp. 163-173. (in Russian)

Shananin A. A., 1984. Investigation of a class of production functions arising in a macrodescription of economic systems. , Zh. Vychisl. Mat. Mat. Fiz., 24:12 1799-1811. In Russian. 


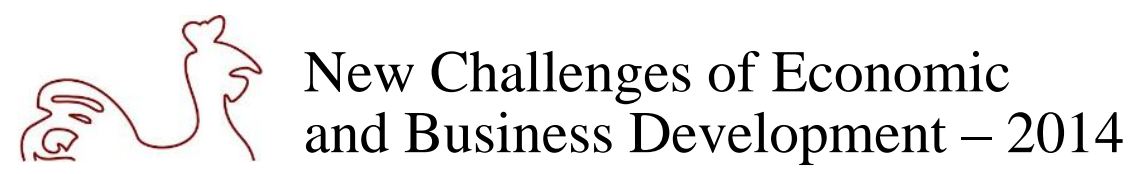

May 8 - 10, 2014, Riga, University of Latvia

\title{
POSSIBILITIES TO APPLY BANKRUPTCY PREDICTION MODELS IN LITHUANIAN COMPANIES OF CONSTRUCTION AND TRANSPORT
}

\author{
Rosvydas Marcinkevičius, Vilnius University, Lithuania; \\ Rasa Kanapickienė, Vilnius University, Lithuania ${ }^{38}$
}

Key words: bankruptcy, bankruptcy prediction, bankruptcy prediction models

JEL code: G33

\section{Extended abstract}

The article presents the results of the research in the application of bankruptcy prediction models in the sectors of construction and transport in Lithuania.

\section{Introduction}

Constantly changing business environment makes it difficult to maintain stable activity of a business. In order to identify the reasons of the deterioration of the company's financial state and factors which determine the financial decline of companies as early as possible, the executives must constantly carry out bankruptcy prediction.

The object of the research is bankruptcy prediction of companies. The aim of the research is to investigate and evaluate the possibilities to apply bankruptcy prediction models in Lithuanian companies in construction and transport sectors. The formulation of the aim is drawn on the fact that a mainly transport and construction company has gone bankrupt since the world crisis till now.

\section{Methods and results}

The research of the application of bankruptcy forecasting models in Lithuania. Lithuanian scholars have contradictory opinions about the possibilities to apply bankruptcy prediction models. Many of the scholars who have investigated various models of bankruptcy prediction have not come up to an agreement as to the suitability of bankruptcy prediction models for Lithuanian companies. Nonetheless, they emphasized that the academic research in the field must be continued. Empirical researches provide conflicting results as well.

Lithuanian scholars (Mackevičius J. \& Rakštelienė A., 2005, Tvaronavičienė M., 2001, Mackevičius J. \& Silvanavičiūtė S., 2006, Garškaitė K., 2008) have mostly applied the model of Altman to examine and apply bankruptcy prediction models. So Lithuanian scholars (Mackevičius J. \& Silvanavičiūtė S., 2006, Garškaitė K., 2008, Kanapickienė R. et al., 2008) examined the application of other classical statistical models: Altman (dedicated to evaluate companies whose shares are quoted in stock exchange), Springate, Taffler \& Tisshaw, Zavgren and Chesser, Liso, Grigavičius, Stundžienè \& Boguslauskas. Karalevičienė J. \& Bužinskienė R. (2012) investigated modern models of bankruptcy prediction.

It should be noted that earlier researches tackled small numbers of companies which could have determined a rather great inaccuracy of the results. There is also a lack of research on the specifics of bankruptcy models' application in different sectors of economic activity.

\footnotetext{
${ }^{38}$ Corresponding author - e-mail address: rasa.kanapickiene@ef.vu.lt
} 


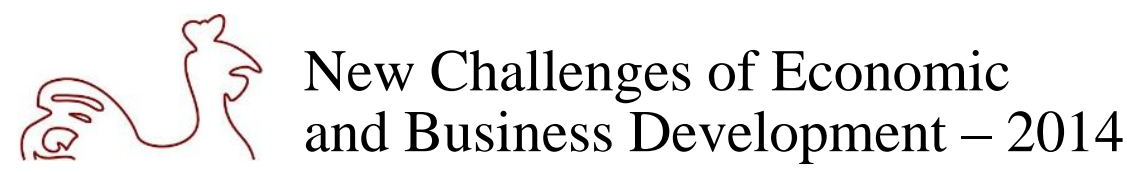

May 8 - 10, 2014, Riga, University of Latvia

The above mentioned reasons encourage evaluating the accuracy of bankruptcy prediction models by considering large numbers of companies as well as attesting real benefits of the acquired information.

Methodology of the survey to evaluate the applicability of bankruptcy prediction models in the transport and construction sectors. After the evaluation of the tendencies of bankruptcy development in Lithuania and with regard to the statistics of the bankrupt companies, companies form the construction and transport sectors were selected for the present survey.

In order to evaluate the accuracy of bankruptcy prediction models and ensure the quality of the acquired data, empirical calculation of 736 companies whose bankruptcy processes were initiated in 2009-2013 was carried out. These include 521 construction companies and 215 transport companies. In this way the following results were acquired: $95 \%$ probability and $3.5 \%$ error in the construction sector and $95 \%$ probability and $5.8 \%$ error in the transport sector.

Annual financial statements of 2007-2012 of the investigated companies were analysed. Since bankruptcy processes for the investigated companies were initiated in 2009-2013, the financial data of the companies was taken from the period of three years before the bankruptcy initiation. The present study distinguishes by its broad scope that was targeted for the first time.

Explication of the survey results on the applicability of bankruptcy prediction models. To achieve the aim of the research, i.e., to evaluate the applicability of bankruptcy prediction models in Lithuanian companies, 5 classical statistical bankruptcy prediction models were chosen: 3 linear discriminant analytical models (Altman, Springate, Taffler \& Tisshaw) and 2 logistic regression models (Chesser, Zavgren).

\section{Conclusions}

Scholarly research in Lithuania gives unanimous prospects of the possibilities to apply bankruptcy prediction models.

After the research has been carried out it is possible to arrive at the conclusion that the most accurate bankruptcy prediction models in the sectors of construction and transport in Lithuania whose bankruptcy probability is the highest are the following ones: the linear discriminant Springate model and the logistic regression Chesser model. The survey proved that the least accurate bankruptcy prediction model is the Taffler \& Tisshaw model.

\section{Bibliography}

Garškaitė, K.,2008. Application of Models for Forecasting of Enterprise Bankruptcy. Business: Theory and Practice, 9(4), pp. 281-294.

Kanapickienė, R., Rudžionienė, K., Griauslytė, R., 2008. Forecasting Company Bankruptcy: Lithuanian Case. Business analysis, accounting, taxes and auditing, pp. 52-56.

Karalevičienė, J., Bužinskienė, R., 2012. The Suitability Evaluation of Modern Bankruptcy Models for Enterprises Bankruptcy Diagnosis. Journal of Management, 1(20), pp. 45-54.

Mackevičius, J., Rakštelienè, A., 2005. Employing Altman's Models to Predict Bankruptcy of Lithuanian Companies. Monetary Studies, 1, pp. 24-42.

Mackevičius, J.; Silvanavičiūte, S., 2006. Evaluation of Suitability of Bankruptcy Prediction Models. Business: Theory and Practice, 7(4), pp. 193-202.

Tvaronavičienè, M., 2001. Approaches to Enhancing of Efficiency of Enterprises' Bankruptcy Process. Economics, 54, pp. 135-143. 


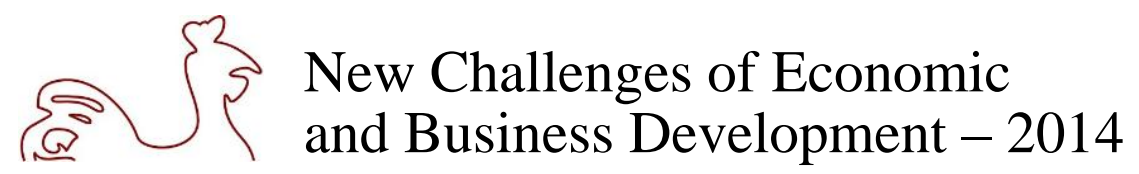

May 8 - 10, 2014, Riga, University of Latvia

\title{
MARKET-ORIENTED EXTERNAL HUMAN RESOURCE MARKETING IN GERMANY - OVERVIEW OF EXISTING EXPERIENCE AND ACTUAL SITUATION IN GERMANY
}

\author{
Susanna Minder, University of Latvia, Latvia ${ }^{39}$ \\ Key words: external human resource marketing, market-orientation \\ JEL codes: J23, J24, M51

\section{Introduction} \\ A market-oriented approach to external human resource marketing is crucial for all organizations. The \\ urgency for focusing on the labor market demands becomes more and more a critical endeavor for \\ companies. Crucial for that requirement is to demonstrate (potential) employees a relevant, strong and \\ individual image of the offered employer's performance and the expected organization's demands on the \\ employee. This results in congruence of employee and employer. The paper gives an overview of the \\ existing experience concerning external human resource marketing and the company internal premises it \\ is based upon. In a second step the situation on the German labor market is exemplarily described. Hereby \\ statistical data is shown to explain the actual situation in Germany.
}

\section{Methods and Results}

Human resource marketing is defined as a cross-divisional process within the realm of human resource management. The promotion and competitive position of an organization on the labor market is achieved by employer branding and an adequate employee search. Therefore a suitable mix of different instruments needs to be available to the company. Hereby the aim of external human resource marketing is to positively position the organization on the labor market and establish an environment that attracts potential employees (Schlabinger \& Hansen, 2004, p. 62f.). An overview concerning employer branding and employee search is given in the paper. These two aspects illustrate how the design of a marketoriented approach of external human resource marketing is conducted. Crucial is hereby how organizations can position themselves on the labor market to attract their target group. This means especially the ability to show actual and potential employees a relevant, strong and unique image of the employer. Following the overview of employer branding measurements is an overview of the aspect of employee search. Hereby the focus lies on how to approach potential employees on the labor market and how to gain them to apply at the company. For both aspects a literature review is used and information is drawn form that research method.

On the other hand external human resource marketing is based on company internal information which is the foundation for the conceptualization of the whole human resource marketing process within a company. Also hereby a literature review is used to give an overview of state of the art procedures in organizations. Another important factor concerning the market-oriented conceptualization of external human resource marketing is the labor market itself. Labor demand and supply are the driving forces for the establishment of human resource marketing. The exchange conditions vary from country to country. In the paper the main exchange factors which are found on the German labor market are exemplarily

${ }^{39}$ Corresponding author - e-mail address: info_minder@gmx.de, phone number: +49 1788601284

Susanna Minder 


\section{$\{3$ New Challenges of Economic and Business Development - 2014}

May 8 - 10, 2014, Riga, University of Latvia

explained with selected statistical data. They lay the ground for the future relevance of human resource marketing in Germany.

\section{Conclusions}

German companies are confronted with an increasing change on the labor market. Their survival is dependent on their flexible and fast reaction to this new situation. A driving factor of the organization's handling of change is its employees and the quality of that intangible resource. Hereby the quality of the company's human resources is getting more and more important compared to other resources, know-how, location and costs. (Simon \& al., 1995, p. 9f.)

A limiting factor hereby is the development on the German labor market. Human resources are becoming more and more a bottleneck. This situation will get worse as the workforce on the German labor market will decrease. The labor demand on the German labor market exceeds the labor supply (Klinger, Bonin, Horn, \& Raffelhüschen, 2013, p. 148ff.). With the reduction of labor force and the increased demand for human resources within companies, the competition between different organizations for employees will get tougher. Organizations have established external human resource marketing instruments to position themselves on the labor market. Employer branding and its measures is getting more and more important for companies. The market-oriented approach of human resources is an indicator for the quality of this process with an organization. Besides, endeavors have been taken into account to attract (potential) employees to companies. External human resource marketing is getting more and more a crucial process within organizations to meet the requirement of the labor market. Companies have taken efforts to establish instruments and measures as a suitable marketing mix, for promotion and the reach of a competitive position of an organization on the labor market.

\section{Bibliography}

Klinger, S., Bonin, H., Horn, G., \& Raffelhüschen, B., March 2013. Erwerbstätigkeit auf Rekordniveau Ergebnis richtiger Arbeitsmarktpolitik? (L. Informationszentrum, Ed.) Wirtschaftsdienst - Zeitung für Wirtschaftspolitik, Vol. 93 (3), pp. 143-158.

Schlabinger, G., \& Hansen, S., 2004. Personalmarketing im klinischen Bereich. In W. Fröhlich (Ed.), Nachhaltiges Personalmarketing. Strategische Ansätze und Erfolgskonzepte aus der Praxis, pp. 61-78. Frechen: Ritterbach.

Simon, H., \& al., e., 1995. Effektives Personalmarketing. Strategien, Instrumente, Fallstudien. Wiesbaden. 


\title{
$\left\{\begin{array}{l}3 \\ 5\end{array}\right.$ New Challenges of Economic and Business Development - 2014
}

May 8 - 10, 2014, Riga, University of Latvia

\section{EXPLORING THE CONCEPT OF CULTURAL AND CREATIVE INDUSTRIES}

\author{
Ieva Moore, University of Latvia, Latvia ${ }^{40}$
}

Key words: creative industries; cultural industries, cultural economics; innovation; cultural statistics, social networks

JEL codes: Z1, O14

\section{Introduction}

Innovation in the 21 st century is still the main driver of economic growth, however the concept has shifted from being primarily technological innovation as emphasized by the EU Lisbon Strategy's 'information society' mantra, to a broader understanding of innovation including non-technological changes and intellectual capital, which is more suitable for a service-based sustainable society. In policy documents the creative and cultural economy is referred as an important part of the global economy, because of the socio-economic potential of activities of creativity, knowledge and information, a generator of jobs, wealth and cultural engagement. According to a UNDP report, Cultural and Creative Industries (CCI) contribute up to $7 \%$ of GDP, the highest being in the US, exceeding 7\%, and in Europe the UK is the highest, exceeding $6 \%$, and is the fastest growing sector of those economies.

The term Creative Industries (CI) has been used in Latvia since 2005, similarly in other Baltic States. Latvia as many others has accepted the CI definition provided by the British Department of Culture, Media and Sports. The term "cultural and creative industries" is known to Latvian cultural policy makers, but in broader entrepreneurship policies it is used very little. In spite of the lack of attention by economic policy makers, CI exist in Latvia, therefore it warrants discussion about them and analysis of their economic condition as a means of understanding more deliberately their economic potential.

This research paper has three main themes - (a) key descriptions of CCI and related concepts; (b) statistical perceptions and the limitations of existing statistical frameworks; and (c) some interesting theories of how to perceive CCI.

\section{Methods and results}

The aim of this paper is to explore the concept of CCI via literature review and to identify the most important terms and theories. This research is crucial because many literature sources express policy formulations which could be questioned with respect to their academic strength.

The concept of CCI is relatively new and the past decade shows that it is evolving, which implies that there is room for further exploration of how to apply this often inspiring concept. New technologies inspire culture changes, thereby linking culture to innovation. In the CCI culture and creativity become important input factors because of content creation and new activity models.

The CCI industries were invented in the 1990s by British politicians, but cultural industries exist from the 1940s in the context of industrialization from the 18th century and the formation of industrial society.

This paper touches the Creative Economy concept, illustrating the popularity of creativity as an asset, based on the principle of intellectual property and digital technology for economic growth.

The 'core' CI puts arts, creative talent and skills at the center of the creative economy and thus cultural industries become part of the "real" economy where durable, "useful" goods are manufactured. The demand

${ }^{40}$ Corresponding author - e-mail address: moore@latnet.lv

Ieva Moore 


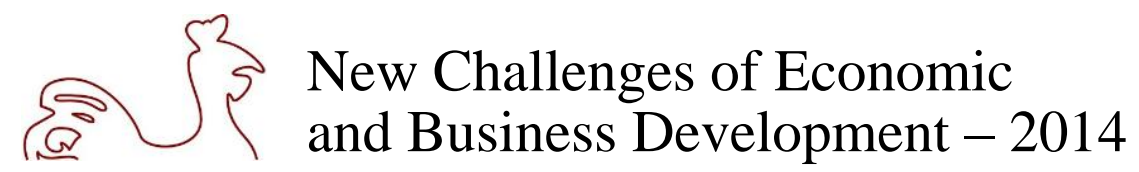

May 8 - 10, 2014, Riga, University of Latvia

for cultural production lies with popular culture and mass culture. For the US “... economically, popular culture has become the nation's leading export". (LeRoy A. 2010)

The second theme of this paper highlights the search for a uniform definition and to provide a taxonomy and data which can be interpreted in a synchronized way, but digitalization is certainly a challenge. Despite the clear presence of the CCI concept, most European governments did not adopt the British formulation. Key policy decisions on CCI are increasingly carried out at an international level.

The third part of the paper looks at theories within the CCI discourse. Problems of a unified classification of CCI have led to authors exploring a broader understanding, for example the Four Models theory of CCI, (Cunningham 2008) suggesting that it would not be correct to perceive CCI as just another sector of the economy, with implications on social welfare, competitiveness, growth and innovation, because of different policies - a welfare subsidy, industrial policy; and investment or innovation policy. Similarly the Social Network Markets theory broadens the understanding of the CCI (Potts et al 2007).

\section{Conclusions}

The concept of CI in an international context emerged primarily as a policy discourse, therefore it is important to distinguish an academic approach from policy papers. CCI represent a variety of industries, from the highly capital-intensive to the more labor-intensive and artisanal, through to highly commercial sectors. The "pure" arts sectors are enabled largely by public subsidy.

Cultural industries exist for several decades, however ICT has changed the ecosystem, where CI are the 'core' of the "concentric circles" approach. In non-standard modes of production value creation is linked to social networks, where values of acceptance and appreciation are created by the network itself.

The literature disagrees about CCI, where software, games and electronic publishing inflates measures of CCI and typically excludes heritage, tourism, entertainment and sport. Over time the CCI dispute is likely to be solved by international organizations, such as the EC (EUROSTAT). Also there are shortcomings of NACE and SBS classifications to capture culture-based businesses. To reflect reality nomenclatures require the adoption of a richer taxonomy of cultural sub-categories.

The theory of the four models of CCI gives a broader understanding of their impact on society, which is not only the production of goods and services, but also their influence as culture processes of innovation, competitiveness and social wellness as key elements of social capital.

Since the current industry classifications of CCI are not a good fit with the traditional supply-demand dynamics of commodities, capital and markets, describing CCI with social markets theory is worthy of further research.

\section{Bibliography}

UNCTAD; UNITED NATIONS, 2008. Creative Economy Report, The Challenge of Assessing the Creative Economy: towards Informed Policy-making, United Nations. [Online] Available at: http://www.unctad.org/en/docs/ditc20082cer_en.pdf.

ESSnet for Culture Report, 2012. [Online] Available at: http://ec.europa.eu/culture/our-policydevelopment/documents/ess-net-report-oct2012.pdf.

LeRoy A., 2010. Not Necessarily Swill time: Pop. Culture and American History. OAH Magazine of History, Vol. 24 (2).

Cunningham, S. \& Potts, J., 2008. 4 models of the creative industries; Intern. J, of Cultural Policy, 14(3).

Potts, J., Ormerod, P., Cunningham, S., Hartley, J., 2007. Social network markets: A new definition of the creative industries, CCI working paper, QUT. 


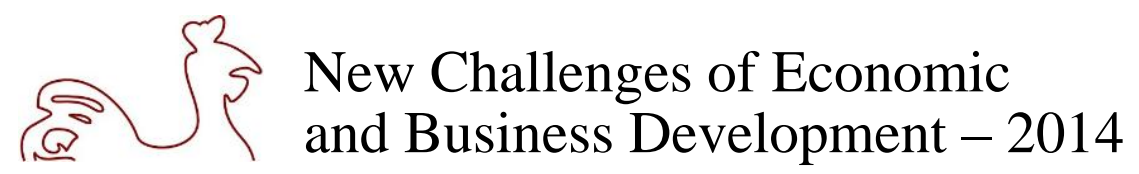

May 8 - 10, 2014, Riga, University of Latvia

\title{
NIMBY EFFECT IN ENVIRONMENTAL IMPACT ASSESSMENT
}

\author{
Leila Neimane, University of Latvia, Latvia ${ }^{41}$ \\ Key words: NIMBY effect, environmental impact assessment, strategic environmental assessment, public \\ participation
}

JEL codes: K32, O13

\section{Extended abstract}

Environmental impact assessment is a legal notion. According to paragraph 1 of article 1 of law "On Environmental Impact Assessment", it is defined as a procedure in order to estimate the potential impact on the environment of the project or the planning document and to work out the proposals for removal or reduction of adverse impacts or to prohibit the launch of the proposed activity in case of infraction of regulatory requirements of law.

The environmental impact assessment is tightly connected with the concept of sustainable development since at the centre of each is the idea that environmental considerations must animate and inform public policy (Craik N., 2008). It results in the need to reconcile environmental, social and economic interests and has become one of main challenges for the developers of projects nowadays. They are faced with public opposition towards the implementation of the projects in local communities, often characterised with NIMBY (Not-in-My-Backyard) effect (Wilkinson D., 2002). There are existing phenomena that certain services are in principle considered as beneficial by the public in general, but specific projects that are needed to implement for provision of these services are often objected by local inhabitants (Van der Horst D., 2007).

In the specialized literature there are distinguished two types of NIMBY effect - the traditional NIMBY (proximity-hypothesis) and inverse NIMBY (contestation of proximity-hypothesis) (Van der Horst D., 2007; Musall D. F \& Kuik O., 2011). Still the concept of NIMBY effect does not reflect all range of public considerations which might be grounded not only on selfish reasons, but on the disagreement of used technologies, the concerns of aesthetic value, social, political, and historical context, the results of the discussion process and the particularities of the construction project (Wolsink M., 2007; Haggett C., 2011). The reasons of public opposition towards implementation of the project must be dealt in a more complex manner than only generalising them under the NIMBY concept. It is quite possible that the implementation of the project is stopped not due to its geographic location, but rather due to ideological considerations.

\section{Introduction}

Considering unambiguous use of notion NIMBY effect, it must be taken into account that public opposition towards the implementation of projects is not always on the grounds "selfish". A correct understanding of the reasons of public opposition would help to resolve the conflict between stakeholders. It is sorely important, as this conflict might stop the implementation of the project.

The legal framework of Latvia sets the procedural rules of tools for the identification of public opinion in a vast manner, although such approach might undermine the meaning of public participation and complicate the implementation of the project for a developer later. The research aim is prima facie

\footnotetext{
${ }^{41}$ Corresponding author - e-mail address: leila.neimane@eia.lv, phone number: +371 29321811
} 


\section{$\left\{\begin{array}{l}3 \\ 5\end{array}\right.$ New Challenges of Economic and Business Development - 2014}

May 8 - 10, 2014, Riga, University of Latvia

existing NIMBY effect to interrelate with legal implications and to work out the suggestions for the improvement of the legal framework in Latvia.

\section{Methods and results}

This research is based on the analysis of legal norms, legal doctrine, specialized literature and case studies. There are used traditional legal research methods.

A description of legal phenomena, law institutes and social phenomena of NIMBY effect is presented in the research in a general way (the monographic technique) and by essence (the dogmatic and the special analytical techniques). The disclosure of essence and meaning is a necessary part of the process to depict the content of substantive and procedural rights in the environmental impact assessment and their interrelation with NIMBY concept. Furthermore, there is applied the sociological method - on the one hand, reflecting the interaction of the transformation of the content of legal norms and their application and, on the other hand, the changing societal needs and requirements. There are used two local case studies to exemplify the behaviour of society.

Finally, the results of the research are presented as the general conclusions, consolidated by synthesis approach and deductive method.

\section{Conclusions}

The research concludes that the notion of NIMBY effect largely used in the specialized literature envisages possible conflict between society and the developer. Rather to classify every public opposition as NIMBY, there is a need to identify the grounds of public position and to group them in categories. Each category of reasons must be dealt accordingly. One of the methods in order to identify the grounds of public opposition might be the interpretation of the results of the public survey. These results might be used for the resolution of the conflict between stakeholders in a particular project. Moreover, large data accumulated over a period might be gathered, grouped by project kinds and categories of reasons. Later on such data might be used during the preparation of future environmental impact statements, specifically analysing the issues concerned in surveys. In the legal framework, the obligation to conduct a public survey must be the duty of the developer and not a question of choice.

\section{Bibliography}

Craik, N., 2008. The International Law of Environmental Impact Assessment. New York: Cambridge University Press.

Haggett, C., 2011. Understanding public responses to offshore wind power. Energy Policy, 39, pp. 503-510.

Musall, D. F \& Kuik, O., 2011. Local acceptance of renewable energy - A case study from southwest Germany. Energy Policy, 39, pp. 3252-3260.

Par ietekmes uz vidi novērtējumu: LR likums. 1998. gada 14. oktobris. [Law of the Republic of Latvia of 14 October 1998 "On Environmental Impact Assessment”]. [Online] Available at: http://www.likumi.lv [Accessed 20 February 2014].

Van der Horst, D., 2007. NIMBY or not? Exploring the relevance of location and the politics of voiced opinions in renewable energy siting controversies. Energy Policy, 35, pp. 2705-2714.

Wilkinson, D., 2002. Environment and Law. London: Routledge.

Wolsink, M., 2007. Wind power implementation: The nature of public attitudes: Equity and fairness instead of 'backyard motives'. Renewable and Sustainable Energy Reviews, 11, pp. 1188-1207. 


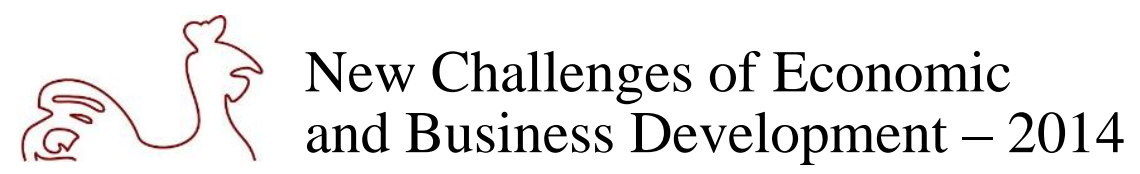

May 8 - 10, 2014, Riga, University of Latvia

\title{
E-ANNUAL REPORTING OF THE ESTONIA TOP100 COMPANIES FOR THE YEARS 2007-2012
}

\author{
Monika Nikitina-Kalamäe, Tallinn University of Technology, Estonia ${ }^{42}$; \\ Natalja Gurvitš, Tallinn University of Technology, Estonia
}

Key words: annual report, e-annual report, e-reporting environment

JEL code: M41

\section{Introduction}

It is well known that the on-time submission of annual reports is highly demanded by various users in different countries. Since the restoration of the independence in Estonia the submission process has undergone three different stages of development. Till 2002 all annual reports were submitted only on paper. In the period 2002-2009 there was added a possibility to submit the annual report electronically in PDF of RTF formats. The companies could choose the most suitable option. As of January 2010, entrepreneurs in Estonia can submit annual reports in XBRL format via the e-reporting environment of the e-Commercial Registry Company Registration Portal. This project was implemented at the national level and was among the largest in 2010 in terms of its scope and volume, by involving more than 120,000 companies. XBRL format is being increasingly recognised as the global standard for transferring business information, which ensures better availability of data. (eRIK). The possibility to submit a paper annual report still existed in 2010, but these reports could not be submitted directly to the Register but only via notary. The e-annual reporting environment, created by the Estonian Centre of Registers and Information Systems for entrepreneurs to enable filing annual reports electronically, was voted the best solution of its category from among more than 460 projects at the global e-solution contest World Summit Award 2011. (Ministry of Justice). The e-government system used in Estonia has created more transparent, efficient, convenient and trustworthy relations between citizens and government agencies. (World Summit Award). According to the Centre of Registers and Information Systems the key principle of submitting data should be that a reporting entity submits the figures required by the state once in the agreed format and in one place and the data thus submitted can be used both by the private and public sectors. Such system of data submitting enables the system of automatic checking to be created that will notify reporting entities of possible errors upon entering the data and would thus support the improvement of the quality of data. In addition, this would help decrease the number of warnings and fines issued every year to reporting entities for their reporting faults. (eRIK) The system is transparent and easy to use.

\section{Methods and results}

Authors made a research on the on-time submission of the e-annual reports for the years 2007-2012 by the most successful TOP100 Estonian companies as stated in the list published by the Estonian business newspaper "Äripäev". The aim of the research was to find out if these companies were also successful in the on-time submission of annual reports and if the on-time submission increased after the implementation of e-annual reporting environment. The authors have used the "Äripäev" newspaper information base, accessed in July-August 2013 and received information about the almost 600 reports of

${ }^{42}$ Corresponding author - e-mail address: monika.nikitina-kalamae@ttu.ee, phone number: +372 6204001 


\section{$\left\{\begin{array}{l}\left\{\begin{array}{l}\text { New Challenges of Economic } \\ \text { and Business Development }-2014\end{array}\right.\end{array}\right.$}

May 8 - 10, 2014, Riga, University of Latvia

the 99 companies. Authors used Microsoft Excel for the preparation and presentation of the survey results. For the year 2007 authors were able to use the annual reports of only 75 companies as some companies were established during this period, the others did submitted paper report, but the date of submission was not clear and for some companies no reports were found in the database. For year 2011 and 2012 the authors could use the reports of 98 companies for the present research.

It is also important that the number of the annual reports submitted on time has changed significantly in 2010, which in authors' opinion is directly related to the introduction of the e-reporting environment. Figure 1 illustrates the percentage of the annual reports submitted on time and with delay. It is obvious that the smallest percentage of the on time submitted reports occurred in 2009 (67.8\% or 59 reports from the total of 87), and this figure grew significantly in 2012 (89.8\% or 88 reports from the total of 98).

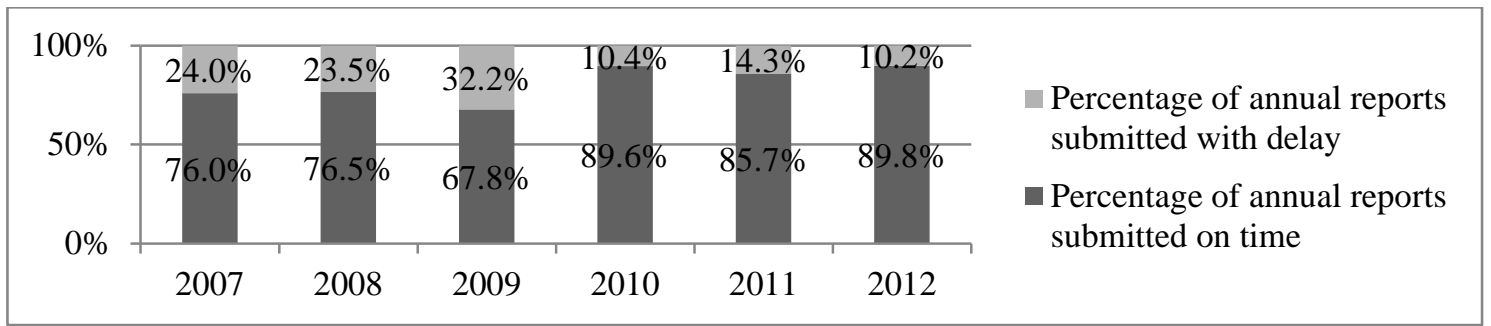

Source: author's construction based on Äripäev Information Base.

Fig. 1. Submission of Annual Reports during Years 2007-2012 by Estonian TOP 100 companies

The research confirmed that the number of the on time submitted annual reports has increased since 2010. The authors also found that the structure of the delayed submissions has changed. Normally, more than $50 \%$ of the delayed annual reports are submitted within one month after the stipulated period. It can also be stated that if the annual report is not submitted straight after the due date or with a short delay companies are no longer in a hurry and submit the report much later than requested only when they find a suitable time.

\section{Conclusions}

In conclusion it can be stated that in 2012 the large part of TOP100 companies (almost 90\%) have submitted their annual reports on time, which is definitely influenced by the implementation of the ereporting system.

\section{Bibliography}

eRIK Centre of Registers and Information Systems (RIK). e-Annual Report. [Online] Available at: http://www.egov-estonia.eu/xbrl [Accessed 20 November 2013].

Rätsep, K., 2010. Filing Annual Accounts Electronically in Estonia. Tallinn University of Technoogy, Department of Accounting. (Bachelor thesis).

Talv, P., 2011. Estonian e-annual Reporting Voted Best e-government Solution of the World. The Estonian Ministry of Justice. [Online] Available at: http://www.just.ee/54529 [Accessed 29 December 2013].

Äripäev Information Base (authors used the data of almost 600 reports).

Äripäev, november 2012. TOP100. [Online] Available at: http://leht.aripaev.ee/images/publication images/3b0915d6-57bc-451e-b5e4-edfc3f74d0e7-Paper/issue.pdf [Accessed 25 June 2013].

Mägi, M., e-Annual Report. [Online] Available at: http://www.wsis-award.org/winner/e-annual-report76320110609 [Accessed 29 December 2013]. 


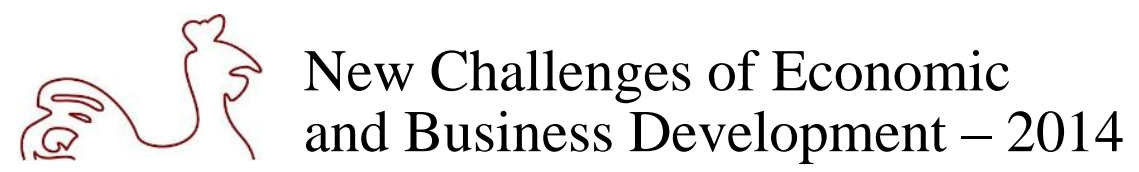

May 8 - 10, 2014, Riga, University of Latvia

\title{
IDENTIFICATION OF THE UZAWA-LUCAS MODEL FOR WORLD ECONOMY
}

\author{
Nicholas Olenev, Dorodnicyn Computing Centre of RAS, Russian Federation ${ }^{43}$
}

Key words: Uzawa-Lucas model, human capital, world economy, identification

JEL codes: C63, E20, O40

\section{Introduction}

The paper presents a method of parameter estimation for the Uzawa-Lucas model ((Uzawa H., 1965) and (Lucas R., 1988)) on the data of world economic statistics by application of high performance computations on multi-processors systems. The method determines unknown parameters of an economic model by indirect way comparing time series for macro indexes calculated by model with statistical time series for these indexes (Olenev N., 2009). This method of model identification differs from the direct methods of parameter estimation for specific countries are widely represented in the literature. For parameter estimation of the model you can see for example (Lucas R., 1988).

The Uzawa-Lucas model is solved from a centralized social planner perspective as well as in the model's decentralized market economy form. The model has two sectors: the human capital production sector and the physical capital production sector producing human capital and physical capital, respectively. Individuals allocate some of their time to producing final goods and dedicate the remaining time to training and studying. Parameter estimation is done for both version of the model each is described by three equations. Recall that parameters of the model are a technological level, a share of physical capital in world production function, value of human capital per person, fraction of labour time devoted to producing output, and externality parameter in the production of human capital, schooling productivity, depreciation rates, subjective discount rate and the inverse of the inter-temporal elasticity of substitution in consumption.

Parameter estimation for the model of global economic growth is extremely important in the current time of global economic crisis, because the identified model can be used for forecast of the future world development and can gives policy recommendations on economic policies for international organizations and for separated countries.

\section{Methods and results}

The Uzawa-Lucas model contains a lot of unspecified parameters. Some initial values of the model are also unknown and should be considered as parameters as well. In case of world economy mentioned parameters can't be defined directly on the basis of economic statistics. Moreover, even if all necessary statistics is available the quality of the data isn't good enough. That's why only confidence intervals for the unknown parameters can be directly computed from the statistical data. For estimation of the unknown parameters some time-series for macro indexes calculated by the model and statistical time-series for these macro-indexes should be compared by means of some measure of similarity. The unknown parameters can be determined implicitly as those parameters, which provide an extreme value of the used measure of similarity. Parallel processing on a cluster of workstations or

${ }^{43}$ Corresponding author - e-mail address: nolenev@ mail.ru, phone number: +7 4997833328 


\section{$\left\{\begin{array}{l}3 \\ 5\end{array}\right.$ New Challenges of Economic and Business Development - 2014}

May 8 - 10, 2014, Riga, University of Latvia

on a supercomputer enables to perform exhaustive search of the parameters within their confidence intervals (determined either from economic sense or from the available statistical data) and estimate their values for reasonable time.

It was mentioned that calculated and statistical time-series for some macro-indexes should be compared on the basis of some measure of similarity. As used here, two time-series are considered to be similar if they are close as functions of time (in other words, if there is a strong, possibly nonlinear dependence between two time-series). The Theil index of inequality $H_{X}$ is used as a characteristic of closeness between two time-series, in our case of time series for a macro index $X(t, \vec{a})$ calculated by the model with parameters $\vec{a}$ and its statistical analogue $X_{s}(t)$ and the more close it is to zero, the more close compared series are.

$$
H_{X}=\sqrt{\sum_{t=t_{0}}^{T}\left(X(t, \vec{a})-X_{s}(t)\right)^{2} / \sum_{t=t_{0}}^{T}\left(X^{2}(t, \vec{a})+X_{s}^{2}(t)\right)}
$$

For uniqueness of choice for optimal point it is possible to use some convolution of Theil indexes for time series of compared macro indexes. For example, if for all macro parameters the adjustment of estimated by model and statistical data has about equal importance, it is possible to maximize the value of all indexes by choice of parameters $\vec{a}$.

$$
K(a)=\prod_{X}\left(1-H_{X}\right) .
$$

Calculations were made on supercomputer at Joint Super Computer Centre of Russian Academy of Sciences.

\section{Conclusions}

The technology of model external parameter estimation is based on use of high-speed parallel calculations on multiprocessing systems. Estimated values of the parameters give new knowledge about the world macroeconomic system. Identified model can be used for forecasting and for economic policy recommendations.

The work is in part supported by the Russian Foundation of Basic Research (Grants 12-01-00916, 13-07-01020); by Program of Basic Research of Presidium of the Russian Academy of Sciences no. 15, and by Program of Basic Research of Section for Mathematics of the Russian Academy of Sciences no. 3.

\section{Bibliography}

Olenev, N., 2009. A Normative Dynamic Model of Regional Economy for Study Economic Integrations. 50 years of European Union. Rijeka (Croatia): University of Rijeka, pp. 25-34.

Lucas, R., 1988. On the Mechanics of Economic Development. Journal of Monetary Economics, 22(1), pp. 3-42.

Uzawa, H., 1965. Optimum Technical Change in an Aggregative Model of Economic Growth. International Economic Review, 6, pp. 18-31. 


\title{
$\left\{\begin{array}{l}3 \\ 5\end{array}\right.$ New Challenges of Economic and Business Development - 2014
}

May 8 - 10, 2014, Riga, University of Latvia

\section{THE LAEKEN INDICATOR: REGIONAL COHESION (DISPERSION OF REGIONAL EMPLOYMENT RATES)}

\author{
Rita Ozolina, University of Latvia, Latvia ${ }^{44}$
}

Key words: employment, regions, variation

JEL code: J17

\section{Extended abstract}

The object of previous research of the author has been social economical indicators of different types of households of Latvia, viewed by its regions. Object of this research also is households of different regions of Latvia, but its subject - level of employment in these regions, as one of 18 indicators of Laeken.

In December 15th, 2001 during the meeting of European Council in Laeken, where the name of this indicator comes from, the "Declaration about future of European Union" was accepted. This document appointed that European Union, including Latvia, has to become more democratic, transparent and efficient. This is the substantiation of the actuality of the topic of this research.

Eurocouncil of Laeken in December of 2002 supported implementation of 18 indicators which would help to monitor progress of meeting targets of social inclusion. Laeken indicators are the system of parameters meant for common statistical measurements of poverty and social exclusion within European Union.

Author has calculated one of Laeken indicators - variety coefficient of employment. These calculations are based on Laeken indicator's detailed parameter calculation's methodology published in $28^{\text {th }}-29^{\text {th }}$ April, 2013 by European Commission Eurostat's workgroup, named "Statistics on income, poverty and social exclusion".

The coefficient of variation is the Standard Deviation divided by the Arithmetic Mean, as follows:

$$
\text { C.V. of regional employment rates }=\frac{\text { Standard Deviation of regional employment rates }}{\text { ArithmeticMean of regional employment rates }}
$$

The Standard Deviation is the square root of the Variance. The Variance is calculated as the sum of the population weighted, squared difference of the employment rate for each region from the Arithmetic Mean, as follows:

$$
\text { Variance of employment rates }=\sum_{\text {regions }}\left[\frac{Y i}{\sum Y}(X i-\bar{X})^{2}\right],
$$

where $\bar{X}$ is the arithmetic mean of $\mathrm{Xi}$ and $\mathrm{Xi}$ is the regional employment rate for region $\mathrm{i}$ and $\mathrm{Yi}$ is the population aged 15-64 for region $i$.. Note that this is a departure from the standard calculation of the Variance (sum of the squared difference of the employment rate for each region from the Arithmetic Mean, divided by the number of regions).

${ }^{44}$ Corresponding author - e- mail address: rita.ozolina@lu.lv, phone number: +371 26132277

Rita Ozolina 


\section{$2\{3$ New Challenges of Economic and Business Development - 2014}

May 8 - 10, 2014, Riga, University of Latvia

The Arithmetic Mean employment rate is calculated using the total population, as follows:

Arithmetic Mean employment rate $=\frac{\sum_{\text {allregions }} X i}{\sum_{\text {allregions }} Y i}$

where $\mathrm{Xi}$ is the persons aged 15-64 who are in employment and $\mathrm{Yi}$ is the total population of persons aged 15-64.

Note that this is a departure from the standard calculation of the Arithmetic Mean (sum of the employment rates for each region, divided by the number of regions).

The employment rate represents persons in employment as a percentage of the population of working age.

$$
\text { Employment rate }=\frac{\sum X i}{\sum Y i},
$$

where $\mathrm{Xi}$ is the persons aged 15-64 who are in employment and $\mathrm{Yi}$ is the total population of persons aged 15-64.

Necessary information for calculating variety coefficient of level of employment in regions can be found in databases of CSB. This information is: level of employment, number of population in workingage (in regions and in country). Weighted dispersion and standard deviation was being calculated. Level of employment in regions, or regional cohesion was being calculated as variety coefficient, by dividing standard deviation with arithmetic average. If there is information about standard deviation, also standard error and confidence intervals can be calculated.

Calculations were done for years 2011 and 2012.

Main conclusions are following: level of employment has increased from $60.8 \%$ in year 2011 to $63 \%$ in year 2012. With confidence of $95 \%$ it can be affirmed that in regions of Latvia, in year 2011 level of employment was between $58 \%$ to $63 \%$, but in year 2012 - between $60 \%$ to $66 \%$.

Variety coefficient on level of employment in year 2011 was $4.9 \%$, but in year $2012-5.7 \%$. These variety coefficients tell that there is little variety. In both years, breakdowns of regional level of employment can be called stable, but it has to be pointed out that in year 2012 there was little increase in level of relative employment - increase by $0.8 \%$.

Results of this research can be used in practice. 


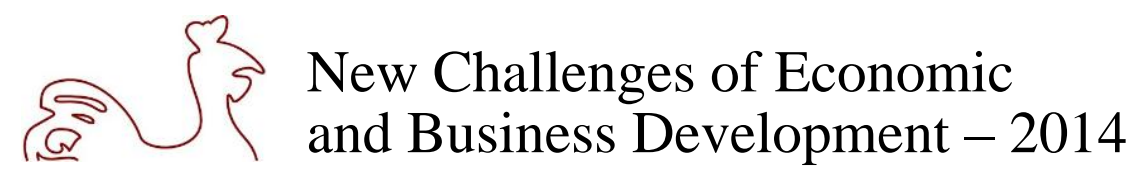

May 8 - 10, 2014, Riga, University of Latvia

\title{
CROSS-BORDER LABOUR MOBILITY AS A NEW CHALLENGE FOR ECONOMIC AND BUSINESS DEVELOPMENT
}

\author{
Tiiu Paas, University of Tartu, Estonia ${ }^{45}$ \\ Mart Kaska, University of Tartu, Estonia
}

Key words: international mobility of people, free movement of labour, economic development

JEL codes: J08, J23

\section{Introduction}

New business challenges and future economic growth are noticeably affected by the international mobility of people, particularly in the conditions of unfavourable demographic situation in the majority of the European countries. With the enlargement of the EU in 2004 and the gradual opening of labour markets to foreign workers, different forms of international labour movement besides permanent migration have received increasing attention. Non-permanent migration includes temporary, repeated, circular and contract migration, and also long-distance commuting between countries.

Cross-border labour mobility is an increasingly common form of international mobility of labour encouraged by the EU enlargement and free movement of labour. At the same time, research on crossborder labour mobility, including commuting, at the EU level has been rather scarce so far. This paper aims to explore some patterns of international labour mobility looking for an answer to the question whether cross-border labour mobility can pursue win-win expectations of increasing international labour movement after the EU eastward enlargement.

\section{Methods and results}

The empirical part of the study relies on diverse data sources including quantitative and qualitative information, e.g. statistical information, CV market data and interviews of people involved in the labour mobility between neighbour countries. Estonia as a country with quickly increased emigration, high number of cross-border commuters and also with increasing return migration, provides certainly an interesting case for examining new patterns of international labour mobility. By analysing the data of cross-border labour mobility between Estonia and its neighbouring countries both quantitative (e.g. logistic regression) and qualitative methods are implemented.

The results of the study show that the possible consequences of cross-border labour mobility are twofold. On the one hand, cross-border labour mobility may support the economic development of both source and target country. For instance close proximity of wealthy neighbouring countries (like Finland and Sweden) provides an opportunity for Estonian workers to significantly increase their income and to avoid unemployment, particularly in the rural areas, and thereby diminishes pressure on the Estonian social system. The neighbouring countries Latvia and Russia mainly attracted better educated and well qualified Estonian workers, who got new challenges for developing their skills and obtaining experience of working in a new business environment. As a rule, such workers also earned salaries above the Estonian average thereby creating good preconditions for some new consumption demand in Estonia. Cross-border labour mobility provides possibilities to create new business networks and to get new

${ }^{45}$ Corresponding author - e-mail address: tiiu.paas@ut.ee

Tiiu Paas, Mart Kaska 
May 8 - 10, 2014, Riga, University of Latvia

working skills and experience that can be useful for continuing working career after returning to home country. Thus, in that sense cross-border labour mobility has a positive impact on the economic development of both the source and target countries.

One the other hand, the cross-border labour mobility provides some concern of brain waste taking into account the sharp increase of lower-skilled jobs of Estonian people who are working in economically well-developed neighbouring countries Sweden and Finland. People who are working in economically more developed countries have often jobs that are below their qualifications. The results of the study that relied on the interviews of Estonian people who are involved in cross-border labour mobility between Estonia and Finland show that despite some positive economic consequences of cross-border labour mobility, there are also serious negative consequences on the level of family life; often children and their education are the victims of this mobility pattern.

\section{Conclusions}

In conclusion, in order to achieve an expected win-win situation of the increasing international labour mobility, policy measures that support reducing possible skill mismatches and brain waste and create favourable preconditions for effective skills exchange should be further elaborated and implemented. Also the implementation of certain package of economic and psychological measures that support families and create favourable conditions for return migration are undoubtedly important in order to gain from cross-border labour mobility and provide new challenges and possibilities for economic and business development of the countries. 


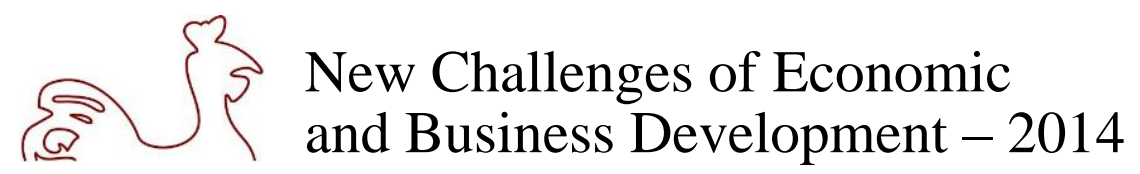

May 8 - 10, 2014, Riga, University of Latvia

\title{
GEORGIA: ENTREPRENEURIAL ECONOMY - ENTREPRENEURSHIP EDUCATION
}

\author{
Tatiana Papiashvili, International Black Sea University, Georgia ${ }^{46}$
}

Key words: entrepreneurial economy, entrepreneurship education, university business incubator, Georgia

JEL code: A20

\section{Introduction}

The World Bank sent the clear message to the government of Georgia, "The central challenge today for the government of Georgia is to find sources of long-run economic growth, particular through private sector development" (Fostering, 2013; p. 15). Georgia's economy is largely private sector economy. In 2011 the share of non-state enterprises was $99.3 \%$ of all registered enterprises (Entrepreneurship in Georgia, 2012). In this case, private sector development as a goal of the government policy has the only meaning - the shift to entrepreneurial innovative economy.

The array of surveys concerning doing business in Georgia shows that on business side there is a high unsatisfied demand for educated and skilled workforce, while on another side - education system that works "for itself" producing and supplying graduates without market-oriented skills. Besides the serious reform in education, the situation demands the creation of effective link between business and academic institutions. This function of being a bridge between education system and businesses, can be done by University Business Incubators (UBIs). UBI is a channel though which education can be directly transfer to business.

The importance of UBIs is widely recognized. In 2013 the first globally University Incubator Benchmark (UBI Index) was developed. Global index is used to benchmark performance and best practices of University Business Incubators (http://ubiindex.com/global-top-list-2013/).

The establishment of the UBIs is not a simple process and requires a complex analysis and research. Numerous factors (such as general business environment and SME sector in the country, quality of education and business education, existed links between business and academic communities, government special programs on business incubators and small business support, readiness of university and their students and their ambitions, etc.) should be discussed before making the decision.

The aim of the article is to analyze the entrepreneurial characteristics of Georgian economy and to build background for further development of entrepreneurial economy and entrepreneurship education through one channel - University Business Incubators.

\section{Methods and results}

In the paper quantitative and qualitative analyses of statistical data provided by National Statistics Office of Georgia and data of surveys conducted by the author, national researches and international organizations are applied.

The research includes brief overview of UBIs in the country. Based on undertaken research, the foundations of UBIs and road to further actions are defined.

${ }^{46}$ Corresponding author - e-mail address: t.papiashvili@ibsu.edu.ge, phone number: +995 571700647

Tatiana Papiashvili 


\section{2 $\{$ New Challenges of Economic and Business Development - 2014}

May 8 - 10, 2014, Riga, University of Latvia

\section{Conclusions}

In knowledge-based economy entrepreneurship and innovation are recognized as one of the crucial components of firms' and countries' competitiveness, economic development, and economic growth. Entrepreneurial economy roots in education system. Thus, the role, function and mission of universities in modern societies have been changed dramatically. With their traditional function of teaching / training and $\mathrm{R} \& \mathrm{D}$, universities have to take the lead in the knowledge / technology transfer process. The best organization form to realize this new function and mission is University Business Incubator model. UBIs operate as a bridge between entrepreneurial economy and entrepreneurship education.

The importance of BIs/UBIs for national economies, local businesses and communities, universities are widely recognized but not in Georgia. Unfortunately, even leading Georgian universities both state and private have not had UBIs as a part of their permanent organizational structure.

In such a situation, academicians have to attract attention of Georgian community, businesses and government to BI/UBI problem through:

1) analysis of international practice on advantages/disadvantages of BIs/UBIs;

2) launching of advantages of UBIs for all stakeholders as well as warming against possible difficulties;

3) research of perspective of establishment of UBIs in Georgia;

4) encouraging businesses and universities to establish BIs/UBIs by promoting incubation idea;

5) special government programs to support startups, financing, and management of the BIs/UBIs;

6) international support providing with related projects and grants.

\section{Bibliography}

Entrepreneurship in Georgia: Statistical Publication, 2012. Ministry of Economic Development of Georgia, Department of Statistics.

Fostering Entrepreneurship in Georgia, 2013. IBRD/WB. 


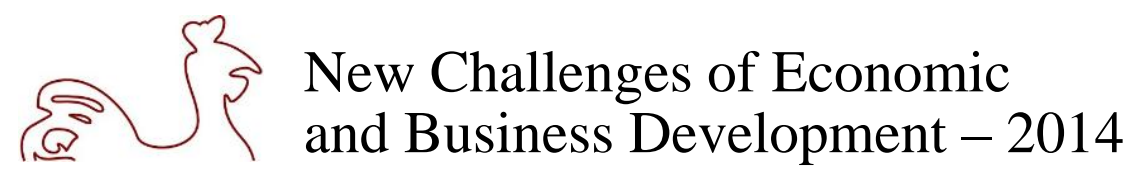

May 8 - 10, 2014, Riga, University of Latvia

\title{
FINANCIALIZATION IN TRANSITION: A CRITICAL ANALYSIS FROM THE PERSPECTIVE OF INTERNATIONAL POLITICAL ECONOMY
}

\author{
Leonardo Pataccini, University of Buenos Aires, Argentina ${ }^{47}$
}

Key words: Transition; financialization; International Political Economy; Eastern and Central Europe

JEL code: F59

\section{Introduction}

The paper presented here intends to investigate how structural reforms applied in the transition processes of the centrally planned economies from Central and Eastern Europe (CEE) into to market economies promoted their financialization. According to Epstein (2002) financialization "refers to the increasing importance of financial markets, financial motives, financial institutions and financial elites in the operations of the economy and its governing institutions, both at the national and international levels". Lapavitsas (2009) states that financialization provided the opportunity to agents engaged in the financial sector to get high returns made in the process of circulation of capital, to the detriment of other sectors. Meanwhile, Gabor (2012) points out that "the early period [of transition] could be read as a first stage in the financialization of the CEE economies [...]". Thereby, specific macroeconomic features of financializarion will be analysed in the paper.

\section{Method and Results}

After the fall of the Soviet Union there have been numerous scientific works on the causes of the collapse, transition and evolution of formerly centrally planned economies from CEE. However, the majority and the most influential of the works in the economic field have been made from an orthodox neoliberal theoretical perspective ${ }^{48}$. Therefore, the aim of the paper presented is to analyse the financialization of CEE economies from a critical approach, as part of a global-historical process. To meet the objectives, the research is done from the perspective and methodology of the International Political Economy. It uses a multidisciplinary approach that includes contributions from political economy, sociology, anthropology, social history and political science (Shields, 2012; O'Brien, 2010). To develop the different levels of analysis quantitative and qualitative data is used. For quantitative data the sources used are macroeconomic indicators from public and private databases and statistical series. The main indicators analysed are GDP evolution, inflation, gross national savings, external debt and current account. For qualitative analyses economic policy and regulations issues will be addressed. Both will be analysed in an articulated and dynamic way.

\section{Conclusions}

The paper argues that orthodox and mainstream explanations on the collapse of European centrally planned economies and the subsequent analysis of their transitions show serious theoretical

\footnotetext{
${ }^{47}$ Corresponding author - e-mail address: lpataccini@gmail.com, phone number: +371 27166430

48 Among many others, see: Lipton and Sachs, 1990; Blanchard et al., 1991; Kornai, 1994; Blanchard, 1997; Fischer et al., 1997; Roland, 2000; Campos and Coricelli, 2002.
} 


\section{$\left\{\begin{array}{l}\left\{\begin{array}{l}\text { New Challenges of Economic } \\ \text { and Business Development }-2014\end{array}\right.\end{array}\right.$}

May 8 - 10, 2014, Riga, University of Latvia

limitations. The main one is that their analyses are notoriously ahistorical and they don't not take sufficiently into consideration the influence of the global context. By contrast, the article submitted states that, among several other causal factors, both events are embedded within the financialization of the global economy.

The main findings of the research are: a) the specific set of structural reforms applied favoured the financialization of CEE economies. b) Financialization increases the exposure of CEE economies to external shocks by two channels: commercial and financial. It is considered that these findings may be a valuable contribution to understand the past of these countries, to analyse more effectively their current situations and their possible futures.

\section{Bibliography}

Anderson, P., 2003. Neoliberalismo: un balance provisorio. In the book: La trama del neoliberalismo. Mercado, crisis y exclusión social. Emir Sader (comp.) y Pablo Gentili (comp.). Buenos Aires: CLACSO.

Blanchard, O., 1997. The Economics of Post-Communist Transition. Oxford: Clarendon Press.

Blanchard, O., Dornbusch R., Krugman P., Layard R. and Summers L., 1991. Reform in Eastern Europe. Cambridge: MIT Press.

Campos N. \& Coricelli F., 2002. Growth in Transition: What We Know, What We Don't, and What We Should. [online] William Davidson Working Paper Number 470

Dragos Aligicia P. and Evans A., 2009. The neoliberal revolution in Eastern Europe. Cornwal: MPG Books Ltd.

Epstein, G., 2002. Financialization, Rentier Interests, and Central Bank Policy. [Online] Available at: http://www.peri.umass.edu/fileadmin/pdf/financial/fin_Epstein.pdf [Accessed 18 December 2013].

Gabor, D., 2012. The road to financialization in Central and Eastern Europe: the early policies and politics of stabilizing transition. Review of political economy, 24:2, pp. 227-249: Routledge.

Kornai, J., 1994. Transformational recession: The main causes. [Online] Available at: http://kornai-janos.hu/ Kornai1994\%20Transformational\%20recession\%20-\%20JCompEcon.pdf [Accessed 13 December 2013].

Lapavitsas, C., 2009. Financiarización, o la búsqueda de beneficios en la esfera de la circulación; Ekonomiaz N. $^{\text {o } 72 ;}$ 3.er cuatrimestre; pp. 98-119.

Lipton, D. y Sachs, J., 1990. Creating a market economy in Eastern Europe: the case of Poland. Brooking papers on economic activity, Volume 1990, Issue 1 (1990), pp. 75-147.

O’Brien, R. 2010. Global political economy: evolution and dynamics. New York. Palgrave Macmillan.

Roland, G., 2000. Transition and Economics: Politics, Firms, Markets. Cambridge: MIT Press.

Shields, S., 2012. The international political economy of transition: neoliberal hegemony and Eastern Central Europe's transformation. New York: Routledge. 


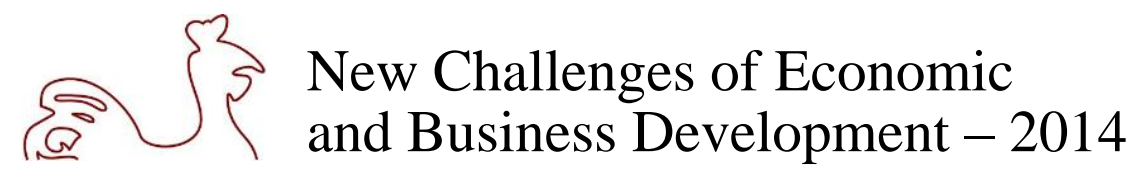

May 8 - 10, 2014, Riga, University of Latvia

\title{
LATVIAN PENSION SYSTEM: CALIBRATION BY CRISIS
}

\author{
Olga Rajevska, University of Latvia, Latvia ${ }^{49}$
}

Key words: pension systems, public pension, crisis

JEL code: H55, H75, J32

\section{Introduction}

Pension systems and their participants are functioning in a complex and constantly developing socioeconomic environment and have to tune themselves for those ever-changing conditions. Major systemic shocks like the recent crisis are serving as a very indicative test calibration of the overall security of a pension system and performance of its separate design elements. The aim of the author was to identify and to study the social and economic factors that are currently shaping Latvian pension 'terrain' (depopulation, globalisation of labour and financial markets, employment, public perceptions); how these factors had been effected by the crisis in short and long term; what participants of the pension system suffered most; and what lessons should be learnt and what measures should be taken in order to make Latvian pension system more secure.

\section{Methods and results}

The author studies the statistical data from national and international sources, publications of other researchers and examines changes in pension legislation driven by crisis.

Latvian pension system has three major participants (Bela B., 2013):

1. State (legislative and executive bodies).

2. Private pension funds (mandatory and voluntary).

3. Population covered by social insurance schemes.

As a rule, the first two are viewed when studying the effects of crisis on pension system. The author is paying the main attention to the third participant: what price the crisis years did take and still are taking from "a-man-in-the-street" pension. She distinguishes three subgroups within this group: 1) those retired before the beginning of crisis; 2) those went on pension during the crisis years; 3) future pensioners that are now in preretirement age. The effect of crisis shows up in different ways, as the role of certain socioeconomic factors varies between those subgroups significantly.

The author outlines the following major factors influencing Latvian pension system:

- Demographical factors: depopulation due to emigration and ageing is leading to increase of old dependency ratio. Both emigration and (consequently) ageing have been spurred by the crisis.

- Income gap between Latvia and Western Europe: pre-accession expectations of Latvian people concerning rapid shrinking of the income gap between "new" and "old" Europe after joining the EU have not materialised, so Latvians are "losing touch to their own development potential" (Scholz W., 2002). Crisis years with dramatic fall in GDP have moved the expected point of convergence even more away from today.

- Globalisation of labour market allows Latvians to use job opportunities abroad, and quite often their choice is motivated also by the reasons of better social guarantees in host countries.

${ }^{49}$ Corresponding author - e-mail address: olga@ livoniaship.lv, phone number: +371 29110545

Olga Rajevska 


\section{$\left\{\begin{array}{l}\left\{\begin{array}{l}\text { New Challenges of Economic } \\ \text { and Business Development }-2014\end{array}\right.\end{array}\right.$}

May 8 - 10, 2014, Riga, University of Latvia

- Globalisation of financial market and volatility of financial instruments make the assets accumulated in $2^{\text {nd }}$ and $3^{\text {rd }}$ pillar private pension funds very vulnerable to the risk of devaluation.

- Employment: high unemployment rates affect pension systems in three ways - firstly, paying out unemployment benefits to larger numbers of recipients depletes social budget thus complicating discharging obligations to existing pensioners; secondly, the unemployed persons make small or none contributions to their own future pensions; thirdly, Latvian pension formula automatically reduces future pensions for all future pensioners (even those having full employment and paying all taxes) through the mechanism of pension capital valorisation (indexation). Thus, the rise of unemployment in crisis years affected pension perspectives of all groups of population.

- Shadow economy causes considerable distortions in pension schemes: by working outside the active economy, participants can avoid taxes and social security payments. Saving money draws people into this other economy, especially during an economic downturn (Schneider F., 2013). The undeclared work results in lower contributions gathered from the working population, and affects both present and future pensioners in the same manner as high unemployment discussed above.

- Public perceptions: numerous data of public opinion polls show quite low level of confidence that Latvian people credit to the state pension system and perceive high degree of injustice in the country, those indicators are worsening in lean years. This increases the demand for pension reform.

\section{Conclusions}

No pension system in the world is immune from the global financial and economic crises. The governments have limited capacity to influence many of the above-mentioned factors directly. There are, however, suitable mechanisms and instruments for mitigating the undesirable effects on present and future pensioners by introducing and re-arranging specific elements of pension system design: raising of minimum pension levels, introducing of flat demogrant component, fair indexation rules; setting upper limits for pension funds administrative costs, etc. Last months have brought encouraging signs form Latvian politicians, demonstrating their willingness to initiate long-felt need for reforms in the pension system: the upper limit of wages subject to social insurance contributions is resumed, the Ministry of Welfare declared the coming revision of minimal pension regulations, the Ombudsman has commenced consideration of pension capital valorisation formula, more strict rules for private pension funds are being prepared. More equitable and solidary approach to public pensions should prevail for making the system robust to economic shocks.

\section{Bibliography}

Bela, B. (ed.), 2013. Latvija. Pārskats par tautas attīstību 2012/2013. Ilgtspējīga nācija. Rīga: LU Sociālo un politisko pētījumu institūts.

Schneider, F. 2013. The Shadow Economy in Europe. [Online] Available at: http://www.atkearney. com/financial-institutions/featured-article/-/asset_publisher/j8IucAqMqEhB/content/the-shadoweconomy-in-europe-2013/10192 [Accessed 08 January 2013].

Scholtz, W., 2002. Future visions for welfare states - developments in social protection policy in Europe. In Latvia Welfare Reform - Present and Future. Riga: Ministry of Welfare of the Republic of Latvia, UNDP. 


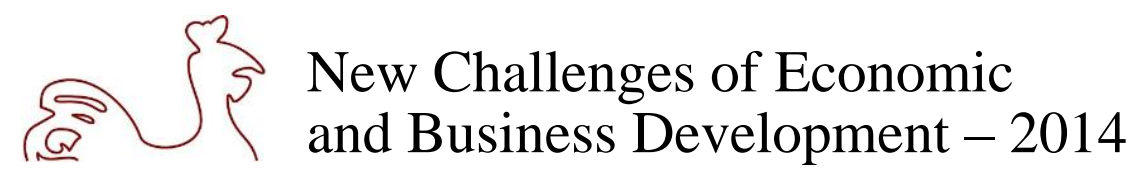

May 8 - 10, 2014, Riga, University of Latvia

\title{
IMPACT OF NEW DEVELOPMENTS IN DISTRIBUTION ON THE HOTEL INDUSTRY: A CASE OF LATVIAN HOTELS
}

\author{
Detlev Remy, Les Roches International School of Hotel Management, Switzerland; \\ Wolf Magnus Gerstkamp, Les Roches International School \\ of Hotel Management, Switzerland; \\ Evelyn Ebiner, Les Roches International School of Hotel Management, Switzerland; \\ Kristīne Bērziņa, University of Latvia, Latvia; \\ Ingrīda Millere, Latvia University of Agriculture, Latvia; \\ Linda Medne, Latvia University of Agriculture, Latvia
}

Key words: tourism, hotels, distribution system, online distribution systems, online distribution agency JEL code: M31

\section{Introduction}

In present times the hotel industry faces a wide choice and variety of distribution channels, both traditional offline and online. Online travel agents (OTA) and global distribution systems (GDS) (Unwin, 2013, Vinod, 2009) have built on their dominant position. Furthermore, new developments such usergenerated-content websites and others may replace traditional ways of distribution. Although the ongoing and rapid increase of sales through online travel agents has caused shifts in the market demands of electronic distribution over the past years, online channels have become vitally important as a big part of today's customers decision-making process of their travel bookings. In the US hotel sector, online sales can now account for over $50 \%$ of a typical hotel's room revenue and $35 \%$ of bookings flowing through online channels are not unusual for European hotels, with significant further growth certain in the short run. The biggest industry players or we could call them even giants are Expedia and Booking.com, both being major suppliers of business to the majority of European hotels. These two companies collectively control over $65 \%$ of European indirect online hotel sales (Hotel yearbook, 2013), although other more regionally focused companies like hotel.de and hrs.de do have significant share of customers in some countries.

The dominant position of some of the big players combined with market share and potential abuse of this situation, may create potential for new developments in hotel distribution, for example Google's Hotel Finder in 2011.

This research paper aims to thoroughly investigate these new distribution opportunities and developments. Moreover, the research team will analyse the acceptance and implementation of these practices.

Therefore, the research question arises to which extent any new distribution developments may affect the hotel industry, using a sample of Latvian hotels.

The findings of the research shall contribute to a better understanding of the current situation in the existing and new distribution management of the hotel industry and their willingness and acceptance of new practices.

\section{Methods and results}

Following an interpretivist research philosophy with a blend of deductive and inductive research, the researchers have applied qualitative research methods which included primary data collection that used 
May 8 - 10, 2014, Riga, University of Latvia

semi-structured interviews with hotel professionals. That said, a quantitative research approach would not be justified as the purpose of the paper is not to test any correlations between variables but to unfold attitudes, opinions and beliefs towards new developments in hotel distribution. The study itself is exploratory in nature as to identify new developments and trends currently in use by the hotel industry. The research instrument is divided in three parts, asking the participants for the current status, followed by an investigation into their distribution strategy and then finally investigating the area of conflicting issues in distribution such as rate parity and control.

Therefore, the authors are collecting rich data from a purposeful sample of 3-star and 4-star hotels in the geographical area of the Latvian capital of Riga. The data analysis follows Creswell (1998) recommendations to organize and categorize the qualitative data, to interpret and to identify pattern and similarities.

\section{Conclusions}

The main results and findings will be discussed and compared to existing research in order to develop in-depth understanding of existing and new distribution practices. Moreover, the findings will contribute to practice as to identify not only new distribution developments but to analyse their acceptance amongst hotels.

\section{Bibliography}

Anderson C.K., Yan R., 2010. Making the Most of Priceline's Name-Your-Own-Price Channel, Cornell Hospitality Report, Vol. 10, No. 13, pp. 1-13.

Anderson C.K, 2009. The Billboard Effect: Online Travel Agent Impact on Non-OTA Reservation Volume, Cornell Hospitality Research Summit Proceedings, Vol. 9, No. 16, pp. 1-10.

Christodoulidou N., Brewer P., Feinstein A.H., Bai B., 2007. Electronic Channels of Distribution: Challenges and Solutions for Hotel Operators, FIU Review, Vol. 25, pp. 92-100.

Creswell, J.W., 1998. Qualitative inquiry and research design: Choosing amongst five traditions, Thousand Oaks, CA, Sage.

Gazzoli G., Gon Kim W, Palakurthi R., 2008. Online distribution strategies and competition: are the global hotel companies getting it right?, International Journal of Contemporary Hospitality Management Vol. 20 No. 4, pp. 375-387.

Green, C.E., Lomanno, M.V., 2011. Distribution Channel Analysis: a Guide for Hotels, HSMAI Foundation, 203 p.

Hotel yearbook 2013. [Online] Available at: http://www.11Changes.com.

Pratt M, 2011. Breaking the Hotel Addiction to OTAs: A 3-step Recovery Plan customer relationship marketing that works, pp. 1-4. [Online] Available at: http://www.MadiganPratt.com.

Occupancy Marketing, 2013. Google Hotel Finder. [Online] Available at: http://www.occupancy marketing.com.

Tomlinson, P., 2013. Google Hotel Finder \& The War for Hotel SERP Listings. [Online] Available at: http://www.searchenginejournal.com/.

Vinod, B., 2009. Distribution and revenue management: Origins and value proposition, Journal of Revenue and Pricing Management Vol. 8, 2/3, pp. 117-133.

Withiam, G., 2011. Brave New World: Online Hotel Distribution, Cornell Hospitality Research Summit Proceedings Vol. 3, No. 4.

Unwin T., 2013. Hotel Distribution 500 Shades - Mostly Grey. [Online] Available at: http://www. rategain.com.

100 Detlev Remy, Wolf Magnus Gerstkamp, Evelyn Ebiner, Kristīne Bērziṇa, Ingrīda Millere, Linda Medne 
May 8 - 10, 2014, Riga, University of Latvia

\title{
ENHANCEMENT OF STUDY COURSE "INTERNATIONAL FINANCE" AS A PART OF THE BOLOGNA PROCESS ${ }^{50}$
}

\author{
Ramona Rupeika-Apoga, University of Latvia, Latvia ${ }^{51}$; \\ Edgars Brekis, University of Latvia, Latvia
}

Key words: international finance, study course, Bologna process

JEL codes: F30, I20

\section{Introduction}

The target of the Bologna Process is to create a European Higher Education Area (EHEA) based on international cooperation and academic exchange that is attractive to European students and staff as well as to students and staff from other parts of the world. One of the purposes of the Bologna Declaration (1999) was to encourage European cooperation in quality assurance of higher education with a view to developing comparable criteria and methodologies. In higher education, the term quality assurance refers to all the policies, ongoing review processes and actions designed to ensure that institutions, programmes and qualifications meet and maintain specified standards of education, scholarship, and infrastructure. In this respect, quality assurance primarily provides institutions and stakeholders in higher education with a guarantee that quality is being achieved (i.e. accountability). Quality assurance has also a function of enhancement and improvement of higher education system, institution, or programme.

The object of this research is the enhancement of study course "International finance" as a part of the Bologna process.

The purpose of this study is to improve the quality of study course "International finance" by providing a unified and coordinated approach of study process at the three Baltic States and German universities as a part of the Bologna process.

To achieve the purpose the following tasks were conducted:

1) to update the description of study course;

2) to review the background requirements of the course acquisition;

3) to improve the course outcomes, with a particular focus on the academic and professional competencies;

4) to improve the course topics, according to the latest topical issues in international finance;

5) to review the course requirements for obtaining credit points;

6) to update compulsory reading, further reading lists.

Quality assurance achievement is very complicated and a multifaceted task, that has to be done step by step. One of the first steps consists on participation of teaching staff from different institutions to devise the study course together, form joint study and examination requirements and participate in mobility for teaching purposes.

\footnotetext{
${ }^{50}$ This presentation of the Baltic-German University Liaison Office is supported by the German Academic Exchange Service (DAAD) with funds from the Foreign Office of the Federal Republic Germany.

This presentation reflects only the authors' views and the Baltic-German University Liaison Office is not responsible for any use that might be made of the content of the information contained in it.

${ }^{51}$ Corresponding author - e-mail address: rr@lu.lv, phone number: +371 29331977
} 


\section{2 $\{$ New Challenges of Economic and Business Development - 2014}

May 8 - 10, 2014, Riga, University of Latvia

\section{Methods and results}

Teaching staff from three Baltic universities: University of Latvia, Tartu University and Vytautas Magnus University and Siegen University from Germany have collaborated to develop new/updated study course "International finance". The research methodology used in this research starts with a literature review in order to compare and to analyse the study courses curriculums offered by different universities not only in Europe but in the world as well. On the basis of literature review to devise and improve the general course topics, according to the latest topical issues in international finance. After every course author from the three Baltic States and German universities had shared his teaching methodology and courses' syllabus, new/ updated "International finance" curriculum would be developed by providing a unified and coordinated approach of study process as a part of the Bologna process.

It is very important to review the study course curriculum every year and to collaborate with other teaching staff to achieve the Quality assurance and ensuring our students with actual information and the modern teaching techniques.

\section{Conclusions}

Main research findings:

1. The aim of the study course "International finance" is to provide theoretical knowledge and structural information about the unique "international" financial environments and associated opportunities and risks that confront international market participants. Throughout this course the globalization of today's financial markets has to be emphasized.

2. Course learning objectives:

- to develop an understanding and appreciation of the role of international financial environment within in the context of business activities:

- to develop an understanding of the domestic and global forces affecting financial markets and financial asset prices.

- to clarify the main tendencies and problems of formation of financial-banking services market;

- to develop a practical framework for the analysis of international capital markets including an understanding of forces affecting asset prices and possible models and approaches for forecasting asset prices.

- to develop students' understanding of current issues and use of relevant data in the area of international finance through regular readings and discussions of articles in the financial press and through the use of appropriate on-line web sites.

3. Devise of international, regional and local case studies.

4. Prepare the list of compulsory reading and further reading by emphasizing global and Baltic regional issues:

- Eiteman, D.K, Stonehill A. I. \& Moffett M.H., 2013. Multinational Business Finance. 13th Edition, Prentice Hall;

- Eiteman, D.K, Stonehill A. I. \& Moffett M.H., 2012. Fundamentals of Multinational Finance. 4th Edition, Prentice Hall, 544 p;

- International Finance, 2009. Edited by Kirton J. Farnham, Surrey; Burligton, VT, Ashgate, 555 p

- Valdez, St., 2007. An Introduction to Global Finansial Markets- 5th ed., Palgrave, 384 p.

- Maurice, D. L., 2009. International Finance. 5th ed., Routletge, (section I, IV), 586 p.

- Rupeika-Apoga, R. \& Zelgalve, E., 2009. Finanšu tirgus un tā analīzes metodes. LU Akadēmiskais apgāds, 117. lpp.

- Rupeika-Apoga, R., 2006. Tirdzniecība ar valūtu kā uzņēmējdarbības veids. Mācību līdzeklis, Rīga: Datorzinību Centrs, 340 lpp. 


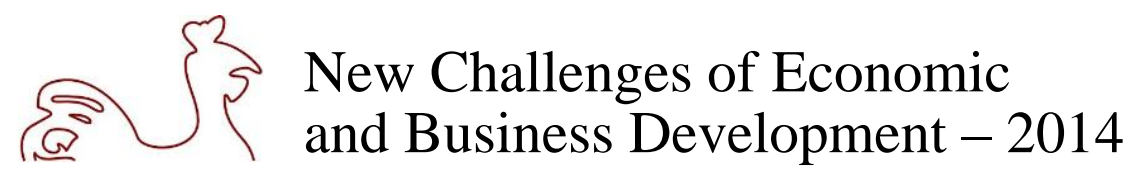

May 8 - 10, 2014, Riga, University of Latvia

\title{
FOREIGN EXCHANGE RISK MANAGEMENT IN NON-FINANCIAL COMPANIES: CASE OF THE BALTIC STATES
}

\author{
Ramona Rupeika-Apoga, University of Latvia, Latvia ${ }^{52}$ \\ Roberts Nedoviss, University of Latvia, Latvia
}

Key words: foreign exchange risk, risk measuring and exposure, VaR methods, non-financial companies

JEL codes: G32, F31

\section{Introduction}

Since mid-2008, foreign exchange markets have become more volatile due to the financial crisis in 2008 and the currencies wars. Generally, risk contribution from unhedged currency exposures will be higher than it has been in the past. For this reason foreign exchange risk management may be more of a priority than ever.

Nowadays companies face the challenge of evaluating the potential loss of transactions, especially in light of the recent financial crisis that showed what can happen as a result of poor risk management policy. Value-at-Risk holds a special place in the risk management - it is used almost everywhere. VaR is particularly important because it is used to calculate the market risk component of regulatory capital under the Basel Committee and it is one of the most applied in portfolio theory of investment, financial control and financial reporting as well. In this paper the authors have applied VaR methods for nonfinancial companies' foreign exchange exposure measurement.

As a misleading VaR estimate can lead to bad judgement on foreign exchange exposure and, consequently, to bad risk management, there is a need for an examination of VaR applications in the context of Baltic non-financial companies. The measure of foreign exchange exposure lies in the variety of difficulties. First of all, there are no single unambiguous methods how to measure risk, as some methods may produce different results. Secondly, each method has its own gaps.

The object of this research is foreign exchange risk measurement and management for the Baltic States companies.

The purpose of this research is by analysing different issues relating to the measurement and management of foreign exchange exposure to put forward offers how should Baltic companies manage their open currency positions.

To achieve the purpose the following tasks were conducted:

1. Analysis of the theoretical aspects of the measuring and managing currency exposure.

2. Analysis of Baltic companies' financial reports data to clarify risk management activities.

3. Clarifying firm' attitudes towards foreign exchange risk management in the Baltic States.

4. Estimating VaR methods to measure foreign exchange risk.

5. Development of recommendation how should Baltic companies manage their open currency positions.

${ }^{52}$ Corresponding author - e-mail address: rr@lu.lv, phone number: +371 29331977

Ramona Rupeika-Apoga, Roberts Nedoviss 


\section{$\left\{\begin{array}{l}3 \\ 5\end{array}\right.$ New Challenges of Economic and Business Development - 2014}

May 8 - 10, 2014, Riga, University of Latvia

\section{Methods and results}

The research methodology used in this paper starts with a literature review in order to highlight the difficulties faced by non-financial companies in identifying, measuring and managing foreign exchange risk. The analysis conducted in this paper is based on companies' financial reports data and statistics, and certain empirical studies. The data set is based on firms that were publicly listed on NASDAQ OMX Baltic Stock Exchange official list for the period spanning 2008 to 2012, excluding financial companiesbanks. The data were taken from the Nasdaq website.

The authors have analysed more than 30 Baltic companies and only some of them are using external methods of risk management, while the majority of companies prefer internal methods.

The main hedging strategies in our companies are following:

1. To sign contracts in EUR or other currencies hardly pegged to the euro.

2. To match assets and liabilities in EUR or currencies hardly pegged to the euro.

3. To net open foreign currency positions in currencies other than EUR, for example USD, UAH.

4. To limit open positions.

\section{Conclusions}

Baltic companies listed on NASDAQ OMX Baltic Stock Exchange official list are not using active risk management mostly due to the insignificance of foreign exchange risk, due to the assets and liabilities denomination in EUR or currencies hardly pegged to the euro; therefore they are treated as items free of foreign currency risk.

Additional reason for passive risk management is too expensive cost of implementing a currency hedge (transaction costs + interest rate differential between currencies) versus the expected risk contribution from unhedged currency risk.

Some of our companies' managers consider that the risk contribution from unhedged currency exposure is relatively low.

The analysis of the Baltic companies' foreign exchange risk exposure management practice shows that our companies are more passive than active. Companies' analysis has highlighted that generally managers in the Baltic countries do not seek to manage currency risk at all, especially smaller ones mostly because of the lack of knowledge how to manage risk at all. 


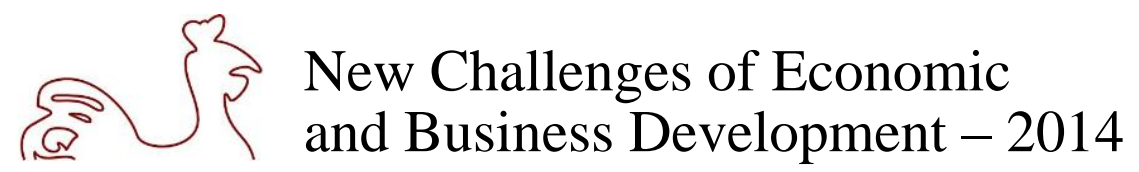

May 8 - 10, 2014, Riga, University of Latvia

\title{
PAID HEALTH CARE SERVICE PROVISION IN LATVIA - CUSTOMER SURVEY RESULTS
}

\author{
Didzis Rutitis, University of Latvia, Latvia ${ }^{53}$; \\ Anda Batraga, University of Latvia, Latvia
}

Key words: corporate identity, services marketing, health care

JEL codes: M14, M31, P46

\section{Introduction}

According to World Health Organization (WHO) and Eurostat official statistics, direct payments by patients (cash, private insurance, employers) to health care providers contributed close to $40 \%$ of total annual healthcare service expenditure in Latvia in 2010. Therefore, it is important to understand what factors health care enterprise management can improve and manage in order to meet expectations of patients regarding paid health care service delivery, thus, increasing customer satisfaction and increasing their revenues from health care service provision. The aim of the research is to determine those factors, which influence formation of the corporate identity of any health care enterprise in Latvia from the perspective of patients during paid health care service provision. The research tasks include survey of patients and statistical analysis (factor analysis) of the obtained research results. The survey structure is based on the communications process framework by Kupcs (1997) and the conceptual framework of corporate identity in health care industry introduced by Rutitis and Batraga (2013), derived from earlier research on corporate identity by Melewar (2003), and Abratt and Kleyn (2012).

\section{Methods and results}

The methodology employed in the work includes the data collection and data analysis and interpretation stages.

Data collection was implemented by using a quantitative research method - a health care service customer survey, which included 23 statements regarding various interaction and communication processes and relating to various health care provider's corporate identity dimensions perceived by the patients during the health care service provision process. Patients were asked to evaluate each statement using 5-point Likert scale. Total survey population was estimated to be 250'000; thus, covering all customers representing active labour force within the age range of 21-60, having permanent job and correspondingly possessing disposable income or/and private insurance for the paid health care service consumption. Survey was published online at www.webanketa.com and hyperlink to the web survey was sent out to 500 respondents online (users of Facebook, LinkedIn, and Draugiem.lv). In total, 477 responses were received, from which 440 were found out to be valid for further analysis. Therefore, response rate was estimated to be $440 / 500=88 \%$, which can be considered as satisfactory in order to attribute research results to the entire population. Such number of responses enables the authors to make conclusions regarding entire population with 95\% confidence level and $4.67 \%$ margin of error.

Collected data $(n=440)$ were processed using SPSS 19.0 software, and factor analysis was applied in order to identity the factors, which health care service customers regarded as important during health care

\footnotetext{
${ }^{53}$ Corresponding author - e-mail address: didzisr@gmail.com
} 


\section{$\left\{\begin{array}{l}\left\{\begin{array}{l}\text { New Challenges of Economic } \\ \text { and Business Development }-2014\end{array}\right.\end{array}\right.$}

May 8 - 10, 2014, Riga, University of Latvia

service provision. The survey responses were grouped in three groups, each representing statements regarding particular aspects of the communications framework - direct communication, interaction, and social perception (Kupcs, 1997). Kaiser-Meyer-Olkin (KMO) Measure of Sampling Adequacy was used to determine validity of the extracted factors and possibility of their usage in overall analysis of the survey results. Factors were extracted using principal component analysis. Rotation method Varimax with Kaiser Normalization was used to group the components / statements forming each factor.

Analysis of the interaction processes reflected high KMO value $(0.82)$ and two factors were obtained (patient awareness, attention and comfort) with high individual component factor loadings. Analysis of the social perception processes reflected medium KMO value (0.574) and two factors were obtained (service quality and reputation, marketing strategy) with high individual component factor loadings. Factor analysis of statements regarding direct communication processes reflected KMO value below 0.5, therefore, results were not used for further interpretation.

\section{Conclusions}

The extracted factors indicate the areas of improvement and follow-up and relate to specific corporate identity dimensions for any health care service provider in Latvia. The authors conclude that interaction factors (patient awareness, attention and comfort) directly relate to the patient service culture dimension, while social perception factors (service quality and reputation, marketing strategy) reflect importance of the dimensions related to corporate and internet communications, and scientific research from the conceptual framework of corporate identity in health care industry introduced by Rutitis and Batraga (2013). Authors suggest that these factors should be taken into account by the company management during health care service provision process development. Such conclusion is supported by Champy and Greenspun (2010), who point out that efficient health care provision can be attained by aligning people, processes and technologies.

Research results also suggest that from the marketing perspective, it is important to develop informative online website to establish efficient two-way communication channel with patients (including online sign-up sheet), and establish a single front desk (reception) phone number for enabling patients to access the necessary specialist or general practitioner with the least effort.

On the industry level, research results can be used to extend existing consumer surveys by professional industry associations (e.g. Patients' Ombud Office) in relation to health care service customer satisfaction evaluation.

\section{Bibliography}

Abratt, R., Kleyn, N., 2012. Corporate identity, corporate branding and corporate reputations: Reconciliation and Integration. European Journal of Marketing, 46(7), pp. 1048-1063.

Champy, J., Greenspun, H., 2010. Reengineering Health Care: A Manifesto for Radically Rethinking Health Care Delivery. FT Press.

Kupcs, J., 1997. Saskarsmes būtība. Rīga: Zvaigzne ABC.

Melewar, T.C., 2003. Determinants of the corporate identity construct: a review of the literature. Journal of Marketing Communications, 9(4), pp. 195-220.

Rutitis, D., Batraga, A, 2013. The conceptual framework of corporate identity in health care industry. In: Proceedings of the International Symposium ,, The Economic Crisis: Time for a paradigm shift towards a systems approach": Valencia, Spain. ISBN 978-8890-8-2421-0.

World Health Organization (WHO). [Online] Available at: http://data.euro.who.int/hfadb/ [Accessed 2 February 2014]. 


\title{
2 $\{$ New Challenges of Economic and Business Development - 2014
}

May 8 - 10, 2014, Riga, University of Latvia

\section{DUE DILIGENCE IN MERGERS AND ACQUISITIONS IN EMERGING MARKETS - EVALUATED RISK FACTORS FROM THE ACADEMIC AND PRACTICAL VIEW}

\author{
Alen Sacek, University of Latvia, Latvia ${ }^{54}$ \\ Key words: due diligence, emerging markets, mergers and acquisitions, risk, investment \\ JEL codes: G32, G34
}

\section{Extended abstract}

The obviously ever increasing number of corporate acquisitions in recent decades has widened and improved the general knowledge and awareness of due diligence audit in Mergers and Acquisitions process. In the current challenging business environment, acquisitions face higher degree of risk profiles, especially cross-border acquisitions in the emerging markets. Conducting a thorough due diligence investigation in the context of an acquisition is more important than ever.

This paper researches the key risk factors in the acquisition process and their assessment in the due diligence audit. The starting point is a meta analysis of the academic research findings which basically concentrate on common approaches considering financial, legal, commercial, and other issues in domestic acquisitions mainly in developed countries. Secondly, a number of business consulting firms have published studies about the success and risk factors in the acquisition process. Those studies are based on surveys which reflect typical risk factors consisting of i. e. regulatory issues, political factors, and litigation history etc. which may lead to commercial and reputational impediments in the acquiring process. The task of the paper is to match the academic and practical view in order to give a more complete understanding of risk factors to be covered in due diligence audit.

The outcome of the research shows additional risk factors to the academic one. Moreover, compared to the academic view of conducting due diligence, the practitioner's experience points to the fact that due diligence scope needs to be suited to the dynamics of the markets. The comparison calls for a different, a more integrated system of due diligence and shows herein the research deficit.

The originality of the paper is given by unique meta analysis of the acquisition due diligence literature and the selected consultant studies from anonymized practical experience based on insider information. The outcome is a compendium of evaluated risk factors which need to be included in each due diligence audit in the pre-acquisition phase.

\footnotetext{
${ }^{54}$ Corresponding author - e-mail address: alen.sacek@ gmail.com, phone number: +49 17634436347
}

Alen Sacek 


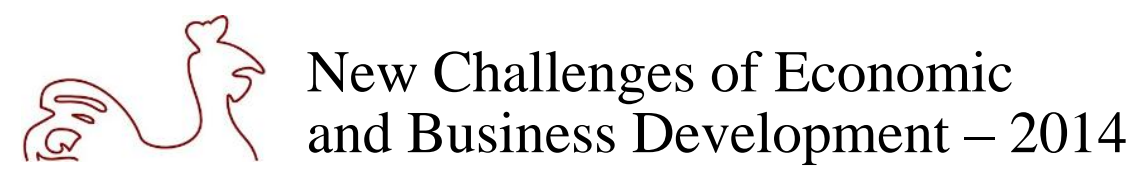

May 8 - 10, 2014, Riga, University of Latvia

\title{
LABOUR MARKET AS A PREREQUISITE FOR THE FORMATION OF THE KNOWLEDGE-BASED START-UPS
}

\author{
Timurs Safiulins, University of Latvia, Latvia ${ }^{55}$
}

Key words: entrepreneurship, innovation, labour market

JEL codes: O15, J24, F16

\section{Extended abstract}

Nowadays information is one of the most important resources and associated scopes has a significant share in any developed country's economy where economic growth in large extent is linked to the technological innovations. Information technology makes a rapid demand increase for new knowledge, competencies, skills, ideas in all types of companies and society in general. Taking into account technology availability, the key instrument is the human capital, i.e. qualified specialists creates a weighty perquisites for the formation and development of the knowledge intensive segment in the economy. It is certain that because of linkage to capital, knowledge and markets innovative business is beyond the national borders, but it is also certain that before holders change innovative project including management, project is usually based in the home country. And that is important because a large share of start-ups where specialists with high educational level are involved has a significantly positive impact on the regional development.

Regard to the pace of development of the IT segment, steady growth of demand for services as well as relatively low competition at the micro level, this area is attractive for such this type of companies as a start-ups. Globalization of technology and knowledge markets centralized specialist value in corporate innovation management. Technology especially in knowledge-based segment increased the mobility of innovation, start-up companies can create projects both for internal and external use also as share or access ideas. There are several distinctive features such as innovativeness, amounts of required starting capital and no need for a large number of specialists for the knowledge-based entrepreneurship. At the same time globalization and internationalization of markets has impact on all field of economy and forced many companies to outsource processes to increase performance reaching their objectives. Due to need for a cost-effective solutions, corporations are recruiting high-skilled specialist teams in countries with cheaper labour. In addition to the conductive climate for business, one of the key factors contributing to the pace of development of the mentioned field of entrepreneurship is a skilled workforce.

The objective of this research is to analyse labour market factors as a prerequisite for the formation of greater amount of in-country start-ups. In this article in order to reach objective author has analysed such factors as employment, unemployment, salary by sector and number of national companies across Baltic States using simplified search model.

\section{Introduction}

Modern generation is also known as "knowledge based society" because of a great number of hi-tech gadgets and inventions which are used to make everyday consumer's life better and easier. Within the demand for the knowledge-intensive products and services market expands and creates space for the new companies. The presence of human capital, i.e. skilled and educated workforce is one of the key factors of knowledgebased start-ups emergence, but on global market there is a number of large corporations that are eager for a cost-effective solutions and use to outsource various processes to the back offices in less developed countries.

${ }^{55}$ Corresponding author - e-mail address: timurs.safiulins@ gmail.com, phone number: +371 28350312

Timurs Safiulins 


\section{$\left\{\begin{array}{l}\left\{\begin{array}{l}\text { New Challenges of Economic } \\ \text { and Business Development }-2014\end{array}\right.\end{array}\right.$}

May 8 - 10, 2014, Riga, University of Latvia

Also in Latvia there is an option for a young specialist to join stable back-office team instead of joining local enterprise or create a start-up. Referred impugn the importance of the labour force as a major factor shaping local start-up companies in the segment of knowledge-based business. Therefore paper author decided to find in a scientific way the relationship between different factors in the context of knowledge-based business and determine the significance of the labour force as perquisite for the formation of local start-ups in the mentioned market segment using information and communication industry as a case-study.

\section{Methods and results}

Using qualitative research methods author processed information and communication industry's structural business statistics describing the structure, particular characteristics and performance of economic activities in the knowledge-intensive field across Estonia, Latvia and Lithuania also as analysed labour market size, structure and employment trends to evaluate the impact of regional employment on the growth of the start-up companies.

Table 1

Structural business statistics

\begin{tabular}{|l|c|c|c|c|c|}
\hline \multicolumn{1}{|c|}{ Country } & $\begin{array}{c}\text { Value } \\
\text { added } *\end{array}$ & $\begin{array}{c}\text { Number of persons } \\
\text { employed } * *\end{array}$ & $\begin{array}{c}\text { Average personnel } \\
\text { costs*** }\end{array}$ & $\begin{array}{c}\text { Enterprise birth } \\
\text { rates }^{* * * *}\end{array}$ & $\begin{array}{c}\text { Enterprise death } \\
\text { rates }_{* * * * *}\end{array}$ \\
\hline Estonia & 0.6 & 16 & 18.8 & 9.9 & 13.2 \\
\hline Latvia & 0.6 & 21 & 14.1 & 16.4 & 14.0 \\
\hline Lithuania & 0.6 & 24 & 12.1 & 14.7 & 32.1 \\
\hline
\end{tabular}

Notes: * EUR 1000 million; ** Number of persons employed, 1000 employees; ***Average personnel costs, EUR 1000 per year; ****\% \% onterprise births among active enterprises; *****\% of enterprise deaths among active enterprises.

Source: author's construction based on Eurostat Structural business statistics overview, available at: http://epp.eurostat.ec. europa.eu/statistics_explained/index.php/Structural_business_statistics_overview.

As the analysis of statistics shown there is a noticeable dispersion between number of employed also as an average personnel costs even within equal value added index, but Latvia has most positive ratio for enterprise birth/death rates that confirms assumption about opportune environment for start-up companies. Analysis within model leads to a similar conclusions. The used model leads to similar conclusions. In simplified equilibrium is might be presented as:

$$
P_{i}=\frac{V\left[\frac{L_{i}}{L_{x}}+\frac{L_{i}}{L_{y}}+\frac{W_{i}}{W_{x}}+\frac{W_{i}}{W_{y}}-\frac{U_{i}}{U_{x}}+\frac{U_{i}}{U_{y}}\right]}{n}
$$

where $\mathrm{P}$ is the portion of start-up companies against existing companies depending on 3 basic factors such as number of employed in sector $(L)$, unemployment rate $(U)$, relation of average salary across sector to average salary $(W)$ affecting individual decision to found a start-up or not to start one, in turn $V$ is used as a difference between enterprise birth and death rates and $n$ is total number of national enterprises over the sector.

Due to obtained results it is possible to assume that despite the negative performance of individual labour market factors for the formation of new knowledge intensive start-ups in Latvia and other Baltic States as well.

\section{Conclusions}

Due to high demand for innovative products and services, despite competition, there is a space for a newcomers on the global market. Preliminary results indicated the approval of the assumption that the labour availability is significant for start-ups, which in conjunction with other factors such as government support programs and opportunity for investment attraction, is relevant perquisite for the development of the knowledge-based business segment as a part of state economy.

Timurs Safiulins 


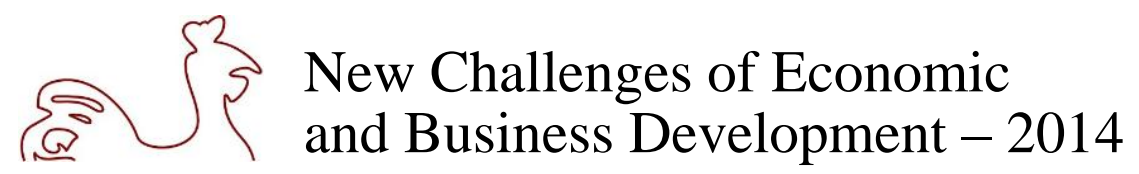

May 8 - 10, 2014, Riga, University of Latvia

\title{
ANALYZING SECONDARY PROFESSIONAL EDUCATION SYSTEMS IN KURZEME AND ZEMGALE REGIONS: INSTITUTIONS AND LABOR MARKET DEMAND
}

\author{
Svetlana Saksonova, University of Latvia, Latvia ${ }^{56}$
}

Key words: secondary professional education, demand for specialists, labour market

JEL codes: J2, I2

\section{Introduction}

The aim of this study is to analyse labour market demand for specialists with secondary professional education in Kurzeme and Zemgale regions, based on the results of surveys ${ }^{57}$ of students, lecturers involved in professional education and entrepreneurs in Kurzeme region. The surveys were conducted within the project "Research ${ }^{58}$ on the Responsiveness of Professional Education to the Needs of the Labour Market, Development of the Model of Cooperation and Organizing Training for Internship Managers".

The number of employed individuals in Kurzeme region's labour market has grown somewhat in 2012. According to the revised data of the Central Statistical Bureau (taking into account the results of the 2011 population census), the total number of employed individuals in Kurzeme has increased by 5.3 thousands from 2011 to 2012 . However, employment did not grow equally in every industry.

This paper considers several problems in the operation of professional education institutions and further progress of their graduates in the labour market. The most pressing issue is the decline in the number of students in professional education due to the low prestige of professional education. In addition, graduates of professional education programmes often end up working in different profession from the originally intended one.

\section{Methods and results}

In order to analyze labour market demand for specialists with secondary professional education, the author relied on the data from Central Statistical Bureau as well as analytical materials prepared by the Ministry of Economy, Ministry of Welfare and other sources. The paper applies statistical analysis methods on survey data as well as qualitative methods based on surveys and discussions of participants. The variety of education programmes on offer is sufficiently broad and overall corresponds to the priorities of the regions and designated priority industries.

\footnotetext{
${ }^{56}$ Corresponding author - e-mail address: svetlana.saksonova@lu.lv, phone number: +371 29653287

57 The survey of students, teachers, graduates and employers was developed by: Biruta Sloka, Ināra Kantāne, Ilze Buligina, Ginta Tora, Juris Dzelme, Svetlana Saksonova, Irina Bausova, Pēteris Tora, Iluta Skrūzkalne. The purpose of the survey was to establish how active is the cooperation with professional education institutions, what are the existing and potential forms of cooperation, how do the programs correspond to the demand of the labor market and municipal governments.

${ }^{58}$ The project "Research on the Responsiveness of Professional Education to the Needs of the Labour Market, Development of the Model of Cooperation and Organizing Training for Internship Managers" was implemented as part of the project LLIV-265 co-financed by the Latvia-Lithuania cross border cooperation programme 2007-2013, researchers: Ilze Buligina, Biruta Sloka, Juris Dzelme, Ginta Tora, Ināra Kantāne, Svetlana Saksonova.
} 


\section{2 $\{$ New Challenges of Economic and Business Development - 2014}

May 8 - 10, 2014, Riga, University of Latvia

\section{Conclusions}

The author provides recommendations to improve the connection between employers and professional education institutions, thereby increasing the flexibility of professional education institutions and their ability to react to the changes in labour market and the growth of demand for graduates of professional education in the labour market.

First, it is necessary to regularly analyse changes in the labour market as well as perspectives for economic development of the region.

Second, it is necessary to create new contracts with enterprises and industry professional associations on regularly raising qualifications of teaching staff to ensure their ability to prepare well qualified graduates of professional education system.

Third, it is necessary to analyse employment patterns of graduates in order to follow changes in the labour force.

Fourth, in addition to the existing open doors days, one has to create classes introducing and advertising different professions for matriculated students and their parents.

Fifth, it is necessary to intensify cooperation with employers, involving them into improving the content of education programs and supervising the quality of implementation, thereby ensuring that professional education students become well qualified specialists, whose skills are demanded on the labour market and match regional development trends.

Sixth, it is necessary to widen cooperation between regional professional education institutions and Latvian universities, for example by involving university academic staff in the development of educational materials. The cooperation between universities and professional education institutions could motivate graduates to continue their education in universities.

Finally, in order to ensure quality in teaching, professional education institutions need improvements in infrastructure and equipment. 


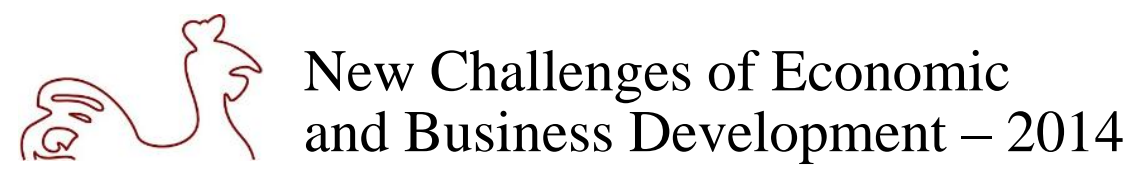

May 8 - 10, 2014, Riga, University of Latvia

\title{
SMARTPLS FOR THE HUMAN RESOURCES FIELD TO EVALUATE A MODEL
}

\author{
Tom Sander, University of Latvia, Latvia ${ }^{59}$; \\ Teh Phoey Lee, Sunway University, Malaysia
}

Key words: SmartPLS, PLS, SEM, Model

JEL codes: C52, M5

\section{Extended Abstract}

This paper describes the Partial Least Square (PLS) model to test the robustness and value of the statistical evaluation. The test is to evaluate the fit of the model of a small sample. The statistical data is calculated with the SmartPLS software. SmartPLS is a tool created for statistical analysis, namely PLS SEM (Structural Equation Model). The paper describes the advantages and disadvantages of SmartPLS and provides argument to use SmartPLS for the scientific world. At the moment concentrates the use of SmartPLS in the science mainly on the information technology field and the marketing area. The authors describe the use of SmartPLS for human resources area which is a new suitable field for SmartPLS software. Further describes the paper the validity and reliability for PLS - SEM.

SmartPLS is a second generation SEM tool. It calculates and tests models. SmartPLS has advantages and disadvantages for the research. The paper uses a model to measure social capital under consideration of the employment seeking process to demonstrate the method and to test the model. SmartPLS is a new product and mainly used in management and information systems environment.

The data for the test has been collected at the university Ludwigshafen in Germany. The validation and reliability has been done with the SmartPLS software from Ringle et al.

\section{The Advantages and Disadvantages of SmartPLS Software}

SmartPLS is a beneficial tool which is used in management science to calculate, create and validate models. Many articles use SmartPLS and journals accept SmartPLS as a evaluation tool (C. M. Ringle \& Sinkovics, 2009) (Shackman, 2013). The model explains causal mechanism and validates empirically theoretical hypotheses and applies predictions oriented measures. SmartPLS is a technique of the second SEM generation (Fuchs, 2011) (Chin, 2010).

The main area of SmartPLS is the field of Information Systems and Marketing. That is the reason to use this instrument and to test this instrument for the human resources and social capital field to open a new scientific field for SmartPLS. A study about social network sites or human resources related environment is not known yet. There are literature reviews which does not identify any study under consideration of the combination of social network sites, social capital and human resources(Hair, Sarstedt, Pieper, \& Ringle, 2012) (Shackman, 2013) (C. Ringle, Sarstedt, \& Straub, 2012). Therefore, this study will be a very novel approach in this area of study.

The advantage of this path modelling technique is the smaller sample size and a lack of distributional assumptions (Fuchs, 2011) (Chin, 2010) (Hair et al., 2012).

${ }^{59}$ Corresponding author - e-mail address: Stud.tom.sander@fh-kufstein.ac.at 


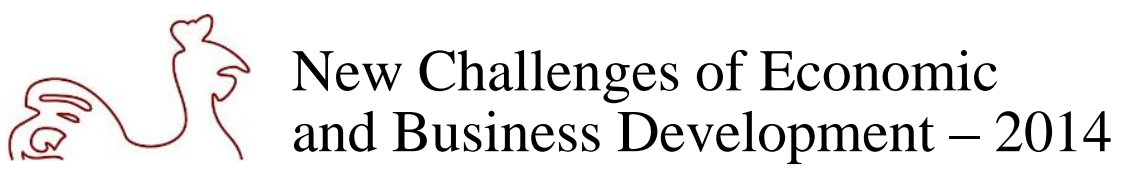

May 8 - 10, 2014, Riga, University of Latvia

SmartPLS has been used for exploratory research and theory development. That means SmartPLS can be used for scientific work with different objectives. The main contribution of SmartPLS is the prediction and opportunity to use non-normal data (C. Ringle et al., 2012). Furthermore, SmartPLS has the ability to use reflective and formative scales. Both can be tested with SmartPLS software and gives the opportunity to use a model with reflective and formative elements easily (Shackman, 2013).

\section{Result overview}

The overview of the results demonstrates that the model is robust and can be used for further research but the data needs further analysis.

Table 1

Measurement Overview

\begin{tabular}{|l|c|c|c|c|c|c|}
\hline \multicolumn{1}{|c|}{ Variable / Value } & AVE & $\begin{array}{c}\text { Composite } \\
\text { Reliability }\end{array}$ & R Square & $\begin{array}{c}\text { Cronbachs } \\
\text { Alpha }\end{array}$ & $\begin{array}{c}\text { Commu- } \\
\text { nality }\end{array}$ & $\begin{array}{c}\text { Redun- } \\
\text { dancy }\end{array}$ \\
\hline Activity & 0.6618 & 0.9313 & 0.4187 & 0.9131 & 0.6618 & 0.2731 \\
\hline Advantage / Benefit & 0.7307 & 0.8434 & 0.1619 & 0.6503 & 0.7307 & 0.1125 \\
\hline $\begin{array}{l}\text { Involvement / } \\
\text { Engagement }\end{array}$ & 0.7129 & 0.8322 & 0.3333 & 0.6002 & 0.7129 & 0.2362 \\
\hline Job Hunting & 0.7288 & 0.8865 & 0.3274 & 0.8149 & 0.7288 & 0.2268 \\
\hline
\end{tabular}

\section{Conclusion}

SmartPLS is a good tool to test a model and to describe complex structures. The software SmartPLS and model has not used in the research field of human resources under consideration of the employment seeking process and this is a novel research and method to create a new opportunity for this field. The flexibility of the SmartPLS software and less restricted rules enables scientists to explore causal mechanism with small samples and undistributed data which is very useful for this research.

\section{Bibliography}

Chin, W. W., 2010. How to Write up and Report PLS Analyses. In V. Esposito Vinzi, W. W. Chin, J. Henseler, \& H. Wang (Eds.), Handbook of Partial Least Squares, Heidelberg, pp. 655-685.

Fuchs, A., 2011. Methodische Aspekte linearer Strukturgleichungsmodelle Methodische Aspekte linearer Strukturgleichungsmodelle Ein Vergleich von kovarianz- und varianzbasierten Kausalanalyseverfahren. Würzburg.

Hair, J. F., Sarstedt, M., Pieper, T. M., \& Ringle, C. M., 2012. The Use of Partial Least Squares Structural Equation Modeling in Strategic Management Research: A Review of Past Practices and Recommendations for Future Applications. Long Range Planning, 45(5-6), pp. 320-340.

Ringle, C. M., \& Sinkovics, R. R., 2009. The use of partial least squares path modeling in international marketing. (J. Henseler, C. M. Ringle, \& R. R. Sinkovics, Eds.) New Challenges to international marketing, 20(2009), pp. 277-319.

Ringle, C., Sarstedt, M., \& Straub, D., 2012. A Critical Look at the Use of PLS-SEM. MIS Quarterly, 36(1).

Shackman, J., 2013. The Use of Partial Least Squares Path Modeling and Generalized Structured Component Analysis in International Business Research: A Literature Review. International Journal of Management, 30(3), pp. 78-86. 


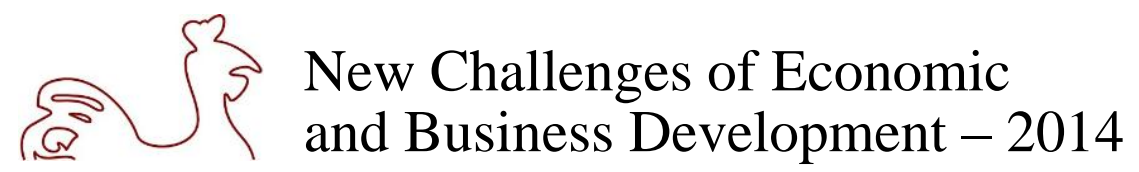

May 8 - 10, 2014, Riga, University of Latvia

\title{
DOES CULTURAL BACKGROUND AFFECT COMPLIANT BEHAVIOUR IN CHINA?
}

\author{
Barbara Scharrer, University of Latvia, Latvia; \\ University of Applied Sciences Kufstein, Austria
}

Key words: China, Compliance, Corruption, Hofstede, Ajzen/Fishbein

JEL code: D73

\section{Introduction}

Corruption is a widespread phenomenon in many countries and still a big problem in China. According to the Corruption Perceptions Index 2013 of Transparency International, which includes 177 countries, Germany was ranked on position 12 , China on position 80. International companies try to prevent corruptive behavior by introducing corporate compliance management systems at their Chinese subsidiaries, but new corruption scandals present themselves nearly daily and are often reproduced in the media.

International companies have to act compliant according to different national laws and regulations depending on the countries where they trade or establish a subsidiary. With the increasing level of internationalization it gets more and more complex for international companies to overlook the legal frameworks, but also the cultural implications in different countries (Weidlich T./Yates A., 2008). To only translate a German Compliance Management Codex into Chinese language and to publish this codex at the Chinese subsidiary of the German company doesn't seem to be not success to prevent corruptive behavior. Until now, academic research has focused very little on the role of local Chinese cultural values as a background factor in this regard.

The author's research aim is to investigate the relation of socio-cultural standards and professional compliant behavior such as to observe and to respect local Compliance regulations, implemented within a German subsidiary in China. The author's research will focus on the question of whether one can predict corruptive behavior with respect to certain background factors in China and - if so, - how from a company's point of view these background factors could be changed or redesigned to prevent corruptive behavior. The research question is whether local Chinese socio-cultural values may influence a potential corruptive behavior of Chinese employees in German subsidiaries. In-depth knowledge about sociocultural background factors and how they influence intentions and behavior of employees may help to reveal new approaches how to design, implement and control an effective Corporate Compliance Management System in China. The study aims to further explore the role national Chinese culture might play in explaining (non-) compliant professional behavior. This study links Hofstede's (1980, 2001) explanation of cultural dimensions and the values of Chinese Confucian tradition and philosophy (The network-based Chinese Social Capital - guanxi) with professional compliant behavior. The purpose of this study is to explore the extent to which differences in professional compliant behavior can be explained by differences in national culture according to Hofstede. Chinese social/personal networks guanxi have existed and been practiced for centuries and are products of specific cultural heritages. Confucianism places an emphasis on social capital and networking (Chen 2001; Haley et al., 2009).

The theoretical framework of this study regarding the behavioral approach will be based on the Theory of Reasoned Action/Theory of Planned Behavior by Fishbein/Ajzen (Ajzen I., 1991 and Ajzen I., Fishbein M., 1980). Determinants of individual-level behavior have long been of interest to 


\section{$\left\{\begin{array}{l}3 \\ 5\end{array}\right.$ New Challenges of Economic and Business Development - 2014}

May 8 - 10, 2014, Riga, University of Latvia

social scientists and many intention-based theories have been advanced. Among the most fundamental are the Theory of Reasoned Action and the Theory of Planned Behavior (Tang Z., Chen X., Wu Z., 2010).

\section{Methods and results}

This research theory will be tested by using a mixed methods research design. The author's research design will combine sequentially a quantitative and qualitative research approach. The author may start the research by quantitatively testing the research theory to measure the attitudes and predicted behavior of the employees to act compliant. This may be done by using a survey sent to at least a hundred employees, in China as well as Germany. In a next step, the author will conduct qualitative research methods, by using semi-structured interviews with at least about 15-20 employees in China and Germany. The author aims to converge quantitative and qualitative data in order to provide a comprehensive analysis of the research problem.

Data will be collected at several companies based in Germany with subsidiaries in China.

\section{Conclusions}

The results may help to find new concepts regarding the transferability of compliance management systems to China. The results may help to identify new approaches to increase effectiveness in prevention of corruption by predicting and changing individual non-compliant behavior. This is also the main novelty of this research.

\section{Bibliography}

Ajzen I., 1991. The Theory of Planned Behavior, Organized Behavior and Human Decision Process, 50(2), pp. 170-211.

Ajzen I., Fishbein M., 1980. Understanding attitude and predicting social behavior, New Jersey, Prentice-Hall.

Chen M.-J., 2001. Inside Chinese Business: a Guide for Managers worldwide, Boston, Harvard Business School Publishing

Haley G.T., Haley U.C.V. \& Tan C.T., 2009. New Asian Emperors: the Business Strategies of the Overseas Chinese, New York, Wiley.

Hofstede G., 1980, 2001. Culture's Consequences: Comparing Values, Behaviors, Institutions and Organizations across Nations. 2nd Edition, Thousand Oaks CA: Sage Publications, 2001.

Hofstede G., Minkov M., 2010. Cultures and Organizations: Software of the Mind, 3rd Edition, McGrawHill USA, 2010.

Tang Z., Chen X., Wu Z., 2010. Using behavior theory to investigate individual-level determinants of employee involvement in TQM, Total Quality Management, Vol. 21, No. 12, Dec. 2010, pp. 1231-1260.

Transparency International e.V., 2013, Corruption Perceptions Index - Country: China. [Online] Available at: http://www.transparency.org /country\#CHN [Accessed 8 January 2014].

Weidlich T./Yates A., 2008. Compliance - Auslandsrisiken erkennen und steuern. In: Compliance in der Unternehmenspraxis, hrsg. von G. Wecker, H. Van Laak, Wiesbaden, S. 99-118. 


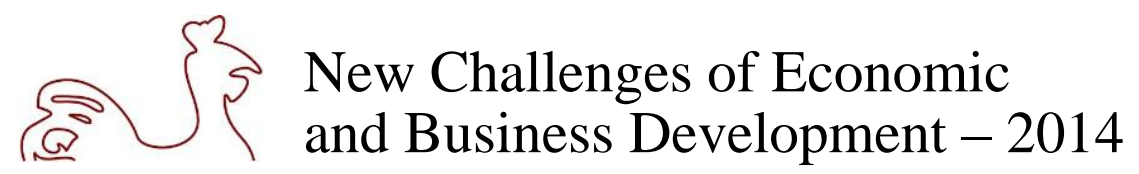

May 8 - 10, 2014, Riga, University of Latvia

\title{
OPPORTUNITIES AND TREATS FOR CONDUCTING MONEY LAUNDERING RISK ASSESSMENT METHODOLOGY IN BANKS
}

\author{
Iryna Semehen, Lviv banking institute, Ukraine ${ }^{60}$
}

Key words: money laundering, risk assessment, bank

JEL code: G210

\section{Introduction}

The problem of combating money laundering in financial institutions is always relevant, since this phenomenon is systemic. Studying these processes, scientists are developing new methods to counter, one of which is the risk-management. In this article, the system of financial monitoring of the banking institution is considered from the risk assessment, approaches and principles that are related. The process of implementing risk-based approach starts with a pre-determined list of identified generic risks or risk events.

The tasks of this research is: to study the types of risks that are inherent in the system of combating money laundering; to define the role of risk not only in banking institutions, but in the system of national risk assessment; to propose the definition of term "risk of legalization".

\section{Methods and results}

In this research we used such methodology as: causal-comparative methodology (to establish causeeffect relationships among the types of risks) and descriptive research methodology to define the term "risk of legalization" and to describe risk assessment methodology. There are a lot of different classifications of banking risks: credit, liquidity, money exchange, technical and others. Speaking on the analysis of risks inherent in the sphere of combating money laundering, there is no single, well-defined approach that would be inherent in all banking institutions. At the Core principles of effective banking supervision proposed by the Basel Committee, states that a bank must have adequate means and procedures to identify, measure, monitor and control risks (Basel Committee, 2006).

In the economic literature there are a lot of different classifications and approaches to understanding the nature of economic risks. Complex risk is associated with overcoming uncertainty and conflict in a situation of imminent choice and reflects the extent hoped for outcome achievement, failure, or deviations from targets, taking into account impact factors, the presence of forward and backward linkages (Partyn, Sloboda, Smovghenko, 2007). Adapting to the definition to the anti-money laundering, it is worth noting that when it comes to monitoring the financial transactions of banks, the degree of risk in some cases will not be shown in figures and have more abstract. This is due primarily to the fact that the losses incurred by the financial institution that will be used in a particular criminal laundering process, it will be very difficult to track or detect because they may not be reflected on the balance sheet, but on its reputation.

Given the definition of risk as the probability of the occurrence or non-occurrence of certain events, transactional monitoring of the banking institution is considering an approach that is based on an assessment of risk (risk of legalization), as the probability of detection or omissions of financial transactions, which could potentially be related to money laundering. Examining and taking into account all possible risks that arise in the course of AML that were obtained by criminal means, we did find some cause and effect relationships that occur in the event of certain types of risks. Take a look on a Figure 1 below.

${ }^{60}$ Corresponding author - e-mail address: dzedzyk-ira@ukr.net, phone number: +380 979474170 


\section{$\left\{\begin{array}{l}3 \\ 5\end{array}\right.$ New Challenges of Economic and Business Development - 2014}

May 8 - 10, 2014, Riga, University of Latvia

The bank's risk-based methodology should be related to national money laundering or financing of terrorism risk assessment methodology, follows closely principles established in international standards on risk. Identifying, assessing, and understanding ML/TF risks is an essential part of the implementation and development of a national anti-money laundering regime, which includes laws, regulations, enforcement and other measures to mitigate ML/TF risks.(FATF, 2013). The methodology should measures net money laundering risk, that is, the level of risk taking into account the effect of controls on inherent risk. Controls are implemented to reduce inherent risk; thus, they reduce, but their absence or poor effectiveness can never increase, inherent risk.

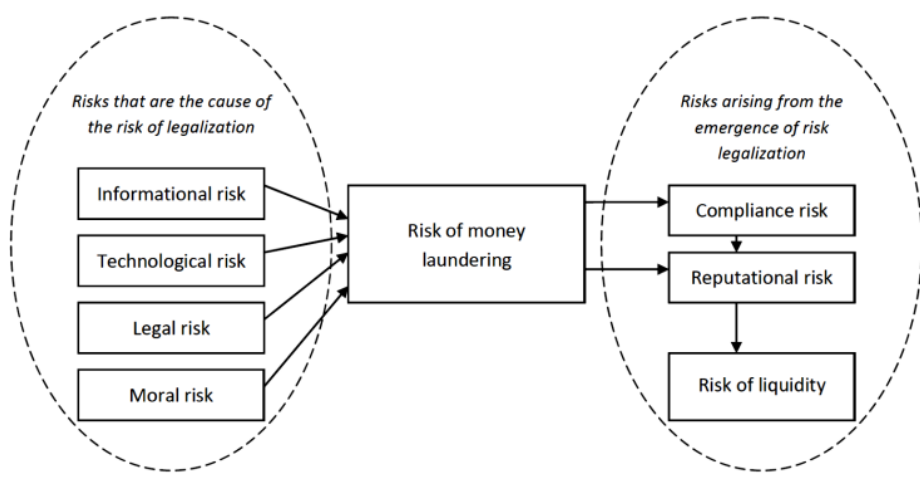

Source: author's construction

Fig. 1. Cause-effect feedback of money laundering risk

Figure 1 shows that the cause of the risk of legalization can be, for example legal risk, as the event of poor legal framework, an employee can drop out of sight of the important operation as a result - there is a risk of legalization of money from crime, which in the case of detecting money laundering fact is a risk of reputation, which in turn leads to lower public confidence in financial institutions and consequently, the risk of liquidity.

\section{Conclusions}

Theoretical and practical framework should be improved in financial monitoring system in banks, with implementation of risk-based approach in it. This research help to improve the economic categories, such as "transactional monitoring in bank" and "risk of using the bank for money laundering" and offered its own interpretation of the data terms. Formed theoretical cause-effect model, that characterize the risk of money laundering in banking institutions. In future propose to use correlation-regression model analysis, in terms of evaluation of financial operations of banking institutions. Such particular form of risk as money laundering risk, requires not only effective methods of evaluation and regulation, but a single, integrated approach that will be used by banking institutions in the implementation of financial monitoring function, and therefore attracts the attention of modern scholars worldwide.

\section{Bibliography}

Basel Cometee on banking supervision, 2006. Basel II: International Convergence of Capital Measurement and Capital Standards. [Online] Available at: http://www.bis.org/publ/bcbs128.htm.

Partyn G., Sloboda L., 2007. Interbanking supervision of credit risks: Monograph / Tamara Smovghenko. - K.: UB NBU, $254 \mathrm{p}$.

FATF, 2013. FATF Guidance National Money Laundering and Terrorist Financing Risk Assessment. [Online] Available at: http://www.fatf-gafi.org/media/fatf/content/images/National_ML TF_Risk_Assessment.pdf. 


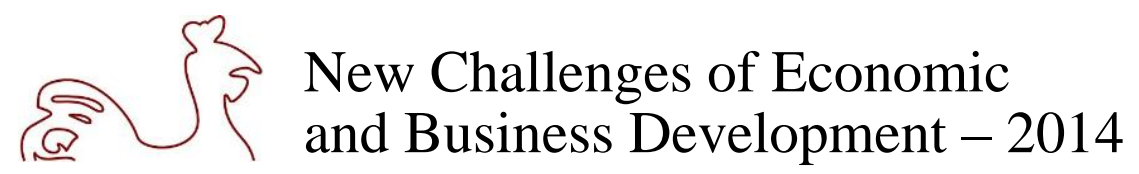

May 8 - 10, 2014, Riga, University of Latvia

\title{
ASSESSMENT AND RECOGNITION OF COMPETENCIES ACQUIRED IN NON-FORMAL EDUCATION: PERSPECTIVE AND PRACTICE OF LITHUANIAN UNIVERSITIES
}

\author{
Jolita Sinkiene, Kaunas University of Technology, Lithuania ${ }^{61}$; \\ Rasa Snapstiene, Kaunas University of Technology, Lithuania; \\ Ruta Petrauskiene, Kaunas University of Technology, Lithuania
}

Key words: non-formal education, life-long learning, assessment and recognition of competences

JEL code: I23

\section{Extended abstract}

Problem statement. Education is a lifelong process which enables the continuous development of a person's capabilities as an individual and as a member of society. It can have three main forms: informal, non-formal and formal education. Today, when most of the learning time takes place outside the formal curriculum and the specialized institutions, formal educational systems alone no longer can cover the learning needs of individuals or communities and respond to rapid and constant technological, social and economic change in society. Non-formal education is essential for the life-long learning and development of every individual and society as a whole. It is a necessary supplement to formal education. However, in many countries formal education institutions still have a monopoly on the provision of education as they have the power to certify learning outcomes.

One of the most important challenges for governments and appropriate authorities is to create a system for assessment and recognition of the value of non-formal education (European Youth Forum, 2006). From the other side, individuals wishing to pursue career shall have a possibility to receive a full recognition of his/her competences acquired in various non-formal education programmes and not to spend time and financial resources repeatedly when attending programs of higher education.

In 2006 European Parliament and of the Council of Europe established an action programme in the field of lifelong learning 2007-2013 aimed to develop and foster interchange, cooperation and mobility, so that education and training systems become a world quality reference in accordance with the Lisbon strategy and thus contributes to the development of the Community as an advanced knowledge-based society, with sustainable economic development, more and better jobs and greater social cohesion (European Parliament, 2006).

Lithuania, as other EU member states, has created a legal framework for regulation of assessment and recognition of competences acquired in non-formal learning. The importance of the non-formal education is emphasized in national strategic development documents. Yet, experts state that Lithuanian legal framework, although corresponds with general principles and guidelines of EU policies in this field, in reality is very fragmented and lacks systematic approach (Lukosiuniene V. 2010). As research results show, a number of institutions of higher education of Lithuania have established and implement their own systems, others are still in the process of design, or do not have this system at all. This impedes the possibility of individuals having a part of required competences to complete programmes of higher education and realize their intellectual potential.

${ }^{61}$ Corresponding author - e-mail address: jolita.sinkiene@ktu.lt, phone number: +370 69957102 


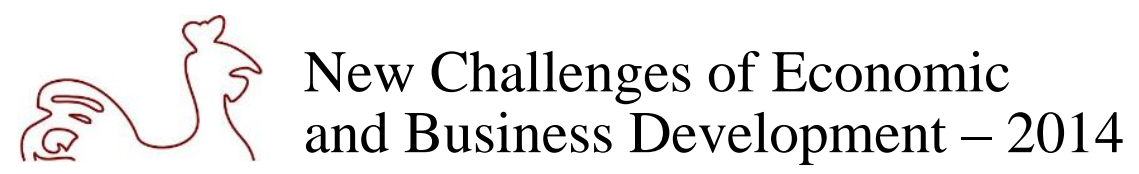

May 8 - 10, 2014, Riga, University of Latvia

Research aim - to identify best practices of Lithuanian universities in assessment and recognition of non-formal education outcomes and to develop recommendations for improvement of the process in Lithuania and other countries undergoing similar process. Research methodology: Analysis is based on cases of three major universities of Lithuania: two of them ((Mykolas Romeris University - MRU, Vytautas Magnus University - VDU) already have and apply regulations for recognition of non-formal education while Kaunas University of Technology (KTU) has only recently (in early 2014) presented its guidelines for the recognition procedure. Experiences of foreign universities in this field will be discussed in the paper as well. Methods applied for this research are: scientific literature analysis, document analysis, comparative case study analysis.

Main (preliminary) findings of the research are:

- The learning process can have formal, informal and non-formal forms. Non-formal education needs to go along with formal education and thus assure the accessible for all and lifelong process of learning. Non-formal education is defined as a "planned programme of personal and social education designed to improve a range of skills and competencies, outside but supplementary to the formal educational curriculum." (CoE, Committee on Culture and Education, 1999).

- In the last decade a large number of non-formal training programs have been implemented in Lithuania with the support of EU Structural Funds. It influenced the growing demand for recognition of non-formal education achievements in the educational market of the country. National authorities have introduced a general legal framework for assessment and recognition of the competences with the right of institutions of higher education to establish their own individual procedures of assessment and recognition. However the entire system is not functioning well. Its main problems are: large fragmentation, lack of sustainability, lack of public and private (individual) resources for implementation of the procedures, lack of information in the society, etc.

- Analysis of systems for assessment and recognition of non-formal education in three major Lithuanian universities showed that MRU has the longest history in assessing and recognizing the non-formal education of the applicants. VDU introduced the requirements in 2011; KTU introduced the main principles just in early 2014. VDU implements the system successfully, however, the number of applicants is rather small (an important reason - price of the service). System of KTU is more liberal than in VDU.

- Recommendations for improvement of the Lithuanian policy for non-formal education assessment and recognition will be provided in the final version of the paper.

\section{Bibliography}

Council of Europe, Committee on Culture and Education. Report on Non-formal Education. Doc. 8595. 15 December 1999. [Online] Available at: http://assembly.coe.int/ASP/Doc/XrefViewHTML. asp?FileID =8807\&Language=en [Accessed 21 March 2014].

Decision no 1720/2006/EC of the European Parliament and of the Council of 15 November 2006 Establishing an Action Programme in the Field of Lifelong Learning. [Online] Available at: http://eurlex.europa.eu/legal-content/EN/ALL/;jsessionid=Y2JyT4xZWgVnvGQYjD8gyKZPxsShQLQyT2Hrp QQL2Xq8TQX621dD!-2015871090?uri=CELEX:32006D1720 [Accessed 11 March 2014].

European Youth Forum. Council of Members Policy Paper on Youth Organisations as Non-formal Educators-Recognising Our Role, 21-22 November 2003. Rome (Italy). [Online] Available at: http://www. youthforum.org/assets/2013/12/Policy-Paper-Role-of-NGO-0618-03.pdf [Accessed 2 March 2014].

Lukošūnienė V. Neformaliojo ir savaiminio mokymosi pripažinimo situacijos Lietuvoje apžvalga. Suaugusiųjų neformalaus ir savaiminio mokymosi pripažinimas Informacinis leidinys. Sudarytoja Vilija Lukošūnienè. 2010, 11 p. 


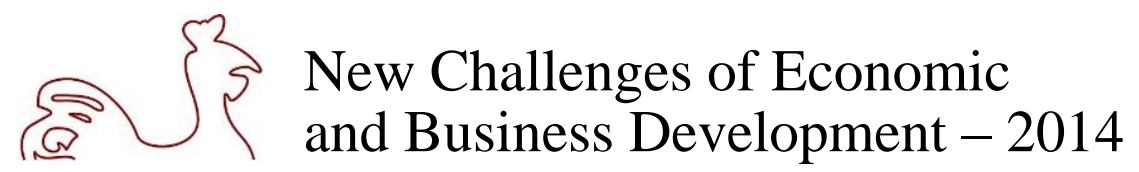

May 8 - 10, 2014, Riga, University of Latvia

\title{
ONLINE MARKETING TOOLS USEFULNESS IN MANAGING CUSTOMER PURCHASE DECISION PROCESS
}

\author{
Ronalds Skulme, University of Latvia, Latvia; \\ Valerijs Praude, University of Latvia, Latvia ${ }^{62}$
}

Key words: online marketing tools, consumer behaviour, manufacturer online marketing

JEL code: M31

\section{Introduction}

Because of the rapid development of information technology, companies systematically use online marketing tools that help influence customer purchase decision making process. Although many companies use online marketing there have been both successful and unsuccessful cases of online marketing (Rubaiyet Hasan Khan, 2013). In the past years many new online marketing tools have been brought to the online marketing tool market and have provided advertisers with new advertising and online marketing data analysis methods and possibilities. Popular websites, for example Foursquare, LinkedIn, Ask.fm, and their online marketing tools provide new marketing possibilities to businesses.

Technological advances have provided customers the possibility to gather large amount of information from lots of sources before making a purchase decision. It is possible by means of search engines, social networks and other online marketing tools. This has influenced the way how customers search for information about products. Search engine marketing has become the most important online marketing instrument nowadays (Jonathan Barnard, 2013). Several researchers have researched the impact of online consumer reviews on the purchasing decision making process (Kem Z. K. Zhang, Christy M. K. Cheung, Matthew K. O. Lee 2013).

Technology development, rapid growth of online marketing tool offerings, marketing tool diversity, and online marketing tool growing influence on purchase decision making process request to conduct systematic researches on how online marketing tools influence the purchase decision process and which online marketing tools are more useful to use to influence certain purchase decision process stages.

The aim of the study was to determine which online marketing tools available to manufacturers are more useful to use to influence the customer purchase decision making process and which tools are less useful. This is a pilot research, there for one of the research goals was to gather enough information about the online marketing tools to determine if there is any further research required.

To reach the aim of the study, the following tasks were set: research theoretical material about customer purchase decision process; research theoretical material about internet marketing tools and their categorization; conduct expert survey; conduct expert interview; conduct customer survey; based on the collected information decide on which online marketing tools are more useful to use to influence certain consumer purchase decision process, draw conclusions and make proposals on how to improve the conducted research.

\footnotetext{
${ }^{62}$ Corresponding author - e-mail address: valerijs.praude@lu.lv, phone number: +371 67034611
} 


\section{2 $\{$ New Challenges of Economic and Business Development - 2014}

May 8 - 10, 2014, Riga, University of Latvia

\section{Methods and results}

To achieve the aim of the paper the authors used quantitative and qualitative research methods. The following research methods were used: systematic and comparative literature analysis, surveying and focus group interviews.

The authors compared different scientific literature sources about online marketing tool classification and customer purchase decision making process. Based on the researched literature authors drew conclusions and proposed a new online marketing tool classification. Collected information was used as the basis for survey and focus group interview questions. The interview participants and survey respondents had theoretical and practical knowledge in marketing.

The expert surveying as a quantitative research method was used to obtain data about which online marketing tools are more useful to use to influence business purchase decision making process. Each research question was related to different purchase decision process stage.

Customer surveying was used to get data from customers, how they think which online marketing influence them the most in each stage when making a purchase decision.

Focus group interviews were used to gather additional information about the online marketing tools and their influence on the business purchase decision making process. The respondents had to explain why they gave following answers to the research question. Based on the answers of the respondents, authors asked additional questions. The questions were conducted so that authors could gather more relevant information to the research that using quantitative research method surveying could be missed.

\section{Conclusions}

The research paper has both scientific and practical importance. In this research a new online marketing tool categorization was proposed. The research shows which online marketing tools manufacturers should use to influence curtain customer purchase decision process stages from the point of view of business and customers.

This research can be used as a guide developing an integrated marketing communication strategy.

Based on the results of this research the authors came to the following conclusions: all online marketing tools can be used to influence customer purchase decision making process; some of the online marketing tools are more useful for certain business purchase decision making processes and activities. From business perspective, in order to influence all customer purchase decision process stages, is more useful to use social media marketing, affiliate marketing and mobile marketing tools.

This research will help the authors conduct more in-depth researches about the online marketing tools and their effects on consumer purchase decision process.

\section{Bibliography}

J. Barnard., 2013. Executive summary: Advertising Expenditure Forecasts June 2013. [Online] Available at: http://www.zenithoptimedia.com/wp-content/uploads/2013/06/Adspend-forecasts-June-2013-execu tive-summary.pdf.

Kem Z. K. Zhang, Christy M. K. Cheung, Matthew K. O. Lee. Examining the moderating effect of inconsistent reviews and its gender differences on consumers' online shopping decision. International Journal of Information Management 34, 2014, pp. 89-98.

Rubaiyet Hasan Khan, 2013. Marketing Education Online: A Case study of New Zealand Higher Education Institutions. Procedia - Social and Behavioral Sciences, Volume 103, 26 November 2013, pp. 637-646. 


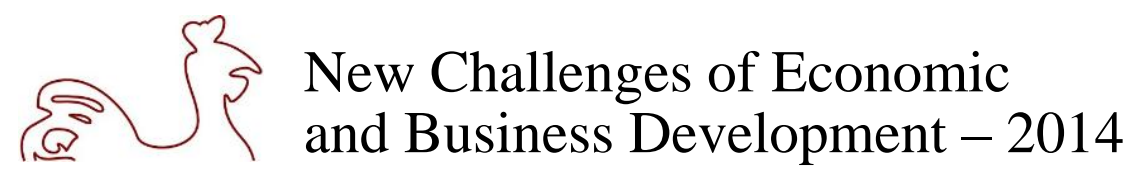

May 8 - 10, 2014, Riga, University of Latvia

\title{
PERFORMANCE EXPECTATIONS OF ENTREPRENEUR'S IN BUSINESS START \\ (Comparative Studies in Latvia in Comparison with Canada, USA, Mexico)
}

\author{
Biruta Sloka, University of Latvia, Latvia ${ }^{63}$; \\ Valdis Avotiņš, Ventspils University College, Latvia; \\ Ināra Kantāne, University of Latvia, Latvia; \\ Elita Jermolajeva, Daugavpils University, Latvia; \\ Natālija Jarohnoviča, Ventspils University College, Latvia; \\ Anete Brauča, Ventspils University College, Latvia
}

Key words: business start, entrepreneurs, performance expectations

JEL codes: M13, M38

\section{Introduction}

Business start is important issue from government policy side as well as it has interests of academic researchers worldwide. Researcher attention is paid on decision to start or not to start business (Townsend, et al, 2010), on issues on business takeover or new venture start (Parker, et al, 2012), different approaches in business start - up are analysed (Chwolka and Raith, 2012), there are made evaluations of different research conducted in this area during half a decade (Lambert and Davidson, 2013), made comparisons and cross - country investigations (Clerq, et al, 2012), made different kinds of forecasts (Cassar, 2014). Researchers are interested in performance expectations of entrepreneurs in business start: which driving forces are most important, do they differ in different countries, by age groups, by education level obtained to examine intrinsic and extrinsic motives in different contexts. Research aim is to make comparisons of performance expectations of entrepreneurs willing to start business in comparison with entrepreneurs in Canada, USA and Mexico. The results of researchers could be used for public administrators and politicians for preparation of suggestions for decision making.

\section{Methods and results}

Research methods used: scientific literature studies, survey of starting entrepreneurs in the business start phase in Latvia (survey was conducted in October - December, 2013) which is comparable with survey conducted in Canada, USA and Mexico, results are compared with survey results in Canada, USA and Mexico. In survey for most of questions evaluation scale $1-5$ is applied. The same methodology is used as in countries listed. For data processing descriptive statistical indicators, factor analysis and variance analysis are applied. Main findings of the paper are that in general the motivation factors in different countries are alike, but for Latvia entrepreneurs willing to start their business most important factors are: make own decisions, increase income, have fun, maintain personal freedom and among the less important factors are: provide jobs for family, gain public recognition.

It is checked - only one motivation factor - be own boss, differed statistically significant depending on entrepreneur's education level in Latvia; it was performed by help of analysis of variance. The mean

${ }^{63}$ Corresponding author - e-mail address: Biruta.Sloka@lu.lv, phone number: + 37129244966

122 Biruta Sloka, Valdis Avotiṇš, Ināra Kantāne, Elita Jermolajeva, Natālija Jarohnoviča, Anete Brauča 


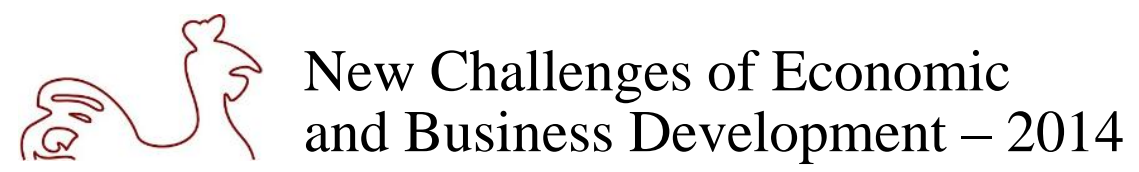

May 8 - 10, 2014, Riga, University of Latvia

difference was significant $(p<0.05)$ between entrepreneur's evaluations with different education levels: high school/vocational school and college or university degree. Different average evaluations (arithmetic mean, mode and median) are included in figure 1. The results confirms that higher evaluations of willingness to be own boss are for starting entrepreneurs with higher education (university education or college education).

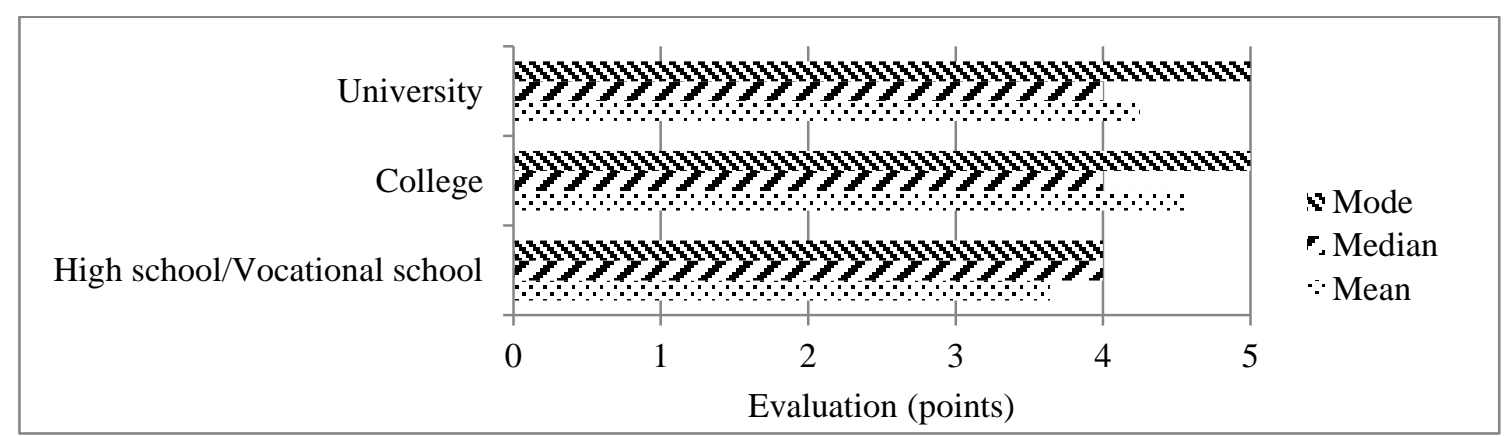

Source: authors calculations based on starting entrepreneurs survey conducted in 2013 October - 2013 December $(n=195)$, evaluation scale $1-5$, where 1 - not significant. 5 - very significant.

Fig. 1. Entrepreneurs average assessments of the significance of motivation factor be as own boss, in business start in Latvia in 2013

For starting entrepreneurs in Latvia most important factor is Personal satisfaction, than Financial returns - profits and sales having almost the same values as other factors included in the research, surprisingly lower than in other countries was evaluated factor Money drawn from the business.

\section{Conclusions}

Main findings of the paper are that in general the motivation factors in different countries are alike, but for Latvia entrepreneurs willing to start their business most important factors are: have fun, make own decisions, increase income, maintain personal freedom and among the less important factors are: gain public recognition; provide jobs for family.

\section{Bibliography}

Cassar, G., 2014. Industry and Startup Experience on Entrepreneur Forecast Performance in New Firms. Journal of Business Venturing, 29, pp. 137-157.

Chwoka, A., Raith, M.G., 2012. The Value of Business Planning Before Start - up - A Decision Theoretical Perspective. Journal of Business Venturing, 27, pp. 385-399.

De Clercq, D., Meuleman, M., Wright, M. 2012. A Cross - Country Investigation of Micro - Angel Investment Activity: The Roles of New Business Opportunities and Institutions. International Business Review, 21, pp. 117-129.

Lambert, S.C., Davidson, R.A., 2013. Applications of Business Model in Studies of Enterprise Success, Innovation and Classification: An Analysis of Empirical research from 1996 to 2010. European Management Journal, 31, pp. 668-681.

Parker, S.C., van Praag, C.M., 2012. The Entrepreneur's Mode of Entry: Business Takeover or New Venture Start? Journal of Business Venturing, 27, pp. 31-46.

Townsend, D.M., Busenitz, L.W., Arthurs, J.D., 2010. To Start or not to Start: Outcome and Ability Expectations in the Decision to Start a New Venture. Journal of Business Venturing, 25, pp. 192-202. 


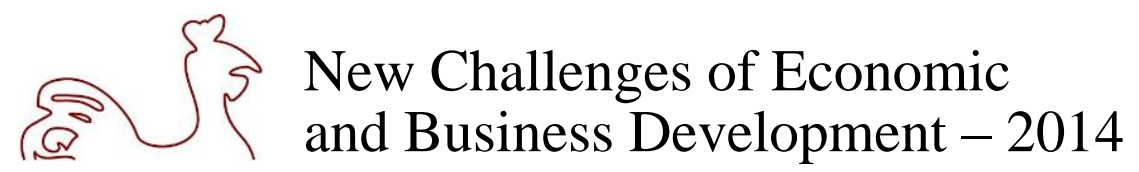

May 8 - 10, 2014, Riga, University of Latvia

\title{
ACCEPTANCE THROUGH WILLINGNESS AND READINESS IN CHANGE PROJECTS
}

\author{
Gordana Spejic, University of Latvia, Latvia ${ }^{64}$ \\ Key words: change management, change leadership, acceptance, change preparation
}

JEL codes: M12, M53

\section{Introduction}

Change initiatives and complex implementations in companies generally experience a high failure rate. The reason lies to a high extent in the resistance of the change agents. Lack of motivation, knowledge and qualification, uncertainty, overburdening and fear dominate their attitude and behaviour. Overcoming this opposition needs an understanding of the skill- and will-barriers as the main factors that lead to resistance in change projects and also requires adequate tools to successfully overcome them.

Complexity, dynamics and uncertainty still dominate the corporate world, the pace of change steadily increases and the pressure on the companies to change continuously grows. The cycles of change are getting shorter, but the prediction of necessary changes is difficult, and the extent of important measures to adapt is in the same time getting greater and deeper. Organisational change is therefore no longer an exceptional situation. It is widely accepted that companies nowadays are not only forced to change, but more, they are faced with the existential necessity to review their structures and processes constantly and flexibly adapt to the dynamic environment. However, companies have great difficulties to adapt adequately to these fast, frequent and intensive needs for change, to induce change independently and to mobilize their employees accordingly. Here, the ability to organisational change is crucial for their survival. Nevertheless it is known that in practice many change projects are marked of a high failure rate. Obviously, the knowledge about the right approach to organisational change and its processes is still incomplete or not yet exhausted.

This analysis focuses on the leaders and managers in change projects, the so called change agents, as they represent the key actors. Their importance lies in the fact that they co-decide between success and failure. Yet, this important involved party shows a lack of willingness and readiness to actively take over this role. The reasons are often amongst impending loss of power and control, stress, work overload, limited resources, high risk of failure, career risk, scepticism about the need for change and the way change has to be conducted. Beyond the lack of motivation, they also show a lack of skills, often due to little experience with change situations. Especially decisions and actions in change situations require particular skills and competencies of the acting change managers, e.g. the ability to convince and to clear communication in connection with a consequent goal orientation, sensitivity and empathy.

Based on the current needs of the corporate practice, the objective of this research is to develop a change management concept which aims to establish willingness and readiness of the involved to act and adapt in change processes. To answer the question, how change agents have to be prepared, in order to successfully manage organisational change projects and thus contribute to the overall increase of the company's change performance, the following goals are tracked: a profound understanding of change management and change leadership, the development of a new understanding of change agents, the elaboration of the roles, tasks and requirements in change projects and an analysis and description of the relevant aspects in terms of motivation, qualification and communication.

${ }^{64}$ Corresponding author - e-mail: gordana.spejic@gmx.de 


\section{$\left\{\begin{array}{l}3 \\ 5\end{array}\right.$ New Challenges of Economic and Business Development - 2014}

May 8 - 10, 2014, Riga, University of Latvia

\section{Methods and results}

At its core, the work deals with the question how to achieve commitment of the relevant actors, what motivates them to support change projects, to block them or to leave the company, which qualification is needed and what kind of communication is appropriate. This is especially important, since the challenge to reach commitment and acceptance is different in a "business as unusual" change environment than in everyday's "business as usual". As the main method the review of existing organisational, business and social psychological literature and studies will be used. Literature recognises the importance and significance of change readiness and change willingness as core aspects of commitment and acceptance and thus changes excellence. The first findings highlight the outstanding importance of commitment in change projects, because actors will only do what they are ready, willing and able to do. Commitment is seen as one of the key factors for organizational survival and growth and involves the willingness of employees to exert higher efforts on behalf of the company. In order to reach this, companies must in turn show their commitment by providing supportive work conditions and environments which is also a result of the culture. In order to face the challenge of motivation of the actors to carry out important and proactive roles, a fit between the capabilities and the tasks must be established.

\section{Conclusions}

The current analysis intends to give an overview of the first findings of acceptance based on the current literature. There are some agreements with previously published work, but the findings are not exhausted yet. The successful management of change projects emphasizing on the commitment and acceptance of the initiatives by the change agents is crucial for any company to succeed in the highly competitive and changing business environment. There are a number of existing and accepted change management theories, but as a first result, there is still a lack in the theories of how to achieve willingness and readiness by the relevant actors and thus how to promote ownership of the change project.

\section{Bibliography}

Almeida C. \& Matos, J. \& Cunha, M., 2003. The Manager as Change Agent. International Studies of Management \& Organization, 33(4), pp. 65-93.

Caldwell, R., 2003. Change leaders and change managers: different or complementary? Leadership \& Organization Development Journal, 24(5), pp. 285-29.

Chalofsky, N. \& Krishna, V., 2009. Meaningfulness, Commitment, and Engagement: The Intersection of a Deeper Level of Intrinsic Motivation. Advances in Developing Human Resources, 11(2), pp. 189-203.

Higgs, M. \& Rowland, D., 2005. All Changes Great and Small: Approaches to Change and its Leadership. Journal of Change Management, 5(2), pp. 121-151.

Kotter, J.P., 1995. Leading change: why transformation efforts fail. Harvard Business Review, 73(2), pp. 59-67. 


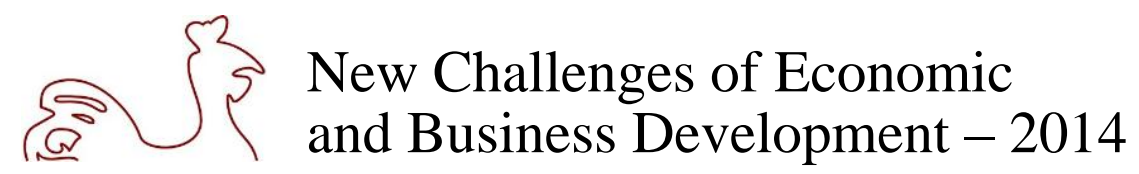

May 8 - 10, 2014, Riga, University of Latvia

\title{
CHANGES IN OIL PRICES AND GLOBAL ECONOMIC GROWTH
}

\author{
Natalia Spiridonova, Saint-Petersburg State University \\ of Economics, Russian Federation ${ }^{65}$
}

Key words: oil prices, economic growth, exchange rate, oil price elasticity, price shock

JEL code: F62

\section{Introduction}

Today among the factors affecting the growth the global economy most strongly is the price of energy. Usually it is considered that the increase in oil prices causes a decrease in economic growth. The paper shows that the impact of rising oil prices on the global economy can be both positive and negative. What does it depend? The purpose of this work is to study the impact of oil prices on economic growth in developed and developing countries, including economy of Russia, today. It is necessary to identify the factors determining the dynamics of oil prices and analyse different aspects of this impact.

\section{Methods and results}

This study uses a combination of methods of modern economic theory, the analysis of the international statistics (BP, OPEC, CGEC, oilprice.com) that apply to the study of international economic relations and the problems of global development. The main research methods are functional, comparative and systematic analyses.

In conditions of globalization of world economy oil is still the most important energy resource, the most important commodity in world trade. Moreover, economic and political significance of oil only increased in the last time. Oil demand will continue to grow steadily in the next 20 years, therefore oil will retain its leading position in the global energy balance until 2020 (its share decreased slightly). Global demand for liquid fuels (oil, biofuels, etc.) will provide by rapidly developing non-OECD countries, first of all - China (8 million bbl/d), India (3.5) and the Middle States East (4). (BP 2012)

Change of prices on the hydrocarbon markets leads to a redistribution of resources, financial and commodity flows in the global economy. The existence of the relationship between oil prices and macroeconomic indicators of the world economy recognised by the majority of analysts. For example, J. Hamilton showed that 10 of the last 11 recessions were associated with a sharp rise of oil prices, with price shocks. (Hamilton 2009)

The growth of oil prices reduces the real GDP growth directly affecting the consumption of petroleum products. In most countries the consumption expenditure in real terms is the largest component of real GDP. Oil prices also influence through indirect ways: higher costs, inflation in importing countries, the change in value of the shares of oil companies, etc. We must also consider that the strength of influence depends on various factors such as: the value of oil price changes, the importance of oil to the economy, long-term price sensitivity in world oil demand, the adoption rate of oil consumption to changes in the price, currency fluctuations, inflation and other as well as the law of supply and demand, rent nature pricing, instability in oil-exporting countries. For example, the oil price is rising with the weakening of

${ }^{65}$ Corresponding author - e-mail address: sp_nv@ mail.ru, phone number: +7 9119416999 


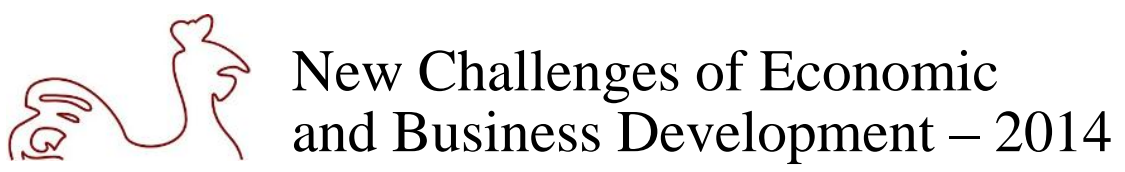

May 8 - 10, 2014, Riga, University of Latvia

the dollar (compensating losses from devaluation for exporters), whereas the strengthening dollar declines. (Schulmeister, 2013)

Stable but the opposite trend can be found in the relationship of global economic growth and changes in oil prices in 1996-2007. Economic growth has been consistently above 4.4\%, inflation - low (on average $3.7 \%$ per year), oil prices raised an average of $18.5 \%$ per year while demand for oil grew too (despite a significant decrease of $3.9 \%$ in 2004 to $1.1 \%$ in 2007). Under certain conditions, jump in oil prices still retain the ability to affect economic growth negatively. Inverse relationship between rising oil prices and economic growth returned in 2008-2009.

On the basis of studies of the effect of high oil prices and the effects of the oil shock (eg, an increase of $25 \%$ ) on the economies of many developed countries in the 1970s (and in particular the U.S. (Rasmussen T., Roitman A., 2011)), we can conclude that the global economy (especially the developed countries) could adapt to the volatility of the oil market. In 2002-2007, oil prices increased significantly, but economic growth was seen in most developed countries. High oil prices causes a reduction in economic growth, especially in the oil-importing countries with a ratio of oil imports to GDP of more than $5 \%$, as well as in developing countries.

The fact that the negative impacts of high oil prices on developed countries were generally quite small does not mean that it is the impact can be ignored. Some countries have a huge negative impact of high oil prices. Efforts to reduce dependence on oil can help reduce the impact of any price shocks and, therefore, reduce costs of macroeconomic instability. Economic growth in Russia is substantially dependent on revenues from energy exports, including oil. A large proportion of Russian TEK in the economy, the dependence of its revenues from world oil prices and prices of petroleum products leads to the fact that the financial results of the industry and the country's budget is fully dependent on external factors.

\section{Conclusions}

Based on the study on the impact of high oil prices on global economic growth, we can conclude that the global economy, especially the developed countries, could adapt to the volatility of the oil market. High oil prices cause a reduction in economic growth, especially in the oil-importing countries and in developing countries. Do not underestimate the huge negative impact of high oil prices on economic development. Efforts to reduce dependence on oil can help reduce the impact of other price shocks and, therefore, reduce the costs caused by macroeconomic instability. Due to the high dependence of Russian economy on energy prices comprehensive efforts are needed to ensure macroeconomic stability and promote the development of innovative industries.

\section{Bibliography}

BP, Statistical Review of World Energy, June 2012. [Online] Available at: http://www.bp.com/ statisticalreview [Accessed 25 June 2013].

Hamilton, James D., 2009. Understanding Crude Oil Prics, Energy Journal, 30, pp. 179-206.

Schulmeister Stephan, 2013. A systemic problem needs a systemic solution, The European Monetary Fund, Revue de l'OFCE, 2013/1, No. 127, pp. 389-424. [Online] Available at: http://www.cairn.info/ revue-de-1-ofce-2013-1-page-389.htm [Accessed 30 November 2013].

Rasmussen T., Roitman A., 2011. Oil Shocks in a Global Perspective: Are they Really that Bad?, IMF Working Papers 11/194. [Online] Available at: http://www.imf.org/external/pubs/ft/wp/2011/wp 11194.pdf [Accessed 20 February2013]. 


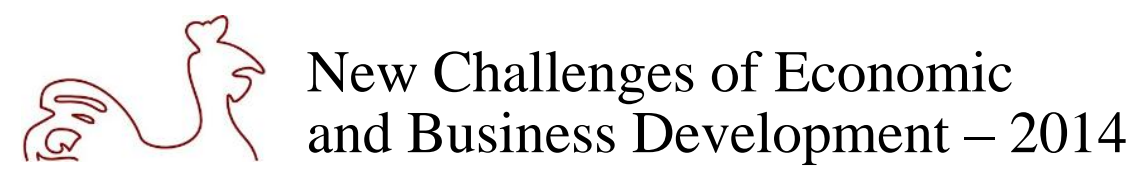

May 8 - 10, 2014, Riga, University of Latvia

\title{
EXPORT POTENTIAL DETERMINATION OF HIGHER EDUCATION OF THREE UNIVERSITIES OF BALTIC STATES IN THE ASPECT OF "NEW COMPETITIVENESS"
}

\author{
Santa Sprog̣e-Rimša, University of Latvia, Latvia ${ }^{66}$
}

Key words: new competitiveness, higher education, export potential

JEL codes: I23, I25

\section{Introduction}

Taking into account demographic and economic situation in Baltic countries, topic of an article is very live as in next ten years it may result in immigration increase. In order to ensure country's competitiveness and develop national economy, Baltic States could not be considered as cheap workforce countries. Therefore higher education export has to be developed to attract educated and gifted foreign students who would have the potential to create products with high added value, which is a key point of competitiveness.

Among researchers "new competitiveness" is being analyzed, taking into consideration globalization process and increase of competition. K.Ergazakis, K.Metaxiotis, J.Psarras (Ergazakis K., Metaxiotis K., Psarras J., 2005., pp. 6) L.R.Lattimer (Lattimer R.L., 2003., pp. 1) defines it as individual's ability under process of globalization to gain maximal benefit from centralized workforce and use of new technologies. "New competitiveness" is regionally orientated, in such way ensuring knowledge transfer with the help of cluster. For it to be carried out, J.M.V.Marti, B.M.Rodriguez (Marti V.M.J., Rodriguez M.B. 2006., pp. 51) points to crucial cooperation within sector, government and universities. M.Kantola, J.Kettunen (Kantola M., Kettunen J., 2012., pp. 7) point that under the process of globalization universities must manage to find a place in the global market, therefore very important are strategic goals, which must be defined. Higher education export contributes to the economic development, and intellectual capital increase, which is significant factor to contribute to knowledge-based society. D.R.Beeman and T.W.Sharkey (Beeman R.D., Sharkey W.T. 2008., pp. 147) states another reason due to which demand of higher education grows, it is workforce substitution with technology which increases competition to job vacancies.

The purpose of an article is to define factors which affect student's choice when deciding on of specific university, study program, furthermore to examine this matter from the point of view of international student in the aspect of "new competitiveness".

Article's main task is to identify current situation in international student recruitment - author is going to develop the model of current position in the international education market, identifying the challenges in increasing exports from the point of view of three Baltic States universities (in this article author reviewed University of Latvia, Vilnius University and University of Tartu).

\section{Methods and results}

To develop article's methodological base author have used outlooks of researchers, theoreticians and practicians, foreign publications, statistical data, foreign company reports, and obtained primary data. In

${ }^{66}$ Corresponding author - e-mail address: santa.sproge@ gmail.com, phone number: +371 25980980 


\section{$\left\{\begin{array}{l}\left\{\begin{array}{l}\text { New Challenges of Economic } \\ \text { and Business Development }-2014\end{array}\right.\end{array}\right.$}

May 8 - 10, 2014, Riga, University of Latvia

article method of sub-hypothesis approval or denial is used - to examine outcome of held interviews and obtained survey results. Interview type - one-on-one interview. Administration of the University of Latvia used as experts. Survey - open questions, selection of LU faculty deans. Interview questions were composed from theoretical allegations which author viewed in the theoretical part of article. To analyze other universities operating in the Baltic region author used secondary data, annual and financial reports, yearbooks.

Basing on competitiveness factors of universities author have determined several sub-hypothesis, for whish analysis she used approval or denial principal. Initially author for every interview question stated sub-hypothesis, where later with obtained answers from research participants approved or denied or proved that hypothesis cannot be denied.

1. Sub-hypothesis: "Higher education as mass product decreases quality of studies."

2. Sub-hypothesis: "International student's choice to study at specific university and country influence country itself, offered study programs at the university and quality."

3. Sub-hypothesis: "Study programs only for international students can be considered as useful and they ensure higher quality of education."

Results from analysis of sub-hypothesis are described in the article.

\section{Conclusions}

1. Competitiveness is not based on local demand, therefore it shows that international cooperation in the field of research is crucial to ensure country's economic growth, the latter indicates the importance of necessity of higher education export, which is the base to increase competitiveness.

2. The potential of the higher education export depends on: 1) adjusted legislation, 2) international study environment, 3) international cooperation, 4) research possibilities.

3. The existence of universities in the Baltic region not only is influenced by demographic issues that noticeably decrease and is continuing to decrease numbers of potential students, but other risk factors as well: 1) risk to fail to enter EU market, 2) use of out-of-date research methods, 3) decrease of study quality level, 4) reduction of LU income, 5) diminishing prestige of profession of academics. For that reason in coming years universities in the Baltic region, with the pressure from the local and foreign higher education institutions, must manage to solve problems using internal resource.

\section{Bibliography}

Beeman R.D., Sharkey W.T. On the Edge of Hypercompetition in Higher Education: The Case of the MBA. On the Horizon, Vol. 16, Iss: 3, pp. 143-151.

Ergazakis K., Metaxiotis K., Psarras J., 2005. Exploring the World of Knowledge Management: Agreements and Disagreements in the Academic/Practitioner Community. Journal of Knowledge Management, Vol. 9 No. 2, pp. 6-18.

Hemsley-Brown J., Oplatka I., 2006. Universities in a Competitive Global Marketplace. A Systematic Review of the Literature on Higher Education Marketing. International Journal of Public Sector Management, Vol. 19, No. 4, pp. 316-338.

Kantola M., Kettunen J., 2012. Integration of Education with Research and Development and the Export of Higher Education. On the Horizon, Emerald Group Publishing Limited, Vol. 20, No. 1, pp. 7-16.

Lattimer L.R., 2003. The New Age of Competitiveness. CR, Vol. 13, No. 2, 2003, pp. 1-15.

Marti V.M.J., Rodriguez M.B., 2006. The Region's Intellectual Capital Benchmarketing Systems: Enabling Economic Growth through Evaluation. Journal of Knowledge Management, Vol. 10, No. 5, pp. 41-54. 


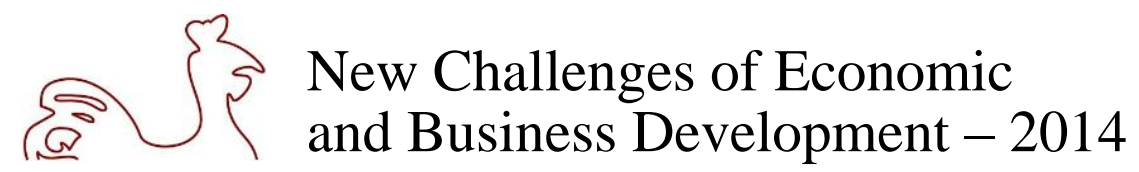

May 8 - 10, 2014, Riga, University of Latvia

\title{
BACKPACKER TOURIST SEGMENT
}

\author{
Rita Strode, University of Latvia, Latvia ${ }^{67}$
}

Key words: backpacker, tourism, co-operation

JEL codes: M30, L83

\section{Introduction}

1970s self-organized tourists were perceived as unattractive market segment. But over time picture of backpacker tourists has changed and many countries are working on the research and application of appropriate marketing activities. Although a particular group of tourists tends to spend as little as possible for the overnight stay, at the same time they want to see, to experience, to enjoy more, so a lot of money is spent on various activities, which leads to the attractiveness of this market segment.

What differs backpackers from other tourist groups is that they plan their trip differently - there is no specific travel plan. It is not, that their don't plan their trip at all, but typically, they realize ideas spontaneously, flexibly captures changes. Secondly, although backpackers tend to spend less for accommodation, they are also more inclined to see, to experience, to enjoy, so much money is spent on such activities, which gives them satisfaction for their main motivation - experience something different (P. L. Pearce, L. Murphy and E. Brymer, 2009). Thirdly, they spend more, thanks to the fact of staying longer - a longer length of stay means possibility for money consuming in a wider geographical area, which gives potential for local spatial development perspective.

There are not available statistics on a particular segment of tourists in Latvia, although there are opportunities to develop interpretations based on indicators, which have been distributed about tourists coming to stay in hostels, which is typical accommodation choice of backpacker tourists.

As the hostels is the place, where could be made offers for backpackers and thus promote their longer staying in specific country, then it is important to understand, whether they implement separate work with backpackers.

Pilot study was conducted to identify, whether backpacker tourists settle in Riga's accommodation and find out, whether there is established cooperation between the commercial enterprises to work with this client group, also the accent was made to find out, is there an interest in getting more information about backpacker tourists.

\section{Methods and results}

As for backpacker tourists are typical to stay at hostels, were made several calls to Riga hostels and telephone survey was conducted to find out:

(1) Whether their clients are backpacker tourists by providing a definition for a given trial, what was considered a backpacker tourist.

(2) To reveal, is there established cooperation with other providers of goods and services, which is important to promote the backpacker tourist satisfaction, because for them is important also the time spent, not just a place of stay, therefore it is possibility to offer more to enjoy in certain country, extending their period of stay.

(3) Whether the respondents see the value and the need to obtain information about these tourists.

${ }^{67}$ Corresponding author - e-mail address: rita.strode@lu.lv 


\section{$2\left\{\begin{array}{l}3 \\ 5\end{array}\right.$ New Challenges of Economic and Business Development - 2014}

May 8 - 10, 2014, Riga, University of Latvia

In total to 32 hostels in Riga where made calls and respondents, where invited to participate in survey. Only 18 hostels, where included in survey analysis (56\%).

The total results of this survey are reflected in the Figure 1. Respondent linked cooperation with other enterprises mainly as information placement in websites about their hostel offers, which of course contributes to the offer the intensity of the host place, but it does not offer the expression of time spending opportunities, which could promote backpackers to stay longer in specific country. The interesting fact is that, respondents, who thought, that for them would be useful to gain additional information about backpackers, also said, that they would like to increase its customer base. That could be done as attracting constantly new clients, as well as promoting their stay time.

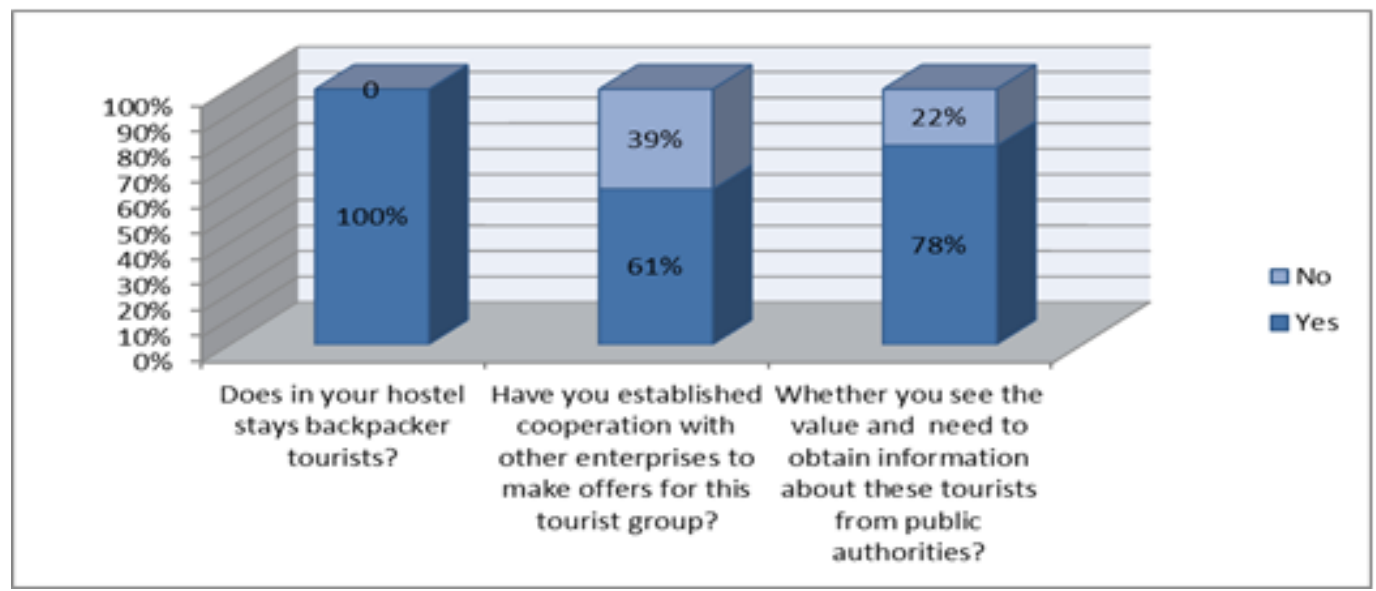

Source: author's calculations based on telephone survey results.

Fig. 1. Riga's hostel respondents given answers in conducted telephone survey 2013

Telephone survey results showed that the owners of the hostels are interested in this group of customers; there exists demand for their services that is indicated also by the fact that for some respondents work with the backpacker tourists is their principal activity.

\section{Conclusions}

Riga city is visited by backpacker tourists and there is some hostels, that focuses on work directly with this target group.

Cooperation between commercial sector representatives to make binding offers for backpackers are not very active. The most commonly co-operation from representatives of hostels was understood as information placement in websites about hostel offers. Most respondents felt, that for them would be useful to have information about the backpackers from public authorities.

Due to the fact that the backpacker implement their ideas spontaneously, flexibly captures the changes and their time of stay is longer, it is possible to promote the consumption of money on a wider geographical region. It makes potential for local spatial development perspective.

\section{Bibliography}

Pearce P., Murphy L., Brymer E., 2009. Evolution of the Backpacker Market and the Potential fo Australian Tourism. Queenland: Cooperative Research Centre for Sustainable Tourism (CRC), Griffiths University.

Rita Strode 


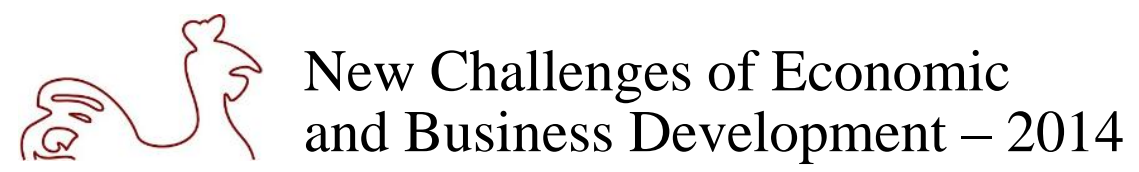

May 8 - 10, 2014, Riga, University of Latvia

\title{
STRATEGIC MANAGEMENT OF MODERN HIGHER EDUCATION INSTITUTIONS
}

\author{
Yulia Stukalina, Transport and Telecommunication Institute, Latvia ${ }^{68}$
}

Key words: higher education institution, education manager, strategic management

JEL code: M19

\section{Introduction}

The new generations of learners, technological innovations, budgetary constraints, and economic factors have given rise to the need for re-evaluating strategies employed in higher education (Kazeroony, 2012). Besides, increased competition between universities in terms of attracting and keeping students also makes education managers reconsider their strategy aimed at identifying the elements and indicators of competitive advantage. According to Watson (2000), managing strategy is supposed to be the most important thing a university does; it allows all of its main activities (teaching, research, social and economic service) to be realised. Strategic management theories provide a basis for novel approaches to strategy development in higher education institutions. Though, they do not address all pressing issues that education managers face today. Modern universities are sophisticated multilevel organizations, and the complex pattern of various contributory factors forms the background of educational management. Developing their strategy education mangers must also consider specific organisational characteristics of this sector (Tavernier, 2005). Therefore, there is the need for a thorough analysis of both traditional approaches and innovative attitudes that can be used by education managers in the context of strategy-making. The focus of this paper is on a) examining the strategic background of educational management; b) discussing some basic principles of strategy-making in a contemporary higher education institution (HEI).

\section{Methods and results}

The analysis provided in this paper is based on the academic literature review dedicated to strategymaking as a central function of modern management (Thompson \& Strickland, 1992; Kotler, 2000; Bush \& Coleman, 2000; Morden, 2007; Nag et al., 2007; Haberberg \& Rieple, 2008; Capon, 2008; Henry, 2008; Koontz \& Weihrich, 2010). Some basic principles of strategy-making in a higher education institution are discussed; it is argued that in their labours to develop and implement a number of strategies, education managers should distinguish between the corporate-level strategic goals and functional area-specific strategic goals. The goals must be set with regards to the holistic approach to management of the integrated educational environment resources. Several university-wide strategic initiatives (aimed at maintaining and enhancing academic excellence and competitive advantage) are described (Table 1). The analysis reported in the paper is also based on the author's professional experience in the area of educational management.

\footnotetext{
${ }^{68}$ Corresponding author - e-mail address: Stukalina.J@tsi.lv, phone number: +371 26714382
} 


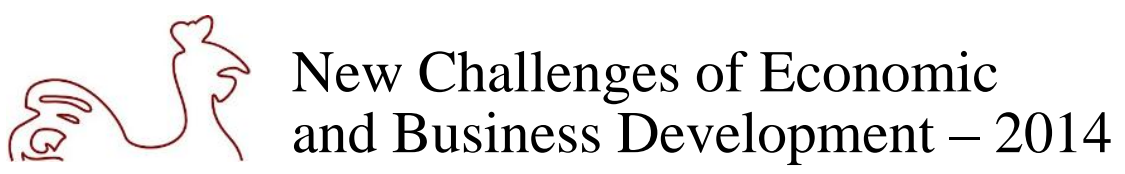

May 8 - 10, 2014, Riga, University of Latvia

Table 1

Main strategic goal areas and the corresponding supportive strategic initiatives

\begin{tabular}{|c|c|c|c|}
\hline No. & Strategic goal area & Example & Supportive strategic initiatives \\
\hline 1. & $\begin{array}{l}\text { Corporate-level } \\
\text { strategic goals } \\
\text { - External focus } \\
\text { - Internal focus }\end{array}$ & $\begin{array}{l}\text { - Maintain and enhance university overall excellence } \\
\text { - Cooperate with other HEIs and enterprises for } \\
\text { achieving academic excellence and competitive } \\
\text { advantage } \\
\text { - Cultivate a constructive educational environment } \\
\text { for achieving academic excellence and } \\
\text { competitive advantage }\end{array}$ & $\begin{array}{l}\text { - Develop an overall long-term managerial action } \\
\text { plan } \\
\text { - Create an effective coordination mechanism in } \\
\text { the frame of an overall action plan } \\
\text { - Develop a set of qualitative and quantitative } \\
\text { indicators for regular educational environment } \\
\text { evaluation }\end{array}$ \\
\hline 2. & $\begin{array}{l}\text { Functional area- } \\
\text { specific strategic goals } \\
\text { - University } \\
\text { - } \text { services/facilities } \\
\text { - } \text { Education } \\
\text { - } \text { Research } \\
\text { Academic staff }\end{array}$ & $\begin{array}{l}\text { - Develop service structures and supporting } \\
\text { infrastructure for providing sustainable } \\
\text { educational process } \\
\text { - Provide students with a high-quality education } \\
\text { - Maintain and enhance excellence in research and } \\
\text { innovation } \\
\text { - Recruit first-rate academic staff }\end{array}$ & $\begin{array}{l}\text { - Implement cost-effective university infrastructure } \\
\text { (including ICT-based infrastructure) improve- } \\
\text { ments in the frame of an overall action plan } \\
\text { - Strengthen support for research grants and } \\
\text { international collaboration } \\
\text { - Develop and implement consistent staff } \\
\text { recruitment procedures }\end{array}$ \\
\hline
\end{tabular}

Source: author's suggestions based on the academic literature review and her experience in the area of educational management.

\section{Conclusions}

The analysis performed in this paper allows the author to conclude that the implementation of strategic initiatives aimed at achieving academic excellence and competitive advantage requires the appropriate distribution (re-distribution) of the internal educational environment resources and external funds, the emphasis being put on providing tight collaboration throughout the organization for attaining necessary synergy across functional areas. The paper is written with the intention of stimulating further discussion on some basic issues related to the strategic management of modern universities in the customer-driven education context. The author hopes that whatever lessons this analysis provides will be helpful to education managers responsible for developing a strategy for a higher school improvement.

\section{Bibliography}

Bush, T. \& Coleman, M., 2000. Leadership and Strategic Management in Education. London: SAGE. Capon, C., 2008. Understanding Strategic Management. UK: Pearson Education Limited.

Haberberg, A. \& Rieple, A., 2008. Strategic Management: Theory and Application. New-York: Oxford University Press.

Henry, A., 2008. Understanding Strategic Management ( $2^{\text {nd }}$ ed.). New-York: Oxford University Press.

Kazeroony, H., 2012. The Strategic Management of Higher Education: Serving Students as Customers for Institutional Growth. USA: Business Expert Press.

Koontz, H., \& Weihrich, H., 2010. Essentials of Management: An International Perspective (8 ${ }^{\text {th }}$ ed.). New Delhi: Tata McGraw Hill.

Kotler, Ph., 2000. Marketing Management. New Jersey: Prentice Hall, Upper Saddle River.

Morden, T., 2007. Principles of Strategic Management ( $3^{\text {rd }}$ ed). UK:MPG Books Ltd.

Nag, R., Hambrick, D. C., Chen, M., J., 2007. What is Strategic Management, Really? Inductive Derivation of a Consensus Definition of the Field, Strategic Management Journal, 28(9), pp. 935-955.

Tavernier, K., 2005. Relevance of Strategic Management for Universities, Tijdschrifr voor Economie en Management, Vol. L (5) [Online] Available at: https://lirias.kuleuven.be/bitstream/123456789/ 120121/1/tem 505 tavernier.pdf [Accessed 20 December 2013].

Thompson, A., A. \& Strickland, A., J., 1992. Strategic Management: Concepts and Cases (2 ${ }^{\text {nd }}$ ed.). Homewood, Boston: IRWIN Inc.

Watson, D., 2000. Managing Srategy. Buckingham: Open University Press.

Yulia Stukalina 


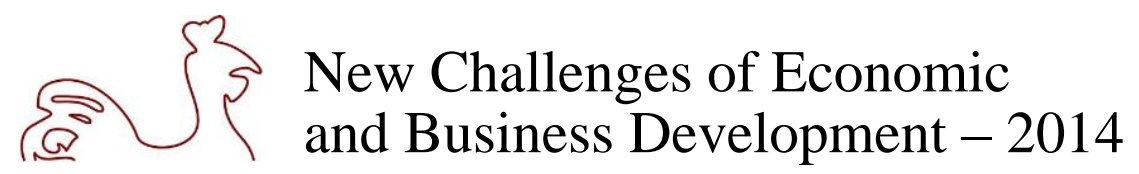

May 8 - 10, 2014, Riga, University of Latvia

\title{
QUANTITATIVE AND QUALITATIVE MEASUREMENT METHODS OF COMPANIES' MARKETING EFFICIENCY
}

\author{
Jel̦ena Šalkovska, University of Latvia, Latvia ${ }^{69}$; \\ Elīna Ogsta, University of Latvia, Latvia
}

Key words: marketing metrics, marketing efficiency, marketing effectiveness, marketing performance measurement, marketing measurement methods

JEL code: M31

\section{Extended abstract}

Though increasingly more companies recognize the importance of marketing in successful business planning and progress, yet in many cases strategic marketing planning and implementation in business environment is endangered by myopic management (Jeffrey M., 2010) which originates the demands for tangible assets and financial evaluation of marketing activities and fast Return on Investment (ROI). Common viewpoint considers marketing as costs, although these expenses should be treated as medium-term and longterm investments; this aspect shows one of the main marketing problems - economic justification. Marketers face many challenges in an increasingly complex marketplace and addressing the wide range of stakeholders prospects, customers, shareholders, partners, and vendors (Gao Y., 2010). Therefore the aim of the research was to find and point out the link between marketing investment, marketing activities, productivity gained and economic justification for stakeholders because often the traditional measures of marketing performance, such as sales and market share, are inadequate to accommodate such a wide range of issues and participants (Cook W. \& Talluri V., 2004) and deal with intangible assets that marketing brings to the business, creating deviation between companies' market value and their book value. Defining the value and management of each asset is a critical task and an important step toward the improvement of the Return on Marketing Investment (ROMI) which can and should be achieved with appropriately chosen marketing metrics and marketing efficiency measurement methods because it is then possible to evaluate whether marketing activity plays a role in driving base sales evaluation (Chain P., 2011).

\section{Introduction}

During the research authors focused on different types of marketing metrics and possibilities to measure marketing activities' efficiency - financial, salesforce, channel, product, customer, internet, media, and advertising (Farris P. et al., 2010), as well as on difficulties that are linked with usage of such metrics and methods, stemming from lack of knowledge or ability to substantiate to the management the need for such metric usage, thus eliminating the danger of myopic management that aims mostly on short-term goals. Highly significant task was to understand and point out the necessity for marketing performance evaluation process not only to ground on financial evaluation, but also on intangible and non-financial equity measurement methods. Also the task was to base the research on Latvian companies' and their practice, thus enabling a proposition of possible options for usage of measurement methods in different industries, markets, and amount of marketing investments, also to show how relevant to business and marketing strategy it can be to measure not only tangible performance indicators, but also non-financial ones. The research has

${ }^{69}$ Corresponding author - e-mail address: jelena.salkovska@lu.lv, phone number: +371 29615933 


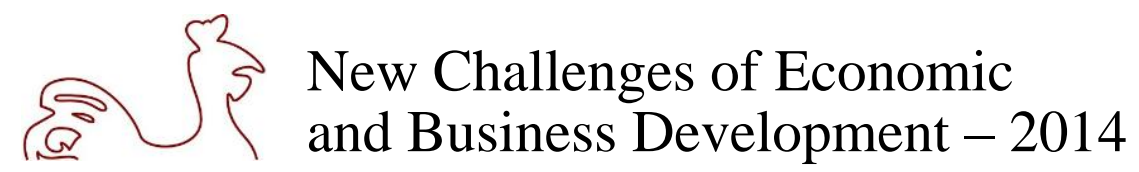

May 8 - 10, 2014, Riga, University of Latvia

practical value because it allows to evaluate current situation, to give suggestions for further research and to help marketers to gain and demonstrate marketing efficiency to stakeholders.

\section{Methods and results}

First, a review of the literature with exploratory character in regard to marketing metrics and marketing efficiency measurement methods and metrics was undertaken aimed at extracting potential ideas of a more comprehensive evaluation process for marketing activities and measuring efficiency. Second, the subject was evaluated by experts and, finally, the usage of marketing measurement methods in Latvian companies was illustrated by quantitative research, questionnaire for marketers of different firms, showing the link between marketing performance, marketing efficiency and use of marketing metrics or opposite - disuse of such measurement methods, thus the aim was to inquire into matter whether companies use such metrics at all, and if they do - what metrics are considered being most significant (e.g., financial or non-financial methods of measuring marketing efficiency). The respondent companies and organizations were selected by simple random sample method from data bases of enterprises. The online questionnaire, consisting of 20 questions and 9 collateral questions, was sent via more than 300 e-mail letters to CMOs, marketing specialists or competent managers who execute marketing function within selected companies. Their responses clarified the main marketing measurement trends in Latvian companies, and it allowed authors to draw to main conclusions and draw up proposals for various types of enterprises.

\section{Conclusions}

Based on research, which incorporated 105 Latvian SMEs, main problem is - marketing specialists have difficulties explaining and substantiating their expenses with value added to the business, many of them are not aware know how to accomplish that, and which relevant metrics could serve for this purpose. This factor leaves negative influence on marketing budget - research shows decrease in marketing budget which correlates with lack of awareness and knowledge how to justify marketing costs, thus disabling marketing specialists and marketing professionals to expand and enrich different marketing activities communication, promotion, advertising etc. Also marketing specialists in many enterprises have hard time to substantiate the usage of different marketing communication channels, e.g., social media, which should be clearly defined aspect within marketing strategy. The main conclusion drawn from this study is the existing problems - lack of knowledge, uncertainty of marketing function within firm, inability to justify marketing expenditures which could be eliminated by successful application of different and nonfinancial marketing efficiency measurement methods, tailored for each enterprise in most preferable way. Therefore authors propose optional integrated sets of marketing metrics that serve for companies in different industries and for various marketing strategic specializations.

\section{Bibliography}

Chain, P., 2011. Modelling the Real Return on Marketing Investments. Marketing NPV Journal, Vol. 7, pp. 2-7.

Cook, W. \& Talluri, V., 2004. How the Pursuit of ROMI Is Changing Marketing Management. Journal of Advertising Research, Vol. 44, Issue 3, pp. 244-254.

Farris, P., Bendle, N., Pfeifer, P. \& Reibstein, D., 2010. Marketing Metrics: 50+ Metrics Every Executive Should Master, Second Edition. New Jersey: Pearson Education, Inc.

Gao, Y., 2010. Measuring Marketing Performance: a Review and a Framework. The Marketing Review, No. (10)1, pp. 25-40.

Jeffrey, M., 2010. Data-Driven Marketing: The 15 Metrics Everyone in Marketing Should Know. New Jersey: Wiley \& Sons, Hoboken.

Jẹ̦ena Šalkovska, Elīna Ogsta 


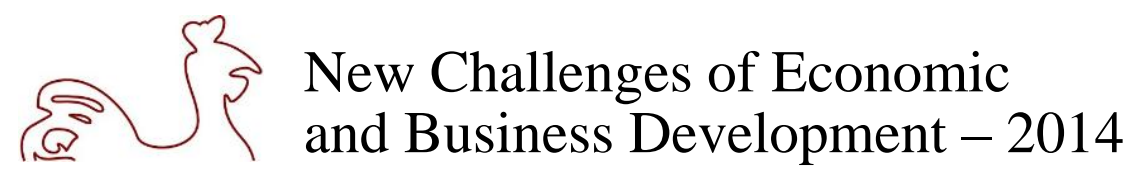

May 8 - 10, 2014, Riga, University of Latvia

\title{
SATISFACTION OF ECONOMIC NEEDS ON PUBLIC SOCIAL SOFTWARE PLATFORMS - EVIDENCE FROM THE AIRPORT INDUSTRY
}

\author{
Marion Tenge, University of Latvia, Latvia; \\ University of Applied Sciences Kufstein, Austria $^{70}$
}

Key words: Airport Industry, Social Software Platforms, Economic Need Satisfaction

JEL code: O33

\section{Introduction}

The adoption of public Social Software Platforms (SSP) by individuals and organizations is no longer in the state of infancy, but on "the verge of commoditization" (vor dem Esche \& Hennig-Thurau, 2013). With the advent of SSP the social element is step-by-step re-entering the relationship between organizations and their customers. While in the time period of industrialization marketing communication has been largely one-way in nature, SSP demand for a good knowledge of social interaction principles to encourage customer interactions for economic benefit. However, organizations are still unsure how to manage SSP. The aim of the research was to explore how the interaction with passengers on the SSP Facebook contributes to the economic need satisfaction of airport organizations. The main hypothesis is concerned with the norms of reciprocity that govern social relationships: $H_{A}$ : The interaction with passengers on SSP increases the economic need satisfaction of airport organizations, if also the sociopsychological need satisfaction of passengers increases. Research tasks included the development of a causal model consisting of structural and measurement model, the collection of data from major German airports and their passengers to test the model and the advancement of conclusions based on research results.

\section{Methods and results}

\section{Methods}

Methods of research included cross-sectional qualitative and quantitative survey research. To assess the population characteristics of major German airport organizations semi-structured expert interviews with six out of the eight major German airports were conducted. Two airports needed to be excluded from the survey due to planned airport closure and not comparable traffic segmentation. To assess the population characteristics of passengers connected to major German airport organizations on Facebook an online survey distributed via the Facebook pages of the sampled airports was deemed most appropriate. The online survey yielded 734 responses. 600 passengers fully completed the questionnaire. Quantitative data obtained from the airport und passenger survey were analysed using the methods of statistical analysis with the software package SPSS (correlation analysis, analysis of differences between groups). Construct validation for reflectively measured constructs was performed through reliability testing and confirmatory factor analysis. Construct validation for second-order formative constructs was assessed through review of inter-correlations between first-order constructs. Qualitative data obtained from the expert interviews was submitted to content analysis. Items were coded manually based on frequency of occurrence.

\footnotetext{
${ }^{70}$ Corresponding author - e-mail address: marion.tenge@gmx.net, phone number: +49 177 / 8736325
} 


\section{ล⿵冂人 $\left\{\begin{array}{l}\left\{\begin{array}{l}\text { New Challenges of Economic } \\ \text { and Business Development }-2014\end{array}\right.\end{array}\right.$}

May 8 - 10, 2014, Riga, University of Latvia

\section{Results}

The results of the correlation analysis indicated statistically significant strong positive relationships between the following variables: socio-psychological need for competence and economic need for operational process efficiency $(\mathrm{r}=+0.820, \mathrm{p}=0.046)$; socio-psychological need for meaning and economic need for operational process efficiency $(r=+0.924, p=0.008)$; socio-psychological need for relatedness and economic need for operational process efficiency $(r=+0.907, p=0.013)$. From the perspective of airport organizations operational process efficiency is currently related to the speed of passenger communication on Facebook. Mobile Facebook access further facilitates real-time communication. The study has shown that $73.3 \%$ of passengers access Facebook with their smartphones. The results of the correlation analysis suggest a link between real-time communication and the satisfaction of the human needs for competence, meaning and relatedness. Real-time communication enables passenger to satisfy their innate need for competence, as compared to traditional communication channels, passengers are able to more quickly achieve expected outcomes on SSP. The need for meaning is addressed by the airports by quickly providing information and orientation in uncertain situations. An immediate reaction of airports in uncertain situation to passenger requests also generates satisfiers for the need for relatedness, as passengers feel cared for by the airport.

Correlation analysis also indicated a statistically significant strong negative relationship between the variables: socio-psychological need for self-determination and economic need for customer satisfaction $(r=-0.822 ; p=0.045)$. The satisfaction of the need for self-determination on Facebook requires passengers to feel free to express their ideas and opinions with regard to the airport and their services. The negative correlation suggests that critical customer feedback on Facebook is not yet considered as an opportunity to improve processes, but that the public visibility of feedback is rather considered as a threat by airport organizations. Airport managers have emphasized the lack of representativeness of passenger feedback. The results of the Man-Whitney U test indicated that passengers with a higher perceived sociopsychological need satisfaction are more active on the airports' Facebook pages.

\section{Conclusions}

Airports already derive fruitful economic benefits from their Facebook activities. However, they are not yet able to fully exploit the potential of Facebook. The critical mass for passenger feedback to be representative is not yet reached. This currently restricts the utilization of Facebook, for example regarding an active involvement of passengers in innovation processes. Overall, the results of the study have supported the postulated main hypothesis. Human need satisfaction can be considered as a source of engagement motivation of passengers in an online environment. Passengers with a higher degree of sociopsychological need satisfaction are more active on the airports' Facebook pages. Only if airports are able to generate need satisfiers, they will profit from an increased passenger engagement as potential resource of economic need satisfaction. To tap the full potential of SSP, there is also the need for a more holistic approach to SSP management regarding for example its organizational linkage with complaint management processes.

\section{Bibliography}

Esche, vor dem J., \& Hennig-Thurau, T. (2013). German Social Media Consumer Report 2012/2013. Social Media Think:Lab Working Paper Series, (1), 1-45. [Online] Available at: http://www.socialmediathinklab.com/wp-content/uploads/2013/02/WWU_Social-Media-ConsumerReport 0213_Ansicht.pdf [Accessed July 03, 2013]. 


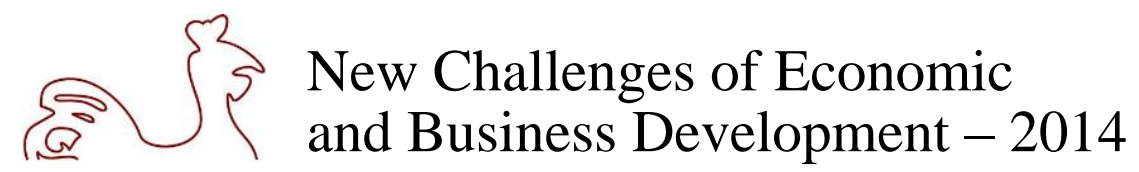

May 8 - 10, 2014, Riga, University of Latvia

\title{
THE MOST DEMANDED RATIOS OF FINANCIAL ANALYSIS AT THE ENTERPRISES OF LATVIA
}

\author{
Maria Tissen, University of Latvia, Latvia ${ }^{71}$
}

Key words: ratios of financial analysis, methods, accounting history

JEL code: L53, M41

\section{Introduction}

A scientific literature on financial analysis nowadays offers a lot of ratios for enterprise analysis, where each author suggests his own grouping and interpretations of financial ratios while using absolute or average value of components in the calculation of ratios. Thereby, a user of financial analysis might have difficulties in selection and in performing a correct calculation of financial ratios.

The aim of the paper is to identify the most demanded ratios of financial analysis at the enterprises in Latvia and to analyse them.

\section{Methods and results}

Also the leading researchers of the financial analysis are offering their grouping of financial ratios, the author of the publication has chosen them for the basis of her research, namely: Kovalev V.V., Dybal S.V., Rishar Zh., Girou G., Shermet A.D., Negashev E.V., Bernstein L.A., Helfert E.A., Higgins R.C., Pelepy K.G. Besides this, there is a grouping of financial analysis ratios, offered by the examination program of CFA (Chartered Financial Analyst)/

In the scientific literature, there are various options for grouping ratios of financial analysis, such as, The practical part of the research is based on a survey that was conducted by the author of the paper in 2013 on large and medium enterprises of leading areas of entrepreneurial activity. To determine the leading fields of activity in Latvia, the author has used the data of Central Statistical Bureau of Latvia and the data on GDP. 1860 enterprises of Latvia from six leading fields of activity (production, construction, agriculture, services, trade, transport and storage services) took part in the survey. Research questionnaire was primarily intended for the company executives and financial managers.

In the research process, the author revealed that the methods of the financial analysis scientists are divided into two points of view. One suggests using an absolute meaning of formulas components in the calculation of financial ratio; the other group as its bases takes the average value of components.

In this research the author is using quantitative and qualitative methods of economics, such as mathematical and statistical methods, the graphical method, the logically - constructive methods have been applied, and survey.

The author of this article states that the most correct is the calculation of ratio of financial analysis, using average component values. This is due to the fact that the value of ratios, calculated on different points of time, can be very different from each other due to several reasons (seasonality in sales, the amount of working capital; changes in the amount of capital, including debt capital; changes in the size of fixed assets etc.). In this regard, it is possible to make the right point of view on the state of an enterprise only by using ratios that are characterizing an enterprise on average over any selected period with the removal of such individual differences between different points of time.

${ }^{71}$ Corresponding author - e-mail address: maria@katiss.lv, phone number: +371 29452777 


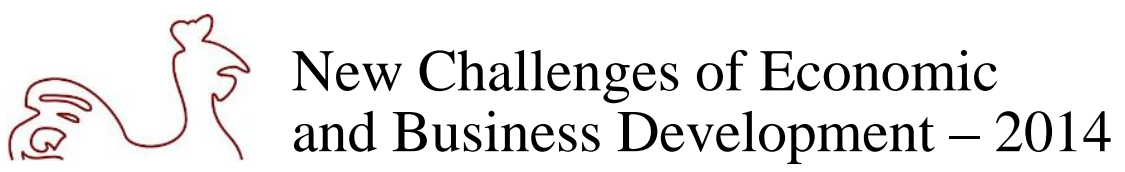

May 8 - 10, 2014, Riga, University of Latvia

Table 1

Appliance of an absolute and an average value of formula components in the calculation of financial analysis ratios by different authors

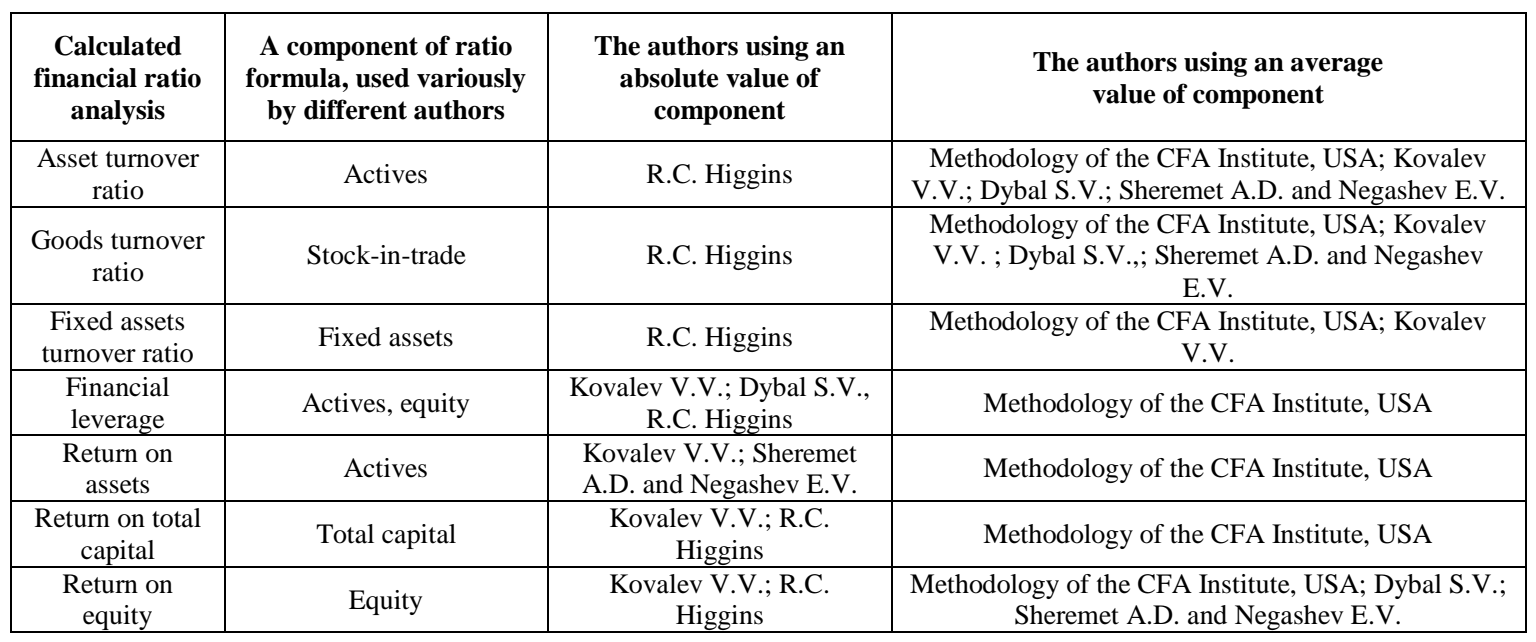

Source: author's research based on (CFA Kaplan Schweser 2010), (Higgins R.C. 2001), (Ковалев B.B. 2006), (Шеремед А.Д. 2012).

\section{Conclusions}

According to the survey on medium and large enterprises of Latvia, one can conclude that the financial analysis is not used by the enterprises in full measure, because the leaders do not always believe in reliability of ratios or are not fully aware of the methods in the use of financial ratios.

Following the survey of the author of this article, the most demanded ratio of financial analysis was revealed. It was analysed and discussed by the author in this article from the historical side and from various calculation methods, presented by the leading experts of financial analysis: a) activity ratios; b) liquidity ratios; c) solvency ratios; d) profitability ratios e) valuation ratios.

Analysis of the history of the emergence and maintenance of the main financial analysis ratios (activity ratios, liquidity ratios, solvency ratios, profitability ratios, valuation ratios) revealed an interesting theoretical problem: some researchers for calculation of financial ratio analysis are using an absolute value of formula components, and others the average value of components. The author of this article has substantiated the point of view, according to which the use of the average values of components is more accurate.

In later works the author plans to modify the most demanded financial ratio analysis and, for more accurate data, to supplement the analysis with procedures of due diligence.

\section{Bibliography}

CFA Level 1 Schweser Study Notes 2010. Book 3 2009. Financial reporting and analysis. Kaplan, Inc. Higgins R.C., 2001. Analysis for Financial Management. Sixth Edition, Irwin McGraw-Hill.

Ковалев В.В., 2006. Финансовый анализ: методы и процедуры. - М.: Финансы и статистика.

Шеремет А.Д., Негашев Е.В., 2012. Методика финансового анализа деятельности коммерческих организачий. М: ИНФРА-М. 


\title{
$\left\{\begin{array}{l}3 \\ 5\end{array}\right.$ New Challenges of Economic and Business Development - 2014
}

May 8 - 10, 2014, Riga, University of Latvia

\section{PREVENTION ET LUTTE CONTRE LE TRAVAIL NON DECLARE, UNE PROVOCATION GLOBALE DANS U.E.}

\author{
Dan Ţop, Université Valahia de Târgovişte, Roumanie ${ }^{72}$
}

Key words: travail non déclaré; emplois; marché du travail; travail dissimulée; inspection du travail

JEL code: K 310

Dans L'Union Européenne le travail non déclaré définie comme toute activité rémunérée qui est légale en ce qui concerne leur nature mais non déclarée aux pouvoirs publics, en tenant compte des différences entre les systèmes réglementaires des États membres, est un phénomène complexe qui se produit en raison d'un certain nombre de facteurs, tels que la fiscalité excessive du travail et d'autres une augmentation des coûts de main-d'œuvre, les procédures administratives très complexes et coûteuses, le manque de confiance dans le gouvernement, le manque de mécanismes de contrôle, le manque de stabilité du marché du travail de l'emploi et des niveaux élevés de l'exclusion sociale et la pauvreté.

Causes qui génèrent des situations de travail sans papiers ou non déclaré sont déterminés principalement par les avantages financiers fournis par l'employeur, mais souvent la personne qui travaille est d'accord avec cette situation, le désir de compléter leur revenu. En général, le but principal de l'utilisation de cette pratique consiste à éviter le paiement des impôts et cotisations sociales.

Le travail non déclaré a des incidences budgétaires importantes, en raison de baisse des recettes fiscales et des cotisations de sécurité sociale. Elle a un impact négatif sur l'emploi, la productivité et les normes travailler sur le développement des compétences et l'apprentissage continue. Travail non déclaré aussi ne fournit pas une base solide pour le bénéfice des droits à pension et l'accès aux soins de santé.

L'une des formes les plus courantes de fraude reste, de cacher le temps dont le travail est effectué. Par exemple, existe un contrat en temps partiel mais en réalité l'activité est de huit heures par jour. Est un forme de travail dissimulée. Pendant les périodes de crise économique, ce phénomène est exacerbé: employeurs et les employés sont guidés par d'intéresse immédiat et significatif violation des règles du droit du travail. Le travail dissimulée a des effets négatifs à court terme et surtout à long terme, en visant l'employé, l'employeur, et le budget de l'Etat, car il y a une relation d'interdépendance entre les cotisations et le paiement des taxes et des droits d'accès de la sécurité sociale et autres mesures de protection sociale.

Bien que les objectifs fixés par l'inspection du travail se trouvent dans toutes les formes qui luttent contre de travail illégal, il n'y a pas d'orientation commune pour la lutte contre le travail partiellement caché. Toutefois manquent des mesures pour la responsabilité de l'employé dans la lutte contre l'emploi déguisé.

Prévention et lutte contre le travail non déclaré ou dissimulé proviennent principalement dans les États membres mais il est nécessaire une action au niveau de l'UE de promouvoir la coopération entre les autorités nationales et à faciliter l'échange des meilleures pratiques pourrait être un soutien considérable, renforcer les efforts déployés par les autorités pour prévenir, repérer et sanctionner le travail non déclaré et en même temps le travail dissimulé.

Le but de cette étude est d'identifier des solutions qui peuvent lutter contre ce fléau, à la fois économique et juridique, de stimuler la croissance de la responsabilité des employés et des employeurs, et pas moins la création d'un cadre approprié pour la coopération dans le domaine entre les États membres d'Union Européenne.

${ }^{72}$ Corresponding author - e-mail address: top.dan@gmail.com, phone number: +040 722723340 


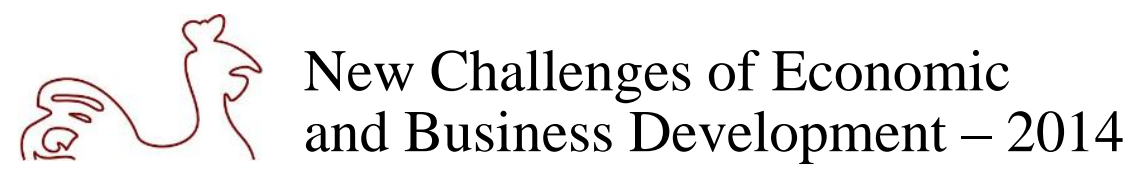

May 8 - 10, 2014, Riga, University of Latvia

\title{
CUSTOMER MOTIVES TO PARTICIPATE AS PRESUMPTION FOR SERVICE CO-CREATION
}

\author{
Jurate Valuckiene, Šiauliai University, Lithuania ${ }^{73}$; \\ Jurgita Bersenaite, Šiauliai University, Lithuania; \\ Rigita Tijunaitiene, Šiauliai University, Lithuania
}

Key words: co-creation, motives, customer participation

JEL code: M31

\section{Introduction}

Service co-creation is unique experiences of customer and service providers that open up new sources of competitive advantage for companies. The underlying logic of today's value argues that value is not embedded in an organizations output but defined by and co-created with the customers (Prahalad \& Ramaswamy, 2004; Vargo \& Lusch, 2008; Ngo \& O’Cass, 2013). Identification of motives that encourage customers to participate in co-creation enable the company to predict customer preferences, manage customer participation, help customers get involved in the process of value creation purposefully (Rodie \& Kleine, 2000; Grissemann \& Stokburger-Sauer, 2012). The research raises problematic questions: what motives of customer participation in service co-creation are identified? What are the roles of customer participation in service co-creation? What structure of motives is revealed by customer experiences? The aim of research is to identify customer motives to participate as a presumption for service co-creation. The following objectives were solved: 1) potential motives of customer participation in co-creation were identified; 2) types of customer roles explaining customers' motivation to participate in co-creation were characterised; 3) based on empirical results, the structure of customer perceived participation motives in co-creation was identified. Research methods: the analysis of literature; customer opinion survey with open-ended questions; content analysis.

\section{Methods and results}

In the first and the second pats of the research the analysis of scientific literature was used. The authors of this article refer to the conceptual attitude that a motive is a multicomponent differentiated case of action arising from personality level, determined by the human inside, but also depended on external stimuli. There are no universal motives that equally encourage customer to participate in service co-creation. The more motives the company can respond, the more attractive and more persuasive proposal for co-creation will be. The types of customer roles are and their equivalents for service proposals explaining the reasons of internal customer motivation to participate in co-creation (Chan et al., 2010 etc.).

The third part of the research covers the empirical results. The empirical research to identify the customer perceived participation benefits and costs was done in Lithuania from March $1^{\text {st }}$ to April $19^{\text {th }}$, 2013. The research involved 1631 respondents. Participants of the research reflect their own experiences and talk about participation mostly as a situation which is managed by the service provider. The motives of participation arrange from economic motives (e.g. financial rewards) to altruistic ones (e.g. desire to contribute). Customers participate for their recognition, self-expression, creating and development the

\footnotetext{
${ }^{73}$ Corresponding author - e-mail address: j.valuckiene@gmail.com, phone number: +370 41595888
} 


\section{$\left\{\begin{array}{l}3 \\ 5\end{array}\right.$ New Challenges of Economic and Business Development - 2014}

May 8 - 10, 2014, Riga, University of Latvia

relationship with customer providers. All the motives are related to customer perceived dimensions of service quality, price, and emotion directly. The content analysis results confirm that the defined participation motives are more individual than common and are also directly related to assumed role by a person in service delivery process.

\section{Conclusions}

1. The customer motives to participate in service co-creation are sorted into intrinsic and extrinsic ones. Hence participation motives are linked to intrinsic and extrinsic, tangible and intangible, social, psychological and economic reasons to perform an active role in service. In summary it can be claimed that motivation to participate in co-creation can be explained by different customer roles that express internal customer reasons. The scientific literature confirms that there is the connection between the motives and roles of participation in service co-creation. The typology of customer participation in co-creation consists of different types of customer roles, especially oriented to the outer, social interaction and benefit others.

2. The personalized opinions of customers reveal that motives of participation in co-creation are related to customer perceived dimensions of service quality, price, and emotion. The participation motives indicated by respondents of the research are only individual and related to accepted role by a person in service delivery process.

3. It can be argued that in order to customer participation as a presumption for service co-creation each company needs to influence on its customers purposefully according to their individually perceived motives, by encouraging to assume roles that enhance their conscious participation in co-creation as a presumption to increase company competitiveness. However it is relevant for a company to change the opinion of the participating customer, to encourage his activity and wish to improve service quality not only for themselves, but for others, too.

\section{Bibliography}

Chan, K. W., Yim, C. K. B., Lam, S. S. K., 2010. Is Customer Participation in Value Creation a DoubleEdged Sword? Evidence from Professional Financial Services across Cultures. Journal of Marketing, 74, pp. 48-64.

Grissemann, U. S. \& Stokburger-Sauer, N. E., 2012. Customer co-creation of travel services: The role of company support and customer satisfaction with the co-creation performance. Tourism Management, 33, pp. 1483-1492.

Ngo, L. V., O’Cass, A., 2013. Innovation and business success: The mediating role of customer participation. Journal of Business Research, 66(8), pp. 1134-1142.

Prahalad, C. K., Ramaswamy, V., 2004. The Future of Competition: Cocreating Unique Value with Customers. Boston MA: Harvard Business School Press.

Rodie, A. R. \& Kleine, S. S., 2000. Customer Participation in Services Production and Delivery (pp. 111125). In Swartz, T. A. \& Iacobucci, D. (Eds.), Handbook of Services Marketing and Management. Beverley Hills, California: Sage Publications, Inc.

Vargo, S. L., Lush, R. F., 2008. Service-Dominant Logic: Continuing the Evolution. Journal of the Academy of Marketing Science, 36, pp. 1-10. 


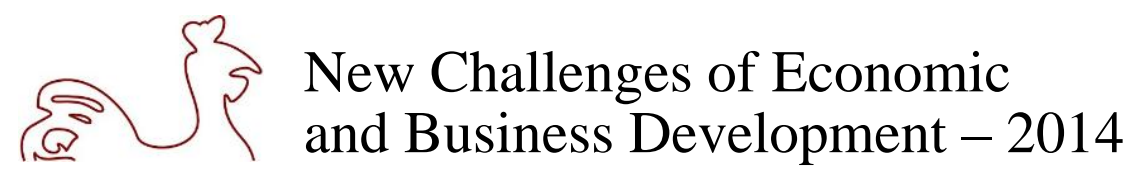

May 8 - 10, 2014, Riga, University of Latvia

\title{
HUMAN RESOURCE RECRUITMENT AND SELECTION APPROACHES IN PUBLIC SECTOR: CASE OF LATVIA
}

\author{
Inesa Voronchuk, University of Latvia ${ }^{74}$; \\ Olga Starineca, University of Latvia
}

Key words: Human Resource Recruitment and Selection, Public Sector

JEL codes: M51, Z18

\section{Introduction}

Human Resource (HR) recruitment and selection is an important process for any organisation. In terms of productivity and sustainability of the organisation, it is important to pay attention on potential employees, searching for necessary specialists and selecting the best suitable one for the organisation. HR recruitment and selection presumes several typical activities which should be realized, however, each organisation depending on its culture and vacant job positions creates its own framework and pipeline for HR recruitment and selection activities.

The issue 'unemployment amongst youth in Latvian and Europe in general' is relevant especially during economic recovering process. In our aging society and emigration tendencies, organisations should pay a lot of effort to reach the sustainable future. The situation on labour market makes to 'fight' for specialists. Based on previous pilot studies, it was defined that one part of young Latvian university students and graduates rather choose privet organisation to work for, another part is mostly interested on challenging job at high and well paid position whether in public or private sector.

In frame of socially responsible organisations it is useful to establish good relationships with potential employees, therefore organisation should lead HR recruitment process attractive for external environment as further on it can make easier the selection process between the most suitable responded candidates. HR selection is crucial edging point as it reflects on relationship creating with potential employees and employee branding maintenance through the external environment as well as organisations tasks and strategy fulfilment. The aim of the research is make introduction description of one of the HR selection activity - the first step of HR recruitment process - job advertisements creation in public sector. This analysis will show the main pros and cons of the chosen job advertisements development framework at Latvian public sector organisation. The research question is: "What kind of content do Latvian public sector organisations' job advertisements have?" The tasks of the study are: describe possible frameworks of HR recruitment and selection approaches; make the introduction analysis of the HR recruitment and selection process of the Latvian public sector organisations; identify the general public organisations' job advertisements; compare the profile of potential public sector employees and Latvian public sector organisations' requirement to the potential employees. The outcome of the research can be the ground for the further researches on the common topic.

\section{Methods and results}

The theoretical part of the study is based on monographic research method, when the historical theoretical bases of HR recruitment and selection approaches are identified and described; all observed approaches are compared. For the empirical study job advertisements with vacancies in general government were collected at the period of time from December $9^{\text {th }}$ till $10^{\text {th }} 2013$. In total there are 194 job advertisements, applied filter: "State and public administration" (CV-Online, 2013). Only 73 job

${ }^{74}$ Corresponding author - e-mail address: inesa.voroncuka@lu.lv, phone number: + 37129170333

Inesa Voronchuk, Olga Starineca 


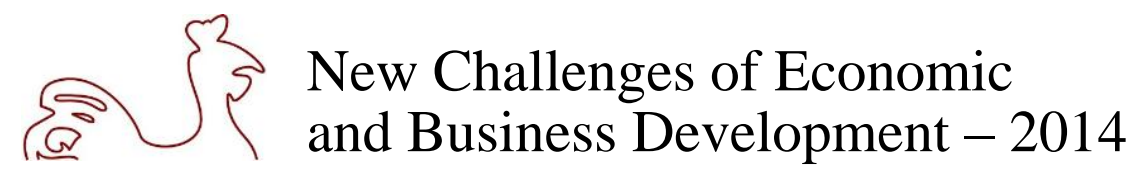

May 8 - 10, 2014, Riga, University of Latvia

advertisements on vacancies from fields like administration, finances and law were selected for the further analysis. Almost all selected job advertisements origin is the official publication "Latvian Journal". The biggest part of the advertisements could not be included; because they cannot be generalized (they are too specific). As the result the main requirements for the candidates were identified and analysed, the characteristic of the advertisements' structure was created. The sample error is taken into the account.

The rating of the most required qualification is created that shows the necessity of employees' skills, education and abilities to be able find job in public sector. Additionally statistical data is overviewed to describe the current situation on labour market.

To propose the method for the rational identification of requirements for the candidate designing the job advertisement authors describe Analytic Hierarchy Process (AHP) method (Saaty T.L., 1980). AHP method is based on rational decision making, evaluating the range of the alternatives by the criteria ranged by their importance (Asamoah D. et al., 2012). These preferences between alternatives are reached making pair-wise comparisons (Coyle G., 2004). The relative importance is determined using Saaty T.L. created nine point scale, where 1 - equal, 3 - moderate, 5 - strong, 7 - very strong, 9 - extreme level, 2, 4, 6 , and 8 - the intermediate values (Coyle G., 2004). Based on ranged criteria and alternatives the decision matrixes are created (Simões da Silva A.C. et al., 2010).

Other methods implemented: information synthesis and comparison; deduction and induction.

\section{Conclusions}

There are some legislative regulations, which should be taken into account recruiting and selecting several public sector staff and employees. The public sector job advertisement are publicly available at many job searching portals, however, the first publication is realized via the Latvian Journal and then they are automatically spread via others job searching WEB engines known in Latvia as well as one of the most popular among young specialists - www.cv.lv.

Public sector organisations use the typical standard form for job advertisement design, which has its own advantages and disadvantages discussed in the paper, e.g., Latvian public sector organisations' job advertisements are not specific or concrete enough. Young specialists on Latvian labour market prefer opposite that can be a cause of youth negative attraction to apply for the offered by public organisations vacancies.

The expectations and real situation on the labour market were compared and the possible case of professional match is described. This result of the analysis can be used afterwards by the public service organisation in case to improve the quality of the job advertisements design to attract more suitable candidates for the opened positions. This research is a part of the more spread research on HR recruitment and selection within public sector.

\section{Bibliography}

Simões da Silva, A.C., Belderrain, M.C.N. \& Pantoja, F.C.M. 2010. Prioritization of R\&D projects in the aerospace sector: AHP method with ratings. J. Aerosp.Technol. Manag., São José dos Campos, 2(3), pp. 339-348.

CV-Online, 2013. Applied filter: State and public administration. [Online] Available at: http://www.cv.lv/jobads/state-and-public-administration [Accessed 9 December 2013].

Asamoah, D., Annan, J. \& Nyarko, S. AHP Approach for Supplier Evaluation and Selection in a Pharmaceutical Manufacturing Firm in Ghana. International Journal of Business and Management, 7(10), pp. 49-62.

Coyle, G., 2004. Practical Strategy: The analytic hierarchy process (AHP). Glasgow: Pearson Education Limited.

Latvian Journal portal, 2013 About the Law and the State (Par likumu un valsti). [Online] Available at: http://www.lvportals.lv/amatu-konkursi.php [Accessed 9 December 2013].

Saaty, T.L., 1980. The Analytic Hierarchy Process: Planning priority setting. New York: McGraw-Hill. 


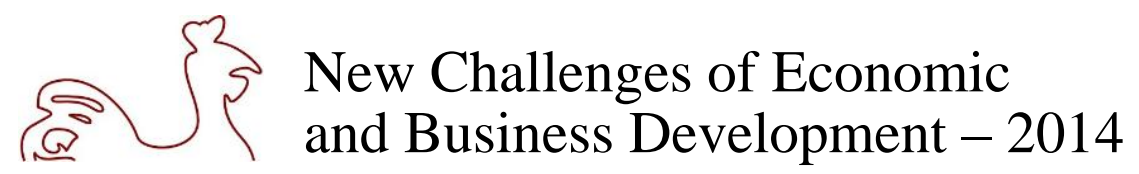

May 8 - 10, 2014, Riga, University of Latvia

\title{
THE HIGH QUALITY BUSINESS SCHOOL ACADEMIC TEACHER OF THE $21^{\text {ST }}$ CENTURY - POLISH STUDENTS' PERSPECTIVE
}

\author{
Małgorzata Wiśniewska, University of Gdańsk, Poland ${ }^{75}$; \\ Piotr Grudowski, Gdańsk University of Technology, Poland
}

Key words: quality, academic teacher, business school

JEL code: I2 1

\section{Introduction}

The managerial skills and knowledge are needed at initial stage of running an enterprise and also later during the development stage. The literature shows that the success and competence of future managers depend on the quality of their academic teachers (Chong S. \& Ho P., 2009). From that reason education at business schools is a demanding and complex task and therefore high quality study requires high quality lecturing/teaching that creates an environment in which deep learning outcomes are made possible for students (Villardi Q.B. \& Vergara S.C., 2013). It requires high-skilled and experienced academic staff who use innovative teaching methods, cooperate with business entities and properly prepare students to perform their managerial tasks. Regarding above and having in mind that some of the academic teachers' features like honesty, personal culture affect students attitudes (Payan J., Reardon J. \& McCorkle D.E., 2010), nor without the significance at business schools are: excellent manners of the teachers, diligence, having high requirements and the treatment of her or his profession with passion and commitment (Chepujnoska V., 2009). Based on this, it seems to be important, as the aim of the research, to identify the characteristics of the academic teacher working at business schools, according to the expectations of Polish students from a 21st century perspective.

\section{Methods and results}

A qualitative survey design was used, which is the most preferable and normally appropriate for studies that seek to gain an insight into the nature of a particular phenomenon (Chiresche R., 2011). A letter questionnaire was sent via e-portal (student-portal) to 144 second-year bachelor students of Gdańsk University, from the Faculty of Management, who were participants of an obligatory lecture titled "Quality management" (the first task of the research). They were asked to list a maximum of five, most preferred characteristics of a high quality business school academic teacher of the 21 st century. The question was: what should a high quality business school academic teacher of the 21 st century be like? Finally, 109 students participated in the study, and 471 characteristics were proposed. The proposals were analysed by listing all the features identified by the respondents (the second task). They were put into five categories proposed by A. Parasuraman, V.A. Zeithaml and L.L. Berry (1988), as follows: tangibles (T), reliability (Rel), responsiveness (Res), assurance (A) and empathy (E) (the third task), and were listed in a descending order (the fifth task). The Pareto-Lorenzo analysis was used to select those with a higher impact on the quality of teaching, according to the 80-20 rule (Oakland J.S., 1989) (the sixth task). Based on that the conclusions were presented (seventh task).

\footnotetext{
${ }^{75}$ Corresponding author - e-mail address: wis@wzr.pl; malwis1709@wp.pl, phone number: +48 607082166; The work is financed from the National Center of Science Fund: NCN OPUS 4/ No 2012/07/B/HS4/02929.
} 


\section{$\left\{\begin{array}{l}3 \\ 5\end{array}\right.$ New Challenges of Economic and Business Development - 2014}

May 8 - 10, 2014, Riga, University of Latvia

\section{Conclusions}

The quality of a business school academic teacher affects managerial skills and attitudes. It is multidimensional and depends on a number of characteristics (Wiśniewska M., 2007; Grudowski P., 2011). Among the hard characteristics of the business school academic teacher assurance, responsiveness and reliability seem to be the most important from the perspective of the students' needs. They expect from the academic teacher to be well prepared, to teach in an interesting and in a full of passion way. Very important are modern techniques and teaching methods used during teaching and communicating with students, like e-learning, webinars, e-conferences, simulation exercises, real case studies based on current experience of Polish companies and on success stories, meeting with top managers, with company owners, visiting companies and gamifications (using management games). Students want to cooperate with and learn from well-skilled teachers, willing to learn, open to new ways of teaching, and see them as advisors. Most preferable are teachers who collaborate with business environment as consultants or auditors or are simply real managers. It means that Polish business schools students need well educated, creative teachers with authority based on their professional knowledge and practical experience. In that case the crucial factor seems to be a very close and active cooperation of business management faculties at universities and/or business schools with regional business councils, companies representatives and with the representatives of future employers.

\section{Bibliography}

Chepujnoska, V., 2009. Quality Management - Theory, Science and Practice. Skopje: Faculty of Metallurgy Publishers Inc.

Grudowski, P., 2011. Quality Assurance of Educational Processes as the Foundation of the Quality Management System in Gdansk University of Technology, in: Jarke, Ph., (ed.) Bildungspolitische Strategien Heute und Morgen Rund um das Mare (pp. 393-403). Hamburg : Baltic Sea Academy.

Chong, S. \& Ho, P., 2009. Quality teaching and learning: a quality assurance framework for initial teacher preparation programmes, International Journal of Management in Education, 3(3/4), pp. 302-314.

Oakland, J.S., 1993. Total Quality Management. Oxford: Butterworth-Heinemann Ltd.

Parasuraman, A., Zeithaml, V.A. \& Berry, L.L., 1988. Servqual: A Multiple Item Scale For Measuring Consumer Perception of Service Quality, Journal of Retailing, 64(1), pp. 12-37.

Payan, J., Reardon, J. \& McCorkle, D.E., 2010. The Effect of Culture on the Academic Honesty of Marketing and Business Students, Journal of Marketing Education, December (32), pp. 275-291

Wiśniewska, M., 2007. Total Quality Education w szkolnictwie wyższym. Próba definicji i proces wdrożenia, Problemy Jakości (in Polish), 9, pp. 13-22.

Villardi, B.Q. \& Vergara, S.C., 2013. How do business school professors learn to teach management students? Learning and pedagogical assumptions guiding practice. The 2013 Organizational Learning, Knowledge and Capabilities conference (OLKC). Theme: Translation, Transition \& Transmission, Washington, April 25-27. [Online] Available at: http://www.olkc2013.com/sites/www.olkc2013.com/ files/downloads/175.pdf [Accessed 10 December 2013]. 
May 8 - 10, 2014, Riga, University of Latvia

\title{
INTERNATIONAL JOINT VENTURE PERFORMANCE MEASUREMENT AND DEVELOPMENT STRATEGY IN CHINA - AN EXPLORATORY STUDY OF SINO-SWEDISH JOINT VENTURES
}

\author{
Hanjun Yin, Sydney Institute of Language and Commerce, \\ Shanghai University, People's Republic of China ${ }^{76}$; \\ Xiaosong Zheng, School of Economics and Business Administration, \\ Tallinn University of Technology, Estonia
}

Key words: international joint venture, performance, strategy, development, Sino-Swedish

JEL code: M16, M31

\section{Extended abstract}

In the context of global economic integration, international joint ventures (IJVs) have emerged and developed rapidly in the world. Since the reform and opening up, China has attracted a substantial amount of foreign direct investments (FDI) from other countries. One of most preferred ways to enter the Chinese market is IJVs. However, IJVs encounter a lot of problems in recent years, which lead to a high rate of failure. An increasing attention has been paid to the performance and development strategy of IJVs. Dynamic capabilities are the ability to sustain firms' competitive advantages by seizing opportunities, while finding some changes in the market and transforming its existing resources and competencies. In this paper we review existing research on dynamic capabilities and use this theory to do a detailed case study on one Sino-Swedish joint venture operating in Mainland China, describing that how dynamic capabilities influence IJV's performance and help managers formulate and implement competitive strategies.

\section{Introduction}

International Joint venture (IJV) is organized by two or more legally distinctive and mutually dependent parties from different countries. Scholars and managers want to find a proper strategy to sustain advantages and extend the life of IJVs in fiercely competitive global markets. In the last decade, an increasing number of scholars believe that dynamic capabilities are at the heart of firm strategy, value creation and competitive advantage (e.g. Teece et al., 1997; Eisenhardt and Martin, 2000; Winter, 2003, Teece, 2007, Helfat et al. 2007). So in this research we carefully study dynamic capabilities theory to solve IJV issues. Nowadays, Nordic countries are optimistic about the Chinese market and they consider that the competition in China is getting tougher. We take one of Sino-Swedish joint ventures called Shandong Lingong Construction Machinery Co. Ltd (SDLG) as a case study, and make a detailed analysis of its dynamic capabilities and sustainable competitive advantages. The results can be applied not only on Sino-Swedish JVs but also on other IJVs' decision making.

\section{Methods and results}

We use Yin's exploratory theory method; this study is based on existing theories such as dynamic capabilities to do a case study that explores the performance and development strategy of IJVs. We

\footnotetext{
${ }^{76}$ Corresponding author - e-mail address: littlepine88@163.com, phone number: +861 8888738636
} 


\section{$2\left\{\begin{array}{l}3 \\ 5\end{array}\right.$ New Challenges of Economic and Business Development - 2014}

May 8 - 10, 2014, Riga, University of Latvia

analyse data collected from VOLVO CE and Shandong Lingong Construction Machinery Co. Ltd (SDLG). We carefully study Chinese construction machinery industry, and why VOLVO and SDLG can do a good job of collaboration. We recognize their internal and external environment, their strength and weakness, and their effort to get out of trouble. When there is a performance gap or an opportunity gap in a firm, managers of this company is required to have strategic insights of assessing opportunities and threats, and strategic execution to build the capabilities to deliver market results. We advanced dynamic capabilities framework which seems a most innovative and comprehensive approach to analyze modern corporation. The aim of this paper is to make proper development strategies, increase firm's sales volume, and achieve better performance, sustain organization's survival.

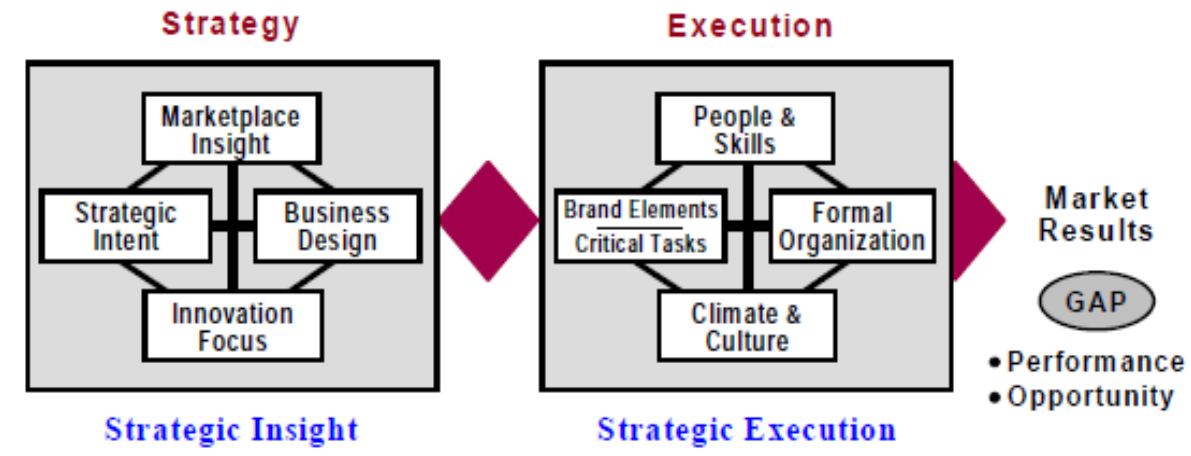

Fig. 1. The Business Leadership Model (Michael and Tushman, 2006)

\section{Conclusions}

To sum up, dynamic capabilities is not an abstract and unrealistic theory but a useful and practical set of mechanism, which can assist managers in development of competitive strategies and solving critical problems. In recent years, IJVs have met a lot of challenges and threats, such as trust, culture, control and satisfaction. Many managers fail to adapt to this rapidly changing world and give proper responses timely. Therefore, many IJVs divorce quickly. Different from prior strategic management theories, such as Michael Porter's "Five Forces", the resource-based view of strategy, strategic conflict approach, the recent promising theory of dynamic capabilities is aimed to build and adjust firms' competencies to successfully sustain their performance while external environment is changing rapidly. Managers of SDLG should sense the change of marketplace and seize the opportunities to keep its competitive advantage. SDLG can learn from the leadership model, it is an integrated method to pay close attention to both the formulation and execution of strategies. Apart from SDLG, IJVs in China even all over the world can be benefited by dynamic capabilities theory.

\section{Bibliography}

Charles, A. O’R. III \& Tushman, M.L., 2006. Dynamic Capabilities at IBM: Driving Strategy into Action. Teece, D., 2011. Dynamic Capabilities: A Framework for Profitability. Ivey Business Journal. Wilson, J. \& Brennan, R., 2008. Relational factors in UK-Chinese international joint ventures.

Lu, L.T., 2008. Measuring Performance of Sino-Japanese Joint Ventures in China: The Relationship among Methods, Parties, Approaches, and Impact of National Culture. Department of Management, Fo Guang University, Taiwan. 


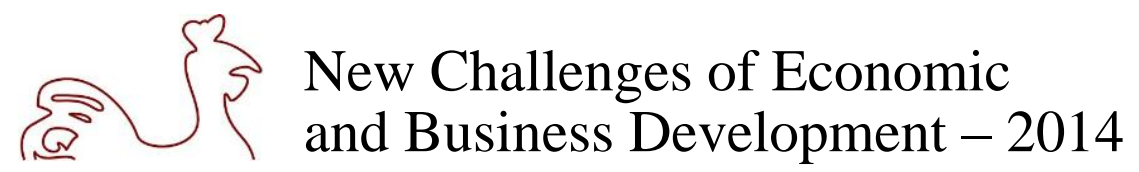

May 8 - 10, 2014, Riga, University of Latvia

\title{
PERSPECTIVES ON GOVERNMENTAL MANAGEMENT ACCOUNTING IN CHINA
}

\author{
Xiaosong Zheng, Tallinn University of Technology, Estonia ${ }^{77}$; \\ Jaan Alver, Tallinn University of Technology, Estonia
}

Key words: government, GMA, limitation, function, China

JEL codes: M41, M48

\section{Extended abstract}

Governmental management accounting (GMA) is a less studied area in the literature because of its complexity and close dependence on national legislations and policies. This is particularly true for emerging markets such as China. This paper studies the current GMA practices in China. It first introduces the concept, roles and functions of GMA and its applications in China. Then through case studies it presents and discusses the various problems and limitations in the implementation of GMA in China at the local government level. A focus is laid on discussion of values and accountability in the application of GMA. It is found that insufficient recognition of the GMA value, inadequate knowledge and skills of GMA and dependence on national legislations and policies are the main obstacles in the implementation of GMA in China. At the end of the paper conclusions are made and suggestions for further development of GMA in China are also listed and discussed.

\section{Introduction}

Governmental Management Accounting (GMA), whose main users are various government departments or other non-profit organizations, aims at supervising and utilizing public resources (Chan et al., 2001; Zhang, 2009). As a power-concentrated bureaucratic organization, government allocates diverse resources on behalf of the public. However, most of government financial activities are closely tied to taxpayers who are unable to constrain actions of government. This reveals that government activities are not under the regulation and control of the market mechanism (Wang, 2004; Duh et al., 2008; Wei, 2009; Wang and Wang, 2012). Guo (2008) points out that the function of government is to provide public goods and services with the principle that it has to fulfil public demands.

With regard to public economics, public fiscal resource is public fiduciary duty of a government. GMA can allocate its objectivities and resources to every financial activity, supervising fiscal practices and effectively disposing fiscal resources through the control of activities, planning, cost analysis and performance evaluation ( $\mathrm{Lu}$ et al., 2007). In view of public management, the function of GMA is to heighten the level of decision-making in public fiscal managerial activities, guide relevant decisionmaking process, and help making decisions on the basis of management decision system and market mechanism and objective evaluation of performances. From accounting perspective it is urgent for the government to improve the government fiscal accounting, zealously construct their own GMA system and make an organic union of management and financial accounting.

The paper then introduces GMA. After this research method is described. The next section presents the current practices of GMA in China. A case study is then presented and discussed. Based on the

${ }^{77}$ Corresponding author - e-mail address: xiaosong.zheng@ @tu.ee, phone number: +372 6204032 


\section{$\left\{\begin{array}{l}3 \\ 5\end{array}\right.$ New Challenges of Economic and Business Development - 2014}

May 8 - 10, 2014, Riga, University of Latvia

discussion advices on further development of GMA in China are given. Conclusions are made in the last section together with suggestions for future research directions on GMA in China.

\section{Methods and results}

In this research I will use case study research method as described by Yin (2003). Semi-structured interviews (Rubin and Rubin, 1995) are also used to collect data. In case study a common difficulty is to generalize results (Yin, 2003). One solution is to use analytical generalization in the same way as in case studies in general (Yin 2003). In this research I also followed the analytical generalization for discussions and results from the case study.

\section{Conclusions}

Chinese legislations and policies can pose some threats on GMA under some circumstances. An obvious case is that Chinese Budget Law split up the relationship of budget and accounting. Affected by the law, GMA loses some practical meaning. In addition, Audit Law in China focuses on financial revenue and expenditure while neglects cost and performance of activities. This emphasis makes GMA lack certain legal guarantee. Besides, imperfectness of budget system also hinders the application of GMA. In terms of financial structure, Chinese management of public finance is relatively chaotic. For instance, ambiguous responsibility system usually causes different systems to work simultaneously and requires management from different departments. It is inevitable that some people may grasp the chance to pursue personal benefits.

In China there are still many problems in the application and implementation of GMA. Innovative suggestions and solutions need to be developed to address these problems. In the paper a number of such suggestions and solutions are listed and discussed at the end of the paper.

\section{Bibliography}

Chan, J. L., Cong, S. \& Zhao, J., 2001. The Effects of Reform on China's Public Budgeting and Accounting System. International Comparative Issues in Government Accounting. US: SpringerVerlag. Part IV.

Duh, R., Xiao, J. Z. \& Chow, C. W., 2008. An Overview and Assessment of Contemporary Management Accounting Research in China. Journal of Management Accounting Research, 20, pp. 129-164.

Guo, L., 2008. Theories and Practices of Governmental Management Accounting. Beijing: The Financial and Economic Publishing House.

Rubin, H. J. \& Rubin, I. S., 1995. Qualitative Interviewing: The Art of Hearing Data. Thousand Oaks: Sage Publications.

Wang, G., 2004. The Fiduciary Management Responsibilities and Management Audit. Beijing: China Modern Economic Publishing House.

Wang, F. \& Wang, P., 2012. Ownership Structure and Accounting Conservatism in China. Journal of International Accounting, Auditing \& Taxation, June 2012, 21(1), pp. 1-16.

Wei, L., 2009. Governmental Influences in the Development of Chinese Accounting During the Modern Era. Accounting, Business \& Financial History, November 2009, 19(3), pp. 305-326.

Yin, R. K., 2003. Case Study Research: Design and Methods. Thousand Oaks, Cal.: Sage Publications.

Zhang, Z., 2008. The Application of Cost Management Accounting in Government. Accounting and Finance, May 2009, 65(5), pp. 22-29. 


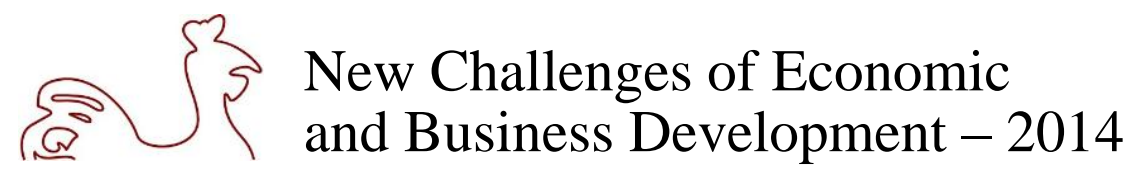

May 8 - 10, 2014, Riga, University of Latvia

\title{
MARKET DYNAMICS IN CONSUMER SEGMENTATION: MODELLING FRAMEWORK
}

\author{
Anna Zhigalova, University of Latvia, Latvia ${ }^{78}$
}

Key words: market segmentation, trends, consumer heterogeneity

JEL codes: M31, A14, M30

\section{Introduction}

The concept of consumer segmentation have been widely used by social scientists to explain a variety of behavioural phenomena, such as leisure choices (Koc at al., 2007), price sensitiveness (Murthi et al. 2012), food choices (Onwezen et al. 2012, Visschers et al. 2013), differences in consumption by generation (Valentine at al. 2013), store choices (Han, 2014), and so on. In market segmentation, one distinguishes homogeneous groups of customers who can be targeted in the same manner because they have similar needs and preferences. Anywhere in between two extremes of one-to-one marketing and mass marketing lies the identification and targeting of segments. In the past couple of years, many attempts were made to elaborate reliable segmentation concepts, where the relative stability of values is one of its attractive features for market segmentation. However, the influence of marketing environment factors is underestimated for now. Problem considered for this research: besides discussed limitations, there is no segmentation that considers consumption dynamics or outlines demand forecast, market trends do not influence the model. Aim of this research was to define what trends influence further demand and how they could be integrated into the new model of consumer segmentation, considering psychographic and demographic data and providing reliable demand forecast. Tasks of the research are: identify what external drivers and to what extent influence shaping and modification of consumer segments; determine the importance and level of uncertainty of each driver in relation to their overall impact; map the interdependencies between all of the prioritised drivers, examining the extent to which each driver impacts on the other drivers; analyse examined all of the interrelationships between the prioritised drivers; determine which drivers were most dominant in terms of their impact on future change, and which drivers were more dependent on. Prior segmentation studies have been static in identifying consumer groups. One of the greatest challenges for developing more successful marketing strategies is gaining an understanding of the diversity of trends that influence the consumer behaviour. The current study aims to identify meaningful segments on the basis of the importance of current consumption trends in food and drink industry and their influence level.

\section{Methods and results}

Method - existing literature review focused on latest research done in the field supported by empirical qualitative research using in-depth interviews with industry experts with further prioritization of drivers determining the importance and level of uncertainty of each driver. Following analysis done to map the interdependencies between all of the prioritised drivers, examining the extent to which each driver impacts other drivers. The analysis examined all of the interrelationships between the prioritised drivers and allowed to determine which drivers were most dominant in terms of their impact on future change, and which drivers were more dependent on. The emergent driver clusters were identified as shown in Table 1.

The result of this analysis is summarised in a matrix that identifies dominant drivers versus dependant and represents the relative importance and uncertainty of them. This analysis allows arranging the drivers into four clusters to form a base for the new model of consumer segmentation, what was supported during the workshop discussion with industry stakeholders. A qualitative survey was carried out by author in Latvia by conducting

${ }^{78}$ Corresponding author - e-mail address: anna.zhigalova@ gmail.com, phone number: +37129548343

Anna Zhigalova 


\section{$\left\{\begin{array}{l}\left\{\begin{array}{l}\text { New Challenges of Economic } \\ \text { and Business Development }-2014\end{array}\right.\end{array}\right.$}

May 8 - 10, 2014, Riga, University of Latvia

in-depth interviews with the industry experts. New segmentation have been identified to be used in further consumer research which results could be used to work out recommendations for the industry to improve understanding of the future by identifying ways in which the market is likely to change, and outlining how to mitigate the potential risks and also capitalise on the exciting opportunities that the future holds.

Driver Clusters

Table 1

\begin{tabular}{|l|l|}
\hline Motivation for Consumption & Attitudes Towards Consumption \\
\hline Health Awareness & Market Environment and Structure Shift \\
\hline Entertainment Society & Social Responsibility \\
\hline Informed Connoisseur Consumer & Income Shift \\
\hline Digital World & Personalization \\
\hline
\end{tabular}

Source: author's grouping based on cluster analysis, November and December 2013.

\section{Conclusions}

A framework for dynamic segmentation was proposed based on the research results and a first empirical illustration was offered. Two major clusters that may impact consumer choices identified and which may influence segmentation results. Research results let to identify the combination of key areas that are important for the industry, as well as capturing the critical strategic uncertainties. Each of the clusters identified formed the basis for one of the axes of that was subsequently developed. The axes are designed to reflect the output of the importance versus uncertainty matrix as well as to be different in nature to each other, avoiding the risk to 'collapse' on top of each other and therefore produce only a relatively narrow range of possible futures for the forecast, juxtaposed to create four possible segments representing how the market could develop. The segments are designed to be provocative and to reconsider existing assumptions about the future demand which will also depend both on decisions within industry's control and external forces and drivers outside industry's direct or indirect influence. The study demonstrates that accounting for change in the consumer segments is possible and important. More research, however, is needed to understand the forces powering the change. Practical implication is in the further research of consumption within the segments based on money and time spent. Segmentation results can be used as input for long-term strategies or else reapplied across time when new strategies regarding segmented markets have to be developed. As these questions are highly relevant for marketing management, it seems appropriate to change the practice of segmentation. An emphasis is put on the dynamic perspective of segmentation. The temporal structure of decisions concerning entrance or exit could be improved. The concept of segmentation is linked to the market process. The interdependencies of segmentation become more obvious. Further extensions of the proposed modelling framework and available data may show more detailed dynamics of consumers' segments.

\section{Bibliography}

Han S., Ye Y., Fu X., Chen Z., 2014, Category Role Aided Market Segmentation Approach to Convenience Store Chain Category Management, Decision Support Systems 57, pp. 296-308.

Koc E., Altinay G., 2007. An Analysis of Seasonality in Monthly per Person Tourist Spending in Turkish Inbound Tourism from a Market Segmentation Perspective, Tourism Management, 28, pp. 227-237.

Murthi B., Rao R., 2012. Price Awareness and Consumers' Use of Deals in Brand Choice, Journal of Retailing 88(1), pp. 34-46.

Onwezen M., Reinders M., van der Lans I., Sijtsema S., Jasiulewicz A., Dolors Guardia M., Guerrero L., 2012. A Cross-National Consumer Segmentation Based on Food Benefits: The Link with Consumption Situations and Food Perceptions, Food Quality and Preference, 24(2), pp. 276-286.

Valentine D., Powers T., 2013, Generation Y Values and Lifestyle Segments, Journal of Consumer Marketing, 30(7), pp. 597-606.

Visschers V., Hartmann C., Leins-Hess R., Dohle S., Siegrist M., 2013, A Consumer Segmentation of Nutrition Information use and its Relation to Food Consumption Behaviour, Food Policy, 42, pp. 71-80. 


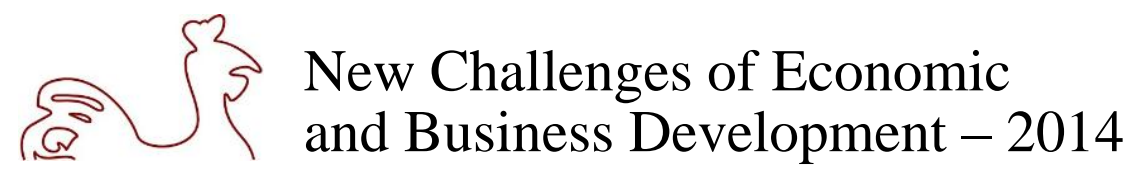

May 8 - 10, 2014, Riga, University of Latvia

\title{
THE IMPACT OF SOCIOECONOMIC REFORMS ON THE WORK INCENTIVES IN LATVIA
}

\begin{abstract}
Anna Ždanoviča, University of Latvia, Latvia ${ }^{79}$
Key words: work incentives, income distribution, tax-benefit system, EUROMOD microsimulation model

JEL codes: C15, H24, H31

\section{Introduction}

At the international and national levels, the influence of tax and benefit policy on the individual`s decision about how much time spend working is a determinative aspect in the design of public policies. Understanding labour supply behaviour is thus crucial for socioeconomic reform to invoke work incentives. Several Personal Income Tax reforms, came into force since January 2014. In 2014, it is expected to develop a proposal of making non-taxable minimum progressive. Another possible scenario of implementation of the progressivity is introduction of a higher rate income tax band. Using the European Union tax-benefit microsimulation model (EUROMOD), and the European Union Statistics on Income and Living Conditions (EU-SILC) survey microdata, this paper identifies the impact of the proposed and alternative socioeconomic reforms on changes in work incentives in Latvia. In particular, this paper aims at the role of Personal Income Tax (PIT) and basic PIT in influencing Marginal Effective Tax Rates. Higher rate of labour taxes and existence of means-tested benefits are expected to lower work incentives of high - income individuals, but have little effect on the lowincome individuals. This paper compares the distribution of METRs by deciles of disposable equivalised income under the reforms. Estimates of the impact of selected reforms of taxes and benefits on the work incentives of Latvia's population allow to determine the socioeconomic reforms which increase work incentives in the country.
\end{abstract}

\section{Methods and Results}

\section{Methodology}

EUROMOD is a tax-benefit microsimulation model for the European Union that enables researchers and policy analysts to calculate, in a comparable manner, the effects of taxes and benefits on household incomes and work incentives for the population of each EU country and for the EU as a whole (University of Essex, 2014). Individual and household tax liabilities and benefits entitlements are simulated under the existing policy rules in Member State and in Latvia in particular.

Along with calculating the effects of actual policies, EUROMOD is also used to evaluate the effects of tax-benefit policy reforms on changes of poverty rates, income inequality, work incentives and government budgets (University of Essex, 2014) and to simulate the effects of proposed, alternative or hypothetical policy changes, as well as for exploring the implications of alternative economic or demographic scenarios at national and EU levels (Sutherland H. \& Figari F., 2013).

The results presented in this report are derived using EUROMOD version F6.36+.

${ }^{79}$ Corresponding author - e-mail address: anna.zhdanovich@ inbox.lv, phone number: +371 27759889 


\section{\{ $\{$ New Challenges of Economic and Business Development - 2014}

May 8 - 10, 2014, Riga, University of Latvia

\section{Input data}

Most of EUROMOD input data are derived from the European Union Statistics on Income and Living Conditions (EU-SILC) data as released by Eurostat. Calculations are based on EU-SILC 2010 data (2009 year incomes). The data is not adjusted for labour market and demographic changes that took place over this period, therefore the changes in METRs between scenarios reflect the changes in tax-benefit systems, controlling for changes in METRs that occurred because of changes in economic situation or composition of the population.

\section{Measuring financial work incentives}

An individual's financial incentive to work will depend on the relationship between hours of paid work and net income, taking account of the financial costs of working and not working (Berger F., 2010). 'Net income' means income after benefits and tax credits have been added and after direct taxes have been deducted. Therefore, tax-benefit systems play a primary role in influencing work incentives (Jara \& Tumino, 2013).

The incentives for those already in work to work harder or earn more is measured by the Marginal Effective Tax Rates (METRs), i.e. the share of additional income that would be taxed away because of taxes, social insurance contribution and benefit withdrawal (Jara \& Tumino, 2013). As with the incentive to work versus not working, low numbers mean stronger financial incentives. An EMTR of zero means that the individual keeps all of any small change in earnings, and a rate of 1 means that the individual keeps none (Adam S. et al, 2006).

In this paper, the analysis of work incentives concentrates on the METRs to compare work incentives created by social economic reforms in Latvia. In previously published works (e.g. Jara \& Tumino, 2013) the changes in average METRs between 2007 and 2010 are analysed for the 27 EU countries for all population. This paper will divide all population by the deciles of equivalised disposable income, and the Distribution of METRs by deciles of disposable equivalised income under the reforms will be compared.

\section{Conclusions}

The paper results allow to make conclusions about the effects of change of taxes and benefits on the work incentives of Latvia's population and to determine the socioeconomic reforms needed to increase work incentives in the country. The results of the paper can be used in the the design of public policies.

\section{Bibliography}

University of Essex, 2014. EUROMOD: Tax-Benefit Microsimulation Model for the European Union. [Online] Available at: https://www.iser.essex.ac.uk/euromod [Accessed 4 January 2014].

Adam, S., Brewer, M. \& Shephard, A., 2006. The poverty trade-off. Work incentives and income redistribution in Britain. Institute for Fiscal Studies.

Berger, F., Islam, N. \& Liégeois, P., 2010. Discrete Choice Modelling of Labour Supply in Luxembourg Through EUROMOD Microsimulation. EUROMOD Working Paper No. EM5/10, pp. 1-36.

Sutherland H. \& Figari F., 2013. EUROMOD: the European Union tax-benefit microsimulation model. International Journal of Microsimulation, 6(1) 4-26, pp. 1-23.

Jara X. \& Tumino A., 2013. Tax-benefit systems, income distribution and work incentives in the European Union. EUROMOD Working Papers EM7/13, EUROMOD at the Institute for Social and Economic Research. 